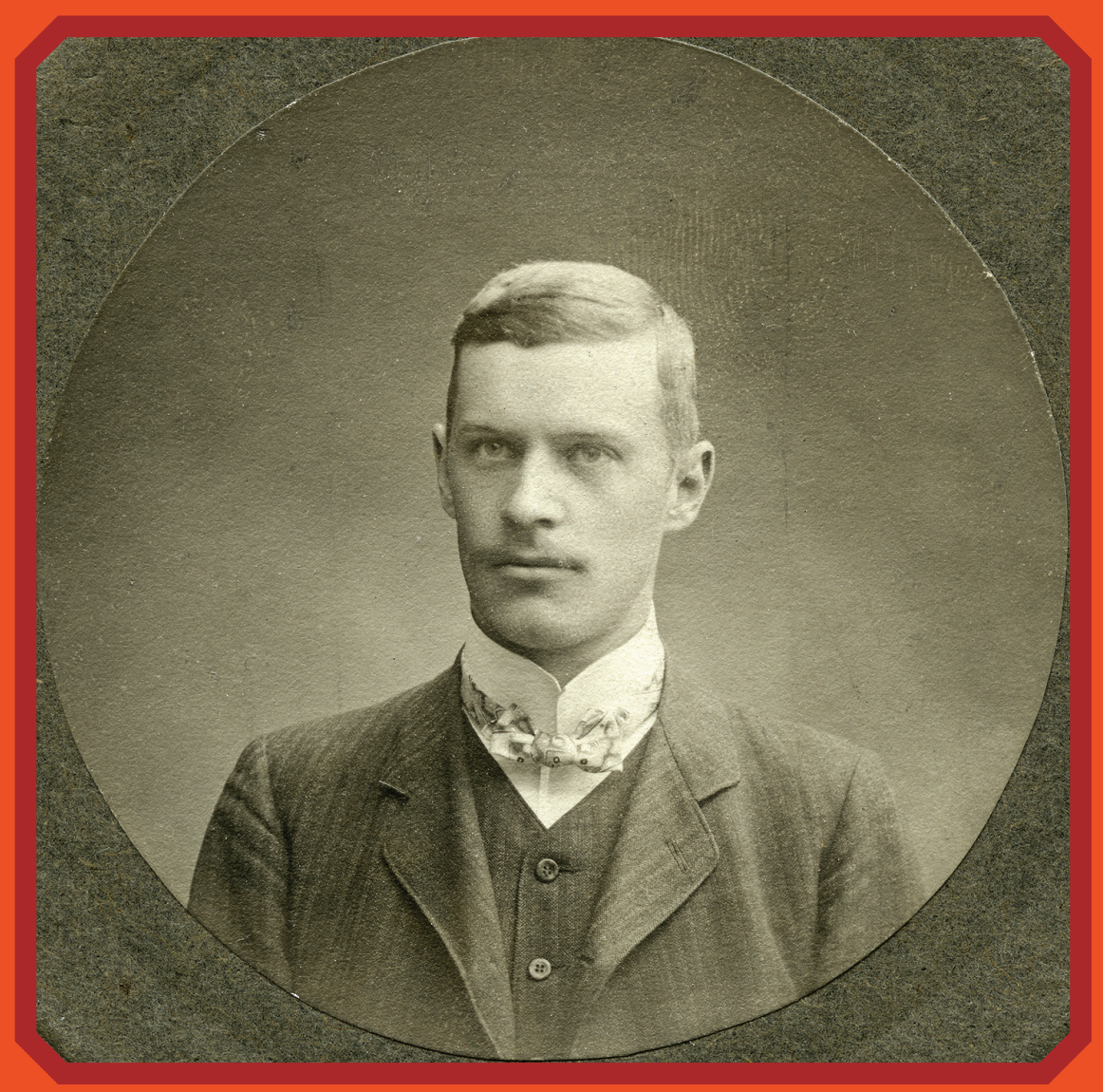

\title{
Petri Jussila
}

\section{Tlianstomies torpparicn asialla}

Edvard Gyllingin maatalouspolitttinen ajattelu ja toiminta suurlakon ja sisällissodan välissä 
Tilastomies torpparien asialla 



\section{Petri Jussila}

\section{Tilastomies torpparien asialla}

Edvard Gyllingin maatalouspoliittinen ajattelu ja toiminta suurlakon ja sisällissodan välissä

Suomen historian väitöskirja

Esitetään Jyväskylän yliopiston humanistisen tiedekunnan suostumuksella julkisesti tarkastettavaksi yliopisto Historicarakennuksen salissa H 320 helmikuun 27. päivänä 2015 kello 12. 
Työväen historian ja perinteen tutkimuksen seura 2015

(C) Petri Jussila

Taitto ja kansi: Raimo Parikka

Kannen kuva: Edvard Gylling, Työväen Arkisto.

ISBN 978-952-5976-32-8 (nid.)

ISBN 978-952-5976-33-5 (PDF)

Hansaprint, Vantaa 2015 


\section{SISÄLLYS}

$\begin{array}{ll}\text { Esipuhe } & \ldots 7\end{array}$

1. Johdanto $\quad$... 10

Suomen maatalouskysymys 1900-luvun alussa $\quad \ldots 10$

Sosialidemokraattien vaikea suhde maatalouden

kehitykseen $\quad \ldots 14$

Kuka oli Edvard Gylling? $\quad$... 16

Aikaisempi tutkimus $\quad$...21

Kysymyksenasettelu ja sen rajaukset $\quad$... 29

Tärkeimmät alkuperäislähteet $\quad$... 32

Metodologia $\quad \ldots 34$

2. Tie tutkijaksi $\quad \ldots 43$

Ajattelun taustatekijät $\quad \ldots 43$

Historiallisen kansantaloustieteen merkitys $\quad$... 52

Tutkielma maatyöväestön oloista $\quad \ldots 58$

Laajan tilastollisen selvityksen johtajana $\quad$... 64

3. Tie poliittiseksi vaikuttajaksi $\quad$...69

Sosiaalireformismia ja sosialismia $\quad$...69

Suurlakon radikalisoiva vaikutus $\quad \ldots 79$

Poliittisen vaikuttamisen ensiaskeleet $\quad \ldots 86$

4. Sosialidemokraattien maatalouspolitiikan asiantuntija $\quad$...99

Kautskylaisuus vai revisionismi? $\quad$...94

SDP:n viljelyspakkovaatimus $\quad$... 104

Kirjoituksia maatalouden kysymyksistä $\quad \ldots 113$

SDP:n maatalousohjelman puolustajana $\quad$... 119

Kansanedustajaksi $\quad \ldots 131$

Väitöskirja torpparilaitoksen historiasta $\quad \ldots 137$ 
5. Sosialidemokraattien maatalouspolitiikan linjanvetäjä $\quad$... 152

Uuden maanvuokralain hyväksyminen $\quad$... 152

Torpparit on itsenäistettävä! $\quad$... 164

Maatalouskysymysten ratkaisuyrityksiä valtiopäivillä $\quad \ldots 178$

6. Yhteiskunnallisten aineiden ja historian opettaja $\quad$... 195

Puolueopiston luennot historiakuvan avaajana $\quad$... 195

Tutkimustyö yhteiskunnallisen näkemyksen

syventäjänä

... 208

7. Maatalouspoliitikko vaikeissa oloissa $\quad$... 226

Torpparikysymys vuoden 1916 valtiopäivillä _.. 226

Torpparien asialla vallankumouksien keskellä _ ...230

Katse taaksepäin: myöhempi tulkinta

sosialidemokraattisesta maatalouspolitiikasta

... 245

8. Edvard Gylling maatalouspoliitikkona suurlakon ja sisällissodan välisenä aikana

Summary

... 259

Lähteet

... 265 


\section{Esipuhe}

Tämän väitöskirjan tekeminen on ollut pitkä prosessi. Kiinnostukseni historiaan syntyi jo lapsena, kun kuuntelin isoisäni tarinoita hänen nuoruudestaan ja keskustelin isäni kanssa menneisyyden tapahtumista ja tulkinnoista. Ensimmäisten kouluvuosien aikana luinkin sarjakuvien ja romaanien lisäksi myös marxilaisuuden klassikoita ja erityisesti Suomen historiasta kertovia tutkimuksia. Lukion jälkeen hakeuduin opiskelemaan historiaa Jyväskylän yliopistoon, jossa viihdyin erinomaisesti. Opiskelun painopiste siirtyi viimeinkin asioiden ulkoa opettelusta pyrkimykseen ymmärtää niitä. Historian laitoksen ilmapiiri oli hyvä, kannustava ja innostava.

Pitkään ajattelin alkavani historiantutkijan uralle, mutta sitten päätin alkaa EU-projektien suunnittelijaksi ja vetäjäksi, joita tuolloin tarvittiin yhä enemmän. Työurani olenkin tehnyt lähinnä erilaisten kulttuuriin, hyvinvointiin ja työelämään liittyvien tutkimus- ja kehittämishankkeiden parissa. Historianopiskelusta ei ole näissä tehtävissä välitöntä ja suoraa hyötyä, mutta sen antama laaja yleissivistys ja yhteiskunnallisen muutoksen ymmärtäminen on ollut erinomainen lähtökohta myös tällaisiin tehtäviin.

Jyväskylän yliopistolla olin lähes kahdeksan vuotta, tuloksena filosofian lisensiaatin tutkinto, johon sisältyi historian lisäksi myös filosofiaa ja yhteiskuntatieteitä. Vuonna 1998 valmistuneen lisensiaatintyöni aihe oli "Edvard Gylling ja maatalouskysymys 1900-luvun alun Suomessa". Tämän kiinnostavan aiheen sain silloiselta Suomen historian professori Toivo Nygårdilta, jota haluan kiittää lisensiaatintyöni erittäin asiantuntevasta ohjauksesta. Kiitokseni ansaitsevat myös lisensiaatintyöni tarkastajat, professori Raimo Salokangas ja dosentti Anssi Halmesvirta, joiden lausunnot osaltaan ohjasivat minua oikeaan suuntaan väitöskirjassani. 
Väitöskirjan työstämisen aloitin toden teolla vasta kymmenkunta vuotta lisensiaatintyön valmistumisen jälkeen. Lisensiaatintyö toimi väitöskirjankin aiheen pohjana, mutta tein sen kysymyksenasetteluun, aikarajaukseen ja menetelmiin varsin suuria muutoksia. Tässä sain tukea ohjaajiltani, professori Pirjo Markkolalta ja professori Petri Karoselta. Varsinkin professori Markkolan kanssa käymäni useat antoisat keskustelut ovat auttaneet minua jäsentämään aiempaa paremmin tutkimuksen kysymyksenasettelua, tutkimusmenetelmiä ja rakennetta. Väitöskirjani esitarkastajina toimivat professori Sakari Heikkinen Helsingin yliopistosta ja akademilektor Ann-Catrin Östman Åbo Akademista, joiden lausuntojen pohjalta sain hyviä huomioita ja ehdotuksia työni viimeistelyyn. Haluan kiittää jokaista näistä historian asiantuntijasta heidän osuudestaan väitöskirjani valmistumiselle.

Vaikka olen työskennellyt ansiotyöni ohessa, niin taloudellinen toimeentulo ei ole jatkuvasti ollut itsestään selvää. Onneksi olen saanut tutkimustyötäni varten useita apurahoja. Lisensiaatintyötä tehdessäni sain tukea Emil Aaltosen säätiöltä ja Jyväskylän yliopiston humanistiselta tiedekunnalta. Väitöskirjan tekemisen alkuvaiheessa sain Ellen ja Artturi Nyyssösen säätiön apurahan ja loppuvaiheessa Jyväskylän yliopiston viimeistelyapurahan. Kiitän kaikkia apurahoja antaneita tahoja siitä, että väitöskirjani tekeminen on ollut taloudellisesti mahdollista aina silloin kuin olen saanut kerättyä siihen riittävästi aikaa ja motivaatioita. Myös pitkäaikainen työnantajani Jyväskylän ammattikorkeakoulu on mahdollistanut hyvin väitöskirjan teon antamalla opintovapaata aina tarvittaessa.

Kaikkein suurimman kiitoksen ansaitsee kuitenkin rakas perheeni eli puolisoni Pirjo sekä poikani Eero ja Janne. Pirjo - johon tutustuin aikoinaan Jyväskylän yliopiston historian laitoksella on tukenut minua aina ja kestänyt hyvin sen, että välillä yhteinen aikamme on ollut vähissä. Myös Eero ja Janne ovat ymmärtäneet hyvin ajoittaisen vetäytymiseni tutkimaan pölyisiä arkistoja ja kasvavia kirjakasoja. Väitöskirjan tekeminen ansiotyön ohessa on ollut välillä haasteellista, mutta työ on kuitenkin edennyt hitaasti mutta varmasti. Kaiken lisäksi väitöskirjan viimeistelyvaiheessa 
sairastuin melanoomaan, joka toivottavasti on siirtymässä sinne kuuluisaan historian hämärään. Kaiken kaikkiaan on loistavaa saada tämä pitkä, vaativa ja antoisa tutkimustyö lopulta päätökseen, jotta voin siirtyä muiden haasteiden pariin.

Uuden vuoden aattona 2014, Petri Jussila 


\section{Johdanto}

Suomen maatalouskysymys 1900-luvun alussa

Tarkastelen tässä tutkimuksessa Edvard Gyllingin (1881-1938) maatalouspoliittista ajattelua ja toimintaa suurlakon ja sisällissodan välisenä aikana. Gylling oli tuolloin sosialidemokraattisen puolueen maatalouspolitiikan asiantuntija, jolla oli tässä asiassa suuri merkitys puolueen linjauksiin ja sitä kautta laajemminkin suomalaiseen yhteiskuntaan. Koska hän oli sekä tutkija että poliitikko, molempien näkökulmien ymmärtäminen ja yhdistäminen mahdollistaa kokonaiskuvan luomisen hänen maatalouspoliittisista linjauksistaan ja ratkaisuistaan.

Maataloudessa tapahtui 1870-luvulta alkaen suuri muutos, kun aiemmin elämäntapaan perustunut tuotannon muoto alkoi kaupallistua yhä enemmän. Lähinnä maitotalouden tuotannon lisääntymisen vaikutuksesta koko maatalouden bruttotuotannon arvo kasvoi erittäin voimakkaasti 1890-luvulta alkaen. Kun maatalouden tuotannon laskennallisen arvon rakenne oli aiemmin koostunut suunnilleen puoliksi kasvinviljelystä ja monipuolisen karjatalouden tuotteista, nautakarjatalous sai 1800-luvun lopulta alkaen selvästi hallitsevan aseman. Taustalla oli muun muassa viljan maailmanmarkkinahinnan lasku 1800-luvun puolivälin jälkeen. ${ }^{1}$

Suomen 1900-luvun alun suurimpia yhteiskunnallisia ongelmia oli niin sanottu maatalouskysymys eli maanvuokraajien ja maatyöväen asema. Tuolloin puhuttiin yleensä vain torppareista

1 Vihola, Teppo, Leipäviljasta lypsykarjaan. Maatalouden tuotantosuunnan muutos Suomessa 1870-luvulta ensimmäisen maailmansodan vuosiin. Historiallisia tutkimuksia 159. Helsinki 1991, s.363-368. 
ja torpparikysymyksestä, kun tarkoitettiin kaikkia maanvuokraajia ja heidän asemaansa. Torpparit eli maatilan osa-alueen vuokranneet viljelijät olivat laajin maanvuokraajaryhmä. Maaseudun maanvuokraajiin kuuluivat heidän lisäkseen lampuodit eli päätilan alaisen koko tilan vuokranneet viljelijät sekä mäkitupalaiset eli pienen alueen vuokraajat, jotka viljelivät sitä sivuelinkeinonaan. ${ }^{2}$

Maatalouskysymys käsitti maanvuokraajien ja tilattoman väestön ongelmat. Se siis kosketti varsin suurta ihmismäärää. Esimerkiksi vuonna 1910 vuokraviljelmiä oli Suomessa 96 167, joista noin $19 \%$ oli kooltaan $0,5-1,0$ hehtaaria, noin $42 \%$ 1,0-3,0 hehtaaria ja noin $39 \%$ yli kolme hehtaaria. Samana vuonna itsenäisiä viljelmiä oli 125 172. Niistäkin suurin osa oli alle kymmenen hehtaarin tiloja. Torppareita oli alle 60000 perhettä, joihin kuului noin 150000 henkeä. Torpparin määrittely on kuitenkin vaikeaa ja tuotti aikalaisillekin hankaluuksia. Myöskään muun tilattoman väestön määrittely ei ollut yksiselitteistä, joten sen tarkkaa määrää on vaikea sanoa. Maaseudun työväki oli kuitenkin selvästi suurin maatalousväestön ryhmä. ${ }^{3}$

Varsinaiseen maaseudun tilattomaan väestöön kuului sekä vuosipalveluksessa olevia palkollisia että päivätyöläisiä. Rengit ja piiat - jotka olivat usein varsin nuoria - olivat vuosipalveluksessa. Erityisesti maan itä- ja keskiosissa myös naimisiin menneet miehet ja naiset saattoivat toimia palvelijoina. Naimisissa olevista, perheellisistä rengeistä käytettiin nimeä muonamies. Kun tavalliset rengit ja piiat olivat talon ruokatalouden piirissä, muonamiehen perhe asui omana ruokakuntanaan, erillisessä mökissä tai asuntolassa. Mäkitupalaiset, itselliset ja loiset olivat tavallisesti tilapäisessä työsuhteessa, usein päivätyöläisinä. Itsellinen puolestaan asui vuokralla toisen omistamassa asunnossa ja maksoi asumisestaan joko rahalla tai työnteolla. Loisiksi kutsuttiin työläisiä, joilla ei ollut

2 Rasila, Viljo, Suomen torpparikysymys vuoteen 1909. Historiallisia Tutkimuksia LIX. Helsinki 1961, s.16; Peltonen, Matti, Talolliset ja torpparit. Vuosisadan vaihteen maatalouskysymys Suomessa. Historiallisia Tutkimuksia 164. Helsinki 1992, s.21.

3 Peltonen 1992, s.267-269, 368-369. 
edes vuokra-asuntoa, joten he asuivat talollisen eli työnantajansa kanssa samassa talossa, joskus jopa samassa huoneessa. ${ }^{4}$

Suomen torpparijärjestelmä oli kriisiytymässä 1900-luvun alussa. Tämä johtui ennen kaikkea siitä, että maanvuokrat olivat kohonneet 1860-luvulta asti merkittävästi, mikä merkitsi torppareille kasvavaa taloudellista rasitusta. Maanvuokran osuus oli 1/3-1/14 kokonaissadosta, joskin alueelliset ja vuokratilakohtaisetkin erot olivat suuria. Kokonaisuutena katsoen vuokrarasitus oli selvästi suurempaa Etelä- ja Itä-Suomessa kuin Pohjois-Suomessa. Talollisväestönkin taloudellinen asema vaikeutui 1900-luvun alussa, mikä aiheutti muun muassa vuokratasojen nousua, lisääntyneitä ylipäiviä ja torpparihäätöjen yleistymistä. Lisäksi samaan omaisuuteen oli kaksi erilaista omistusvaatimusta. Talolliset omistivat alustalaistensa maat oikeuden vahvistamien kauppakirjojen tuella, torpparit vanhaan - ei enää voimassa olevaan - ruotsalaiseen lakiin perustuvan oikeuskäytännön mukaisesti. Tässä tilanteessa valtion oli valittava, mitä oikeutta se halusi ylläpitää. ${ }^{5}$ Voidaan siis sanoa, että torpparin asema oli oikeudellisesti epäselvä ja taloudellisesti epävarma.

Torpparikysymystä ajateltiin usein pääosin oikeudellisena epäkohtana, mutta torpparille itselleen se oli ennen kaikkea toimeentuloon liittyvä taloudellinen kysymys. 1800- ja 1900 -lukujen vaihteessa torppareiden taloudellinen asema heikkeni suhteessa talollisiin ja torpanpito tuli entistä epävarmemmaksi. Samalla heidän taloudellinen etumatkansa suhteessa varsinaisiin maatyöläisiin pieneni, joka heikensi heidän suhteellista asemaansa. Tämä aiheutti torpparien piirissä katkeroitumista ja poliittista radikalisoitumista, johon liittyi erilaisia lakkoliikkeitä. ${ }^{6}$

4 Östman, Ann-Catrin, Modernisoituva maatalous. 1870-luvulta ensimmäiseen maailmansotaan. Teoksessa Suomen maatalouden historia 2. Kasvun ja kriisien aika 1870-luvulta 1950-luvulle. Toim. Peltonen, Matti. Helsinki 2004, s.56.

5 Peltonen 1992, s.244-249, 280-285, 299.

6 Haapala, Pertti, Kun yhteiskunta hajosi. Suomi 1914-1920. Helsinki 1995, s.112; Soininen, Arvo M., Torpparilaitos yhteiskunnallisena instituutiona. Haik 1/1999, s.33-34. 
Kaiken kaikkiaan voidaan siis sanoa, että torpparien ja muiden maanvuokraajien asema oli 1900-luvun alussa vaikea. Alustalaisviljelmien tuotto oli alhainen ja mahdollisuudet rahatulojen hankkimiseen rajalliset. Vuokraviljelmän tuotosta vain maitotaloustarvikkeita liikeni myyntiin ja silloinkin keskityttiin yleensä kotivoin valmistukseen. Sivuansioiden hankkiminen oli vaikeaa, koska päivätyövelvollisuus rasitti vuokralaisperheen työikäisiä erityisesti kesäaikaan, jolloin piti hoitaa myös torpan viljelystyöt. Vaikka tulotaso oli alhainen, maanvuokra vei vielä huomattavan osuuden vuokraviljelmän tuotosta. Torpparikysymyksen alueelliset erot olivat kuitenkin suuret. Vuokrarasitus oli ankarinta Etelä- ja Itä-Suomessa, mutta tuntui vain lievänä Pohjois-Suomessa. ${ }^{7}$

Torpparilaitos oli kaikesta päätellen aluksi edistyksellinen ratkaistessaan yhteiskunnallisia ongelmia ja vakiintui vähitellen osaksi suomalaista yhteiskuntaa. Torpparilaitos ei kuitenkaan kyennyt mukautumaan 1800-luvun puolivälin jälkeen alkaneeseen maataloudelliseen ja yhteiskunnalliseen kehitykseen. 1900-luvun alussa se oli jo vanhentunut instituutio, josta oli tullut taloudellista kehitystä hidastava tekijä. Ilmeisesti torppareiden asema oli alun alkaen kohtuullisen hyvä, mutta 1800-luvun lopulla heidän asemansa heikkeni taloudellisesti ja tuli epävarmemmaksi. Taustalla oli ennen kaikkea muutokset metsätaloudessa ja kasvinviljelyssä. ${ }^{8}$

Suomen maatalousväestö jakautui vuoden 1910 paikkeilla karkeasti seuraavasti: viljelijäväestöä oli noin $40 \%$, torppariväestöä noin $20 \%$ ja maataloustyöläisiä noin 40 \% koko väestöstä. Miespuolisen väestön perusteella mitaten viljelijäväestöä oli selvästi yli tämän ja maataloustyöväkeä selvästi alle tämän, mutta naispuolisen väestön mukaan ottaminen laskelmiin tasoittaa tilanteen edellä kuvatun kaltaiseksi. Olot maan eri osissa poikkesivat kuitenkin huomattavasti koko maan keskimääräisestä tilanteesta. ${ }^{9}$

7 Peltonen, Matti, Torpparikysymys. Teoksessa Suomen maatalouden historia 2. Kasvun ja kriisien aika 1870-luvulta 1950-luvulle. Toim. Peltonen, Matti. Helsinki 2004, s.251-252.

8 ks. esim. Soininen 1999, s.25-36.

9 Soininen, Arvo M., Maatalousväestö v.1919 - tilasto ja todellisuus. HAik 3/1976, s.221-225. Soininen käytti määritellessään "torppari” käsitettä Ti- 


\section{Sosialidemokraattien vaikea suhde maatalouden}

kehitykseen

Kansainvälisen työväenliikkeen aatteellisen pohjana 1900-luvun alussa olivat Karl Marxin (1818-1883) ja Friedrich Engelsin (1820-1895) muotoilemat sosialistiset teoriat, joiden ajankohtaisuudesta käytiin tuolloin vilkasta keskustelua. Maatalouden kehitys oli osoittautunut erityisen ongelmalliseksi teorian ja käytännön yhdistämisen kannalta. Karl Kautsky (1854-1938) puolusti näkemystä, jonka mukaan siirtyminen suurtuotantoon tapahtuisi vähitellen maataloudessakin. 1900-luvun alussa voimistui kuitenkin mielipide, joka katsoi maatalouden kehityksestä tehtyjen havaintojen osoittavan pienviljelyn laajenevan. Näkemystä edusti työväenliikkeen oikeiston johtaja, revisionismin isä Eduard Bernstein (1850-1932). ${ }^{10}$

Karl Kautskyn kirjoittaman Erfurtin ohjelman mukaan suurtuotanto syrjäyttää kapitalismin kehittyessä pientuotannon. Hän kuitenkin myönsi, että maataloudessa tämä kehitys oli ollut odotettua hitaampaa ja paikoitellen pientuotanto oli jopa voittanut alaa, vaikka toisaalta pienviljelijöitä uhkasi proletarisoituminen. Kautskyn mielestä oli kuitenkin ennenaikaista päätellä, että Marx olisi pitkällä tähtäimellä ollut väärässä. Bernstein puolestaan katsoi, että todellisuus oli osoittanut keskittymisteorian ainakin maataloudessa vääräksi. Hänen mukaansa teollisuus ja kauppakin osoittavat hitaampaa kehitystä kohti suurtuotantoa kuin oli oletettu mutta maanviljelyksessä kehityksen suunta näyttäisi olevan ennemmin päinvastainen. Hän perusteli tätä tilastollisella

lastollisen päätoimiston väestötilaston määritelmää, jonka hän toteaa varsin epätarkaksi. Samalla hän osoittaa päätoimiston tekemät laskelmat virheelliseksi, koska niissä todetaan maanomistajien lukumäärä paljon todellista pienemmäksi.

10 Rautio, Veli-Matti, Die Bernstein-Debatte. Die politisch-ideologischen Strömungen und die Parteiideologie in der Sozialdemokratischen Partei Deutschlands 1898-1903. Studia Historica 47. Helsinki 1994, s.117-142. 
aineistolla, jossa käsiteltiin Saksan ja Britannian tilojen kehitystä 1800-luvun lopulla. ${ }^{11}$

Suomen työväenliikkeelle maatalouden suuntaa koskeva ongelma oli erityisen tärkeä, koska Suomi oli 1900-luvun alussa vielä vahvasti maatalousvaltainen maa. Vuonna 1899 Turussa perustettiin Suomen Työväenpuolue, jolle laadittiin samalla ensimmäinen tavoiteohjelma, jossa oli vahvasti esillä myös torppariasia. Ohjelmassa vaadittiin maanvuokraehtojen parantamista monella eri tavalla, kuten 50 vuoden säätämistä lyhimmäksi vuokra-ajaksi, kirjallisia sopimuksia, korvauksia tehdyistä parannuksista ja kymmentuntista työpäivää. Työväenpuolueesta tuli näin maanvuokrajien aseman tuntuvaa parantamista vaativa ja torppareihin vetoava liike. Kahden vuoden päästä Viipurin puoluekokouksessa asiasta keskusteltiin periaatteellisemmalta kannalta, jolloin esille nousi kolme linjaa: maanvuokraehtojen parantamisen, torpparien itsenäistäminen pienviljelijöiksi ja sosialismin teoriaan vetoava kanta, joka tosin ei antanut selvää vastausta kysymykseen. Maatalouskysymyksestä ei kuitenkaan saatu aikaan periaatteellista yksimielisyyttä, joten puoluekokous tyytyi vain joihinkin käytännöllisiin ehdotuksiin. ${ }^{12}$

Vuoden 1903 Forssan puoluekokoukseen puoluehallinto laati pääasiassa Norjan työväenpuolueen ohjelman pohjalta viisi kohtaa käsittävän ehdotuksen, jonka keskeisenä tavoitteena oli sosialististen periaatteiden tuominen maatalousohjelmaan. Ehdotuksen keskeisinä ajatuksina oli yhteiskunnan omistuksen lisääminen ja maatalousosuuskuntien muodostamisen vauhdittaminen. Ehdotus sai osakseen ankaraakin kritiikkiä, ensinnä koska se lupasi torppareille paljon vähemmän kuin Turussa 1899 hyväksytyt ponnet ja toiseksi siksi, ettei maanviljelysosuuskunta-ajatusta pidetty

11 Kautsky, Karl, Erfurtin ohjelma. 3. suomenkielinen painos. Helsinki 1974(1891), s.13-14. Ks. Kautskyn maatalauspolitiittisista näkemyksistä myös ; Kautsky, Karl, The Agrarian Question. In two volumes. Translated by Pete Burgess. London 1988 (1899), s.168-197; Bernstein, Sosialismin edellytykset ja sosialismin tehtävät. Näköispainos Juva 1982 (1910), s. 90-96; Rautio 1994, s. 117-142.

12 Soikkanen, Hannu, Kohti kansanvaltaa 1, SDP:n historia, vuodet 1899 1937. Vaasa 1975, s.43-44,49-50. 
elinkelpoisena. Maatalousohjelmasta käytiin kipakkaa keskustelua ja kolme työväenyhdistystä laati uuden ehdotuksen alkuperäisen ehdotuksen rinnalle. Lopulta maatalousohjelma muodostui pitkälti Tampereen yhdistyksen ehdotuksen mukaisesti. ${ }^{13}$

SDP:n vuoden 1903 Forssan ohjelmaan tuli siis erillinen maatalousosa, jossa pyrittiin erilaisin keinoin saamaan valtion ja kuntien omistukseen lisää maata ja tiloja. Valtion omistavat maat piti antaa viljeltäväksi tilattomille tai osuuskunnille, mutta ei omistusoikeudella. Lisäksi valtion oli tuettava taloudellisesti pienviljelystä ja osuustoimintaa. Maanvuokraajille vaadittiin täydellistä käyttöja myyntioikeutta viljelystuotteisiinsa ja tehdystä työstä maksettavaa korvausta. Erillisohjelmassa vaadittiin myös metsästys- ja kalastusoikeuden tekemistä riippumattomaksi maanomistuksesta, maaseudun väestön sivistämistä ja palkollissäännön kumoamista. Forssan ohjelman periaatteellisen osa oli kuitenkin ristiriidassa maatalousohjelman kanssa. Edellisessä todettiin kehityksen kulkevan kohti suurtuotantoa kun taas jälkimmäisessä tuettiin pienviljelystä. ${ }^{14}$ Ristiriitaisuuden taustalla oli sosialidemokraattien piirissä yleisesti vallinnut epävarmuus maatalouden suunnasta.

\section{Kuka oli Edvard Gylling?}

Edvard Otto Wilhelm Gylling syntyi Kuopiossa 30.11.1881. Hänen vanhempansa olivat piiri-insinööri Uno Alexander Gylling ja Eugenie Viktoria Klotilda Henriette Helsingius. Perheeseen syntyi kymmenen lasta, joista kaksi kuoli kuitenkin jo nuorena. Edvard oli perheen toinen lapsi. Hänen isänsä Uno Gylling oli insinööri ja äitinsä Eugenie kuului tunnettuun Helsingiuksen kulttuurisukuun. Edvard Gylling siis syntyi sivistyneeseen porvariskotiin. ${ }^{15}$

13 Soikkanen 1975, s.55-56.

14 Suomen Työväenpuolueen toisen puoluekokouksen ohjelma on painettuna Borg Olavi, Suomen puolueet ja puolueohjelmat 1880-1964. Porvoo 1965 (A), s.31-36.

15 Esim. Ylärakkola, Arvo, Edvard Gylling, Keuruu 1976, s.14-15. 
Edvard Gylling kirjoitti ylioppilaaksi Jyväskylän lyseosta keväällä 1900, jonka jälkeen hän aloitti yliopisto-opinnot Helsingissä. Gylling valmistui vuonna 1903 filosofian kandidaatiksi pääaineenaan maanviljelyksen kansantalous- ja tilastotiede. Vuonna 1904 hän harjoitti jatko-opintoja Berliinissä. ${ }^{16}$

Gylling avioitui vuonna 1906 Fanny Achrénin kanssa. Heille syntyi kolme lasta, Maija, Lena ja Walter. ${ }^{17}$ Vuosisadan alun kuohuvassa ilmapiirissä hän liittyi sosialidemokraatteihin, kuten monet muutkin akateemiset nuoret 1900-luvun alussa. Gyllingin lisäksi heistä merkittävimpiä olivat Väinö Tanner (1881-1966), Otto Ville Kuusinen (1881-1964), Yrjö Sirola (1876-1936), Kullervo Manner (1880-1936), K. H. Wiik (1883-1946), Sulo Wuolijoki (1881-1957) ja Väinö Wuolijoki (1872-1947).

Gylling toimi myös merkittävänä tutkijana. Hän johti vanhuus- ja invalidivakuutusta käsittelevää tutkimusta, joka ilmestyi kahtena laajana niteenä vuosina 1906 ja 1907. Gylling väitteli torpparilaitoksen historiasta vuonna 1909, jonka jälkeen hänet nimitettiin Helsingin yliopiston tilastotieteen dosentiksi. Hänellä oli eri tehtäviä tilastollisessa päätoimistossa ja tullihallituksen tilastokonttorissa, kunnes hän vuonna 1912 sai vakinaisen aktuaarin viran Helsingin kaupungin tilastokonttorista. Väitöskirjansa jälkeen Gylling tutki lähinnä maatalous- ja väestökysymyksiä. ${ }^{18}$

Gylling toimi sosialidemokraattien kansanedustajana vuodesta 1908 sisällissotaan ${ }^{19}$ asti, lukuun ottamatta vuoden 1910 valtiopäi-

16 Heikkinen, Sakari - Mauranen, Tapani, Edvard Gylling. Tiede ja edistys 4/ 1981, s.52.

17 Salomaa, Erkki, Edvard Gylling. Teoksessa Tiennäyttäjät 2. Toim. Hannu Soikkanen. Rauma 1967, s.167; Ylärakkola 1976, s.20.

18 Kovero, Martti, Gylling, Edvard Otto Vilhelm. Teoksessa Kansallinen elämäkerrasto II. Porvoo 1929, s.302-303; Heikkinen - Mauranen 1981, s. 53-55.

19 Vuoden 1918 sodasta on käytetty monenlaisia nimityksiä, kuten vapaussota, punakapina, vallankumous ja luokkasota. Kaikki nämä kuvaavat kyseistä sotaa tietystä näkökulmasta, mutta jättävät tapahtumien moni-ilmeisestä luonteesta jotakin pois. Kokonaisvaltaisempi nimitys on nykyään yleisimmin käytetty kansalaissota. Se kuitenkin tekee tapahtumasta liian ainutkertaisen ja erottelee sen muualla käydyistä samankaltaisista sodista. 
viä. Hän oli myös SDP:n puoluetoimikunnan jäsen vuodesta 1913 alkaen. Gyllingin akateemisella koulutuksella ja laajalla lukeneisuudella oli puolueessa runsaasti käyttöä, sillä hän muun muassa kirjoitti ahkerasti työväenliikkeen lehtiin ja luennoi puolueopistossa. ${ }^{20}$

Gylling oli mukana neuvottelemassa Suomen itsenäisyydestä sekä Venäjän väliaikaisen hallituksen että V. I. Leninin (18701924) johtaman bolševikkihallituksen kanssa. Hän vastusti aseellista vallankumousta, eikä ensin mennyt mukaan punaisten toimintaan. Vedoten solidaarisuuteen työväenliikettä kohtaan hän muutti kuitenkin mielensä ja siirtyi kansanvaltuuskunnan rahaasiain valtuutetuksi. Sisällissodan aikana Gylling toimi Viipurissa punakaartin viimeisenä esikuntapäällikkönä. ${ }^{21}$

Sisällissodan jälkeen Gylling siirtyi maan alle piilotellen vallankumousyrityksestä sivussa pysyneiden sosialidemokraattien, kuten Miina Sillanpään (1866-1952) ja Väinö Tannerin luona. ${ }^{22}$ Hän pakeni lopulta Tukholmaan ja oli siellä vajaan kaksi vuotta. Gylling suunnitteli Ruotsista käsin aktiivisesti Karjalan Työkansan

Sisällissota-nimitystä voidaan arvostella siitä, että sodassa oli mukana myös venäläisiä, saksalaisia ja ruotsalaisia joukkoja. Toisaalta ulkomaisia joukkoja oli runsaasti myös esimerkiksi Espanjan vuosien 1936-1939 sodassa, jota silti yleisesti kutsutaan Espanjan sisällissodaksi. Kun taistelut Suomessakin käytiin pääosin kotimaisin joukoin, osuvin nimitys vuoden 1918 sodalle on Suomen sisällissota, jota siis käytän tässä tutkimuksessa. Historiallisen Aikakauskirjan (HAik) numerossa 2/1993 vuoden 1918 sodan eri nimityksiä avataan valaisevasti, ks. Väisänen, Seppo, Kansalaissota, s.98-102; Ernrooth, Jari, Kapina, s.98-105, Haapala, Pertti, Luokkasota, s.105-110; Ylikangas, Heikki, Sisällissota, s.110-114; Alapuro, Risto, Vallankumous, s.114-116 ja Manninen, Ohto, Vapaussota, s.116-120.

20 Salomaa 1967, s.173-175; Ylärakkola 1976, s.35-37.

21 Soikkanen, 1975, s.212-214, 248-250, 263-265, 268, 288-289; Heikkinen - Mauranen 1981, s.55-56. Nykyisessä termistössä raha-asiain valtuutettu vastaa lähinnä valtiovarainministeriä; Keskisarja, Teemu, Viipuri 1918. Helsinki 2013, s.273-280.

22 Ylärakkola 1976, s.87-88; Paavolainen, Jaakko, Väinö Tanner, senaattori ja rauhantekijä. Elämäkerta, osa 2. Helsinki 1979, s.216-217. 
Kommuunin perustamista ja oli asiasta yhteydessä Neuvosto-Venäjän johtoon. Vuonna 1920 hän siirtyikin Neuvosto-Venäjälle. ${ }^{23}$

Gyllingistä tuli Karjalan autonomisen sosialistisen neuvostotasavallan pääministeri, Karjalan työkommuunin vallankumouskomitean puheenjohtaja ja Karjalan talousneuvoston puheenjohtaja. Hän vaikutti suomalaisen kulttuurin ja kielen pysymiseen elinvoimaisena alueella, vaikka tämä linja kohtasi aika ajoin myös vastustusta. Hallinnolliset toimet veivät pääosan Gyllingin ajasta, joskin hän toimi myös Karjalan tieteellisen tutkimuslaitoksen johtajana vuosina 1931-1935. ${ }^{24}$

Neuvostoliiton diktaattorin J. V. Stalinin (1879-1953) käynnistämät puhdistukset alkoivat 1930-luvulla. Vuonna 1933 kiristettiin otetta sekä venäläistä kansallista kiihkoilua että paikallista nationalismia vastaan. Gylling erotettiin kesällä 1935 tehtävistään syytettynä nationalistisesta toiminnasta. Hän työskenteli tämän jälkeen Moskovassa Maailmantalouden ja maailmanpolitiikan instituutin tutkijana. ${ }^{25}$

Stalinin julma politiikka koitui lopulta Gyllingin kohtaloksi, sillä hänet vangittiin kesällä 1937 ja erotettiin kansanvihollisena Neuvostoliiton Kommunistisesta Puolueesta. Gylling sai syytteet suomalaisesta nationalismista ja vastavallankumouksellisuudesta, joiden takia hänet teloitettiin 14.6.1938. Muodollisesti hänen rikoksekseen katsottiin tuotanto- ja elintarvikevarojen väärinkäyttö eräässä metsäkollektiivissa. ${ }^{26}$

23 Ylärakkola 1976, s.93-97, 110-11; Kangaspuro, Markku, Neuvosto-Karjalan taistelu itsehallinnosta. Nationalismi ja suomalaiset punaiset Neuvostoliiton vallankäytössä 1920-1939. Helsinki 2001, s.74-75, 91-92.

24 Heikkinen ja Mauranen 1981, s.56; Rautkallio, Hannu, Suuri viha. Stalinin suomalaiset uhrit 1930-luvulla. Juva 1995, s.31-41, 93-95; Markku Kangaspuro käsittele näitä vaiheita yksityiskohtaisesti tutkimuksessaan. Ks. tarkemmin Kangaspuro 2001, s.89-147.

25 Rautkallio 1995, s.157,198-201; Kangaspuro 2001, s.319-323.

26 Tiedot Gyllingin viimeisistä vaiheista ovat olleet ristiriitaisia, koska Neuvostoliitosta on ollut vaikea saada luotettavaa tietoa. Tilanne on parantunut viime vuosina, ja tutkijat ovat saaneet käyttöönsä uutta aineistoa. Afenasjevan, Takalan ja Rautkallion tutkimukset pohjautuvat uuteen materiaaliin, joten niiden antama kuva lienee ainakin pääpiirteissään oikea. Afanasje- 
Monien muiden tavoin Edvard Gyllingin kunnia palautettiin 1950-luvulla Stalinin kuoltua. Pidätys todettiin lainvastaiseksi, eikä häntä vastaan esitetyistä syytteistä löydetty todisteita. ${ }^{27}$

Gyllingin elämänkaari sisälsi varsin dramaattisia ja traagisiakin käänteitä. Häntä onkin joskus myös heronisoitu korostamalla hänen uhrautuvaisuuttaan ja velvollisuudentuntoaan punakaartin esikuntapäällikkönä. Gyllingin elämästä on muun muassa tehty dokumenttikuunnelma, missä hänet esitetään idealistisena älykkönä. ${ }^{28}$ Pentti Saarikoski on vanginnut runossaan Viimeiseen asti Gyllingin elämän traagiset ja tapahtumarikkaat piirteet. ${ }^{29}$ Sisällissodan loppuvaiheesta Saarikoski kirjoittaa seuraavasti:

va, Aleksandra, Materiaalia Edvard Gyllingin viimeisistä elinkuukausista. Teoksessa Edvard Gylling 1881-1991. Ikaalinen 1991, s.40; Takala, Irina, Gyllingin - Rovion juttu. Carelia 9/1991, s.132-138; Rautkallio 1995, s.200201. Edvard Gyllingin kuolinajankohdasta on esitetty monia - ilmeisesti siis virheellisiä - väitteitä. Salomaa 1961, s.161 tukeutuu viralliseen kuolintodistukseen, jonka mukaan Gylling kuoli 19.8.1944. Ylärakkola 1976, s.324 katsoo, että Gylling kuoli Sahalinin saarella 13.2.1944. Hodgsonin mukaan hän kuoli vuonna 1942. Ks. Hodgson, John H., Edvard Gylling ja Otto Ville Kuusinen asiakirjojen valossa 1918-1929. Helsinki 1974, s.16. Fanny Gylling vangittiin vuonna 1938 ja tuomittiin kahdeksaksi vuodeksi vankeuteen yhteydestä "kansanviholliseen" mieheensä. Hänen kuolinajankohdastaan ei ole varmaa tietoa.

27 Afanasjeva 1991, s.40.

28 Kalemaa, Kalevi, Edward Gylling, Karjalan kuningas. Dokumenttikuunnelma vuodelta 1987. Tämäntyyppinen osittain fiktiivinen kuunnelma voi parhaimmillaankin toimia tutkimuksessa vain ajatusten herättäjänä. Tämä sinänsä kiinnostava kuunnelma keskittyy kuitenkin Gyllingin elämään Neuvostoliitossa, joten tässäkin mielessä sen arvo tutkimusaiheen kannalta on vähäinen.

29 Saarikoski, Pentti, Tanssiinkutsu. Keuruu 1980, s.59-61. 
Viipurin linnansalissa yksin

kun neuvottelut valkoisten kanssa olivat päättyneet

tuloksetta

hän pysähtyi hetkeksi ikkunaan

katsoi joukkojensa rippeitä

lumi katoilta rojahtaa kohta

hän ajatteli koivukujaa kotikartanossa Ikaalisissa

armeija sortui

\section{Aikaisempi tutkimus}

Gylling oli siis erityisesti 1900-luvun alun maatalouspolitiikan ja -kysymysten asiantuntija. Tuon ajan maatalouskysymyksestä on tehty melko paljon tutkimusta. Viljo Rasilan tutkimukset Suomen torpparikysymys vuoteen 1909 ja Torpparikysymyksen ratkaisuvaihe. Suomen torpparikysymys vuosina 1909-1918 ovat edelleen alan perusteoksia, joissa maatalouskysymyksen historiallinen kehitys tuodaan esiin monipuolisesti, mutta silti melko yksityiskohtaisesti. Nämä Rasilan teokset ovat tutkimusaiheeni kannalta erittäin merkittäviä, sillä ne auttavat rakentamaan kontekstia Gyllingin ajattelulle ja toiminnalle. Gylling esiintyy noissa tutkimuksissa maatalouskysymysten asiantuntijana ja sosialidemokraattisena poliitikkona. Rasila tuo Gyllingin esiin yhtenä torpparikysymyksen keskeisistä toimijoista ja asiantuntijoista, jonka rooli tutkijana ja kansanedustajana oli tässä suhteessa tärkeä.

Myöhemmistä tutkimuksista erittäin merkittävä on Matti Peltosen väitöskirja Talolliset ja torpparit. Vuosisadan vaihteen maatalouskysymys Suomessa, jossa hän lähestyy maatalouden kehitystä ennen kaikkea maailmankaupan kehityksen kautta, joka heijastui myös Suomen maaseudun oloihin. Samalla tutkimus tuo uuden näkökulman maatalouden nykyaikaistumiseen ja sen väestöryhmien välisiin suhteisiin. Peltonen tarkentaa historiallisen 
katseensa torpparikysymykseen teoksessa Suomen maatalouden historian osassa toisessa, jossa muutenkin kuvataan monipuolisesti aikakauden maatalousoloja. ${ }^{30}$ Peltosen esittämien taloudellisten analyysien lisäksi myös Arvo M. Soininen on tehnyt uraauurtavaa kvantitatiivista tutkimusta Suomen maatalouden kehityksestä, ja julkaissut asiaa erinomaisesti valaisevia artikkelia. ${ }^{31}$

Todettakoon vielä, että torpparit ovat olleet esillä myös kaunokirjallisuudessa, mikä on vaikuttanut ainakin jonkin verran myös maanvuokraajien asemasta käytyyn keskusteluun ja poliittiseen käsittelyyn. Varsinkin 1800-luvun loppupuolella ja 1900-luvun alussa torpparien asemaa käsiteltiin monista näkökulmista useissa kaunokirjallisissa teksteissä. Ajanjakson alkupuolella torppari kuvattiin ennen kaikkea tarpeelliseksi, turvatuksi ja menestyväksi mutta vuosisadan vaihteesta varsinkin työväenkirjallisuudessa korostui torpparien epävarma asema ja häätöuhka. Todella vahvasti suomalaisten tietoisuuteen torpparit tunkeutuivat tietysti vasta Väinö Linnan klassikkotrilogian Täällä Pohjantähden alla myötä. ${ }^{32}$

Viimeistään Väinö Linnan teoksen myötä torpparien asema vuoden 1918 sisällissodassa nousi keskustelun keskiöön. Teoksessa kuvataan maaseudun elämää ja ihmisiä varsin monipuolisesti, mutta sen pääosassa on Koskelan torppariperhe, joista tulee paikallisen työväenliikkeen johtajia ja lopulta myös punakaartilaisia. Torpparin muotokuvaksi muodostui Akseli Koskela, ahkera työntekijä, joka oli myös poliittisesti aktiivinen vasemmistolainen ja lopulta valmis ajamaan asiaansa myös ase kädessä. Täällä Pohjantähden alla -trilogia saavutti suuren menestyksen ja myöhemmin suorastaan Suomen kansallisromaanin aseman, vaikka monet historiantutkijat arvostelivat sen historiallista totuudenmukaisuutta

\section{Peltonen 2004.}

31 Ks. erityisesti Soininen 1976 ja Soininen 1999.

32 Ks. tarkemmin Huhtala, Liisi, Kuu torpparin aurinko. Torppari-aihe suomalaisessa kaunokirjallisuudessa 1809-1918. Suomalaisen kirjallisuuden seuran toimituksia 371. Savonlinna 1981, erit. s.168-172. 
ja kuvauksen yksityiskohtia. ${ }^{33}$ Joka tapauksessa Linnan romaanitrilogian vaikutus suomalaisten historiakuvaan oli suuri ja torpparien epäoikeudenmukainen asema alettiin käsittää sisällissodan keskeiseksi syyksi. Tutkittaessa torpparikysymystä ja laajemmin maatalouden ongelmia kannattaakin aina tiedostaa vaara lähestyä aihetta jälkiviisaudella ja myöhempien tapahtumien valossa, tässä tapauksessa tietysti vuoden 1918 näkökulmasta.

Gyllingin maatalouspoliittisen ajattelun ymmärtäminen edellyttää myös sosialidemokraattien aatteellisen kehityksen tarkastelua, erityisesti suhteessa maatalouskysymyksiin. Hannu Soikkasen uraauurtavista tutkimuksista erityisesti SDP: $\mathrm{n}^{34}$ historian ensimmäinen osa Kohti Kansanvaltaa I valaisee laajasti vanhan työväenliikkeen aatteellista kehitystä ja sitä kautta myös Gyllingin toiminnan ja ajattelun taustoja. Hän tulee siinä esiin erityisesti maanvuokrakysymysten asiantuntijana. Jari Ehrnroothin laajaa polemiikkia aiheuttaneessa väitöskirjassa Sanan vallassa, vihan voimalla. Sosialistiset vallankumousopit ja niiden vaikutus Suomen työväenliikkeessä 1905-1914 taustoitetaan hyvin Gyllingin toimintaa SDP:n puolueopistossa.

Viime vuosina on tehty paljon hyviä tutkimuksia erityisesti suurlakosta, joiden kautta kuva siitä on syventynyt ja monipuo-

33 Linnan saamasta vastaanotosta ja siihen liittyvästä keskustelusta tarkemmin Haapala, Pertti, Väinö Linnan historiasota. HAik 1/2001, s.25-34. Viljo Rasila on analysoinut vuoden 1910 luokkarakennetta varsin korkeatasoisesti HAik:ssa. Ilmeisesti torppareita taisteli suurin piirtein saman verran sekä punaisten että valkoisten puolella. Tosin Etelä-Suomessa torpparit taistelivat valtaosin punaisten puolella, mutta Pohjanmaalla ja Pohjois-Suomessa taas valkoisten puolella. Kaiken kaikkiaan torpparit kuuluivat maatalousväestön keskiluokkaan, jonka alapuolella olivat mäkitupalaiset, varsinainen työväestö ja täysin varattomat ihmiset. Torppareiden yläpuolella olivat taas tilalliset, talolliset ja yhteiskunnan varsinainen eliitti. Näin ollen torpparien jakautuminen vuoden 1918 sisällissodan molempien puolten taakse on varsin ymmärrettävää. Ks. Rasila,Viljo,Vuoden 1910 yhteiskunnan kerrostumat. HAik 4/1995, s.305-312.

34 Vanhasta sosialidemokraattisesta puolueesta on usein käytetty lyhennettä sos.-dem. puolue. Tässä tutkimuksessa käytetään kuitenkin käytännöllisempää lyhennettä SDP, vaikka se perinteisesti on viitannut lähinnä 1960-luvun jälkeiseen aikaan. 
listunut. Näistä mainittakoon monien kirjoittajien tekemät Kansa kaikkivaltias. Suurlakko Suomessa 1905 ja Kuriton kansa. Poliittinen mielikuvitus vuoden 1905 suurlakon ajan Suomessa sekä Marko Tikan Kun kansa leikki kuningasta. Suomen suuri lakko 1905. Suomen kansanedustuslaitoksen historia on laajuudessaan ja monipuolisuudessaan perusteellinen teos, josta on löytynyt paljon tärkeää taustatietoa tähänkin tutkimukseen. Sitä täydentää hyvin tuore Eduskunnan 100-vuotishistoria. Molemmat 12-osaiset kirjasarjat syventävät osaltaan käsitystä aikakauden lainsäädännön ja demokratian historiasta.

Suomen itsenäistyminen ja sisällissota ovat kiinnostaneet erittäin paljon historiantutkimusta. Sisällissota on ollut jatkuvan keskustelun ja väittelyn kohteena. Aiheesta on kirjoitettu lukuisasti eri näkökulmista. Joukossa on objektiivisuuteen pyrkivän korkeatasoisen tutkimuksen lisäksi myös voimakkaan puolueellisia tekstejä, joissa kehitys nähdään yksipuolisesti joko valkoisen tai punaisen puolen näkökulmasta. Puolueellisuus oli erityisen selkeää heti sisällissotaa seuranneina vuosikymmeninä, jolloin sekä voittanut että hävinnyt puoli tulkitsi asioita vahvasti omasta näkökulmastaan. Voittaneen valkoisen puolen näkökulma oli hallitseva, kunnes 1950-luvulla alkoi kamppailu sodan syistä, luonteesta ja myös nimestä. Seuraavina vuosikymmeninä aiheen käsittelyssä päästiin kohti tasapuolista ja neutraalia käsittelyä, jolloin kummankin osapuolen näkökulmia ja toimintaa alettiin käsitellä yhä monipuolisemmin. ${ }^{35}$

Gyllingin tutkimustyötä käsitellään useassa tieteenhistoriallisessa yleisesityksessä, mutta sitä ei voi yksiselitteisesti sijoittaa minkään tieteenalan piiriin, varsinkin kun käsitykset niiden luonteesta ovat jatkuvassa liikkeessä. Kari Pitkänen analysoi Gyllingin väestötutkimuksia teoksessaan Väestöntutkimus ja yhteiskunta. Suomalaisen väestötutkimuksen historia 1700-luvulta noin vuoteen 1950. Gyllingiä käsitellään myös suomalaisen sosiologian historian yleisesityksessä, josta on tehty kaksi eri painosta. Tosin

35 Mylly, Juhani, Vallan syli ja puristus - suomalaisen historiatutkimuksen suhde poliittiseen valtaan. HAik 1/1999, s.60-63; Peltonen, Ulla-Maija, Muistaa vai unohtaa? Vuoden 1918 vaikea historia. HAik 4/2003, s.492-496. 
uudemmassa laitoksessa marxilaista tutkimusta ei käsitellä lainkaan omana lukunaan, mikä kuvannee myös yleisempää muutosta 1970-luvun alun ja 1990-luvun alun tilanteen välillä. ${ }^{36}$ Suomalaisen yhteiskuntatieteen yleisesityksessään Erik Allardt kuvaa Gyllingin empiirisesti orientoituneena yhteiskuntatieteilijänä, joka kehitti sosialistisen teorian pohjalta ansiokkaasti luokkateoriaa. ${ }^{37}$ Gylling sivuutetaan nopeasti Päiviö Tommilan teoksessa Suomen historiankirjoitus. Tutkimuksen historia, mutta siitä löytyy paljon aineksia hänen ajattelunsa taustojen hahmottamiseen. Gyllingin tieteellisen ajattelun kehittymiseen ja yleisemminkin tieteen kehittymiseen saa näistä kaikista teoksista tärkeitä tietoja ja näkökulmia.

Tämän tutkimuksen kannalta sellaiset henkilöhistorialliset tutkimukset, joiden kohteena on sekä tiedemiehenä että poliitikkona toiminut ihminen, ovat kiinnostavia, koska ne rinnastuvat Gyllingin toimintaan. J. V. Snellmania (1806-1881) ja Yrjö Koskista $(1830-1903)^{38}$ koskenut laaja tutkimus on viime vuosina saanut rinnalleen tuoreempia tiedemies ja poliitikko -problematiikan sisältäviä teoksia, jotka monet lisäksi käsittelevät 1900-luvun alkua. Tällaisia ovat muun muassa Jukka Tervosen väitöskirja J. R. Danielson-Kalmari. Historiantutkija ja -opettaja ja Timo Soikkanen erinomainen teos Yrjö Ruutu. Näkijä ja tekijä. Erkki Tuomiojan varhaisempi tutkimus $K$. H. Wiik. Itsenäisyysmies ja nationalisti on aiheeni kannalta kiinnostava, koska Wiikin (1883-1946) elämänkaaressa ja ajattelussa on paljon samanlaisia aineksia kuin Gyllingillä. Eri kirjoittajien artikkeleista koostuva Nuori Otto Vil-

36 Vrt. Eskola, Antti, Toiviainen, Seppo, Alestalo, Matti ja Alapuro, Risto, Marxilainen tutkimus. Teoksessa Suomalaisen sosiologian juuret. Toim. Alapuro, Risto et al. Porvoo 1973, s.197-202 ja Alapuro, Risto ja Alestalo, Matti, Konkreettinen sosiaalitutkimus. Teoksessa Suomalaisen sosiologian historia. Toim. Alapuro, Risto, Alestalo, Matti ja Haavio-Mannila, Elina. Juva 1992, s.89-93.

37 Allardt, Erik. The History of the Social Sciences in Finland 1828-1918. Ekenäs 1997, s.73.

38 Yrjö Koskisen oikea nimi oli Georg Zacharias Forsman. Käytän hänen kirjailijanimenään käyttämää Yrjö Koskista, josta tuli aateloinnin yhteydessä (1882) virallinen sukunimi Yrjö-Koskinen. 
le Kuusinen, 1881-1920 tarjoaa vertailukelpoista aineistoa, kuten myös Jaakko Paavolaisen Tannerin elämäkerran kaksi ensimmäistä osaa.

Gyllingistä on tehty kaksikin elämäkertateosta. Arvo Ylärakkola on kirjoittanut Gyllingistä elämänkertateoksen Edvard Gylling. Itä-Karjalan suomalainen rakentaja. Teos nojautuu vankkaan arkistomateriaaliin, mutta ei täytä tieteellisyyden kriteereitä: faktatietoihin ei voi luottaa, lähdeviittaustekniikka on puutteellinen ja objektiivisuus vaihtuu välillä tutkimuskohteen kritiikittömään ihailuun. Lisäksi teoksen painopiste on tästä tutkimuksesta poiketen sisällissodan jälkeisessä ajassa. ${ }^{39}$ Anna-Lisa Sahlströmin Viimeinen ruhtinas. Kertomus Edvard Gyllingistä on puolestaan kirjoitettu hyvin, mutta varsin kaunokirjallisella otteella, vaikkakin lähteenä käytetään Gyllingin kirjeitä. Kaiken kaikkiaan Sahlström käsittelee kuitenkin varsin vähän Gyllingin tutkimustyötä, torpparikysymyksiä tai edes eduskuntatyötä.

Gyllingin ajattelusta ja toiminnasta on kirjoitettu joitakin yksittäisiä asiantuntevia artikkeleita, kuten Pekka Korpisen kirjoitus Edvard Gylling - sosialisti ja tiedemies sekä varsinkin Sakari Heikkisen ja Tapani Maurasen artikkelit Edvard Gylling suomalaisen yhteiskunnan tutkijana, Edvard Gyllingin elämä ja tieteellinen ura ja Edvard Gylling, yhteiskuntatiede ja historia. Stefan Ek on puolestaan tehnyt Gyllingistä pro gradun Edvard Gylling som samhällsforskare, jossa tehdään joitakin osuvia huomioita hänen tutkimuksistaan ja niiden taustoista. ${ }^{40}$

39 Ylärakkolan teoksesta syntyi Historiallisessa Aikakauskirjassa voimakassanainen keskustelu. Mikko Uola arvosteli sitä varsin kovin sanoin. Hän toi esiin kirjan kronikkamaisuuden ja kriittisyyden puutteen. Ylärakkola puolestaan syytti Uolaa patavanhoillisesta asenteesta. Välittävän kannan otti Seppo Väisänen, joka myönsi tutkimusotteen amatöörimäisyyden, mutta löysi kirjasta myös ansioita ja penäsi Uolalta ymmärtävämpää suhtautumista. Ks. Uola, Mikko, Gylling-kronikka. Historiallinen Aikakauskirja (HAik) 1977, s.180-182; Ylärakkola, Arvo, Gylling-kronikka, HAik 1977, s.360-362; Uola, Mikko, Se koira älähtää..., HAik 1977, s.362-363; Väisänen, Seppo, Gylling ja vallankumous, HAik 1978, s.64-65,

40 Ek, Stefan, Edvardn Gylling som samhällsförskare. Pro gradu. Åbo akademie 1994, erit. s.66-68. 
Heikkinen ja Mauranen korostavat, että 1900-luvun kuluessa muotoutuneen tieteellisen jaottelun pohjalta Gyllingiä voidaan nimittää tilastollisesti suuntautuneeksi yhteiskuntatieteilijäksi. Hänen kirjoituksissaan on historiallisia, sosiologisia, väestötieteellisiä ja taloustieteellisiä elementtejä, joiden pohjana on usein tilastollinen analyysi. ${ }^{41}$ Gyllingin tutkimustyön historiallinen ulottuvuus on toisaalta niin vahva, että hänet on usein luettu klassikoksi nimenomaan talous- ja sosiaalihistorian alalla. ${ }^{42}$ Gyllingin ajattelussa yhdistyi historiallinen näkökulma pyrkimykseen etsiä välineitä ajankohtaisten yhteiskunnallisten ongelmien ratkaisemiseen. Gyllingin tieteellinen työkin liittyi läheisesti kansantaloustieteen historiallisen koulukuntaan, joka oli metodiltaan tilastollista ja luonteeltaan soveltavaa. ${ }^{43}$

Kaiken kaikkiaan Gylling sijaitsi tieteelliseltä otteeltaan ja taustoiltaan kansantaloustieteen historiallisen koulukunnan ja marxilaisuuden välimaastossa, mikä osaltaan tekee hänestä erityisen kiinnostavan tutkimuskohteen. Gyllingin vaikeaa määriteltävyyttä osoittaa sekin, että vuonna 1973 teoksessa Suomalaisen sosiologian juuret hänet sijoitetaan osaksi marxilaista tutkimustraditiota. ${ }^{44}$ Toisaalta myöhemmin tehdyssä versiossa Suomalaisen sosiologian historia hänet sijoitetaan konkreettiseen sosiaalitutkimukseen, mihin myös kansantaloustieteen historiallinen koulukunta katso$\operatorname{taan}^{45}$

Erkki Salomaa on kirjoittanut Gyllingin elämästä artikkelin Tiennäyttäjä 2 -kokoelmateokseen. Artikkelia vaivaa ainakin osittain samat puutteet kuin Ylärakkolan teosta. John H. Hodgson on tehnyt kirjan Edvard Gylling ja Otto Ville Kuusinen asiakirjojen va-

41 Heikkinen - Mauranen 1981, s.54.

42 Heikkinen, Sakari - Mauranen, Tapani, Edvard Gylling suomalaisen yhteiskunnan tutkijana. Teoksessa Edvard Gylling - työväenliikkeen tiedemies. Toim. Heikkinen, Sakari - Mauranen, Tapani, Helsinki 1983 (A), s.19.

43 esim. Heikkinen - Mauranen 1981, s.54.

44 Alapuro - Alestalo - Eskola - Toiviainen 1973, s.197-202.

45 Alapuro, Risto - Alestalo, Matti, Konkreettinen sosiaalitutkimus. Teoksessa Suomalaisen sosiologian historia. Toim. Alapuro, Risto et al. Juva 1992, s.88-93. 
lossa, missä esitellään muutamia Gyllingin kirjoittamia keskeisiä tekstejä ja johdatellaan hänen elämänvaiheisiinsa. Kokoelmavihkoset Edvard Gylling - työväenliikkeen tiedemies ja Edvard Gylling 1881-1991 sisältävät kiinnostavaa tietoa Gyllingin ajattelun ja toiminnan taustoista. Näiden lisäksi Gyllingistä on kirjoitettu joitakin lyhyitä ja pintapuolisia artikkeleita ja lehtikirjoituksia, joiden merkitys tämän tutkimuksen kannalta on vähäinen.

Gyllingistä on kirjoitettu siis kaksi varsin pintapuolista ja osin kaunokirjallistakin elämäkertaa, yksi pro gradu -tutkielma ja joitakin artikkeleita, joista osa on selvästi asiantuntevia. Lisäksi hänen ajatteluaan ja toimintaansa käsitellään yleisemmin erilaisissa historiallisissa tutkimuksissa ja teoksissa. Varsinaista laajaa tieteellistä tutkimusta hänestä ei ole kuitenkaan julkaistu.

Gyllingin asemoiminen sosialidemokraattisen puolueen sisällä edellyttää ymmärrystä työväenliikkeen aatteellisesta keskustelusta, joissa maatalouden kehityksellä ja maatalouspolitiikalla oli tärkeä osa. Tämänkin takana on kuitenkin sosialidemokraattien kansainvälinen aatteellinen debatti, jossa keskiössä oli tulkinta kapitalismin kehityksestä ja siitä johdettavissa olevista parhaista poliittisista ratkaisuista ja menettelytavoista.

SDP:n sisällä oli ennen ensimmäistä maailmansotaa tuntuvia näkemyseroja niistä menettelytavoista, joilla sosialismia parhaiten edistetään. Puolueen vallitsevana linjana oli puhdas marxilainen luokkataisteluoppi, jonka aatteellisena oppi-isänä oli Karl Kautsky ja suomalaisena päätulkitsijana "vanhan työväenliikkeen paavi" Edvard Valpas (1873-1937). Suuntausta alettiin kutsua "siltasaarelaisuudeksi", koska sen keskukseksi muodostui Helsingin Siltasaaressa sijaitseva työväentalo. ${ }^{46}$ Kautskyn mukaan sosialismiin siirtyminen oli mahdollista vasta, kun olosuhteet olivat kehittyneet vallankumoukselliseksi. Tällöin vallankumous olisi ehkä mahdollista toteuttaa rauhanomaisesti. Vallankumouksellista tilannetta odotellessaan siltasaarelaiset kannattivat parlamentaarista toimintaa, mutta vieroksuivat läheistä yhteistyötä porvarien kanssa. Valtalinjan oikealla puolella oli kansallismielinen reformistisempi

46 Soikkanen, Hannu, Edvard Valpas. Teoksessa Tiennäyttäjät 1. Toim. Soikkanen, Hannu. Rauma 1967, s.70. 
linja ja vasemmalla puolella suoraviivaisia vallankumouksellisia virtauksia, joiden asema kentällä oli välillä vahva. ${ }^{47}$

Gylling sijoitetaan yleensä puolueen kautskylaiseen valtalinjaan. ${ }^{48}$ Toisaalta hänen on joskus katsottu kallistuneen maltillisemman oikean siiven suuntaan. ${ }^{49}$ Tätä on perusteltu muun muassa sillä, että Gylling suhtautui aseelliseen vallankumoukseen selvän kielteisesti vielä silloinkin, kun puoluejohdon enemmistö kannatti sitä. Gylling kieltäytyi ensin kansanvaltuuskunnan jäsenyydestä, mutta hän meni kuitenkin lopulta mukaan vedoten solidaarisuuteensa työväenliikettä kohtaan. ${ }^{50} 1900$-luvun alkua paljon tutkineen Hannu Soikkasen mielestä Gylling ei ollut selkeä reformisti, kuten vanhassa työväenliikkeessä ehkä Tanner tai Voionmaa. Toisaalta hän katsoo, että Gylling poikkesi myös Kuusisesta, Sirolasta ja Mannerista, jotka kuuluivat puolueen kautskylaiseen valtavirtaukseen. ${ }^{51}$ Kaiken kaikkiaan arviot Gyllingin sijoittumisesta SDP:n sisäisissä oikeisto-vasemmisto -jaotteluissa ovat jonkin verran ristiriitaisia. Tässä tutkimuksessa peilaan tätä asetelmaa erityisesti maatalouskysymysten osalta.

\section{Kysymyksenasettelu ja sen rajaukset}

Edvard Gyllingin tieteellisen tutkimuksen ja poliittisen toiminnan vahvin yhdistävä tekijä oli maatalouskysymys, jonka sisältönä oli tilattoman väestön ja maanvuokraajien aseman parantaminen.

47 Eri ryhmien eroista ja eri tutkijoiden erotteluista tarkemmin Ehrnrooth Jari, Sanan vallassa, vihan voimalla. Sosialistiset vallankumousopit ja niiden vaikutus Suomen työväenliikkeessä 1905-1914. Historiallisia Tutkimuksia 167. Helsinki 1992, s.94-105, 184-189.

48 Salomaa 1967, 168-169; Heikkinen ja Mauranen 1981, s.55-56; Ehrnrooth 1992, s.112, 267.

49 esim. Hodgson 1974, s.12.

50 Hodgson 1972, s.12; Soikkanen 1975, s.263-264. Samoin menettelivät muutamat muutkin työväenliikkeen johtohenkilöt.

51 KansA, KGS, kansio 1, Hannu Soikkasen alustus aiheesta: Gyllingin aatteellinen kehitys 1903-1918, reformistista vallankumousmieheksi. 
Hänen laajaa lukeneisuuttaan ja tieteellistä taustaansa käytettiin monipuolisesti hyväksi muun muassa eduskunta- ja komiteatyössä sekä torppariliikkeessä. Gyllingiä kiinnostivat myös väestökysymykset. Tässä tutkimuksessa käsitellään niitä siltä osin kuin ne liittyvät selkeästi maatalouteen ja maaseudun oloihin.

Gyllingin tutkiminen auttaa ymmärtämään laajemminkin 1900-luvun alun tieteellistä, aatteellista ja poliittista ilmapiiriä. Tuohon aikaan sijoittuu tieteenhistoriallisesti merkittävä taitekohta, kun yhteiskuntatieteet alkoivat erottua varsinaisista humanistisista tieteistä. Tutkimus auttaa myös ymmärtämään laajemminkin tuolloista tiedemaailman ja politiikan välistä suhdetta. Se oli tuolloin varsin tiivis, pelkästään jo siksi, että useilla Suomen johtavista poliitikoista oli takanaan tieteellinen koulutus.

Gyllingin omaksuma yleinen teoreettinen viitekehys ja hänen aatteelliset painotuksensa ovat tietysti merkityksellisiä hänen maatalouspoliittisille näkemyksilleen ja toiminnalleen. Hänen aatteellista kehystään ja sen muuttumista käsitelläänkin tässä tutkimuksessa melko seikkaperäisesti. Sen sijaan Gyllingin toiminnan Suomen itsenäistymisprosessissa ja käsitykset sisällissotaan liittyvissä menettelytapa-asioissa jätän tutkimuksen ulkopuolelle.

Tutkimuksen aikarajauksen alkupisteeksi on valittu suurlakko, koska se oli erittäin merkityksellinen tapahtuma paitsi koko suomalaiselle työväenliikkeelle, myös Gyllingille. Tuolloin hän aktivoitui toden teolla sosialidemokraattisessa puolueessa - ja alkoi vaikuttaa sen maatalouspolitiikkaan. Tutkimus päättyy sisällissodan alkamiseen, joka muodostaa suurlakkoakin vahvemman murroskauden sekä SDP:n maatalouspolitiikassa että Gyllingin omassa elämässä.

Tutkimuksessani pyrin vastaamaan seuraaviin kysymyksiin valitun aikarajauksen sisällä. Varsinainen pääkysymys on seuraava:

1. Mikä merkitys Edvard Gyllingin maatalouspoliittisilla näkemyksillä ja toiminnalla oli sosialidemokraattisessa puolueessa ja sitä kautta laajemmin yhteiskunnassa? 
Pääkysymystä tukevat seuraavat alakysymykset, jotka auttavat osaltaan siihen vastaamisessa. Alakysymysten merkitys on lähinnä pääkysymystä tukeva ja ymmärrystä syventävä.

2. Mihin tieteellisiin ja poliittisiin lähtökohtiin Gyllingin maatalouspoliittiset näkemykset perustuivat?

3. Miten Gyllingin tieteelliset ja maatalouspoliittiset näkemykset muuttuivat eri tilanteissa ja ajan kuluessa?

4. Miten Gylling käytti tutkimustietoa maatalouspoliittisen toimintansa tukena?

Etenen tutkimuksessa pääosin kronologisesti, joskin paikoitellen käsittelen asioita temaattisesti ja kokoavasti, koska sitä kautta voi paremmin nähdä asioita kokonaisuuksina. Tarkastelen Gyllingin tutkimustyötä rinnakkain hänen poliittisen argumentaationsa ja toimintansa kanssa. Tutkimuksen punainen lanka on Gyllingin näkemys maatalouskysymyksistä ja toiminta maatalouspoliitikkona. Tarkastelen Gyllingin muuta tutkimustyötä ja poliittista toimintaa vain silloin, kun se on tarpeen hänen maatalouspoliittisen ajattelunsa ja toimintansa ymmärtämiseksi. Hänen yksityiselämänsä jätän ainoastaan taustatekijäksi.

Tämän tutkimuksen aikarajaus alkaa suurlakosta ja päättyy sisällissotaan. Nämä molemmat tapahtumat ovat kansallisessa historiassa erittäin merkittäviä virstanpylväitä ja jälkimmäisen himmenevä varjo ulottuu nykyaikaan saakka. Torpparikysymys on myös piirtynyt kansakunnan historiatietoisuuteen ja saanut siinä viimeistään Väinö Linnan Täällä Pohjantähden alla -trilogian myötä keskeisen aseman sisällissodan syntymisen syynä. Tämän tutkimuksen anti liittyy myös siihen, että se avaa torpparikysymystä ja laajemminkin 1900-luvun Suomen maaseudun yhteiskunnallista tilannetta ja epäkohtia. Tämä tutkimus valottaa niitä vahvasti yhden ihmisen ajattelun ja toiminnan näkökulmasta, mutta sitä kautta voidaan peilata laajemminkin aikakauden maatalouden ongelmia ja niitä ratkaisemiseen pyrkivää maatalouspolitiikkaa sekä sitä taustoittavaa tutkimusta. Samalla tämä 
näkökulma korostaa sitä tosiasiaa, että yhteiskunnallinen muutos on aina kiinni yksilöiden yhteisestä toiminnasta.

\section{Tärkeimmät alkuperäislähteet}

Tutkimuksen keskeisimmän lähdepohjan muodostavat Edvard Gyllingin kirjoittamat tutkimukset ja artikkelit. Maanviljelystyöväen taloudellisista oloista Ikaalisten pitäjässä vuonna 1902 valmistui vuonna 1903 maanviljelyksen kansantalous- ja tilastotieteen pro gradu -työnä. Työ ilmestyi painettuna vuonna 1907 Kansantaloudellisen Yhdistyksen julkaisemassa Taloustieteellisiä tutkimuksia -sarjassa.

Selvästi sosiaalipoliittiseen toimintaan Gylling meni mukaan ryhtyessään Invaliditeettivakuutuskomitean tutkijaksi. Komitealle annettiin vuonna 1904 tehtäväksi selvittää työkyvyttömyys- ja vanhuusvakuutuksen järjestämistä. Gylling laati komitealle laajan tilastoihin perustuvan tutkimuksen Väestö-, invaliditeetti ja tulosuhteet Tuusulan, Humppilan, Kymin, Räisälän ja Vihannin kunnissa vuonna 1903. Tutkimus tehtiin kyselykaavakkeiden avulla ja siinä pyrittiin keräämään tiedot kuntien koko väestöstä. Yhteensä lähes 800-sivuinen tutkimus ilmestyi kahtena niteenä vuosina 1906-07. Metodiltaan varsin mekaaninen tutkimus ei kuitenkaan juuri avaa näkökulmaa Gyllingin ajatusmaailmaan.

Gyllingin vuonna 1909 ilmestynyt väitöskirja Suomen torpparilaitoksen kehityksen pääpiirteet Ruotsinvallan aikana käsitteli maatalouskysymyksiä, vaikka suuntautuikin selvästi historiaan. Tutkimuksen näkökulma oli osin taloushistoriallinen, osin oikeushistoriallinen ja paikoin sosiaalihistoriallinen. Myös tässä tutkimuksessa tilastoilla on suuri merkitys. Sen merkitys Gyllingin maatalouspoliittisen ajattelun taustoittajana on suuri.

Gyllingiltä ilmestyi väitöskirjan jälkeen vain yksi varsinainen tutkimus: vuonna 1915 painettu Syntyvyydestä ja väestön lisääntymisestä Helsingissä. Gylling kirjoitti kuitenkin runsaasti artikkeleita, minkä takia hänen tuotantonsa ennen sisällissotaa sisältää 
yli 150 kirjoitusta. ${ }^{52}$ Niissä käsiteltiin monipuolisesti suomalaista yhteiskuntaa sekä historiallisesta lähtökohdista että ajankohtaisista näkökulmista käsin. Osa kirjoituksista on selvästi tieteellisiä, mutta välillä ote on varsin poliittinen. Gylling kirjoitti monista aiheista, mutta maatalouden kysymykset ja maatalouspolitiikka oli kuitenkin hänen tärkein kiinnostuksen kohteensa.

Erilaiset kirjoitukset vaativat vaihtelevia tarkastelu- ja tulkintatapoja. Heikkinen ja Mauranen katsovat, että Gyllingin tuottamat tekstit on jaettavissa kolmeen tyyppiin: käytännön poliittiset kirjoitukset, puhtaasti tieteelliset kirjoitukset sekä historiallisia rinnastuksia aikansa poliittiseen ja yhteiskunnalliseen tilanteeseen sisältävät kirjoitukset. ${ }^{53}$ Luokittelu kuvaa melko osuvasti Gyllingin tuotantoa, joskin se pakostakin on yksinkertaistus.

Gyllingin historiakuvan ja yhteiskuntanäkemyksen selvittämisen kannalta keskeistä aineistoa ovat myös hänen puolueopistossa pitämänsä luennot. Tätä kautta on mahdollista aukaista hänen teoreettista ja historianfilosofista ajatteluaan, jolla oli selkeä yhteys hänen poliittiseen toimintaansa ja mielipiteisinsä maatalousasioiden piirissä.

Gyllingin poliittinen toiminta alkoi Ylioppilaiden Sosialistisessa Yhdistyksessä, jonka kokouksista on valitettavasti säilynyt vain hajanaisia pöytäkirjoja. Erittäin tärkeitä lähteitä ovat sen sijaan painetut SDP:n puoluekokousten ja valtakunnallisten maanvuokraajakokousten pöytäkirjat. Gyllingin roolia SDP:ssä valaisevat kiinnostavasti myös Työväen Arkistossa olevat puoluetoimikunnan ja puolueneuvoston pöytäkirjat.

52 Sakari Heikkinen ja Tapani Mauranen mainitsevat laatimassaan bibliografiassa 154 kirjoitusta ennen sisällissodan alkua. Heikkinen, Sakari - Mauranen, Tapani, Edvard Gyllingin kirjallinen tuotanto 1904-1937. Teoksessa Edvard Gylling - työväenliikkeen tiedemies. Toim. Heikkinen, Sakari - Mauranen, Tapani. Helsinki 1983 (B), s.73-82. Ainakin yksi Gyllingin kirjoitus julkaistiin myös viroksi, nimittäin Soome-teoksessa vuonna 1909 julkaistu laajahko artikkeli Maaküsimus Soomes. Gylling 1909 F. Tätä artikkelia oli tosin täydentänyt virolainen Mihkel Martna. Tästä on lisää Zetterberg, Seppo, Kulttuuria ja kumouspuuhia. Helsingin virolaisyhteisö 1900-luvun alussa. Viro 2013, s.259-260.

53 Heikkinen - Mauranen 1983 A, s.22. 
Gyllingin toiminnasta valtiopäivillä saa parhaan kuvan valtiopäivien asiakirjoista, joita voi tukea SDP:n eduskuntaryhmän toimintakertomuksilla ja pöytäkirjoilla. Näiden dokumenttien kautta hänen käytännön toimintansa maatalouskysymysten parissa avautuu paremmin kuin kirjoituksissa, jotka yleensä olivat kuitenkin joko teoreettisia analyysejä tai maaseudun ihmisille suunnattuja yleiskirjoituksia.

\section{Metodologia}

Tämä tutkimus ei ole aikarajauksen sisälläkään varsinainen elämäkerta, missä kohdehenkilön elämän keskeiset tapahtumat pyrittäisiin selvittämään tyhjentävästi. Kuitenkin tätäkin tutkimusta koskettaa biografisen tutkimuksen klassinen ongelma ympäristön ja yksilön suhteesta. Ongelmaan ei liene yksiselitteistä ratkaisua sen filosofisen perusluonteen takia. Käytännössä useimmat tutkijat pyrkivät noudattelemaan eräänlaista kultaista keskitietä, missä ihminen pyritään saattamaan mahdollisimman kiinteään vuorovaikutukseen ympäröivän maailman kanssa. Biografinen tutkimus voidaan yleisemminkin käsittää ennen kaikkea yksilön ja ympäristön vuorovaikutuksen tutkimiseksi. ${ }^{54}$

Historiantutkimuksen ja elämäkertojen suhde on suhteellisen tiivis vuosisatojen ajan. Aina antiikin ajoista lähtien elämäkertoja on tehty ennen kaikkea "merkittävistä miehistä". Vasta 1900-luvun loppupuolella biografisen tutkimuksen piiriin ovat tulleet ns. tavalliset ihmiset, naiset ja lopulta erilaiset marginaalit ja vähemmistöt. Tämä liittyy erityisesti mikrohistoriallisen näkökulman vahvistumiseen. Välillä historiantutkimuksessa on puhuttu jopa "biografisesta käänteestä", jonka kautta on korostunut yksilöiden ja yhteiskunnan monimutkaiset suhteet. Samalla historioitsijat

54 Uino, Ari, Biografisen tutkimuksen ääriviivoja. Teoksessa Historia nyt. Historiallisen Yhdistyksen julkaisuja 5. Juva 1990, s.305; Sulkunen, Irma, Mandi Granfelt ja kutsumusten ristiriita. Hämeenlinna 1995, s.8-9; Häkkinen, Antti, Johan Adolf Kock, elämäkulkuanalyysi ja historia. HAik 4/2012, s.378-389. 
ovat alkaneet miettiä enemmän sitä, miten elämäkerrannollista tutkimusta olisi hyvä tehdä. ${ }^{55}$

Hannu Soikkanen katsoo, että Gyllingistä luodussa kuvassa on samantyyppisiä myyttisiä aineksia kuin N. R. af Ursinissa (1854-1936). ${ }^{56}$ Gyllingistä ei kuitenkaan ole olemassa yksiselitteistä sankarimyyttiä, jonka kaataminen voisi olla tämän tutkimuksen tarkoitus. Työväenliikkeen myöhemmän historiakuvan kannaltakin hän jäi jotenkin välimaastoon. Sosialidemokraatit eivät tunnustaneet omien esikuviensa joukkoon Neuvosto-Karjalan johtajaa. Kommunisteille hän jäi enemmän tai vähemmän Otto Ville Kuusisen varjoon. Tällaisella tutkimuksella voidaan tarkentaa Gyllingin asemaa ja roolia historiassa.

Gyllingin tutkimustyö oli epäilemättä vankka pohja hänen yhteiskunnallisille näkemyksilleen. Huomattavasti vaikeampi kysymys on, mitä merkitystä niillä oli hänen konkreettisille poliittisille ratkaisuilleen. Kari Palonen hylkää sekä näkemyksen, jonka mukaan yksilön teoreettisilla näkemyksillä olisi mitään merkitystä politiikan sisältöön että myös sen kannan, että poliittinen toiminta olisi johdettavissa suoraan hänen taustafilosofiastaan. Palosen mukaan teoreettinen ajattelu olisi ymmärrettävä poliittisesti toimivan henkilön itsereflektioksi, joka ei vie päätösvaltaa yksilöltä mutta kuitenkin ohjaa politiikan sisältöä, kohdetta, tekotapaa ja

55 Barbara Caine on tehnyt historian tutkimuksen ja elämäkertojen suhteesta kiinnostavan teoksen, jossa näitä asioita käsitellään valaisevasti ja monipuolisesti. Caine, Barbara, Biography and history. Theory and history -series. New York 2010, erit. s. 3-26, 111-114, 122-124.

56 Kansan Arkisto (KansA), Kokoelma Gylling-seminaarista (KGS), kansio 1, Hannu Soikkasen alustus aiheesta: Gyllingin aatteellinen kehitys 19031918. Reformistista vallankumousmieheksi. Soikkanen viitannee tässä Marjatta Rahikaisen tutkimukseen, missä hän osoitti af Ursinista luodun kuvan myyttiseksi ja kestämättömäksi, jolloin "hänen kaltaisensa keskinkertaisuus pääsi historiaan”. Ks. Rahikainen, Marjatta, N.R. af Ursin. Aatelismies Suomen työväenliikkeessä. Historiallisia Tutkimuksia 135, Helsinki 1986, s.308. Soikkanen tosin piti myös tätä luonnehdintaa af Ursinista liian ankarana. Ks. Soikkanen, Hannu, Kuinka pitkälle on ymmärrettävä kohdettaan vai onko häntä arvioitava - elämäkertatutkimuksen haasteita. HAik 4/1987, s.274-275. 
sen käsittämistä koskevia tulkintoja. ${ }^{57}$ Tätä lähestymistapaa pidän paitsi hyvin perusteltuna niin myös tutkimuksellisesti hedelmällisenä.

Markku Hyrkkäsen mukaan aatehistoriallista tutkimusta ohjaa yleensä idea ajattelun ja toiminnan yhteydestä. Eri ihmiset voivat käsittää vallitsevat olosuhteet olennaisesti eri tavoin. Tästä syntyvät erilaiset ajatukset ja mielipiteet, jotka ohjaavat toimintaa. Hän kritisoi varsin perusteellisesti aatehistoriassa usein käytettyä vaikutehistoriallista mallia, jossa selvitetään ihmisen ajattelua siltä pohjalta, keneltä hän on omaksunut käsityksiä ja mitä kautta vaikutteita saanut. Mielestäni Hyrkkänen onnistuu osoittamaan, että tämä on useimmissa tapauksissa liian yksinkertainen ja helppo selitysmalli. ${ }^{58}$

Gylling tulkitsi olosuhteita jollakin tavalla, jonka pohjalta hän valitsi omat toimintamallinsa. Hän sai tietenkin vaikutteita ympäristöstään. Tämän toteaminen ei kuitenkaan riitä, vaan on yritettävä selvittää, miksi hän hyväksyi jotkut vaikutteet ajattelunsa osaksi ja hylkäsi toiset. Mekaanisesta vaikutemallista pitää siis edetä syvemmälle toiminnan ja ajattelun suhteen problematisointiin. Yksilö on kiistatta ajattelussaan ja toiminnassaan riippuvainen ympäröivistä olosuhteista, jotka määrittelevät rajat, joiden sisäpuolella yksilöillä on kuitenkin vaihtoehtoisia toimintamalleja. Gyllingin tieteelliset ja poliittiset näkemykset kehittyivät yhteydessä yhteiskunnalliseen, kulttuuriseen ja tieteelliseen kontekstiin, mutta ne edellyttivät myös subjektiivisia valintoja. Hänellä olisi ollut mahdollisuus toisenlaisiin ratkaisuihin, mutta hän ei olisi kyennyt täysin vapautumaan ympäröivistä ajatusmalleista ja olosuhteista.

57 Palonen, Kari, Retorinen käänne poliittisen ajattelun tutkimuksessa. Quentin Skinner, retoriikka ja käsitehistoria. Teoksessa Pelkkää retoriikkaa. Tutkimuksen ja politiikan retoriikat. Toim. Palonen, Kari ja Summa, Hilkka. Tampere 1996, s.137.

58 Hyrkkänen, Markku, Aatehistorian mieli. Historiallinen Aikakauskirja 4/1989, s.325-327; Hyrkkänen, Markku, Aatehistorian mieli. Jyväskylä 2002., s.137-153. 
Gyllingiä voidaan verrata muihin tiedemiehiin, jotka pyrkivät yhdistämään tieteen ja yhteiskunnallisen ajattelun. Hyvän vertailukohdan antavat Gyllingiä edeltävät vanhasuomalaiset tiedemies-poliitikot, J. R. Danielson (1853-1933, vuodesta 1906 Danielson-Kalmari) ja Hannes Gebhard (1864-1933). Näiden kahden porvarillisen vaikuttajan kanssa Gylling kävi useita kertoja voimakasta debattia.

Koska tämän tutkimuksen keskeiset lähteet ovat Gyllingin kirjoitukset, tekstianalyysi nousee keskeiselle sijalle. Tutkittavan yksilön kirjoituksista pyrin tekstianalyysin avulla löytämään olennaiset asiat ja mahdolliset piilomerkitykset. Onnistuneelle tulkinnalle on tärkeää se, että keskeiset käsitteet ymmärretään tutkimusajankohdasta käsin, eikä tämän päivän merkityksiä siirretä menneisyyteen sellaisenaan, koska niiden merkityssisältö saattaa olla erilainen. Vaikka tämä vaara on erityisen suuri varhaisempien aikojen tutkijalle, saattavat käsitteiden merkityssisällöt muuttua suhteellisen lyhyessäkin ajassa. ${ }^{59}$

Aatehistorioitsija Dominick Lacapra erottelee erilaisia tekstuaalisia konteksteja. Tekstiä voidaan tarkastella suhteessa kirjoittajan aikomuksiin, jolloin yritetään selvittää mitä kirjoittaja halusi sanoa jossakin historiallisessa tilanteessa. Teksti voidaan suhteuttaa myös kirjoittajan elämään tai hänen jälkimaineeseensa, jolloin pitää huomioida kirjoittajan oma kehitys ja muiden kirjoitukset hänestä. Tarkastelukulmaa laajentamalla teksti voidaan suhteuttaa ympäröivään yhteiskuntaan ja kulttuuriin. Lacapra erottelee näiden lisäksi vielä tekstin suhteen ympäröivään diskurssiin. ${ }^{60}$ Suomalaisista historiantutkijoista muiden muassa Jari Ehrnrooth on soveltanut ranskalaisen filosofin Michel Foucaultin (1926-1984) tulkintaa diskurssianalyysistä oppihistoriaan. Ehrnrooth korostaa Foucaultin menetelmien auttaneen luomaan historiantutkimuk-

59 Käsitehistoriallisesta keskustelusta aatehistorian piirissä tarkemmin esim. Mikkeli, Heikki, Aatehistoriasta käsitehistoriaan. Teoksessa Historia Nyt. Näkemyksiä suomalaisesta historiantutkimuksesta. Juva 1990, s.260-263, 276-277.

60 Ks. tarkemmin Lacapra, Dominick, Rethinking Intellectual History: Texts, Contexts, Language. London 1983, s.36-61. 
seen uusia kysymyksenasetteluita ja uudenlaisen tavan jäsentää opillisia tekstejä. ${ }^{61}$ Diskurssianalyysissä teksti nouseekin usein keskeisemmäksi kuin sen "takana" oleva "todellisuus". ${ }^{62}$

Michel Foucaultin käsitettä "diskurssi" on vaikea määritellä täsmällisesti, mutta se liittyy todellisuuden ja siitä esitettyjen lausumien välisen suhteeseen. Hänen yhtenä keskeisenä pyrkimyksenään oli irrottaa lausumat niitä tuottavista yksilöistä, jolloin syntynyt diskurssi käsitetään enemmän jonkun historiallisen tilanteen kuin subjektien oivallusten tulokseksi. Tästä johtuen lausumat voidaan pitkälti palauttaa vallitsevaan diskurssiin. ${ }^{63}$ Kieli ei siis ole sosiaalisen todellisuuden neutraali heijastaja vaan sekä sen tuote että tuottaja. ${ }^{64}$ Kun lausuma esitetään jonkin diskurssin sisällä, diskurssi mahdollistaa sen, että näemme sen jollakin tietyllä tavalla ${ }^{65}$ Diskurssianalyysi voidaan määritellä esimerkiksi seuraavasti: kielen käytön ja muun merkitysvälitteisen toiminnan tutkimista, jossa analysoidaan yksityiskohtaisesti sitä, miten sosiaalista todellisuutta tuotetaan erilaisissa sosiaalisissa käytännöissä. ${ }^{66}$

Diskurssianalyysin kautta avautuu näkökulma sen miettimiseen, mikä osuus Gyllingin ajattelusta perustui tiedeyhteisön paradigmoihin, sosiaalipoliittiseen keskusteluun tai sosialistisiin perusväittämiin. Toisaalta myös Gyllingin kirjoitukset vaikuttivat

61 Ehrnrooth, Jari, Tuottaako uusi näkökulma "uutta historiaa" - esimerkkinä Foucaultin diskurssianalyysin sovellutus oppihistoriaan. Historiallinen Arkisto 93. Toim. Enden, Rauno. Helsinki 1989, s.100-103.

62 Eskola, Jari - Suoranta, Juha, Johdatus laadulliseen tutkimukseen. Jyväskylä 1998, s.197.

63 Foucault, Michel, The Archealogy of Knowledge. Bristol 1989 (alkuteos L, Archélogie du savoir 1969), s.106-125, 199-211; vrt. myös Foucault, Michel, The Order of Things. An Archeology of the Human Sciences. Bristol 1986 (alkuteos Le Mots et les Choses 1966), s.83-88.

64 Eskola - Suoranta 1998, s.141.

65 Koskela, Lasse - Rojola, Lea, Lukijan ABC-kirja. Johdatus kirjallisuuden nykyteorioihin ja kirjallisuudentutkimuksen suuntauksiin. Tietolipas 150. Rauma 1997, s.163.

66 Jokinen, Arja - Juhila, Kirsi - Suoninen, Eero, Johdanto, Teoksessa Diskurssianalyysin aakkoset, Toim. Jokinen, Arja et al.., Tampere 1993, s.9. 
ympäröivään diskurssiin ja sitä kautta tuohon käytännön elämään eli "todellisuuteen".

Diskurssianalyysi on kuitenkin vain väljä teoreettinen viitekehys, jonka soveltaminen riippuu tutkimuskohteesta. ${ }^{67}$ Sen yksityiskohtainen soveltaminen Gyllingin lausumiin on vaikeaa. On kuitenkin hedelmällistä huomioida hänen kannanottonsa osana laajempaa diskurssia, millä on tiivis yhteys yhteiskunnalliseen todellisuuteen. Samalla on syytä tarkastella sitä, kuinka paljon Gyllingin kulloinkin käyttämään kirjoitusmuotoon ja -tyyliin vaikutti se, mille kohderyhmälle teksti oli ensisijaisesti suunnattu.

Saksalaiset käsitehistorioitsijat ja erityisesti Reinhart Koselleck ovat keskeisiä käsitehistoriallisen ajattelun ja menetelmien jäsentämisessä. Koselleck lähtee siitä keskiajan realistien näkemyksestä, että käsitteet ovat yhtä todellisia kuin asiat. Näin ollen käsitteiden tutkimus on niiden sisältämien kasautuneiden kokemuksien tutkimista. Kokemusten tutkimus johdattaa tutkimaan niiden sosiaalisia edellytyksiä. ${ }^{68}$ Koselleckin mukaan käsitteiden moniselitteisyys tekee niistä usein ongelmallisia. Tästä hyvä esimerkki on moniin erilaisiin yhteyksiin liitetty käsite "vallankumous"; voidaan puhua teollisesta vallankumouksesta, sosialistisesta vallankumouksesta, kulttuurivallankumouksesta ja jopa vallankumouksellisesta valtiosta. ${ }^{69}$ Koselleck on yhdessä Otto Brunnerin ja Werner Conzen toimittanut massiivisen seitsenosaisen teoksen Geschichtsliche Grundbegriffe, missä 150 tutkijan voimin analysoidaan historian peruskäsitteitä. Käsikirjan toimitustyötä ohjaavana hypoteesina on ollut, että Eurooppa oli modernin kynnyksellä vuosina 1750-1850. Tänä aikana poliittis-sosiaaliset peruskäsitteet muuttuivat modernille ihmiselle tutuiksi käsitteiksi. ${ }^{70}$ Suoma-

67 Jokinen, Arja - Juhila, Kirsi - Suoninen, Eero, Diskursiivinen maailma. Teoreettisen lähtökohdat ja analyyttiset käsitteet. Teoksessa Diskurssianalyysin aakkoset. Toim. Jokinen, Arja et al., Tampere 1993, s.17-18.

68 Hyrkkänen, Markku, Reinhart Koselleck - sosiaali- ja käsitehistorioitsija. Haik 4/1994, s.331-332.

69 Koselleck, Reinhart, Futures past. On the Semantics of Historical Time. London 1985 (alkuteos Vergangene Zukunft 1979), s.39-51.

70 Hyrkkänen 1994, s.331-332. 
laisesta käsitehistoriallisesta tutkimuksesta voidaan mainita kokoelmateos Käsitteet liikkeessä, jossa analysoidaan monia Suomen historian keskeisiä käsitteitä ja niiden muutoksia historiallisessa pitkittäiskatsauksessa.

Gyllingin maatalouspolitiikassa käyttämien keskeisten käsitteiden analyysi ja niiden vertaaminen ajankohdan keskustelussa vallitseviin käsitteisiin on tutkimukseni kysymyksenasettelun kannalta hedelmällistä. Samalla tarkastelen sitä, muuttuuko näiden käsitteiden merkitys ajan kuluessa ja miten, vaikkakin tämä tutkimus käsittelee suhteellisen lyhyttä ajanjaksoa. Tätä kautta jäljitän yleisemmin Gyllingin maatalouteen liittyvissä näkemyksissä tapahtuneita muutoksia ja sitä, mihin teoreettiseen viitekehykseen ne kulloinkin pohjautuivat. Tällaisen käsitteellisen tarkastelun kautta voin hahmottaa sitä, erosiko sosialistinen ajattelu porvarillisesta jo käsitteiden tasolla. On kuitenkin huomattava se, etteivät käsitteet ainakaan aina ole tietoisia valintoja, vaan erilaisista teksteistä ja diskursseista itsestäänselvyyksinä otettuja. Gyllingin maatalouskysymykseen liittyviä keskeisiä käsitteitä olivat esimerkiksi seuraavat: "maanomistajat", "maanvuokraajat", "torpparit", "(maalais)köyhälistö", "tilaton väestö", "viljelyspakko", ja "pienviljelys". Maatalouskysymyksestä Gylling kirjoitti historiallisesti asiaa lähestyneen väitöskirjansa lisäksi myös lukuisia artikkeleita, joista näitä käsitteitä voidaan analysoida.

Lähestyn tutkimusaihetta ja -kysymyksiä tapahtumahistoriallisesta näkökulmasta, johon kuitenkin kytkeytyy vahva aatehistoriallinen ote. Tämä on perusteltua, koska Gyllingin maatalouspoliittiset mielipiteet avautuvat ennen kaikkea teorian ja käytännön yhdistämisen kautta. Tässä keskeistä oli keskustelu, jota maatalouskysymyksistä ja -politiikasta käytiin sekä kirjallisesti että suullisesti. Erityisen tärkeitä ovat Gyllingin maatalouspolitiikasta kirjoittamat tekstit, joita tarkastelen kolmella eri tasolla eli (1) suhteessa toisiinsa, (2) suhteessa muiden maatalouskysymysten asiantuntijoiden ja maatalouspoliitikkojen kirjoituksiin sekä (3) suhteessa niiden tieteellisiin ja poliittisiin taustateorioihin ja -oletuksiin. Samalla analysoin näissä viitekehyksissä esiintyviä diskursseja ja käsitteitä. 
Yhtäältä tutkimuksen metodinen ote lähestyy Irma Sulkusen Miina Sillanpäätä tutkiessaan määrittelemää toimintaelämäkertaa, jossa painopiste on yleisen ja yksityisen vuorovaikutuksen tarkastelussa eli siinä, miten yhteiskunnallisten rakenteiden ja tilanteiden muutokset tuovat yksilön eteen uusia tehtäviä ja määräävät hänen toimintaansa - ja toisaalta, kuinka yksilö toiminnallaan muovaa noita rakenteita ja samalla koko historian kulkua. Sulkunen tutkii ensisijaisesti Sillanpään julkista yhteiskunnallista keskustelua eli hänen poliittista toimintaansa ja rooliinsa työväenliikkeen ideologian määrittäjänä, jolloin hänen yksilöllinen elämänkaarensa jää alisteiseksi suhteessa suuriin yhteiskunnallisiin linjoihin..$^{71}$

Pyrin tässä tutkimuksessa noudattamaan kahta Jorma Kalelan hyvin muotoilemaa eettistä periaatetta. Ensinnäkin tutkijan on tiedostettava yhteiskunnallinen vastuunsa ja autettava ihmisiä ymmärtämään maailmaa historian avulla, mikä taas tukee heidän omaa elämänhallintaansa. Toiseksi tutkijan on tehtävä oikeutta tutkimuksen kohteena oleville ihmisille, eli tässä tapauksessa erityisesti Edvard Gyllingille, mutta myös muille ajankohdan toimijoille. Tutkijan on pyrittävä tavoittamaan tutkittavien ihmisten ajatusten ja toiminnan takana olevat tekijät, mutta se ei saa tapahtua sivuuttamalla heidän itseymmärryksensä. ${ }^{72}$

Kaiken kaikkiaan lähestyn tässä tutkimuksessa Gyllingiä toimintaelämäkertaa muistuttavalla otteella, jolloin hänen yksilöllinen elämänkaarensa nähdään maatalouspoliittisten rakenteiden, tilanteiden ja tavoitteiden kautta. Tämän takia jälkimmäisistä

71 Sulkunen, Irma, Naisen kutsumus. Miina Sillanpää ja sukupuolten maailmojen erkaneminen. Juva 1989, s. 11-12; Rakenteen ja yksilön vuorovaikutusta on hyvin problematisoinut myös esim. Karonen, Petri, Patruunat ja poliitikot. Yritysjohtajat taloudellisina ja poliittisina toimijoina Suomessa. Historiallisia tutkimuksia 217. Helsinki 2004, s.20-21; Yksilön teoreettisen tutkimustyön vaikutusta hänen poliittisiin linjauksiinsa analysoi kiinnostavasti myös Niskanen, Kirsti, Kvinnopolitiskt engagemang i könsneutral vetenskap - Karin Kocks könsteoretiska analys under 1930-talet. Kvinnovetenskaplig tidskrift 3-4/2001, s.101-117.

72 Kalela, Jorma, "Jatkomenoinen uudistaminen". Politiikka historiassa ja historiantutkimuksessa. HAik 3/2005, s.296. 
muodostuu tutkimuksen punainen lanka edellisen jäädessä taustalle. Metodologisina välineinä Gyllingin maatalouspoliittisten näkemysten, toiminnan ja niiden merkityksen avaamiseen käytän vertailevaa tekstianalyysiä ja käsiteanalyysiä, joita tarkastelen suhteessa eri diskursseihin ja tilanteisiin. 


\section{Tie tutkijaksi}

\section{Ajattelun taustatekijät}

Suomalaisen sivistyneistön maailmankuvan keskeisenä pohjana oli 1800-luvun loppupuolella saksalainen idealistinen filosofia, joka oli huipentunut Friedrich Hegelin (1770-1831) ajatteluun. Suomessa hegeliläisyys vaikutti J. V. Snellmanin soveltamana voimakkaasti sekä kansallisuusajatteluun että kulttuurielämään ja tieteeseen. ${ }^{73}$ Snellmanin perintöä jatkoivat muun muassa Yrjö Koskinen ja Zacharias Topelius, joiden välityksellä hegeliläinen filosofia hallitsi suomalaista tiedeyhteisöä 1800-luvun loppupuolelle asti. Vähitellen hegeliläisyyden asema alkoi kansainvälisesti heikentyä, kun luonnontieteet alkoivat kehittyä voimakkaasti, mikä mahdollisti yhteiskuntien teollistumisen. Suomessa hegeliläisyyden väistymiseen oli myös kansallisia syitä. Se oli sopinut hyvin suomen kielen aseman parantamiseen. Viimeistään vuoden 1902 kieliasetuksen jälkeen tämä kävi kuitenkin entistä tarpeettomammaksi, koska sillä alkoi olla valta-asema maassa. ${ }^{74}$

1800-luvun loppupuolen yhteiskunnallinen murros synnyttikin uusia filosofisia ja tieteellisiä näkökulmia ja kysymyksenasetteluita, joita alkoi tulla Euroopasta Suomeen. Uusista suuntauksista merkittävimpiä olivat ranskalaisen Auguste Comten (1798-1857)

73 Manninen, Juha, J. V. Snellman - Aatteet ja elämä. Teoksessa J. V. Snellman ja nykyaika. Toim. Huovinmaa, Kai. Helsinki 1981, s.19-20; Todella monipuolisesti Snellmanin ajattelua käsittelee Tuija Pulkkinen teoksessaan Valtio ja vapaus. Jyväskylä 1989.

74 Jussila, Osmo, Suomalaisuusliike Venäjän paineessa vuosina 1890-1917. Teoksessa Herää Suomi. Suomalaisuusliikkeen historia. Toim. Tommila, Päiviö, Jyväskylä 1989, s.141-143. 
luoma positivismi ${ }^{75}$, Charles Darwinin (1809-1892) kehittämä evoluutioteoria ${ }^{76}$ ja kansantaloustieteen historiallinen koulu, josta tuli Gyllingin ajattelun tärkeä taustatekijä.

Varsinaiset yhteiskuntatieteet eivät olleet vielä eriytyneet omiksi tieteenaloikseen 1800 - ja 1900-lukujen vaihteessa, mutta erityisesti historiantutkimuksessa alettiin tutkia entistä enemmän taloudellisia ja sosiaalisia rakenteita. Päiviö Tommila jakaa tämän yhteiskuntahistorian läpimurron kolmeen rinnakkain vaikuttaneeseen suuntaukseen. ${ }^{77}$ Ensimmäiseen suuntaukseen kuuluivat 1870-luvulta 1890-luvulle tehdyt lähinnä 1500- ja 1600-lukua käsitelleet tutkimukset, joille oli ominaista sidonnaisuus kameraaliseen lähdeainekseen, kuvaileva tilastollinen ote ja suppeahko näkökulma. ${ }^{78}$ Toisena vaiheena oli 1800 -lukuun ja lähimenneisyyteen kohdistunut konkreettinen sosiaalitutkimus. Kolmannen aallon muodosti saksalaisen Karl Lamprechtin (1856-1915) kehittämä kollektivistinen kulttuurihistoria. ${ }^{79}$

75 Comte katsoi, että ihmistieteiden tulisi metodisesti jäljitellä voimakkaasti edistyneitä luonnontieteitä. Hän vaati teoreettisten hypoteesien käyttöä myös yhteiskunnallisissa ilmiöissä, jotta ihmistieteissäkin löydettäisiin yleisiä lainalaisuuksia. Positivismia kehittivät edelleen mm. ranskalainen Hippolyte Taine ja englantilainen Henry Thomas Buckle. Ks. tarkemmin esim. Thompson, Kenneth, Auguste Comte. The Foundation of Sosiology. London 1976, erit. s.87-115 ja Iggers, Georg, G., New Directions in European Historiography. Revised Edition. Middletown 1984, s.33-34.

76 Darwin esitteli vuonna 1859 teorian, minkä mukaan korkeammat lajit olivat kehittyneet alemmista lajeista. Ihminenkin oli vähitellen kehittynyt maapallon yksinkertaisimmista ja alkeellisimmista elämänmuodoista. Darwinin kehitysoppi aiheutti maailmankatsomuksellisen murroksen, koska useat katsoivat sen olevan ristiriidassa Raamatun luomiskertomuksen kanssa. Ks. esim. Gillespie, Neal C., Charles Darwin and the Problem of Creation. Chicago 1979, s.146-156.

77 Tommila, Päiviö, Suomen historiankirjoitus. Tutkimuksen historia. Porvoo1989, s.138.

78 Kameraalisen tutkimuksen tärkein suomalainen kehittäjä oli E. G. Palmén, joka arvosti induktiivista metodia ja tilastotiedettä hyväkseen käyttävää taloushistoriaa. Kukkonen, Jukka-Matti, E. G. Palmén historioitsijana. Pro gradu. Turun yliopisto 1976, s.27,100-101.

79 Lamprechtin ajatuksista saivat vaikutteita mm. historioitsijat Väinö Voionmaa ja Gunnar Suolahti sekä myöhemmin yhteiskuntatieteisiin siirtyneet 
Gyllingin kannalta näistä merkityksellisin oli suuntaus, joka myöhemmin nimettiin konkreettiseksi sosiaalitutkimukseksi. Sen opillisena pohjana oli kansantaloustieteen historiallinen koulukunta, erityisesti sen nuorempi siipi, jota tässä tutkimuksessa esitelleen myöhemmin tarkemmin. ${ }^{80}$ Toinen Gyllingille tärkeä suuntaus, marxilainen tutkimusote, sai Suomessa jonkinlaista jalansijaa vähitellen 1900-luvun ensimmäisinä vuosikymmeninä. ${ }^{81}$

Suomen aatteelliset syvävirtaukset olivat edellä kuvatun kaltaisessa liikkeessä, kun Edvard Gylling syntyi Kuopiossa vuonna 1881. Vaikka hänen perheensä oli ruotsinkielinen, lapset laitettiin suomenkielisiin kouluihin, koska vanhemmat halusivat, että he oppisivat hyvin suomea. Edvard Gylling aloitti kouluopintonsa vuonna 1891 Viipurissa. Gyllingit muuttivat kuitenkin pian Jyväskylään, jolloin perheen lapset siirtyivät sinne kouluun. "Eetti" kirjoittautui Jyväskylän lyseoon lukuvuonna $1892 .{ }^{82}$ Jyväskylän lyseota pidettiin varsin korkeatasoisena kouluna. Sen oppilaista oli vuosisadan lopulla noin kolmannes virkamiesten ja muun sivistyneistön poikia. Myös oppilaita, joiden isä toimi kaupan, teolli-

Ernst Nevanlinna ja K. R. Brotherus. Ks. Jussila, Petri, Lamprecht-keskustelu Suomessa 1800- ja 1900-lukujen vaihteessa. Pro gradu. Jyväskylä 1995, s.88-90, 95, vrt. myös Ahtiainen, Pekka, Kulttuuri, yhteisö, yksilö, Gunnar Suolahti historiantutkijana. Historiallisia tutkimuksia 162. Vammala 1991, s.48-51; Vuosisadan vaihteen lähestyessä J. R. Danielson-Kalmari alkoi myös painottaa entistä selvemmin talous- ja sosiaalihistoriallisia näkökulmia ja toi esiin myös Lamprechtin ajatuksia, vaikkakaan ei niitä kaikilta osin hyväksynyt. Tervonen, Jukka, J. R. Danielson-Kalmari, Historiantutkija ja -opettaja. Historiallisia Tutkimuksia 163. Helsinki 1991, s.50, 100. 180-181.

80 Suomen konkreettisesta sosiaalitutkimuksesta tarkemmin Alapuro - Alestalo 1992, s.77-148.

81 Alapuro, Risto, Marxilaisesta yhteiskuntatutkimuksesta Suomessa vuosisadan alkupuolella. Tiede ja edistys 2/1977, s.15.

82 Vuonna 1992 lyseoon tuli myös Edvardia vajaa kaksi vuotta vanhempi Axel. Vuonna 1894 lyseoon kirjoittautui Edvardia kaksi vuotta nuorempi Uno Ossian ja kaksi vuotta myöhemmin oli viisi vuotta nuoremman Richardin vuoro. Jyväskylän lyseon oppilasmatrikkeli. Teoksessa Jyväskylän lyseo 1858-1983. Toim. Mikkola, Eero. Jyväskylä 1983, s.123, 125, 129. 
suuden ja liikenteen piirissä, oli runsaasti. ${ }^{83}$ Piiri-insinöörin poika Edvard Gylling sopi joukkoon mainiosti.

Vuonna 1883 klassillisten lyseoiden rinnalle oli luotu reaalilyseot. Klassillisissa lyseoissa opetettiin latinaa, kreikkaa ja logiikkaa, kun taas reaalilyseoissa opetettiin niiden sijasta englantia, kemiaa ja piirustusta. ${ }^{84}$ Jyväskylän lyseo kuului klassillisiin lyseoihin. Klassillisten luokkien kolmannen ja neljännen luokan oppilailla oli mahdollisuus vaihtaa reaalilinjalle, jos paikkakunnalla ei ole reaalilyseota eikä neliluokkaista alkeiskoulua. ${ }^{85}$ Valtaosa Jyväskylän lyseon oppilaista sijoittui kuitenkin klassilliselle linjalle - kuten kaikki Gyllingin pojat. ${ }^{86}$

Vuonna 1892 lyseoon kirjoittautui Edvard Gyllingin lisäksi 38 muuta oppilasta. Tulijoiden keski-ikä oli noin 11,5 vuotta ja ikähaitari ulottui kahdeksasta kahteenkymmeneen vuoteen. Edvard oli kymmenen vuoden ja kahdeksan kuukauden ikäisenä hieman alle joukon keski-iän. ${ }^{87}$ Edvard Gylling, Otto Ville Kuusinen ja Martti Kovero (1882-1955) olivat alusta lähtien samalla luokalla. Sulo Wuolijoki tuli lyseoon kolme vuotta myöhemmin, mutta oli suorittanut Hämeenlinnassa aiemmin kolme luokkaa. Wuolijoki, Gylling ja Kuusinen olivat syntyneet vuonna 1881, kun taas Kovero oli syntynyt vuonna 1882. Sulo Wuolijoen muistelmissa mainitaan nelikon olleen hyviä ystäviä lyseoaikoina, kuin "kol-

83 Sinivaara, Eero, Jyväskylän lyseon opinkäynti vv.1858-1908. Teoksessa Jyväskylän lyseon satavuotishistoria 1858-1958. Toim. Oksala, Päivö. Jyväskylä 1958, s.265-270.

84 Kiuasmaa, Kyösti, Oppikoulu 1880-1980. Oppikoulu ja sen opettajat koulujärjestyksestä peruskouluun. Oulu 1982, s.25-26.

85 Jalkanen, K. J., Jyväskylän lyseo 1858-1908. Teoksessa Jyväskylän lyseon satavuotishistoria 1858-1958. Toim. Oksala, Päiviö. Jyväskylä 1958, s.75.

86 Merkittävimpiä poikkeuksia on vuonna 1891 reaalilinjalle kirjoittautunut Rudolf Holsti, joka maailmansotien välillä oli johtavia suomalaispoliitikoita. Suoritettuaan reaalilinjan Holsti siirtyi Helsingin Suomalaiseen Reaalilyseoon ja valmistui sieltä ylioppilaaksi vuonna 1901. Pietiäinen Jukka-Pekka, Rudolf Holsti, Lehtimies, tiedemies, poliitikko 1881-1919. Espoo 1986, s.27-29, 36.

87 Jyväskylän lyseon oppilasmatrikkeli. Teoksessa Jyväskylän lyseo 1858-1983. Toim. Mikkola, Eero. Jyväskylä 1983, s. 123-127. 
me muskettisoturia ja d Artagnan". ${ }^{88}$ Koverosta tuli myöhemmin Tilastollisen Päätoimiston johtaja, kun muista tuli merkittäviä sosialidemokraattisia poliitikkoja.

Monissa arvioissa on korostettu Gyllingin läheistä suhdetta Kuusiseen. ${ }^{89}$ Väitteen uskottavuutta heikentää, ettei Kuusista mainita lainkaan Edvard Gyllingin tai hänen veljiensä Jyväskylästä Ikaalisiin lähettämissä kirjeissä. Kovero sen sijaan mainitaan. ${ }^{90} \mathrm{On}$ mahdotonta todentaa, missä vaiheessa Gylling ystävystyi Kuusisen, Koveron ja Wuolijoen kanssa ja olivatko he hänen parhaat ystävänsä lyseossa. Varsinkin Kuusisen merkitys saattaa korostua liikaa myöhempien tapahtumien kautta tulkittuna.

Jyväskylän lyseon oppilaiden toverikunnan lehti Oras ilmestyi muutaman kerran vuodessa. Oraassa oli oppilaiden kirjoituksia ja runoja eri aiheista. Lehden yleissävy oli kansallisromanttinen ja arvokonservatiivinen. Aivan 1800-luvun lopulla lehteen tuli entistä enemmän sosiaalisia kirjoituksia, joissa kuvattiin muun muassa maaseudun asukkaiden kovaa taistelua luontoa vastaan, oloja vaivaistalossa ja työmiehen asemaa. ${ }^{91}$

Näiden kirjoitusten taustalla on se, että tuolloin Suomessa nousivat voimakkaasti esiin sosiaalipoliittiset kysymykset - erityisesti työväenkysymys ja maatalouskysymys. Suomalaisen Puolueen johtaja Yrjö Koskinen pyrki ajamaan sosiaalisia uudistuksia ja samalla estämään marxilaisen sosialismin leviämisen Suomeen. ${ }^{92}$

88 Wuolijoki, Sulo, Vaari muistelee. Pori 1954, s.61, 66.

89 KA, Arvo Ylärakkolan kokoelma (AYK), kansio 2, Seija Mannisen tekemät haastattelut. Edvard Gyllingin sisar Margit Gylling ja Arvo "Poika” Tuominen väittävät, että Gylling ja Kuusinen olivat jo Jyväskylän lyseossa paljon yhdessä.

90 KansA, KGS, kansio 1, Pentti Papusen luentomuistiinpanot aiheesta: Kalmaan Gyllingin kirjekokoelma.

91 Jyväskylän Maakunta-arkisto (JMA), Jyväskylän Lyseon kokoelma (JLK), esim. Oras 7.4.1894, 15.9.1894 ja 10.11.1895; vrt. Aalto, A., Oras vuosina 1890-1902. Teoksessa Jyväskylän lyseon satavuotishistoria 1858-1958. Toim. Oksala, Päiviö. Jyväskylä 1958, s. 434-437.

92 Koskinen kiinnitti huomiota sosiaalisiin ongelmiin kuuluisassa artikkelisarjassaan "Työväenseikka". Perusteellinen artikkelisarja julkaistiin vuoden 1874 Kirjallisen Kuukausilehden numeroissa 1,4,8 ja 9. Ks. tarkemmin Kos- 
Puolueen linjaksi muodostui konservatiivinen sosiaalireformismi. ${ }^{93}$ Suomalaisen työväenliikkeen kehittämistä porvarilliselta pohjalta jatkoi pienteollisuudenharjoittaja Viktor Julius von Wright (1856-1934). Hän kannatti valtion johtamia sosiaalipoliittisia uudistuksia ja äänioikeusuudistusta, mutta ei yleistä ja yhtäläistä äänioikeutta. ${ }^{94}$ Gylling ei ilmeisesti toiminut aktiivisesti toverikunnan piirissä. Muut Sulo Wuolijoen mainitsemasta nelikosta olivat aktiivisempia. Wuolijoki kirjoitti lehteen jonkin verran suorasanaisia juttuja, kun taas Kuusinen kirjoitti lehteen runsaasti romanttisia ja isänmaallisia runoja. Kovero puolestaan toimi toverikunnan rahastonhoitajana. ${ }^{95}$

Edvard Gylling oli ensimmäisestä luokasta alkaen luokkansa parhaita. Kovimmat kilpailijat olivat aluksi Mooses Laukkanen (1880-1948) ja Matti Rossi (1878-1921). ${ }^{96}$ Kuusisen ja Koveron menestys oli aluksi varsin keskinkertaista, mutta vähitellen he nousivat luokan parhaimmistoon. Gylling vakiinnutti viimeisinä lyseovuosina asemansa luokan parhaana. ${ }^{97}$ Hänen lukuaineiden-

kimies, Rafael, Y. S. Yrjö-Koskisen elämä II. Nuijamieheksi luotu. Keuruu 1974, s.285-288.

93 Eräsaari, Risto - Rahkonen, Keijo, Johdanto. Teoksessa Työväenkysymyksestä sosiaalipolitiikkaan, Tapiola 1975 s.15-19,23-25; Suuntauksen kilpailijana oli liberalistinen sosiaalireformismi, mikä pyrki vahvistamaan kansalaisyhteiskunnan vapaita yhteenliittymiä, kuten osuuskuntia, kulttuuriorganisaatioita ja ammattiyhdistyksiä. Se kuitenkin hävisi valtion merkitystä painottavalle uudistuspolitiikalle, josta tuli Suomessa vallitseva suuntaus. Tästä tarkemmin Turunen, Ilkka, Ammattiyhdistysutopia. Vuosisadan vaihteen liberalistista yhteiskuntapolitiikkaa. Teoksessa Kansa liikkeessä. Toim. Alapuro, Risto et al., Vaasa 1987, s.197.

94 Soikkanen 1975, s.19-21.

95 JMA, JLK, Oras vuosilta 1890-1902; vrt. Pakkanen, Martti, Kyläräätälin poika. Teoksessa Nuori Otto Ville Kuusinen 1881-1920. Toim. Salminen, Vesa. Jyväskylä 1970, s.17-18.

96 Laukkasesta tuli myöhemmin Jyväskylän lyseon Venäjän ja Ruotsin opettaja sekä vararehtori. Rossi toimi myöhemmin mm. Terijoen yhteiskoulun Venäjän opettajana ja johtajana.

97 JMA, JLK, koulutodistukset. Lyseossa saatiin sekä käytöksestä että ahkeruudesta ja tarkkaavaisuudesta arvosana neljän ja kymmenen välillä. Muista aineista lukuun ottamatta laulua ja voimistelua laskettiin lukuaineiden kes- 
sa keskiarvo liikkui ensimmäisinä vuosina yhdeksän molemmin puolin, mutta nousi vähitellen lyseon edetessä. Viimeisessä päästötodistuksessa keväällä 1900 se oli jo 9,6. Tämä oli ylivoimaisesti luokan paras, sillä seuraavaksi korkein keskiarvo oli Koveron 9,1. ${ }^{98}$ Gyllingin koulumenestyksestä piirtyy kuva monipuolisesti lahjakkaasta, ahkerasta ja kunnianhimoisesta nuorukaisesta.

Gyllingin Jyväskylän lyseossa kirjoittamia aineita on säilynyt viidenneltä luokalta lähtien. Gylling kirjoitti paljon historiallisia aineita, mikä saattoi johtua arvostetun historianopettajan, tohtori O. A. Forsströmin (1856-1910, vuodesta 1906 Hainari) vaikutuksesta. Forsström oli väitellyt Inkerinmaan oloista Ruotsinvallan aikana sekä kirjoittanut muun muassa Suomen keskiajan historian, kuvauksen Ruotsin suurvalta-ajasta ja toimittanut oppikirjoja kansakouluille. Forsström oli myös yhteiskunnallinen vaikuttaja. Hän oli pappissäädyn valtiopäivämies vuosina 1899, 1900 ja

kiarvo, jota kutsuttiin edistyksen keskiarvoksi. Lopullinen menestys määriteltiin laskemalla yhteen arvosana käytöksestä, arvosana ahkeruudesta ja tarkkaavaisuudesta sekä edistyksen keskiarvo. Paras mahdollinen tulos oli siis 30. Yleensä menestyvät oppilaat saivat sekä käytöksestä että ahkeruudesta ja tarkkaavaisuudesta kymmenen, jolloin ratkaisevaa oli lukuaineiden keskiarvo. Kahtena ensimmäisenä vuotena Gyllingin mahdollisuudet luokan parhaaksi vei se, että hän sai ahkeruudesta ja tarkkaavaisuudesta arvosanaksi yhdeksän. Kolmannelta luokalta lähtien numero oli jatkuvasti kymmenen.

98 JMA, JLK, koulutodistukset. Lyseossa keskeisin aine oli latina ja kieliä opetettiin yleensäkin varsin paljon. Gyllingillä ei heikkoja aineita juuri ollut. Hän sai yleensä kiitettäviä arvosanoja uskonnosta ja kirkkohistoriasta, historiasta, matemaattisista aineista (luvunlasku ja algebra sekä trigonometria ja geometria), luonnontieteistä (kasvitiede ja eläintiede), vieraista kielistä (ruotsi, saksa, venäjä, ranska ja latina) ja ruotsinkielisyydestään huolimatta suomen kielessä. Sen sijaan suomen kirjoituksessa oli aluksi pieniä vaikeuksia numeroiden ollessa useita vuosia joko seitsemän tai kahdeksan. Kahdeksannella eli viimeisellä luokalla numero oli kuitenkin jo noussut kymmeneen. Gyllingin heikoin aine oli latinan kirjoitus, missä hänen numeronsa oli yleensä seitsemän. Edistyksen keskiarvon ulkopuolella olevissa laulussa ja voimistelussa hän sai arvosanaksi lähinnä kahdeksaa ja yhdeksää; KA, EGK, kansio 3. 
1904-1905 sekä vanhasuomalainen kansanedustaja vuoden 1908 toisilla ja vuoden 1909 molemmilla valtiopäivillä. ${ }^{99}$

Gylling historiallisissa aineissa heijastuvat tietysti ajan yleiset käsitykset ja oppikirjojen antama kuva. Tämä näkyy esimerkiksi aineessa Patriisien ja plebeijien välinen taistelu vanhasta Roomas$t a$, jossa hän kuvaa kehitystä samantyyppisesti kuin Yrjö Koskinen teoksessaan Johtavat aatteet ihmiskunnan historiassa. ${ }^{100}$ Toisessa aineessaan Gylling katsoo Kustaa III:n olleen joistakin virheistä huolimatta Ruotsin suurimpia hallitsijoita, koska hän kohotti maan sekasorron tilasta ja lopetti puolueriidat. ${ }^{101}$ Yrjö Koskinen korostaa myös Suomen kansan historiassa Kustaa III:n merkitystä kansan yhtenäistäjänä. Koskisen esitys Kustaa III:n toiminnasta on kaksijakoinen. Hänen mukaansa hallituskauden alkupuoli oli myönteistä aikaa, mutta loppupuoli kielteistä aikaa. ${ }^{102}$

Keisari antoi helmikuussa 1899 venäläistämispolitiikkaa kiihdyttävän manifestin, mikä aiheutti suomalaisissa vastustusta, joka huipentui niin sanotun suuren adressin keräämiseen. ${ }^{103}$ Gyllingin kahdeksannella luokalla kirjoittamasta aineesta Englannin siirtomaavallan kehittyminen voi löytää yhtymäkohtia ajan poliittiseen

99 Relander, O., O. A. Hainari, muistelmia. Kansan valistusseuran toimituksia 175. A-sarja n:o 1., Helsinki 1917, s.40-43; vrt. Jalkanen 1958, s.72, 87-88. Edellisissä korostetaan, että Forsström oli epämuodollinen ja kaavoihin kangistumaton opettaja, joka saavutti oppilaidensa luottamuksen ja kunnioituksen. Tämän kaltaisiin populaariteoksissa oleviin luonnekuvauksiin on suhtauduttava varauksin. Kuitenkin myös hänen myöhempi poliittinen vastustajansa Sulo Wuolijoki antoi muistelmissaan historianopettajastaan erittäin myönteisen vaikutelman kutsuen häntä "Suomen parhaaksi historian opettajaksi" ja "kaikin puolin kunnioitettavaksi tohtoriksi”. Ks. Wuolijoki 1954, s.63-64.

100 KA, EGK, kansio 3; vrt. Yrjö-Koskinen, Yrjö Sakari, Johtavat aatteet ihmiskunnan historiassa. III painos. Helsinki 1960 (1900), s.57-58. Alkuperäinen teos ilmestyi vuonna 1879 ja toinen, korjattu painos, vuonna 1900. Kolmas painos perustuu toiseen, missä oli joitain muodollisia korjauksia, mutta sisältö oli sama kuin alkuperäisessä teoksessa.

101 KA, EGK, kansio 3.

102 Yrjö-Koskinen, Yrjö-Sakari, Suomen kansan historia. 3.painos. Historiallinen Kirjasto II. Helsinki 1933 (1881), s.586-637.

103 Tästä tarkemmin Tommila, Päiviö. Suuri Adressi. Helsinki 1999. 
tilanteeseen. Gylling kirjoitti sen loppuvuodesta 1899 tai alkuvuodesta 1900 helmikuun manifestin jälkeisissä tunnelmissa. Hänen mukaansa Englannin siirtomaissa tapasi "vapaiden olojen kasvattaman onnellisen kansan", jolla oli täydellinen autonomia, oma parlamentti, sotajoukko, koululaitos ja tullijärjestelmä. Englannin "inhimillinen" politiikka johti siihen, että siirtomaat tunsivat solidaarisuutta emämaansa kanssa. Autonomia oli siis edullista molemmille osapuolille, missä tulkinnassa voi nähdä kaikuja Suomen tilanteesta venäläistämispolitiikan alla. ${ }^{104}$

Gylling korosti aineissaan historian keskeisinä tekijöinä lähinnä aatteita, moraalia ja merkittäviä yksilöitä. Nämä tekijät olivat vallitsevassa historiankäsityksessä vahvasti esillä. Esimerkiksi Yrjö Koskinen korosti maailmanhistorian keskeisinä tekijöinä aatteita, joista tärkeimpiä olivat yleinen humanismi, rauhanaate ja kansallisuusaate. Erityisesti ensimmäiseen liittyi moraalinen edistys kohti yhä suurempaa inhimillisyyttä. Koskisen historiankuvassa merkittävät yksilöt kuten Kaarle Suuri ja Martin Luther olivat keskeisellä sijalla. ${ }^{105}$

Kaiken kaikkiaan Gylling kirjoitti useita historiallisia aineita, arkipäivän kuvauksia ja runollisia luontokuvauksia, joissa hän muun muassa vastusti eläinrääkkäystä ja kuvaili torppareiden elämää varsin positiiviseen sävyyn. Hänen aineistaan saamat arvosanat vaihtelivat välillä 7-10 ja kohosivat tasaisesti lyseon edetessä. ${ }^{106}$ Gyllingin ylioppilasaineet eivät ole säilyneet. Niiden aiheet olivat Kansojen taistelu Napoleonia vastaan ja Ensimmäinen triumviraatti. ${ }^{107}$

Gylling edusti ajalleen tyypillistä sivistynyttä nuorukaista, joskin keskimääräistä lahjakkaampaa ja ahkerampaa. Hänen aineissaan näkyvät selvästi aikakaudelle keskeiset kansalliset arvot ja orastava sosiaalinen ajattelu. Gylling oli kiinnostunut historiasta,

104 KA, EGK, kansio 3.

105 Vrt. esim. Yrjö-Koskinen 1960 (1900), s.153, 268, 318-328.

106 KA, EGK, kansio 3.

107 KansA, KGS, kansio 1, Pentti Papusen luentomuistiinpanot aiheesta: Gyllingin Kalmaan kokoelma. 
joskaan mitään kovin omaperäistä sanottavaa hänellä ei siitä vielä voinut olla.

\section{Historiallisen kansantaloustieteen merkitys}

Gylling aloitti yliopisto-opinnot Helsingin yliopistossa vuoden 1900 syksyllä pääaineenaan maanviljelyksen kansantalous- ja tilastotiede. Lisäksi hän opiskeli Suomen, pohjoismaiden ja Venäjän historiaa, Rooman kirjallisuutta, filosofiaa ja maantiedettä. Vuonna 1902 hän suoritti myös kirjanpitokurssin. ${ }^{108}$ 1900-luvun alussa ei ollut keskisuomalaista osakuntaa, joten Jyväskylän lyseon ylioppilaat valitsivat yleensä hämäläisen osakunnan. Gylling liittyi kuitenkin Savo-Karjalaiseen osakuntaan mutta ei toiminut siinä aktiivisesti. ${ }^{109}$ Valmistumisensa jälkeen hän piti kuitenkin osakunnan vuosijuhlassa 1905 esitelmän kapitalismin historiallisesta kehityksestä. ${ }^{110}$

Gyllingin tärkeimpiä akateemisia opettajia olivat historioitsijat E. G. Palmén (1849-1919), J. R. Danielson-Kalmari ja K. R. Melander (1858-1941) sekä tilasto- ja väestötieteilijä J. V. Tallqvist (1862-1960). ${ }^{111}$ Palmén oli lähinnä taloushistorian ja poliittisen historian tutkija kun taas Melander kuului 1600-luvun yhteiskunnasta kiinnostuneeseen kameraalihistorialliseen koulukuntaan. ${ }^{112}$ Tallqvist oli kiinnostunut kansantaloustieteen ja sosiaalipolitiikan ongelmista. ${ }^{113}$ Danielson-Kalmari oli tehnyt jo vuonna 1880 pro-

\section{KA, EGK, kansio 1.}

109 Helsingin Yliopiston Kirjasto (HYK), Savo-Karjalaisen osakunnan pöytäkirjat (ptk.) 1900-1904. Gylllinin voi sanoa olleen varmasti läsnä ennen vuoden 1905 vuosijuhlaa ainoastaan 19.10.1903, jolloin keskusteltiin ns. talkkunajuhlien järjestämisestä.

110 Autio,Veli-Matti, Roudan aika. Savo-Karjalaisen osakunnan historia III, 1888-1905. Porvoo 1997, s.229. Juhlaesitelmän pitäjäksi pyrki myös jyrkkä vanhasuomalainen Leo Schadewitz, joka kuitenkin hävisi kilvan Gyllingille.

111 Heikkinen - Mauranen 1985, s.90.

112 Tommila 1989, s.138, 142.

113 Alapuro - Alestalo 1992, s.108. 
fessorinväitöksensä Englannin sosiaalipolitiikasta ja taloudellisesta kehityksestä. Vuosisadan vaihteessa hän alkoi painottaa taloudellisia ja sosiaalisia ilmiöitä entistä voimakkaammin. ${ }^{114}$

Suurin vaikutus Gyllingin ajatteluun oli kuitenkin maanviljelysja kansantaloustieteen dosentti Hannes Gebhardilla (1864-1933), joka oli aineen ainoa opettaja. Hänen oppilaikseen voidaan laskea Gyllingin lisäksi myös Sulo Wuolijoki, Martti Kovero ja O. K. Kilpi (1878-1937). Gebhard keskittyi tutkimus- ja opetustyössään taloudellisiin ja sosiaalipoliittisiin tekijöihin. Gebhard ei ehtinyt opettamaan kovin paljoa, mutta hänen panoksensa tutkimusvirikkeiden ja aatteellisten herätteiden antajana sekä töiden ohjaajana oli merkittävä. ${ }^{115}$

Gebhard pyrki yhdistämään maaseudun väestön olojen tutkimuksen niiden poliittiseen uudistamiseen. Hän oli suomalaisen osuustoimintaliikkeen pioneeri, joka perustamansa Pellervoseuran kautta edisti vahvasti maaseudun osuustoimintaa ja valistustyötä. Gebhardin suurta merkitystä kuvastaa se, että häntä on kutsuttu "Suomen osuustoiminnan isäksi". Hän oli myös keskeinen hahmo tilattoman väestön oloja kartoittaneen Tilattoman väestön alakomiteassa, joka julkaisi vuosina 1908-1018 erittäin laajan, kuusiosaisen tutkimuksen Tilastollinen tutkimus yhteiskuntataloudellisista oloista Suomen maalaiskunnissa v.1901. Gebhardin tärkein tavoite oli itsenäisen ja taloudellisesti vauraan maatalousväestön luominen maanomistussuhteita muuttamalla. Vuonna 1909 hänet nimitettiin maanviljelyksen kansantalouden ja tilastotieteen ylimääräiseksi professoriksi. ${ }^{116}$

114 Tervonen 1991, s.171.

115 Alanen, Aulis J., Hannes Gebhard, Helsinki 1964, s.74-76; Gebhardin historiannäkemyksenä oli aluksi hegeliläis-snellmanilainen kansallisuutta korostava idealismi, mutta vähitellen taloudelliset ja sosiaalipoliittiset tekijät yhä suuremman merkityksen hänen ajattelussaan. Tästä tarkemmin Tervonen, Jukka, Historioitsijasta kansantaloustieteilijäksi. Teoksessa Patriotismi, historia ja sosiaalireformismi. Historiallisen laitoksen julkaisuja N:o 2. Toim. Pulkkinen, Tuija. Helsinki 1985, s.84-85.

116 Alapuro - Alestalo 1992, s.86-88; Hilson, Mary, Transnational networks in the development of the co-operative movement in the early twentieth century: Finland in the northern context. Teoksessa Hilson, Mary - Mark- 
Gebhard oli porvarillinen sosiaalireformisti, joka halusi iskostaa oppilaisiinsa maareformin tärkeyden. Tämä onnistuikin hyvin, sillä sekä Gylling että Kovero väittelivät maatalouteen liittyvistä asioista ja Wuolijokikin teki siitä muuta tutkimusta. Gylling ja Wuolijoki nousivat myöhemmin myös sosialidemokraattien johtaviksi maatalousasiantuntijoiksi, mutta Kovero ei toiminut politiikassa. ${ }^{117}$

Gebhardin ajattelu nojautui pitkälti kansantaloustieteen historialliseen koulukuntaan, joka arvosteli klassista taloustiedettä historiallisen näkökulman väheksymisestä. Sen edustajien mukaan kunkin maan taloutta pitäisi tarkastella sen omien instituutioiden, sosiaalisten käyttäytymismallien ja kulttuuristen asenteiden muodostamaa taustaa vasten. Tästä näkökulmasta katsoen taloustiede oli korostetusti empiirinen ja induktiivinen tiede. ${ }^{118}$ Historiallinen koulukunta hallitsi 1800-luvun Saksan taloustieteellistä keskustelua lähes yksinvaltiaan tavoin. Sieltä se levisi vaihtelevalla menestyksellä muuallekin, myös Suomeen. ${ }^{119}$

kola, Pirjo - Östman, Ann-Catrin, Co-operatives and the Social Question. The co-operative movement in northern and eastern Europe (1880-1950). Scandinavia and the Baltic transnational and international challenges. Ed. Lavery, Jason. Cardiff 2012, s.88-90.

117 Sulo Wuolijoki kirjoittaa tästä värikkäästi muistelmissaan. Wuolijoki 1954, s.65. Koveron väitöskirja ei tosin liittynyt varsinaisesti maanvuokraajakysymykseen, vaan se käsittelee valtion uudisasutusta isonvihan jälkeisillä Suomen alueilla. ks. Kovero, Martti, Valtion uutisasutus Ruotsin-Suomessa jälkeen Ison-vihan. Asutuspoliittinen tutkimus. Helsinki 1909.

118 Pekkarinen, Jukka, Kansantaloudellinen Yhdistys ja taloudellinen keskustelu Suomessa. Teoksessa Sata vuotta suomalaista kansantaloustiedettä. Kansantaloudellinen Yhdistys 1884-1984. Toim. Koskenkylä, Heikki et al., Vammala 1984, s.16-17; Alapuro - Alestalo 1992, s.78-80; Tosin koko käsite "kansantaloustieteen historiallinen koulukunta" on ongelmallinen, koska siihen sisältyy varsin monenlaisia ja ristiriitaisia aineksia. Tästä tarkemmin Grimmer-Solem, Erik - Romani, Roberto, The historical school 1870-1900: a crossnational reassessment. History of Euroapean ideas, Vol 24, Numbers 4-5/1988, s.267-299.

119 Eräsaari, Risto, Saksan historiallinen koulukunta. Teoksessa Talous ja yhteiskuntateoria 1. Vanhan maailman talous ja suuri murros. Toim. Heiskala, Risto - Virtanen, Akseli. Helsinki 2011, s. 266-270, 288-290. 
Saksassa kansantaloustieteen historiallisen koulukunnan nuorempi siipi perusti Gustav Schmollerin (1858-1917) johdolla Verein für Sozialpolitik -yhdistyksen ajamaan sosiaalisia reformeja marxilaisen sosialismin kärjen taittamiseksi ja Saksan yhtenäisyyden lisäämiseksi. Yhdistys korosti historiallisen taustan merkitystä taloudellisen kehityksen ymmärtämisessä ja pyrki yhdistämään tutkimuksen yhteiskunnallisiin reformeihin. Sen jäsenet harjoittivat konkreettista tutkimusta, jolle oli tyypillistä käytännöllisiin yhteiskunnallisiin ongelmiin läheisesti liittyvä sosiaalitilastollinen ja sosiaalipoliittinen tutkimus. ${ }^{120}$ Yhdistyksen linjassa yhdistyivät historiallinen tarkastelutapa, klassisen taloustieteen arvostelu, kiinnostus tilastoihin ja pyrkimys sosiaalisiin reformeihin lainsäädännön kautta. ${ }^{121}$

Vuonna 1884 suomenkieliset yliopisto- ja virkamiehet perustivat saksalaista esimerkkiä seuraten Kansantaloudellisen Yhdistyksen, jonka julkaisusarjoissa ilmestyi monia merkittäviä tutkimuksia. Lisäksi yhdistys julkaisi Yhteiskuntataloudellista Aikakauslehteä ja harjoitti vilkasta käännöstoimintaa. Sosiaalireformistinen taustaviritys ja mielenkiinto sosiaalipoliittisiin kysymyksiin tekivät yhdistyksestä eräänlaisen yhteiskunnallisen

120 Alapuro ja Alestalo katsovat, että konkreettisen sosiaalitutkimuksen historia voidaan ulottaa aina 1600 -luvulle saakka, joskin vasta teollistumisen yhteydessä siitä tuli merkittävä suuntaus. Alapuro - Alestalo 1992, s.7778; Konkreettinen sosiaalitutkimus on tosin saanut monenlaisia muotoja historiansa aikana. Risto Eräsaari katsoo sen tunnusmerkiksi käytännönläheisyyden ja luokittelee sen kolmeen suuntaukseen: 1. manipulatiivinen, tekninen ja valtiollinen suuntaus, 2. reformiskriittinen tutkimus ja 3. kriittis-vallankumouksellinen tutkimus. Eräsaari, Risto, Konkreettisen sosiaalitutkimuksen syntymekanismit. Teoksessa Edvard Gylling - työväenliikkeen tiedemies. Helsinki 1983, s.24-27.

121 Vereinin erittäin arvovaltaisessa tutkimussarjassa toimitettiin vuosien 1873 ja 1932 välisenä aikana lähes 200 laajaa sosiaalihistoriallista ja -tilastollista sekä talouspoliittista nidettä. Yhdistyksellä ei kuitenkaan enää 1920- ja 1930-luvuilla ollut merkittävää asemaa saksalaisessa yhteiskuntatieteessä, ja sen toiminta lakkasi vuonna 1936. Tarkemmin tästä Eräsaari - Rahkonen, 1975 s.26, 38-40; vrt. myös Eräsaari 2011, s.279-281. 
painostusryhmän. ${ }^{122}$ Monet Kansantaloudellisen Yhdistyksen jäsenistä toimivat Suomalaisessa Puolueessa. Gylling liittyi vuonna 1903 yhdistykseen ja oli sen vanhasuomalaisesta leimasta huolimatta jäsenenä sisällissotaan asti. Hän piti yhdistyksen kokouksissa neljä esitelmää: vuonna 1904 maalaistyöväestön oloista Ikaalisten pitäjässä, vuonna 1910 Suomen väkiluvun kehityksestä vuodesta 1749 lähtien, vuonna 1911 Katsaus Suomen ruotsalaisen väestön kehitykseen vuosina 1749-1908 ja vuonna 1914 Tärkeimpien viljelyskasvien viljelyksen kehitys Suomessa 1800-luvun alusta alkaen. ${ }^{123}$

Gebhard oli opiskellut Berliinissä Schmollerin johdolla ja tutkinut siellä eri maiden maataloustilastoja. ${ }^{124}$ Gebhard omaksui tuolloin kansantaloustieteen historiallisen koulukunnan tutkimukselliset metodit ja sosiaalireformistiset pyrkimykset. ${ }^{125}$ Gyllingin opettajista myös Danielson-Kalmari oli saanut paljon taloustieteellisiä ja sosiaalipoliittisia vaikutteita Schmollerin ajattelusta. He olivat mukana Kansantaloudellisen Yhdistyksen toiminnassa, kuten myös Palmén ja Tallgvist. ${ }^{126}$

Gylling sai siis jo opiskeluaikanaan vahvoja välillisiä vaikutteita kansantaloustieteen historiallisen koulukunnan ajattelusta. Tätä kautta hän sai taustatietoa ja - näkemyksiä oman aikansa

122 Pekkarinen 1984, s.23; Tervonen 1991, s.161; Alapuro - Alestalo 1992, s.81-83.

123 Kansantaloudellisen Yhdistyksen jäsenluettelo, vuosi 1903 ja esitelmäluettelo vuosilta 1904-1914. Molemmat painettuna teoksessa Harmaja Leo, Kansantaloudellinen Yhdistys 1884-1934. Helsinki 1934, s.160-163, 180.

124 Allardt 1997, s.65-66.

125 Tämä näkyy siinä, miten Gebhard määrittelee oppiaineensa, maatalousopin ja maanviljelyksen kansantaloustieteen: "...se osa yleistä kansantaloustiedettä, jonka tehtävänä on tieteellinen selonteko siitä, miten jonkun maan maanviljelys- ja maalaisolot ovat kehittyneet sellaiseksi kuin ne ovat, sekä mihin suuntaan on pyrittävä sellaisen maalaisväestön taloudellisen ja yhteiskunnallisen aseman saavuttamiseksi, joka sille itselle, valtiolle ja yhteiskunnalle on tarkoituksenmukaista." Gebhard, Hannes, Maatalousoppi ja maanviljelyksen kansantaloustiede tutkimus- ja opetusaineina. Valvoja 1901, s.327.

126 Harmaja 1934, s.21-22; Tervonen 1991, s.157-161. 
maatalouteen liittyvien kysymysten tutkimiseen, mikä puolestaan linkittyi tiiviisti erilaisten sosiaalisten ongelmien ratkaisemiseen. Historiallinen näkökulma olikin hänen maatalouspoliittisessa ajattelussaan keskeinen, vaikka myöhemmin se sai yhä selvemmin marxilaisia sävyjä. Gylling aloitti tieteellinen toimintansa aikana, jolloin ero yhteiskuntatieteiden ja historian välillä oli syntynyt mutta läheinen suhde oli edelleen olemassa. Hän kuului ensimmäiseen suomalaiseen tutkijasukupolveen, johon soveltui määre yhteiskuntatieteilijä. ${ }^{127}$

Gylling suoritti toukokuussa 1903 filosofian kandidaatin tutkinnon historialliskielitieteelliseen osastoon. Hän suoritti laudaturkokonaisuuden pääaineestaan maanviljelyksen kansantalous- ja tilastotieteestä sekä Suomen, Venäjän ja Pohjoismaiden historiasta. Tutkintoon sisältyi lisäksi lubenter approbatur -kokonaisuus filosofiasta sekä approbaturit Rooman kirjallisuudesta ja maantieteestä. Suomenkielisestä kirjoitusnäytteestä Gylling sai arvosanan cum laude approbatur. Hän sai tutkintoonsa 11 puoltoääntä maksimin ollessa 18. ${ }^{128}$ Gylling teki sivulaudaturtyön Pohjoismaiden historiasta aiheenaan Viron tanskalaisvallan perustamisen vaiheet vuoteen 1222. Laudaturtyön pituus oli 86 käsinkirjoitettua sivua ja sen päälähteenä oli Henrik Lättiläisen kronikka. ${ }^{129}$

127 Heikkinen, Sakari - Mauranen, Tapani, Edvard Gylling, yhteiskuntatiede ja historia. Teoksessa Patriotismi, historia ja sosiaalireformismi. Helsingin yliopiston historian laitoksen julkaisuja 2. Toim. Pulkkinen, Tuija. Helsinki 1985, s.89; Muita 1900-luvun alun tutkijoita, jotka liikkuivat sekä yhteiskuntatieteiden että historian alueilla olivat mm. V. Voionmaa, H. Renvall, E. Hynninen, O. K. Kilpi, T. Kallio, E. Kuusi, E. Nevanlinna, K. R. Brotherus, A. Hjelt ja A. Waren. Useimmille heistä oli tieteellisen moninaisuuden - tai eriytymättömyyden - lisäksi ominaista aktiivinen yhteiskunnallinen osallistuminen. Haapala, Pertti, Muotia vai ei? Suomalaisen sosiaalihistorian muuttuvat näkökulmat. Teoksessa Yksilö ja yhteiskunnan muutos. Viljo Rasilan 60-vuotis juhlakirja. Toim. Kiuasmaa, Kyösti et al., Acta Universitatis Tampereansis, ser A, vol 202. Tampere 1986, s.265.

128 KA, EGK, kansio 1.

129 KA, EGK, kansio 3, Edvard Gyllingin sivulaudaturtyö. Työ oli varsin tyypillistä sotahistoriaa ja poliittista historiaa, missä käsiteltiin muun muassa kirkon käännytystyötä ja valloitussotia. Kaiken kaikkiaan työssä oli melko yksityiskohtainen katsaus poliittisten suhteiden kehittymiseen tanskalais- 


\section{Tutkielma maatyöväestön oloista}

Suomen maaseutu oli ollut vielä 1500- ja 1600-luvuilla yhtenäisen talonpoikainen. Maatalousväestö alkoi kuitenkin eriytyä, kun 1700-luvun puolivälin jälkeen torppareiden ja 1800-luvulla varsinaisen tilattoman väestön määrä kasvoi nopeasti. Torpparikysymys kohosi 1800- ja 1900-luvun vaihteessa keskeiseksi maatalouspoliittiseksi ongelmaksi, vaikka torpparit olivat vähemmistö tilattoman maalaisväestön keskuudessa ja he tulivat paremmin toimeen kuin varsinainen tilaton väestö. Tämä ero oli kuitenkin supistumassa, kun torpparien taloudellinen tilanne heikkeni suhteellisesti 1900 -luvun alussa. ${ }^{130}$

Maaseudun ongelmat kärjistyivät 1800-luvun lopun Suomessa. Erityisesti vuosi 1899 on maaseudun alempien kerrosten radikalisoitumisen kannalta keskeinen vuosi. Tuolloin maaseudulla esiintyi laajaa liikehdintää, jonka taustalla on nähty venäläisten levittämät maanjakohuhut, joihin maaseudun köyhälistö kritiikittömästi uskoi. Matti Peltonen korostaa kuitenkin maalaisköyhälistön vaatimusten laajuutta, omaa aktiivisuutta ja illuusiottomuutta monarkismin suhteen. Suomalaisen sivistyneistön valtaosa ei kuitenkaan ymmärtänyt tilannetta ja pyrki palauttamaan kuvittelemansa yhteisyyden maaseudulle. ${ }^{131}$

Gyllingin pro gradu -tutkielma Maanviljelystyöväen taloudellisista oloista Ikaalisen pitäjässä vuonna 1902 valmistui vuonna 1903. Sen aihe oli uraauurtava, koska maatyöväen elinoloista Suomessa ei ollut aikaisemmin tehty tieteellistä tutkimusta. Venäjän keisarivallan toimesta oli tosin vuonna 1901 perustettu Tilatto-

ten, saksalaisten ja katolisen kirkon välillä. Gyllingin mukaan vuonna 1222 allekirjoitettu Saarenmaan sopimus oli kehityksen loppu- ja huippukohta, koska tällöin Tanskan kuninkaan Valdemarin valta Virossa oli ehdoton ja osa laajaa suunnitelmaa Itämeren ylivallan saavuttamiseksi oli toteutunut.

130 Soininen, Arvo M., Maa- ja metsätalous. Suomen taloushistoria 2, Teollistuva Suomi. Helsinki 1982, s.32-34; Kerkelä, Heikki, Vanhan maailman peilissä. Modernin yhteiskunnan synty ja pohjoinen aineisto. Tampere 1996, s.210-213, 218-220; Peltonen 2004, s.251-252.

131 Peltonen 1992, s.257-264. 
man väestön alakomitea selvittämään maanhankintavarojen järkevää käyttöä. Sen selvitystyön tuloksena saatiin aikaan laaja maaseudun yhteiskunnallisia oloja käsittelevä tilasto, joka kuitenkin julkaistiin vaiheittain vasta vuosina 1908-1918. Näin ollen sillä ei ollut juuri merkitystä torpparikysymyksen kannalta, varsinkin kun sen antama kuva maaseudun eri väestöryhmistä ei ollut kovin tarkka. ${ }^{132}$ Tilattoman väestön alakomitean sihteerinä ja keskeisenä toimijana oli Hannes Gebhard, joka epäilemättä tuki Gyllingiä pro gradu -tutkielman aiheen valinnassa.

Gylling valitsi tutkimuspaikaksi Ikaalisen ilmeisesti sen takia, että hän saattoi asua siellä sijaitsevalla sukutilalla. Pro gradu julkaistiin vuonna 1907 Kansantaloudellisen Yhdistyksen julkaisusarjassa Taloustieteellisiä tutkimuksia. Se käsitti 179 sivua ja pohjautui monipuoliseen ja perusteelliseen tilastolliseen analyysiin. Gylling totesi esipuheessa täydentäneensä alkuvuodesta 1905 alkuperäistä tutkielmaansa jonkin verran. Julkaistu tutkielma on tämä täydennetty versio. ${ }^{133}$ Seuraavaksi analysoidaan julkaistua versiota, jonka lopun täydennykset tuovat kiinnostavan lisän Gyllingin ajatteluun. Alkuperäinen, painamaton versio, ei ilmeisesti ole säilynyt.

Gyllingin tutkimustehtävänä oli Ikaalisen maatyömiesluokan taloudellisten olojen selvittäminen, joka pohjustetaan läpileikkauksella taloudellisesta rakenteesta. Hän määritteli maatyömieheksi henkilön, jonka toimeentulon pääosa muodostui maatöistä. Gyllingin mukaan tämän heterogeenisen joukon tarkempi määrittely oli ongelmallista, mutta hän päätyi laskemaan maatyömiesluokkaan kuuluvaksi ruokakunnat, joilla oli viljeltävää maata alle kolme hehtaaria. Tämä joukko jakautui palkollisiin, muonarenkeihin ja vapaisiin työmiehiin, joista osa viljeli maata. Ikaalisissa oli yhteensä 986 maatyömiestä, jotka perheineen käsittivät 2883 henkilöä, mikä oli noin 26,7 \% pitäjän väestöstä. Valtaosa maatyömiehistä harjoitti maanviljelystä yksityisiltä vuokratulla maalla.

132 Rasila 1961, s.215-218.

133 Gylling, Edvard, Maanviljelystyöväen taloudellisista oloista Ikaalisten pitäjässä v.1902. Taloustieteellisiä tutkimuksia III. Helsinki 1907 (A), esipuhe. 
Gyllingin tutkimus koski siis myös torppareita. ${ }^{134}$ Tällaiset määritelmät eivät ole yksiselitteisiä, mutta Gyllingin lähtökohta vastaa varsin hyvin nykytutkimuksen kokonaiskuvaa. ${ }^{135}$

Gylling lähti liikkeelle tapansa mukaan historiallisella katsauksella, vaikka valittikin sen jääneen liian pintapuoliseksi olojen syvälliselle ymmärtämiselle. Ikaalisten tilattomien määrä kasvoi vuodesta 1880 alkaen selvästi, mikä synnytti työvoiman ylitarjontaa, jolloin työttömyys kasvoi. Tämän taustana olivat suurviljelyksen edistyminen, viljelysten periminen jakamattomana ja teollisuuden puuttuminen alueelta. Lähinnä tilattomien piiristä lähteneiden siirtolaisten määrä kasvoi 1900-luvun alussa. Suurviljelykset käyttivät pienempiä enemmän vakituisessa työsuhteessa olevia työmiehiä. ${ }^{136}$

Gylling kiinnitti huomiota myös maatyöväen perheiden sisäiseen työnjakoon. Ikaalisten maatyömiehistä suurin osa työskenteli pienillä ja keskikokoisilla tiloilla, joilla oli paljon tilapäisiä töitä, varsinkin kesällä. Tällaisia tilapäisiä töitä olivat esimerkiksi kalastus, puutavaroiden valmistus ja metsätyöt. Koska näitä ei ollut riittävästi, niin sesonkiluontoinen työttömyys oli myös varsin suurta. Gyllingin mukaan naisille kuuluivat "luonnollisesti" sisätyöt, karjan hoito ja kesällä osin myös ulkotyöt. Hän kiinnitti lisäksi kriittistä huomiota lasten ulkotöihin, jotka keveydestään huolimatta rasittivat heitä kovasti. ${ }^{137}$

134 Gylling 1907 A, s.1-25; vrt. Gebhard, Hannes, Maanviljelysväestö. Sen suhde muihin elinkeinoryhmiin ja sen yhteiskunnallinen kokoonpano Suomen maalaiskunnissa. Tilattoman väestön alakomitean tilastollinen tutkimus yhteiskuntataloudellisista oloista Suomen maalaiskunnissa 1901. Helsinki 1913, s.12.

135 Vrt. esim. Östman 2004, s.56 ja Vihola, Teppo, Pärjääkö pienviljelys? Teoksessa Suomen maatalouden historia 2. Kasvun ja kriisien aika 1870-luvulta 1950-luvulle. Toim. Peltonen, Matti. Helsinki 2004, s.154-155.

136 Gylling 1907 A, s.1,25-31.Erik Allardtin mukaan Gylling osoittaa tässä tutkimuksessaan selvästi sen, kuinka uusi luokka syntyy. Allardt 1997, s.73.

137 Gylling 1907 A, s.55-65; 1900-luvun alun työväenliikkeen käsityksistä naisten asemasta ks. Markkola, Pirjo, Työläiskodin synty. Tamperelaiset työläisperheet ja yhteiskunnallinen kysymys. 1870-luvulta 1910-luvulle. Historiallisia tutkimuksia 187. Helsinki 1994, s.32-38; Naisten asemasta erityisesti 
Gyllingin tutkimuksen mukaan maatyömiehen työaika vaihteli vuodenajan mukaan kuudesta tunnista 16,5 tuntiin päivässä. Työajasta riippuva palkka maksettiin rahana, luonnontuotteina tai näiden yhdistelmänä. Gyllingin mukaan palkollisten olot vaihtelivat varsin paljon tiloittain. Yleisesti ottaen pienillä ja keskisuurilla tiloilla palkollisten ja isäntäväen suhde oli parempi kuin suurtiloilla. Hänen mukaansa voimassa oleva palkollissääntö olikin pientiloilla tarpeeton ja suurtiloilla usein "kahle, joilla palkollisluokkia pidetään kurissa" - erityisesti niillä paikkakunnilla, missä se alkaa herätä. Hän yhtyi SDP:n vaatimukseen palkollissäännön poistamisesta. ${ }^{138}$ Tämä kannanotto on ilman muuta lisätty tutkielman painettuun versioon. Gylling nimittäin valmistui filosofian kandidaatiksi toukokuussa 1903, kun taas Suomen Työväenpuolueen nimi muutettiin Suomen Sosialidemokraattiseksi Puolueeksi elokuussa 1903. Gylling ei siis voinut pro gradua tehdessään puhua Sosialidemokraattisen Puolueen ohjelmasta.

Gylling kiinnitti erityistä huomioita muonarenkien asemaan ja kuvasi sen synkäksi. Hänen mukaansa muonarengeillä ei juuri ollut sosiaalisen nousun mahdollisuutta, vaan he jäivät yleensä lopun iäkseen asemaansa. Gylling määritteli muonarengit työväen-luokkaan sanan ahtaammassa merkityksessä. Maatyömiesten selvä enemmistö oli kuitenkin yksityisen mailla olevia torppareita, jotka voitiin erotella pien- ja suurtorppareiksi. Torpan tarjoamat edut viljelijälleen olivat moninaiset ja hallintaoikeus pitkäaikainen. Varsinkin suurempien torppien vuokraoikeus ja hallintaoikeus olivat Ikaalisissa varsin laajat. Gyllingin mielestä maanvuokralaissa oli toisaalta monia kiertoteitä, joiden avulla sopimusehtoja voitiin polkea. Ikaalisten tyyppinen pienten ja keskikokoisten tilojen hallitseva asema oli kuitenkin torpparien kannalta edullisin tilanne, eivätkä epäkohdat olleet räikeitä. ${ }^{139}$

maanvuokraajien perheissä myös Markkola, Pirjo - Östman, Ann-Catrin. Torparfrågan tillspetsas. Frigörelse, oberoende och arbete 1919 års torparlagstifning ur mansperspektiv. Historisk tidskrift för Finland 1/2012, s, 20-23,40-41.

138 Gylling 1907 A, s.64-103.

139 Gylling 1907A, s.105-145. 
Gylling kirjoittikin vuonna 1907, että Ylä-Satakunnan torppariolot voisivat monessa suhteessa olla mallina yleisemmälle maanvuokraajaratkaisulle. Hänen mukaansa torppareilla oli siellä parempi asema kuin muualla ainakin oikeudellisesti, vaikkakaan ei ehkä taloudellisesti. Taustalla olivat historialliset syyt: talolliset olivat Ylä-Satakunnassa yleensä vähävaraisia, joten maanvuokrausjärjestelmästä oli heille selkeää hyötyä. ${ }^{140}$

Gylling totesi painetun version loppukatsauksessa, että hänen aikanaan tekemänsä jako maatyöväen ja muun maaseudun työväestön välillä oli keinotekoinen. ${ }^{141}$ Koska maatyömiehet tekivät sivutöinään metsä- ja tukkitöitä ja muusta työstä elävät olivat varsinkin kesällä maatöissä, näiden kahden ryhmän raja oli häilyvä. Keskeistä oli, että molemmat ryhmät olivat riippuvaisia samoista taloudellisista tekijöistä. Voimistunut kapitalistinen kehitys kasvatti maaseudun työväenluokkaa ja aiheutti työvoiman liikatarjontaa, mikä johti palkkojen laskuun ja kasvavaan siirtolaisuuteen. Siirtolaisuus esti tämän laajan väestökerroksen rappeutumisen. Maatyöväen suurin ryhmä olivat torpparit, joiden asema oli alueella tavallista itsenäisempi. Palkolliset olivat yleensä vain lyhyen ajan työmiehinä ja pyrkivät yleensä torppareiksi. Huonoin asema oli muonarengeillä. ${ }^{142}$

Gylling siis katsoi, että siirtolaisuus toimi eräänlaisena sosiaalisten ongelmien välttämättömänä varaventtiilinä. Sitä parempi ratkaisu olisi kuitenkin ratkaista alueen yhteiskunnalliset epäkohdat. Hän esitti viisi keinoa Ikaalisten tilattaman väestön ja maatyömiesten aseman parantamiseksi: 1. uudisasutuksen voimakas jatkaminen valtion mailla, 2. torppariolojen kaikenpuolinen uudistus, jotta uudisasutus yksityisten mailla voisi nopeutua, 3. pienviljelyksen tuottavuuden kasvattaminen, 4. teollisuuden edistämi-

140 Gylling, Edvard, Ylä-Satakunnan torpparioloista. Satakunta I, kotiseutututkimuksia. 1907 (D), s.235-239.

141 31.1.1907 kirjoitetussa esipuheessa Gylling totesikin erotelleensa nämä ryhmät liian jyrkästi. Ne olisi voinut yhdistää, kuten loppukatsauksessa tehdäänkin. Gylling 1907 A, esipuhe.

142 Gylling 1907 A, s.165-17; vrt. Allardt 1997, s.73. 
nen paikkakunnalla ja 5. maatyöväenliikkeen edistäminen. ${ }^{143} \mathrm{On}$ todennäköistä, että Gylling lisäsi nämä kohdat vuoden 1905 alussa muokatessaan pro gradu -tutkielmaansa julkaistavaksi. Ainakin kohdat kaksi ja viisi ovat selkeästi sosialidemokraattisia ajatuksia. Ei ole uskottavaa, että Gylling olisi jo opinnäytetyötä tehdessään päätynyt kannattamaan näitä toimenpiteitä.

Joka tapauksessa Gylling tutustui lopputyötään tehdessään ensimmäistä kertaa toden teolla maaseudun sosiaaliseen tilanteeseen. Ikaalisissa epäkohdat olivat pienempiä kuin maassa keskimäärin, mutta viimeistään tämän tutkielman aikana hän toden teolla kiinnitti huomionsa maaseudun yhteiskunnallisiin ongelmiin.

Gylling oli vakaasti päättänyt hankkia tohtorinarvon. Hän suunnitteli tutkivansa maatalousolojen historiallista kehitystä Pohjois-Euroopan eri maissa. Tavoitteena oli vertaileva tutkimus ilmaston merkityksestä tälle kehitykselle. ${ }^{144}$ Gylling huomioi jo pro gradu-tutkielmassaan lyhyesti Ikaalisen ilmaston maatalousolojen kehityksen taustana. ${ }^{145}$

Nykyaikanakin ajankohtaisella ilmalähtöisellä yhteiskuntatutkimuksella on pitkä perinne. Ranskalainen valistusfilosofi Montesquieu (1689-1755) korosti fysikaalisten ja maantieteellisten tekijöiden eli ilmaston merkitystä kulttuurin kehitykselle. Hänen perintöään jatkoi ranskalainen historioitsija Jean Michelet (17981874). Suomessa varsinkin Zacharias Topelius tulkitsi 1800-luvulla johdonmukaisesti historian tapahtumia luonnonolosuhteiden pohjalta. 1900-luvun alussa maantiedon ja historian yhteyttä toi esiin lähinnä Väinö Voionmaa. ${ }^{146}$

143 Gylling 1907 A, s.170-171.

144 KA, EGK, kansio 5, Edvard Gyllingin kirjeet Fanny Achrénille 13.4.1904 ja 26.5.1904.

145 Gylling 1907 A, s.31-33.

146 Suutala, Maria, Luonto ja kansallinen itsetarkoitus. Teoksessa Hyöty, sivistys, kansakunta. Toim. Manninen, Juha - Pataluoto, Ilkka. Oulu 1986, s.237; Tommila 1989, s.151-152; Klinge 1998, s.272-273. 


\section{Laajan tilastollisen selvityksen johtajana}

1900-luvun alussa tieteellistä uraa suunnitteleva maisteri jatkoi yleensä opintojaan Saksassa, jonne myös Gylling suuntasi. Hän opiskeli vuoden 1904 helmikuusta heinäkuuhun muun muassa Gustav Schmollerin luennoimaa historiallista kansantaloustiedettä ja työväen olojen tutkimista sekä maatalouden taloustieteen auktoriteetin Max Seringin (1857-1938) luennoimaa finanssioppia. ${ }^{147}$ Gylling omaksui Schmollerin luennoilla ja seminaareissa monia tieteellisiä käsityksiä, jotka yleisemminkin olivat voittaneet lisää alaa. Gyllingin mielestä Schmoller oli kansantaloustieteen uranuurtaja, jonka käsityksiä vastustivat lähinnä epäitsenäisesti ajattelevat ja vahvan auktoriteettiuskon omaavat ihmiset. ${ }^{148}$ Schmoller oli korostuneen empiirisesti suuntautunut tutkija. Poliittisilta näkemyksiltään Schmoller oli aluksi liberaali, mutta vähitellen hänen ajattelunsa sai yhä konservatiivisempia piirteitä. ${ }^{149}$

Gyllingin väitöskirjan tekeminen sai kuitenkin väistyä toistaiseksi, sillä päteviä tilastomiehiä kaivattiin Suomessa. Kiinnostus yhteiskuntaa koskeviin tilastoihin lisääntyi 1800-luvun lopulla. Taustalla oli pyrkimys kartoittaa epäkohtia tilastoilla, jolloin niiden lieventäminen kävisi helpommaksi. Ajan henkeä kuvaa hyvin Otto von Bismarckin (1815-1898) toteamus, jota Hannes Gebhard lainasi: "Antakaa meille hyvä virallinen tilasto, niin me teemme hyvää politiikkiä". Säätyvaltiopäivätkin kiinnittivät kasvavaa huomiota sosiaalisiin ongelmiin. Vuonna 1900 valtiopäivät anoivat senaattia teettämään sosiaalisia ongelmia koskevia tilastollisia tutkimuksia. Senaatti perusti komitean selvittämään, miten työväen vanhuus- ja invalidivakuutusta voitaisiin kehittää. Komitean johtoon asetettiin Tilastollisen Päätoimiston johtaja August Hjelt (1862-1919). ${ }^{150}$

147 Heikkinen - Mauranen 1981, s.52; Heikkinen - Mauranen 1985, s.92-93.

148 KA, EGK, kansio 5, Edvard Gyllingin kirje Fanny Achrénille 5.6.1904.

149 Grimmer-Solem - Romani 1998, s.272.

150 Luther, Georg, Suomen tilastotoimen historia vuoteen 1970. Tilastokeskuksen tutkimuksia 205a. Helsinki 1993, s.90-93, 147. 
August Hjelt tarjosi kesäkuussa 1904 Gyllingille työtä, kun senaatin asettama komitea oli päättänyt aloittaa laajan tilastollisen tutkimuksen väestö-, invaliditeetti- ja tulosuhteista. Menetelmää kokeiltaisiin ensin muutamassa pitäjässä. Vähintään vuoden kestävää tehtävää varten tarvittiin pystyvä johtaja, joka saisi palkan valtioilta ja voisi samalla saada tieteellistä kokemusta. Hjelt tarjosi paikkaa Gyllingille toivoen, että tehtävä korvaisi keskeytyksen väitöskirjan teossa. Ilmeisesti se korvasi, sillä Gylling otti työn vastaan ja palasi Suomeen. ${ }^{151}$

Tehtävä sopi Gyllingille hyvin, sillä siinä yhdistyi yhteiskunnallinen analyysi konkreettiseen sosiaalipoliittiseen pyrkimykseen. Hänen johtamansa laajan selvityksen nimeksi tuli Väestö, invaliditeetti ja tulosuhteet Tuusulan, Humppilan, Kymin, Räisälän ja Vihannin kunnissa vuonna 1903, jotka olivat erilaisia ja eri puolilla Suomea olevia paikkakuntia. Tilastollinen selvitys ilmestyi kahtena laajana niteenä vuosina 1906 ja 1907. Tarkoituksena oli edistää työväenvakuutusta pysyvän työkyvyttömyyden varalta, joka johtui vanhuudesta tai jostain muusta syystä. Tilastojen keräämistä kokeiltiin ensin viidessä kunnassa, jonka jälkeen piti järjestää vastaava maanlaajuinen tiedustelu. Mitään laajempaa tutkimusta ei kuitenkaan tehty. ${ }^{152}$

Varsinainen tutkimustyö tehtiin kyselykaavakkeiden avulla. Tarkoitus oli koota tiedot kuntien koko väestöstä, joten kaavakkeet annettiin kaikille kunnassa vakinaisesti asuville henkilöille, jotka olivat ennen 1.1.1904 täyttäneet 16 vuotta. Lomakkeessa kysyttiin nimen, syntymäajan ja siviilisäädyn lisäksi muun muassa puolison ja lasten tiedot, ammatti- ja tulosuhteet, verotiedot sekä tietoja työkyvystä ja vakuutuksista. Maatalouden osalta kysyttiin vielä tietoja sadoista ja viljelystä. Gylling valitti sitä, ettei maatalousaineistoa analysoitu syvällisesti, vaikka niin olisi saatu lisätietoja. ${ }^{153}$

151 KA, EGK, kansio 1, August Hjeltin kirje Edvard Gyllingille 4.6.1904.

152 Gylling, Edvard, Väestö-, invaliditeetti- ja tulosuhteet Tuusulan, Humppilan, Kymin, Räisälän ja Vihannin kunnissa vuonna 1903 I, teksti-osa. Invaliditeettivakuutuskomitean julkaisu II. Helsinki 1907 (B), s.1-2; Peltonen 1992, s.47.

153 Gylling 1907 B, s.3; vrt. Heikkinen - Mauranen 1985, s.95. 
Tässä näkyy hänen asiantuntemuksensa maatalouskysymysten tutkijana ja kiinnostuksensa saada niistä vielä enemmän tietoa.

Työ ei ollut pelkästään Gyllingin tekemä, koska häntä avustivat palkatut aineistonkeräajät ja sen tarkasti erityinen valiokunta, johon kuuluivat Tilastollisen Päätoimiston johtaja August Hjelt, vakuutustarkastaja Onni Hallstén (1858-1937) ja tehtailija Viktor Julius von Wright. ${ }^{154}$ Gyllingin hakiessa myöhemmin dosentuuria tutkimus katsottiin kuitenkin hänelle suureksi ansioksi. ${ }^{155}$

Tutkimustyötä varten palkattiin 25 aineistonkerääjää, jotka kokosivat kirkonkirjoista, työnantajilta ja kotitalouksilta tietoja. Gylling yhdisti tiedot. Lomakkeita lähetettiin 17 800, joista 13 080 täytettiin. Ihmiset ryhmitettiin 28 eri ammattiin ja ammattiasemaan, jonka lisäksi vammaisuus ja sairaus otettiin erityisesti huomioon. Tutkimuksen lukuisista tuloksista mainittakoon seuraavat: miehillä oli keskimäärin selvästi naisia suuremmat tulot ja talollisten tulot olivat keskimäärin noin kaksi kertaa suuremmat kuin torpparin tulot. Muuhun maaseutuun verrattiin sellaisia tuloksia, joista oli saatavilla riittävästi vertailukelpoista tietoa. Näin saatiin selville esimerkiksi se, että tutkittavalla alueella tulotaso oli selvästi korkeampi kuin maaseudulla keskimäärin. ${ }^{156}$ Tutkimuksen toinen osa sisälsi pelkästään 50 taulukkoa. Senkin pituus oli kuitenkin yli 500 sivua. ${ }^{157}$

Tutkimuksessa analysoitiin väestön elinoloja monin tavoin. Siitä selvisi esimerkiksi kunnissa asuvan aikuisväestön demografinen ja yhteiskunnallinen rakenne ja huollettavien lasten määrä eri yhteiskuntaryhmissä. Kari Pitkäsen tavoin voi todeta tutkimuksen olleen niin perusteellinen, että invaliditeettiolojen selvitys jäi vain erääksi sivuteemaksi. ${ }^{158}$ Matti Peltonen puolestaan toteaa, että ko-

154 Gylling 1907 B, alkulause.

155 Helsingin Yliopiston Keskusarkisto (HYKA), Konsistorin ptk. 1.6.1910.

156 Gylling 1907 B, s.5, 11, 87, 93, 155.

157 Gylling, Edvard, Väestö-, invaliditeetti- ja tulosuhteet Tuusulan, Humppilan, Kymin, Räisälän ja Vihannin kunnissa vuonna 1903 II, taulukko-osa. Invaliditeettivakuutuskomitean julkaisu III. Helsinki 1906 (A).

158 Pitkänen, Kari, Väestöntutkimus ja yhteiskunta. Suomalaisen väestöntutkimuksen historia 1700 -luvulta noin vuoteen 1950 . Suomen väestöntutki- 
mitean keräämä perusaineisto on ainutlaatuinen, koska siinä kerättiin sellaisia maataloustuotantoa, tuotannon käytön rakennetta ja maatalousväestön tulonmuodostusta koskevia tietoja, joita ei missään muussa aikakauden lähteessä ole yhtä yksityiskohtaisesti ja kattavasti. ${ }^{159}$

Palattuaan Suomeen Gylling alkoi myös kirjoittaa ahkerasti lehtiin. Gyllingin ensimmäinen julkaistu kirjoitus on Nykyisestä siirtolaisuudestamme, joka julkaistiin useassa lehdessä vuoden 1904 lopulla. Gylling käsitteli siinä lyhyesti sekä Suomen sisäistä että ulkomaille - lähinnä Pohjois-Amerikkaan - suuntautunutta siirtolaisuutta. Artikkeliin sisältyi pieni historiallinen katsaus siirtolaisuuteen ja kaksi tilastoa. Hän totesi, että laaja siirtolaisuus maalta kaupunkiin käsittää pääosin tilatonta väestöä. ${ }^{160}$

Gylling kirjoitti artikkelille jatkoa, jossa hän eritteli siirtolaisuuden syitä. Tilastotietojen mukaan lähinnä vähävaraiset lähtivät siirtolaisiksi. Mäkitupalaisten ja lampuotien motiivina oli raha. Talollisten ja torpparien lapset lähtivät siirtolaisiksi pääosin varsin nuorena, koska tilat riittivät usein vain yhdelle lapselle, eivätkä muut halunneet joutua työläisiksi tai mäkitupalaisiksi. Gylling katsoi, että siirtolaisuuden syinä olivat taloudelliset olot ja vähemmässä määrin kansanluonteen vaikutus. Ainoa keino vähentää siirtolaisuutta oli parantaa maaseutuväestön taloudellisia oloja. ${ }^{161}$

Tieteellisessäkin keskustelussa oli vielä 1800-luvulla tavallista ajatella, että jokaisella kansalla oli sille ominainen kansanluonne. Ajatuksella on juurensa aiemmassa saksalaisessa romantiikassa. Myös Suomessa voimakkaasti vaikuttaneeseen hegeliläisyyteen käsitys sopi hyvin. Suomessa kansanluonnetta pyrittiin usein johtamaan lähinnä maantieteellisistä seikoista. ${ }^{162}$ Vielä tässä vaiheessa tämä traditio näkyi Gyllingin ajattelussa, kun hän katsoi

muksen historian julkaisuja n:o 11. Helsinki 1988, s.140.

159 Peltonen 1992, s.50.

160 Gylling, Edvard, Nykyisestä siirtolaisuudestamme. ks. esim. Satakunta 8.11.1904 (A).

161 Gylling, Edvard, Nykyisen siirtolaisuutemme syistä. ks. esim. Satakunta 19.11.1904 (B).

162 Suutala 1986, s.237. 
kansanluonteen yhdeksi syyksi siirtolaisuuteen. Kun Gylling siirtyi yhä enemmän korostamaan yhteiskunnallisia rakenteita ja taloudellisia syitä, tämä idealistiselta filosofiselta perustalta lähtevä tekijä jäi pois.

Vuoden 1905 alussa Gylling kirjoitti perintötorpista historiallisesta näkökulmasta. Hän totesi, että maanvuokraajien asema oli ollut polttavimpia yhteiskunnallisia kysymyksiä pari vuosikymmentä. Torpparilaitos syntyi 1700-luvun puolivälissä, kun hallitus huomasi että torppia perustamalla maan väkilukua ja ulkoista voimaa voitiin lisätä. Myöhemmin perintötorppajärjestelmä hävisi. Gylling kannatti sen palauttamista, koska se hidastaisi tilattoman väestön kasvua. ${ }^{163}$

Gylling suuntautui tutkijan uralle, jonka erityisenä kiinnostuksen kohteena oli maaseudun väestön tilanne ja asema. Hänen tutkijantyössään yhdistyi yhteiskuntatieteellinen ja historiallinen näkökulma, mutta keskeistä siinä oli tilastojen käyttö. Hänestä tulikin tilastojen ammattilainen. Vuodesta 1908 alkaen hän toimi tilapäisissä tehtävissä Tilastollisessa Päätoimistossa ja Tullihallituksessa, kunnes sai vuonna 1912 aktuaarin toimen Helsingin kaupungin tilastokonttorissa. Kun Helsingin kaupunki alkoi julkaista tilastollista vuosikirjaa vuonna 1908, Gylling toimitti sen vuosikerrat 1910-1915. Hänen työnsä tilastokonttorissa jatkui sisällissotaan asti. ${ }^{164}$

Tutkija Edvard Gylling erityisenä kiinnostuksen kohteena olivat maaseudun kysymykset sekä erityisesti tilattoman väestön ja maanvuokraajien asema. Häntä kiinnosti paitsi tutkimus myös asioihin vaikuttaminen ja näiden väestöryhmien aseman parantaminen. Gylling alkoikin toimia myös politiikassa, mikä vähitellen vei yhä enemmän hänen aikaansa.

163 Gylling, Edvard, Perintötorpista. Satakunta 26.8.1905 (D).

164 Heikkinen - Mauranen 1985, s.95. 


\section{Tie poliittiseksi vaikuttajaksi}

Sosiaalireformismia ja sosialismia

Suomen suuriruhtinaskunta oli ollut Venäjän keisarillinen autonominen osa vuodesta 1809 alkaen. Suomella oli itsenäistä lainsäädäntövaltaa, sisäinen keskus-, alue- ja paikallishallinto sekä oma raha vuodesta 1860 alkaen. Venäjä alkoi 1800-luvun lopulla harjoittaa yhä tiukempaa yhtenäistämispolitiikkaa, joka johti Suomessakin niin sanottuihin venäläistämistoimenpiteisiin. Ensimmäinen venäläistämiskausi alkoi vuonna 1899, kun keisari Nikolai II antoi suomalaisille helmikuun manifestin, jossa päätettiin tarkentaa asetuksia ja helpottaa Suomea koskevaa yleisvaltakunnallista lainsäädäntöä, vaikkakaan siinä ei puututtu suuriruhtinaskunnan sisäisten säädösten ja asetusten säätämisjärjestykseen. Suomalaisten aseman suhteen hankalin kohta manifestissa oli, että itsevaltias keisari Nikolai II pidätti itsellään täyden päätösvallan siitä mitkä asiat olisivat yleisvaltakunnallisen ja mitkä paikallisen lainsäädännön alaisia. Suomalaiset vastustivat näitä toimia monin eri tavoin. Vuonna 1899 uutta asevelvollisuuslakia vastustavaan suureen adressiin kerättiin noin 470000 allekirjoittajaa, mutta keisari ei ottanut sitä vienyttä lähetystöä vastaan. ${ }^{165}$

Edvard Gylling toimi monen muun nuoren ylioppilaan tavoin venäläistämispolitiikkaa vastaan aktiivisesti. Vuonna 1902 alettiin soveltaa uutta asevelvollisuuslakia, jonka perusteella suomalaisiakin kutsuttiin Venäjän armeijaan. Laittomiksi koetut kutsunnat aiheuttivat laajaa vastustusta ympäri maata. Gylling yritti organi-

165 Polvinen, Tuomo, Valtakunta ja rajamaa. N.I. Bobrikov Suomen kenraalikuvernöörinä 1898-1904. Juva 1985, s.45-51, 101-132. Ks. suuresta adresista yksityiskohtaisesti Tommila 1999. 
soida Ikaalisissa mielenosoitusta sitä vastaan, mutta menestys jäi varsin huonoksi. ${ }^{166}$

Suomalainen Puolue alkoi jakautua jo 1880-luvulla vanhasuomalaiseen ja nuorsuomalaiseen suuntaukseen. Suhtautuminen kiihtyneeseen venäläistämispolitiikkaan syvensi jakoa. Kärjistetysti voi sanoa, että vanhasuomalaiset edustivat myöntyväisyyslinjaa ja nuorsuomalaiset kannattivat passiivista vastarintaa. ${ }^{167}$ Gylling kuului myös suomenmielisten ylioppilaiden muodostamaan Suomalaiseen Nuijaan, joka edusti lähinnä vanhasuomalaisten vasemmistoa. ${ }^{168}$ Gylling suhtautui menettelytapakiistaan kuitenkin varsin sovittelevasti, sillä loppuvuodesta 1903 kirjoittamassaan kirjeessä hän lähinnä valitteli suomalaisten epäyhtenäisyyttä. ${ }^{169}$ Gylling opiskeli vuonna 1904 helmikuusta heinäkuuhun Berlii-

166 Suomalaisen Kirjallisuuden Seura, kirjekokoelma, Edvard Gyllingin kirje Heikki Ojansuulle 30.7.1902.

167 Jako ei todellisuudessa ollut näin yksiselitteinen. Helmikuun manifestin jälkeen muodostui neljä venäjänpoliittista linjaa: Koskisen ehdoton alistuminen, Danielsonin suhteellinen alistuminen, Ståhlbergin suhteellinen vastarinta ja jyrkkien perustuslaillisten ehdoton vastarinta. Koskisen kuoltua vuonna 1903 vanhasuomalaisten linjaksi vakiintui Danielsonin linja. Ks. tarkemmin Rommi, Pirkko, Myöntyvyyssuunnan hahmottuminen Yrjö-Koskisen ja Suomalaisen Puolueen toimintalinjaksi. Historiallisia Tutkimuksia 68. Helsinki 1964, s.342-345; Torvinen, Taimi, J. R. DanielsonKalmari Suomen autonomian puolustajana. Porvoo 1965, s.275-280; Vares, Vesa, Vanhasuomalainen Lauri Ingman ja hänen poliittinen toimintansa. Juva 1996, s.42-43.

168 Salomaa, Erkki, O. W. Kuusinen. Teoksessa Tiennäyttäjät 3. Toim. Soikkanen, Hannu. Rauma 1968, s.357.

169 KA, EGK, kansio 5, Edvard Gyllingin kirjeet Fanny Achrénille 26.9.1903 ja 2.12.1903; Klaus A. Järvinen kertoo Fanny Achrénin isää Alarik Ahcrénia huolestuttaneen jo vuonna 1903 Gyllingin vasemmistolaisuus. Kyseessä lienee kuitenkin muistivirhe, sillä kaikesta päätellen Gyllingistä tuli varsinaisesti vasemmistolainen vasta paria vuotta myöhemmin. Tosin jo tuolloin hänellä saattoi olla tiukan perustuslaillista Achrénia enemmän ymmärrystä sekä nousevaa työväenliikettä että myöntyväisyyspolitiikkaa kohtaan. Achrénin mielestä tämä tietenkin saattoi olla huolestuttavaa vasemmistolaisuutta. Järvinen, Klaus A. J., Edvard Gylling, Älykäs idealisti, jonka kohtalo ajoi sosialismin syöveriin. Teoksessa Edvard Gylling 1881-1991. Ikaalinen 1991, s.17. 
nin yliopistossa. On erittäin vaikeaa sanoa, mikä hänen poliittinen kantansa oli tuolloin ja vaikuttiko matka siihen jollakin tavalla.

Ylioppilaiden kiinnostus sosialismia kohtaan kasvoi Forssan kokouksen jälkeen. Marraskuussa 1903 Sulo Wuolijoki alustikin yhdistyksen kokouksessa sosialismista. Hämäläisen osakunnan kokouksessa, missä muodostuikin seuraavan vuoden aikana hänen johtamansa sosialistinen ryhmittymä. Myös muissa osakunnissa oli asiasta kiinnostuneita ylioppilaita, kuten Viipurilaisen osakunnan Yrjö Sirola (1876-1936, aikaisemmin Sirén). ${ }^{170}$ Gylling kuului Savo-Karjalaisen osakuntaan, joka ei ollut yhtä radikaali kuin Hämäläinen osakunta. Gylling oli kuitenkin epäilemättä tutustunut sosialistisiin aatteisiin vuosina 1903-1904 jo siitäkin syystä, että Sulo Wuolijoki oli hänen pitkäaikainen ystävänsä. Hella Wuolijoki korostaa lisäksi Sulon vanhemman veljen Väinö Wuolijoen suurta vaikutusta Gyllingin ajatteluun noina vuosina. ${ }^{171}$

Sosialistisen ajattelun ja poliittisen työväenliikkeen perustan muodostivat Karl Marxin ja hänen tukijansa Friedrich Engelsin kirjoitukset. Marx ja Engels näkivät valtion ennen kaikkea jonkin luokan etujen ajajana. Tämän takia proletariaatin tärkein tehtävä olikin ottaa valta käsiinsä, jonka jälkeen siirtyminen uudenlaiseen, sosialistiseen yhteiskuntaan oli mahdollinen. Marx ja Engels katsoivat, että tämän jälkeen on mahdollista poistaa erot hallittavien ja hallitsijoiden välillä, joka lopulta tekee valtionkin tarpeettomaksi. He luonnostelivat joissakin kirjoituksissaan tulevan sosialistisen yhteiskunnan pääpiirteitä, mutta eivät antaneet sille kovin yksityiskohtaisia suuntaviivoja. ${ }^{172}$

170 Soikkanen, Hannu, Sosialismin tulo Suomeen. Porvoo 1961, s.211-214; Kuusisto, Seppo, Kansallishenkeen uskoen. Hämäläis-osakunnan historia 1. Helsinki 1978, s.242; Hella Wuolijoen mukaan hämäläisten ylioppilaiden kiinnostus sosialismiin oli peräisin Väinö Wuolijoen Saksasta ja Lauri af Heurlinin Ranskasta tuomista vaikutteista. Wuolijoki, Hella, Yliopistovuodet Helsingissä 1904-1908. Tapiola 1973, s.92.

171 Wuolijoki 1973, s.65, 92; Hodgson, John H., Otto Wille Kuusinen. Poliittinen elämäkerta. Helsinki 1974, s.15.

172 Hobsbawn, Eric. How to chance the world. Tales of Marx and Marxism. London 2012, s.83-85. 
Marxin historiallisen kehityksen teoria kiinnittyy kahteen peruskäsitykseen: luokkataistelun käsitteeseen universaalihistoriallisena moottorina sekä tuotantovoimiin ja tuotantosuhteisiin rakenneperiaatteina. Kolmantena keskeisenä tekijänä oli idea perustasta ja päällysrakenteesta. Sen mukaan historiallista kehitystä vie eteenpäin yhteiskuntien taloudellinen perusta, jolle kulttuuri, aatteet ja politiikka eli päällysrakenne ovat alisteisia. Toisaalta Marx ymmärsi yhteiskunnan monimutkaisena kokonaisuutena, eikä korostanut näiden sektorien erillisyyttä. Lisäksi hän korosti ihmisen aktiivista roolia historiallisen kehityksessä, joten myöhemmät tulkinnat kapitalismin automaattisesta romahtamisesta ovat ehkä yksinkertaistavia. Marx korosti myös erilaisten ajatusmallien historiallisuutta. ${ }^{173}$

Sosialismi tuli varsinaisesti Suomeen 1800- ja 1900-lukujen vaihteessa, kun työväenliike radikalisoitui ja omaksui marxilaisia käsityksiä. Forssan puoluekokouksessa vuonna 1903 Suomen Työväenpuolue muutti nimensä Suomen Sosialidemokraattiseksi Puolueeksi ja hyväksyi uuden puolueohjelman. Esikuvina olivat Karl Kautskyn kirjoittama ja Saksan Sosialidemokraattisen Puolueen vuonna 1891 hyväksymä Erfurtin ohjelma sekä Itävallan sosialidemokraattien kymmenen vuotta myöhemmin hyväksymä Wienin ohjelma. Forssan ohjelman periaateohjelma on suoranainen käännös Wienin ohjelmasta, kun taas valtiolliset reformivaatimukset ovat kieltolakivaatimusta lukuun ottamatta lainaa Erfurtin ohjelmasta. ${ }^{174}$

Suomen sosialidemokraatit hyväksyivät marxilaisuuden samaan aikaan, kun Saksan sosialidemokraattien piirissä kritiikki Marxin teorioita kohtaan kasvoi. Niitä asettui puolustamaan Karl Kautsky, josta tuli marxilaisuuden johtava teoreetikko Saksassa

173 Schanz 1996, s.92, 113-119; Hänninen, Sakari, Marxin talous. Teoksessa Talous ja yhteiskuntateoria 1. Vanhan maailman talous ja suuri murros. Toimittanut Heiskala, Risto - Virtanen, Akseli. Helsinki 2011, s.232-236, 254-265.

174 Borg, Olavi, Suomen puolueideologiat. Periaateohjelmien sisältöanalyyttinen vertailu sekä katsaus niiden historialliseen taustaan ja syntyprosessiin. 2. painos. Helsinki 1965 (B), s.61-68; Soikkanen 1975, s. 44-50. 
ja samalla kansainvälisessä työväenliikkeessä. Kautsky painotti kapitalismin romahduksen synnyttämän vallankumouksellisen tilanteen odottamista ja parlamentaarista toimintaa, mutta vältti kompromisseja porvarillisten ryhmien kanssa. ${ }^{175}$ Eduard Bernstein puolestaan katsoi, että kapitalismi on osoittautunut joustavammaksi kuin Marx ajatteli, joten hänen teorioitaan on uudistettava. Bernsteinin mukaan todellinen kehitys ei tue pääomien kasautumisteoriaa eikä teoriaa työläisten jatkuvaa kurjistumista, joten kapitalismi ei ehkä tulekaan romahtamaan. Bernstein kannatti yhteistyötä porvarillisten liberaalien kanssa yhteiskunnan demokratisoimiseksi ja sosiaalisten reformien toteuttamiseksi. Saksan sosialidemokraattien valtavirtauksena säilyi kautskylainen keskusta, joka painotti teorian ja käytännön tiivistä yhteyttä. ${ }^{176}$ Sen haastajina olivat Bernsteinin johtama revisionistinen oikeistosiipi, joka painotti oikeansuuntaisia käytännöllisiä uudistuksia sekä Rosa Luxemburgin (1870-1919) johtama vasemmistosiipi, joka kannatti aktiivista vallankumouksellista toimintaa. ${ }^{177}$

Kautskylaisten ja revisionistien kiista alkoi toden teolla vuonna 1898 ja oli voimakkaimmillaan Saksan sosialidemokraattien Dresdenin puoluekokouksessa syyskuussa 1903. Maataloudella oli tässä kiistassa keskeinen asema. Bernstein totesi, että teollisuus ja kauppa osoittavat hitaampaa kehitystä kohti suurtuotantoa kuin

175 Kautskyn näkemyksistä tarkemmin Gronow, Jukka, On the Formation of Marxism. Karl Kautsky, s Theory of Capitalism, the Marxism of the Second International and Karl Marx,s Critique of Political Economy. Commentationes Scientiarum Socialium 33. Helsinki 1986, s.31, 45-46. Gronow korostaa, että Kautskyn fatalismia ja determinismiä on usein liioiteltu. Kautskyn mukaan vallankumous ei ollut automaattinen, vaan vaati tietoista, sosialistista ja organisoitua työväenluokkaa. Toisaalta Kautsky oli varma sosialismin voitosta, koska se oli ainoa vaihtoehto epäonnistuneelle kapitalismille.

176 Rautio 1994, erit. s.142-150, 159, 169-174.

177 Toisaalta on huomattava se, että Rosa Luxemburg kritisoi vahvasti leninismiä ja Venäjän vallankumousta. Tästä tarkemmin esim. Rautio, Veli-Matti, Puolalainen, juutalainen, vallankumouksellinen nainen: Rosa Luxemburg: Haik 2/1999, s.135-147; Markku Hyrkkänen on kirjoittanut Bernsteinin ajattelun käytännöllisyydestä oivaltavasti. Ks. Hyrkkänen, Markku, Revisionismin synty - aatehistoriallinen kausaaliongelma. Sosialistinen politiikka 4/1979, s.36. 
on oletettu mutta maanviljelyksessä kehityksen suunta näyttäisi olevan jopa päinvastainen eli pienviljelys lisääntyisi. Hän perusteli tätä tilastollisella aineistolla, jossa käsiteltiin Saksan ja Britannian tilojen kehitystä 1800-luvun lopulla. ${ }^{178}$ Marxin teoria tuotannon keskittymisestä ja pääomien kasautumisesta ei siis näyttänyt pitävän paikkaansa.

Karl Kautsky puolusti Erfurtin ohjelman linjauksia sen vuoden 1904 painokseen lisätyssä alkulauseessa ja käsitteli myös teoreettiseksi erityisen vaikeaksi osoittautunutta maatalouskysymystä. Kautsky myönsi, että maataloudessa pääomien keskittyminen näyttäisi pysähtyneen, mutta tilastoaineisto on liian epämääräinen, että pienviljelyksen voisi yksiselitteisesti sanoa lisääntyneen. Lisäksi hän totesi ikään kuin varmuuden vuoksi, että vaikka pienviljelys lisääntyisikin, niin sekään ei vielä kaataisi Marxin teorian perustaa, koska pientilat ovat joka tapauksessa yhä vahvemmin riippuvaisia suurtiloista. Tämän uuden pienyrittäjien luokan asema on jopa heikompi ja turvattomampi kuin palkkatyöläisten. Kautsky jopa totesi, että pienviljelys on välttämätöntä maatalouden kehitykselle, koska sitä kautta suurtuotanto saa köyhälistöä käyttöönsä helposti ja varmasti. ${ }^{179}$

Vaikuttaa siltä, että Gyllingillä - sen paremmin kuin muillakaan ylioppilailla - ei vielä tuolloin ollut kovin laajaa sosialistisen teorian tuntemusta. Gylling alkoi kuitenkin jäsentää kantaansa sosialistiseen ajatteluun, ensin yleisemmin historianfilosofiselta ja teoreettiselta kannalta ja sen jälkeen vähitellen myös oman erikoisalansa eli maatalouden kysymysten kautta. Tämä askel oli luonteva, koska puhdasoppisten marxilaisten ja revisionistisen välisessä kiistassa maatalouden tuotannon kehityksellä oli keskeinen sija.

Gyllingin tuolloisten yhteiskuntateoreettisten näkemysten kannalta erityisen valaiseva kirjoitus on Kapitalistisesta tuotannon järjestyksestä nykyaikana, jonka hän kirjoitti vuonna 1905 Kansantaloudellisen Yhdistyksen julkaisemaan Yhteiskuntatalo-

178 Bernstein 1982, s. 90-96.; Rautio 1994, s.117-142.

179 Kautsky 1974, s.11-18. 
udelliseen Aikakauskirjaan. Gylling viittaa artikkelissa saksalaisen kansantaloustieteilijän Werner Sombartin (1863-1941) teokseen Der moderne Kapitalismus. ${ }^{180}$ Sombart oli opiskellut kansantaloustiedettä Berliinissä Gustav Schmollerin oppilaana, mutta arvosteli tätä myöhemmin konservatiivisuudesta. Sombart kiinnostui sosialistisista aatteista, mutta kritisoi Marxia ja Engelsiä vanhanaikaisesta hegeliläisyydestä ja vallankumousromantiikasta, vaikkakin toisaalta tunnusti heidän ansionsa taloudellisen ja yhteiskunnallisen kehityksen analysoijina. Sombart vaikutti merkittävästi revisionismin johtohahmon Eduard Bernsteinin käsityksiin. ${ }^{181}$ Sombartin teos Der Moderne Kapitalismus toi tieteelliseen keskusteluun käsitteen "kapitalismi", jonka sisältö on keskeisiltä osiltaan peräisin Marxilta, joka tosin ei itse käyttänyt tätä käsitettä. ${ }^{182}$

Tarkastelen Gyllingin kirjoittamaa artikkelia ennen kaikkea suhteessa Sombartin näkemyksiin, joihin hän itsekin viittaa artikkelin alussa. Hedelmällisiä vertailukohtia voidaan löytää myös Marxin teksteistä. ${ }^{183}$ Taustalla vaikuttaa tietysti edellä kuvatta sosialidemokraattien teoreettinen kiista ja näkemysero suhteessa

180 Vrt. Heikkinen - Mauranen 1985, s.93.

181 Töttö, Pertti, Werner Sombart ja kiista kapitalismin hengestä. Jyväskylä 1991, s.17, 27-28,32-36, 45,109-111, 230-235; vrt. myös Hietaniemi, Tapani, Max Weber ja Euroopan erityistie. Vertailevia sivilisaatiohistoriallisia tutkielmia. Tutkijaliiton julkaisu 90. Helsinki 1998, s.170-172. Myöhemmin Sombart etääntyi yhä kauemmas sosiaalireformismista kohti oikeistoa ja tuki muutaman vuoden jopa kansallissosialisteja.

182 Sombart analysoi vuonna 1902 ilmestyneessä teoksessaan Der Moderne Kapitalismus nykyaikaisen kapitalismin syntyä ja kehitystä usealta eri kannalla huomioiden taloudelliset, sosiaaliset ja aatteelliset syyt. Hän oli sitä mieltä, että kapitalismin synty oli monen historiallisen tekijän yhteensattuma. Töttö 1991, s.47, 114-115.

183 On kuitenkin huomattava se, että monien muiden merkittävien ajattelijoiden tavoin Marxin ajattelu muuttui ajan kuluessa. Marxin ajattelun kehittymistä tutkinut jakaa sen kolmeen päävaiheeseen: 1840-luvun puoliväliin painotus on työn käsitteen kritiikissä, noin 1845-1855 historiallinen materialismi oli keskeisellä sijalla ja tästä eteenpäin poliittisen taloustieteen kritiikki nousi etusijalle. Schanz, Hans-Jørgen, Karl Marxin teoria muurin murtumisen jälkeen. Helsinki 1996, s.92-93. 
Marxin teorioihin, jossa maatalouden kehitys oli tärkeässä roolissa.

Gyllingin mukaan kansantalous on kokonaisuus, minkä yksityistaloudet muodostavat toisiinsa kietoutuneina. Gylling katsoi, että nykyaikaisen kansantalouden synnyn ja edellytysten ymmärtäminen edellyttää historiallista tarkastelua. ${ }^{184}$ Sombart korosti myös sitä, että taloudellinen toiminta pitää ymmärtää kehittyvinä talousjärjestelminä. ${ }^{185}$ Historiallisen taustan korostaminen on tietenkin suurelta osin peräisin kansantaloustieteen historialliselta koulukunnalta, joka määritteli taloutta korostetun historiallisesti. ${ }^{186}$ Tässä ei tietysti ollut mitään ristiriitaa marxilaisen ajattelun kanssa.

Gyllingin mielestä kapitalistinen tuotantomuoto erotti toisistaan työn ja pääoman tuotannontekijöinä. Tuotannossa tarvittava pääoma kuului kapitalisteille, jotka pitivät työn tulokset ja maksoivat sovitun palkan työläisille. Gylling katsoi, että koska pieni vähemmistö omisti tuotantovälineet, tuotanto ei tapahtunut kulutuksen ja yleisen tarpeen mukaisesti. Kapitalistit eivät tarkastelleet pääoman käyttöä yhteiskunnan edun vaan mahdollisimman suuren voiton kannalta. Tällöin pääoma muuttuu tuotantovälineestä tuotannon päämääräksi. Gyllingin arvion mukaan kehittyneiden valtioiden tuotannosta noin kaksi kolmannesta perustui kapitalistiseen voitontavoitteluun. Kapitalistit pyrkivät maksimoidakseen voittonsa muuttamaan tuotannon niin nopeaksi ja halvaksi kuin mahdollista, mikä johtaa tuotannon järjestämisen ja koneistuksen nopeaan kehitykseen. Gyllingin mielestä kehitys viekin kohti suurtuotantoa. ${ }^{187}$ Tämä näkemys on sopusoinnussa Marxin esit-

184 Gylling, Edvard, Kapitalistisesta tuotannon järjestyksestä nykyaikana. Yhteiskuntataloudellinen Aikakauskirja n:o 3/1905 (C), s.116-117.

185 Töttö 1991, s.32. Sombart piti historiallisen taustan merkityksen oivaltamista Marxin suurimpana ansiona.

186 Hentschel, Volker, Produktion, Produktivität. Teoksessa Geschichtliche Grundbegriffe. Historische Lexicon zur politisch-sozialen Spreche in Deutschland. Herausgegeben von Otto Brunner, Verner Conze, Reinhart Koselleck. Band 5. Stuttgart 1984, s.22.

187 Gylling 1905 C, s.117-120. 
tämän kasautumisteorian kanssa ${ }^{188}$ ja siis linjassa kautskylaisen tulkinnan kanssa.

Gylling katsoi, että kapitalistit yrittävät minimoida palkat ja maksimoida työajan kun taas työntekijöiden pyrkimykset ovat päinvastaiset. Hänen mukaansa kapitalismi olikin yleisesti ottaen ristiriidassa kansanvaltaisten pyrkimysten kanssa. Tosin tämä ristiriita ei vallitse aina, koska joskus työajan lyhennys johti voittojen kasvuun ja palkkojen kohoaminen voi nostaessaan työväenluokan ostovoimaa olla kapitalismille edullista. Gyllingin mukaan näistä yksittäisistä tapauksista huolimatta pääoman ja työn välillä oli ristiriita. ${ }^{189}$

Gylling esittää näkemyksensä kapitalismin synnystä. Olennaista oli se, että rikkaat alkoivat käyttää omaisuuttaan lisäomaisuuden hankkimiseksi. Tämä kehitys alkoi siirtomaakaupasta, mistä se levisi muuhunkin kauppaan. Toinen tärkeä edellytys on 1700-luvun suuret keksinnöt, jotka aloittivat "suurenmoisen taloudellisen uudistus- ja kehityskauden". ${ }^{190}$ Gylling korosti siis varsin myönteisessä hengessä kapitalismin synnyttämää taloudellista muutosta. Tässä hän oli Sombartin - ja myös Marxin - linjoilla. Sombart tosin katsoi kapitalismin syntyneen Italiassa jo ristiretkien jälkeisenä aikana, joskin se myöhemmin kehittyi huomattavasti. ${ }^{191}$

Gyllingin mukaan tilastot tukivat Marxin keskittymisteoriaa, joka ilmenee erityisesti lisääntyvien trustien ja kartellien lisääntymisenä. Keskittymisen lisäksi toinen tärkeä tendenssi on teollisuuden alalla lisääntyvä erikoistuminen. Näistä tekijöistä johtuen joidenkin yksityisten tuotantolaitosten yhteiskunnallinen vaikutus kasvaa jatkuvasti. Kapitalismi on murtanut vanhat taloudelliset ja yhteiskunnalliset olot ja muodostanut uudet puitteet kehitykselle. Gylling näki kuitenkin merkkejä siitä, että se puolestaan

188 Vrt. esim. Marx, Karl, Das Kapital. Kritik der politischen Ökonomie. Hamburg 1867. Julkaistu sarjassa Marx, Karl - Engels, Friedrich, Gesamtausgabe. Zweite Abteilung. "Das Kapital" und vorarbeiten. Band 5. Berlin 1983, erityisesti s.457-494.

189 Gylling 1905 C, s.120-121.

190 Gylling 1905 C, s.121-122.

191 Töttö 1991, s.34-35. 
tulee ainakin osittain syrjäytymään uuden sosialistisen tuotantojärjestelmän tieltä. Se on voittanut alaa, yhtäältä kun kapitalismia on rajoitettu määräyksillä ja toisaalta kun valtion ja kunnan taloudellinen toiminta on lisääntynyt. ${ }^{192}$

Gylling hyväksyi kirjoituksessaan Marxin esittämät kasautumis- ja keskittymisteoriat, mutta hänen kantansa työläisten kurjistumisteoriaan jää auki, eikä hän näyttäisi uskovan kapitalismin romahdukseen vaan sen korvautumiseen osittain yhteiskunnallisemmalla tuotantotavalla. Gyllingin voi sanoa noudattaneen artikkelissaan varsin pitkälti Sombartin näkemyksiä, jotka pohjautuivat osin historialliseen kansantaloustieteeseen ja osin marxilaisuuteen. ${ }^{193}$ Sombartin ajattelu linkittyikin kansantaloustieteen historiallisen koulun ja marxilaisuuden välimaastoon tavalla, joka epäilemättä puhutteli Gyllingiä. ${ }^{194}$ Tämä merkitsi myös sitä, että Gyllingin näkemykset olivat joiltain osin lähellä myös revisionismin aatteellisen johtajan Eduard Bernsteinin ajattelua.

Vuonna 1905 Gyllingin kanta sosialidemokraattien teoreettisiin kiistoihin oli vielä epäselvä ja selkeä kanta Marxin revisiointiin muodostumatta. Toisaalta Gyllingin yleisempikin käsityksensä kapitalismin olemuksesta ja kehityksestä oli vasta hahmottumassa. Huomattavaa on myös se, ettei Gylling ottanut edellä mainitussa kirjoituksessa kantaa siihen omasta erityisalastaan eli maatalouden kehityksestä lähtien. Hänen maataloutta ja siinä toimivien ihmisten olosuhteita käsittelevät tutkimuksensa olivatkin varsin

192 Gylling 1905 C, s.122-126.

193 Töttö 1991, s.60. Werner Sombart lisäsi entistä tarkemman Marxin yhteiskuntateorian analyysin vuonna 1905 ilmestyneeseen viidenteen painokseen teoksestaan Sozialismus und soziale Bewegung. Sombart hyväksyi Marxin keskittymisteorian, missä kartellit ja trustit näyttelevät keskeistä sijaa. Sombart piti Marxin onnistuneimpana oivalluksena sitä, että kapitalismin kehittyminen teki tuotannon yhteiskunnallistumisen ja sosialismin päämäärän välttämättömäksi. Hänen mukaansa on virheellistä kuitenkin olettaa, että sosialismi voittaa itsestään. Sombart katsookin Marxin kasaantumis-, kurjistumis- ja romahdusteorioiden osoittautuneen yksiselitteisen vääriksi.

194 Erik Grimmer-Solem ja Roberto Romani ovat kirjoittaneet analyyttisesti aikakauden taloustieteellisten teorioiden suhteesta, jossa he sijoittavat Sombartin näin. Ks. tarkemmin Grimmer-Solem - Romani 1998, s.267-270. 
empiirisiä, vaikka vähitellen hän alkoi jäsentää niiden ympärille myös jonkinlaista teoreettista tai yleisempää viitekehystä. Se tuli kansainvälisen sosialidemokratian suunnasta. Vuoden 1905 suurlakolla oli siihen suuri merkitys, joten käsittelen tätä erittäin merkittävää tapahtumaa seuraavassa suhteellisen laajasti.

\section{Suurlakon radikalisoiva vaikutus}

Gylling siirtyi ilmeisesti kannattamaan sosialidemokraatteja vuoden 1905 aikana mutta jo ennen loppuvuoden suurlakkoa. Hän kuului niin sanottujen marraskuun sosialistien joukkoon eli nuorten akateemista sivistystä saaneiden henkilöiden joukkoon, jotka nousivat työväenliikkeessä esille suurlakon jälkeen.

Venäjällä oli koko 1900-luvun alun jatkuvia levottomuuksia ja vallankumouksellista liikehdintää, joka lisääntyi entisestään vuoden 1905 aikana. Teollisuuden lakot, poliittinen terrori ja talonpoikaislevottomuudet halvaannuttivat Venäjän paikallishallinnon varsin täydellisesti. Sotaväen lojaalius hallintoa kohtaan alkoi myös uhkaavasti rakoilla kesällä 1905. Lakot olivat varsin suunnittelemattomia ja nousivat enemmän paikallisista epäkohdista kuin vallankumouksellisten voimien poliittisen mobilisaation toiminnasta. Tilanne johti kuitenkin lokakuun 1905 puolivälissä koko valtakuntaa käsittäneeseen yleislakkoon, joka halvaannutti koko itsevaltiaan Venäjän hallintokoneiston. ${ }^{195}$

Suomen suurlakon ${ }^{196}$ edellytykset kypsyivät vuoden 1905 aikana. Monet kokivat, että taipumaton vastarinta ja joukkoliikkeet olivat pakottamassa Venäjän perääntymään hyökkäyksestään

195 Tikka, Marko, Kun kansa leikki kuningasta. Suomen suuri lakko 1905. Suomalaisen kirjallisuuden seuran toimituksia 1247. Helsinki 2009, s.47-58.

196 Skandinavian maissa työväenliikkeen eri suunnat käyttivät eri käsitteitä kuvaamaan sitä laajaa valtakunnallista työtaistelua, jota muualla Euroopasta suuntauksesta riippumatta kutsuttiin yleislakoksi. Skandinaviassa käsite yleislakko kuului nimenomaan syndikalistien ja syndikalismista vaikutteita saaneiden suuntausten käsitteistöön, kun taas sosialidemokraattinen työväenliike kuvasi samaa asiaa käsitteellä suurlakko. Siten Suomenkin vuoden 1905 lakko muistetaan nimenomaan suurlakon nimellä. Santonen, Arvo, 
Suomen autonomiaa vastaan. Lokakuun lopulla Venäjällä alkanut yleislakko levisi myös kaikkiin keisarikunnan ei-venäläisiin osiin, kuten Puolaan, Baltiaan ja Suomeen. Lakkoliikehdintä kohtasi Suomessakin siis otollisen ilmapiirin, vaikka eri poliittiset toimijat tavoittelivat osin eri asioita suurlakon kautta. Porvarillisille perustuslaillisille puolueille kysymys oli ennen kaikkea autonomian puolustamisesta, mutta työväenliike tavoitteli myös yhteiskunnallisia uudistuksia, joista tärkein oli äänioikeuden laajentaminen. ${ }^{197}$

Helsingissä ensimmäinen yleinen lakkokokous kutsuttiin rautatientorille 30.10.1905, jossa oli lähinnä työväkeä. Samana päivänä kokoontui ylioppilaskokous, jossa eri puolueita edustavat ylioppilaat väittelivät lakon luonteesta ja siihen osallistumisesta varsin myrskyisästi. Lopulta ylioppilaat päättivät liittyä lakkoon yksimielisesti kuultuaan, että venäläiset sotilaat ovat luvanneet olla ampumatta lakkolaisia käskyistä huolimatta. Kokouksessa muodostettiin ylioppilaiden lakkovaliokunta, johon tuli jokaisesta osakunnasta kaksi jäsentä. Osa jäsenistä oli lähellä sosialidemokraatteja, kuten Otto Ville Kuusinen ja K. H. Wiik. ${ }^{198}$

Gylling osallistui aktiivisesti suurlakon aikaiseen toimintaan muun muassa partioimalla ylioppilaskaartin mukana aseettomana ja toimimalla poliisipiirin päällikkönä. Hän teki myös muistiinpanoja. Gyllingin huomio kiinnittyi siihen, että kadut ja torit olivat täynnä kansaa, mutta tilanne oli melko rauhallinen. Kuitenkin perustuslaillisten kokouksessa oli "aika ajoin täydellinen sekasorto" ja ylioppilaskunnan kokouksessa vallitsi "sama mielten

Kansainvälinen I. Utopia ja vallankumous - työväenliike vuoteen 1945. Espoo 1988, s.98.

197 Alapuro, Risto - Stenius, Heikki, Kansanliikkeet loivat kansakunnan. Teoksessa Kansa liikkeessä, Toim. Alapuro, Risto et al. Vaasa 1987, s.40; Tikka 1995, s.59-75.; Tikka, Marko, Mitä tapahtui? Teoksessa Kansa kaikkivaltias. Suurlakko Suomessa 1905. Toim. Haapala, Pertti et al., Jyväskylä 2008, s. $15-22$.

198 Tikka 2009, s.80-83. 
kuohu". Gylling myös partioi aseettomana ylioppilaskaartin mukana, mutta mitään erikoista ei tapahtunut. ${ }^{199}$

Suurlakko päättyi 4.11.1905 keisarin julkaisemaan marraskuun manifestiin, jossa helmikuun manifestin mukaiset asetukset kumottiin ja luvattiin kutsua valtiopäivät koolle. Useimpien muiden aikalaistensa tavoin Gylling tulkitsi keisarin perääntymisen perustuslaillisen politiikan voitoksi:

Suomelle on koittanut suuri ja valoisampi päivä. Laillisuus on voiton vienyt ...parempi seurata lain ja omantunnon ääntä kuin konjunktuuripolitiikkaa. Nyt on taas toivoa, että vankat, säännölliset olot palaavat, tuhat kertaa eläköön. ${ }^{200}$

Työväki jatkoi kuitenkin vaatimuksiaan yhteiskunnallisten reformien - kuten yleisen ja yhtäläisen äänioikeuden - toteuttamiseksi. Ylioppilaskokous päätti erota kansalliskaartista, koska osa siitä oli kehittynyt työväen punakaartiksi, joka halusi jatkaa lakkoa. Ylioppilaskaarti hajotettiin lopullisesti suurlakon päätyttyä Suomessa 6.11.1905. ${ }^{201}$

Gylling totesi, että työväki oli muuttumassa vallankumoukselliseksi, mutta onneksi "kypsyneet miehet Leo Mechelin, Lennart Gribenberg ja R. A. Wrede" johtivat kaikki lailliselle tielle. Työväki oli kuitenkin viime kädessä voiton takana, joten oli aika siirtyä yleiseen ja yhtäläiseen äänioikeuteen sekä parantaa muillakin tavoin työväen oloja. Gylling katsoi, että jatkamalla lakkoa työväki olisi mahdollisesti saanut tavoitteensa läpi. Hänen mukaansa se olisi toisaalta ollut epäloogista laillisuutta tähdentävän perustuslaillisuuden kannalta, minkä lisäksi olisi syntynyt suuri riski menettää autonomia. Gylling penäsi työväeltä malttia ja piti todennäköisenä, että vuoden kuluttua työväellä on samat oikeudet kuin

199 KA, EGK, kansio 3, Gyllingin muistiinpanoja suurlakon ajalta; Myös Kuusinen toimi ilmeisesti poliisipiirin päällikkönä. Salminen, Vesa, Estetiikan opiskelijasta poliitikoksi vuosina 1900-1906. Teoksessa Nuori Otto Ville Kuusinen1881-1920. Toim. Salminen, Vesa. Jyväskylä 1970, s.40

200 KA, EGK, kansio 3, Gyllingin muistiinpanoja suurlakon ajalta.

201 Klinge, Matti, Ylioppilaskunnan historia 3. Porvoo 1968, s.270-271, 278. 
muillakin. Hän muistutti, ettei missään Euroopassa ollut vielä yksikamarista valtiopäiväjärjestystä, eikä kaksikamarinenkaan ollut mikään "aristokraattinen systeemi". ${ }^{202}$ Tässä ajatuskulussa näkyy se, että tuolloin esille noussut ajatus siirtyminen yksikamariseen valtiopäiväjärjestykseen oli toteuduttuaan hyvin radikaali muutos.

Gylling suhtautui hieman kaksijakoisesti työväenliikkeeseen. Hän kannatti työväen vaatimuksia, joskin oli valtiopäivien yksikamarisuuden hyödyllisyydestä epävarma tai piti sitä ainakin epärealistisena tavoitteena. Hän ei kuitenkaan hyväksynyt vallankumouksellisuutta, vaan kannatti maltillista reformipolitiikkaa.

Gyllingin kirjoitusten sävy oli paikoin hyvin isänmaallinen. Hän kirjoitti, että ylioppilaskokouksessa suurlakon päätyttyä vallitsi isänmaallinen innostus ja totesi varsin patrioottiseen sävyyn isänmaan olevan "kaikille yhteinen, kaikille yhtä rakas ja kallis". ${ }^{203}$ On huomattava myös se, että Suomen autonomiaa uhkaava keisarillinen Venäjä oli kaikilla mittapuilla vanhoillinen järjestelmä, jolla oli omat voimistuvat vastustajansa emämaassakin. Tästä johtuen kansallisen retoriikan yhdistäminen yhteiskunnallisen uudistumisen vaatimuksiin oli varsin ongelmatonta. ${ }^{204}$

Suomessa katsottiin yleisesti, että suurlakon päättyminen voitokkaasti oli passiivisen vastarinnan ja perustuslaillisen linjan ansiota. Kyse oli kuitenkin perspektiivivirheestä, sillä voitto ei olisi ollut mahdollista ilman Venäjän huonoa sotamenestystä, jonka tuloksena koko keisarikunnassa esiintyi vallankumouksellista liikehdintää. Työväenliikkeessä suurlakon lopputulos herätti suoranaista katkeruutta, sillä liikkeen johto oli syrjäytetty tapahtumien ratkaisuun vaikuttaneista neuvotteluista. ${ }^{205}$ Toisaalta suurlakon

202 KA, EGK, kansio 3, Gyllingin muistiinpanoja suurlakon ajalta.

203 KA, EGK, kansio 3, Gyllingin muistiinpanoja suurlakon ajalta.

204 Antti Kujalan mukaan SDP:n Forssan kokouksessa vuonna 1903 hyväksymä marxilainen internationalismi jäi yleensäkin ainakin suurlakkoon asti kuolleeksi kirjaimeksi. Kujala, Antti, Venäjän hallitus ja Suomen työväenliike 1899-1905, Historiallisia Tutkimuksia 194, Helsinki 1995, s. 414; vrt. myös Jussila, Osmo, Nationalismi ja vallankumous venäläis-suomalaisissa suhteissa 1899-1914. Historiallisia tutkimuksia 110. Helsinki 1979, s. 23-24.

205 Soikkanen, Hannu, Vuoden 1905 tapahtumat ja niiden taustakehitys suomalaisen tutkimuksen näkökulmasta. HAik 1966, s. 92; Kujala 1995, s. 416. 
esimerkki osoitti työväelle, että se kykeni järjestäytymään yhteiskunnallisesti. Tätä kautta sen oli mahdollista ohjata yhteiskunnallista kehitystä ja myös omaa toimintaansa valtakunnallisella tasolla. Tämän jälkeen työväki ei enää ollut vain yhteiskunnallinen objekti, vaan itsenäisesti toimiva subjekti. ${ }^{206}$

Suurlakko sinetöi Gyllingin siirtymisen radikalisoituneen työväenliikkeen riveihin, mikä tuli yllätyksenä hänen morsiamelleen Fanny Achrénille. Heidän välillään käytiin suurlakon jälkeen sivistynyttä keskustelua suurlakon tuloksista ja työväen vaatimusten oikeutuksesta. Gyllingin ja Achrénin käsitysten eroavaisuus oli samankaltainen kuin yleisemmällä poliittisella tasolla. Porvarillisten perustuslaillisten tavoin Achrén katsoi, että suurlakossa oli ollut kysymys vain kansallisesta taistelusta. Gylling puolestaan korosti myös yhteiskunnallisten uudistusten tarpeellisuutta.

Gyllingin mielestä suurlakon tulokset olivat erinomaisia, mutta huonoa oli perustuslaillisten aiheuttama välirikko työväen kanssa. ${ }^{207}$ Achrén puolestaan epäili, että työläiset eivät vastustaneet "ryssän tuloa" niin voimakkaasti kuin pitäisi. ${ }^{208}$ Gylling korosti, että suurlakon tulokset eivät olisi toteutuneet ilman työväen joukkovoimaa. Hänen mielestään vallitsevassa yhteiskunnassa työläisten taloudellinen asema oli huono ja mahdollisuudet sen parantamiseen olivat vähäiset. Tästä johtuen oli ymmärrettävää, että työväki pyrkii uudenlaiseen yhteiskuntaan. Tärkein uudistus oli yleinen äänioikeus, mihin porvarillisetkin puolueet olivat taipumassa. Gylling katsoikin, että ajaessaan työväenluokan asiaa työväenliike osittain hyödytti koko yhteiskuntaa. ${ }^{209}$

Sekä Fanny Achrén että Edvard Gylling arvostelivat vanhasuomalaisten myöntyväisyyspolitiikkaa hyvin voimakkaasti, mut-

206 Tikka 2009, s.270-272.

207 KA, EGK, kansio 5, Edvard Gyllingin kirje Fanny Achrénille 6.11.1905.

208 KA, EGK, kansio 5, Fanny Achrénin kirje Edvard Gyllingille 8.11.1905. Tämä Achrénin lähettämä kirje oli päivätty kaksi päivää myöhemmin kuin Gyllingin hänelle lähettämä. Todennäköisesti tämä kirje ei vielä ollut tullut Achrénille, mikä saattoi vaikuttaa hänen lähettämänsä kirjeen sisältöön.

209 KA, EGK, kansio 5, Edvard Gyllingin kirjeet Fanny Achrénille 22.11.1905, 26.11.1905, 3.12.1905 ja 8.12.1905. 
ta edellinen ei hyväksynyt itsenäistä työväenliikettä. Achrénin mielestä voi olla työläisten puolella olematta perustuslaillisia ja ruotsalaisia vastaan. Kaikki nämä ryhmät olivat kansallisuustaistelussa mukana mutta vanhasuomalaiset eivät olleet. ${ }^{210}$ Achrénin ajattelussa passiivisen vastarinnan ja myöntyväisyyspolitiikan välinen ero oli edelleen keskeinen jakolinja, joten hän hyväksyi myös passiivista vastarintaa kannattaneet sosialidemokraatit oikealle puolelle. Gylling sen sijaan erotteli perustuslaillisista porvareista työväenliikkeen, koska tämä ajoi myös radikaaleja yhteiskunnallisia uudistuksia.

Vuoden 1905 Suurlakon merkitys suomalaisen yhteiskunnan ilmapiirille oli valtava. Perustuslaillisille porvarillisille puolueille suurlakossa oli ollut kysymys ennen kaikkea taistelusta autonomian puolesta, joten heidän näkökulmastaan sen tulos oli onnistunut. Sosialidemokraateille suurlakossa oli ollut kysymys myös taistelusta yleisen ja yhtäläisen äänioikeuden puolesta, joten sen tulos oli pettymys, joka tosin kääntyi valtiopäiväuudistuksen myötä voitoksi. Suurlakko oli tappio ennen kaikkea myöntyväisyyslinjaa edustaneille vanhasuomalaisille, joiden linja kärsi siinä selvän tappion. ${ }^{211}$

Suurlakko merkitsi kuitenkin myös paitsi poliittisia voittoja niin myös kokonaan uusien mentaalisten käsitysten ja rakennelmien muodostumista ja avautumista. Kun työväki esiintyi, toimi ja ilmaisu vaatimuksiaan suurlakossa, Jumalan asettamaan säätyjakoon tukeutuva ajattelu murtui lopullisesti. Tämä aikalaisajattelussa tapahtunut valtava murros oli ehkä suurlakon suurin vallankumous. Laajemmin katsoen Suomen suurlakko voidaan myös liittää osaksi Venäjän itsevaltiuden hajoamisprosessia, joka saavutti lakipisteensä vuosina 1905-1906. ${ }^{212}$

210 KA, EGK, Fanny Achrénin kirjeet Edvard Gyllingille 17.11.1905 ja 24.11.1905.

211 Tikka 2009, s.266-269. Ks. tarkemmin suurlakon häviäjien näkökulmasta. Vares, Vesa, Suurlakon häviäjät. Teoksessa Kansa kaikkivaltias. Suurlakko Suomessa 1905. Toim. Pertti Haapala, Olli Löytty, Kukku Melkas, ja Marko Tikka. Jyväskylä 2008, s.349-367.

212 Tikka 2008. s.16, 41. 
SDP:n jäsenmäärä alkoi suurlakon jälkeen nousta erittäin nopeasti ja puolueen linja tuli entistä radikaalimmaksi. ${ }^{213}$ Tämä sai monet sivistyneistön edustajat ottamaan etäisyyttä työväenliikkeeseen, mutta Gylling asettui selvästi tukemaan työväenliikkeen vaatimuksia yhteiskunnallisista uudistuksista, joten suurlakon jälkeen hän oli kiistatta sosialisti. Tämä oli sivistyneen säätyläisperheen lapselta varsin poikkeuksellinen ratkaisu, mihin voidaan etsiä taustatekijöitä. Monessa yhteydessä on väitetty, että Gyllingin ajatteluun vaikuttivat myöhemminkin ratkaisevasti hänen kouluaikaiset ystävänsä Sulo Wuolijoki ja Otto Ville Kuusinen. Kuusisen on jopa katsottu olleen johtajahahmo, jonka vanavedessä Gylling ja Wuolijoki ajautuivat sosialismiin. Arvo "Poika" Tuominen on puolestaan korostanut Kuusisen ja Gyllingin luonteiden erilaisuutta. Edellisellä oli taipumusta hyökkäävään fanaattisuuteen, kun jälkimmäinen oli aina rauhallinen ja viileä tiedemiestyyppi. ${ }^{214}$ Hella Wuolijoki katsoo sen sijaan, että Gylling oli yliopistovuosinaan Sulon vanhemman veljen Väinö Wuolijoen poliittinen oppilas. ${ }^{215}$

Tämän kaltaiset vaikutussuhteet ovat kuitenkin ainakin jossakin määrin kaksisuuntaisia. Lisäksi myöhemmän kehityksen valossa on vaarana erityisesti Kuusisen roolin ja vaikutuksen liioittelu, joskin hänellä varmasti oli vahvoja johtajaominaisuuksia. Ystävät vaikuttavat toistensa käsityksiin, mutta tämän vaikutuksen nostaminen henkilön aatteellisen valinnan päämotiiviksi aliarvioi yksilöä. Jos Gylling olisi tulkinnut tapahtumia täysin eri tavoin kuin esimerkiksi Kuusinen tai Sulo Wuolijoki, heidän ystävyytensä olisi todennäköisesti heikentynyt. Näin ajaudutaan ke-

213 Soikkanen 1975, s.117-120. Sami Suodenjoki on kuvannut tätä kehitystä hyvin paikallisella tasolla eli Urjalassa. Ks. tarkemmin Suodenjoki, Sami, Kuriton suutari ja kiistämisen rajat. Työväenliikkeen läpimurto hämäläisessä maalaisyhteisössä 1899-1909. Bibliotheca Historica 129. Helsinki 2010, s.219-221.

214 KA, AYK, kansio 2, Seija Mannisen tekemiä haastatteluja, Arvo "poika" Tuomisen haastattelu selkä Gerda Järvisen ja Lauri Järvisen haastattelu; Järvinen 1991. s.18; vrt. kuitenkin Tanner, Väinö, Nuorukainen etsii sijaansa yhteiskunnassa. Helsinki 1948, s.309.

215 Wuolijoki 1973, s.92. 
häpäätelmään: samanlaiset mielipiteet lähentävät henkilöitä, mikä puolestaan yhtenäistää mielipiteitä. Tämän kehän ympäriltä on kuitenkin löydettävissä yhteiskunnallisia, poliittisia ja aatteellisia tekijöitä, jotka veivät kolmikon monen muun nuoren ylioppilaan tavoin kohti sosialismia. Tätä todistaa sekin, että Martti Kovero, joka oli kolmikon läheinen ystävä lyseoaikoina, ei lähtenyt mukaan politiikkaan vaan virkamiesuralle.

Gyllingin pro gradu -tutkielman aiheella oli todennäköisesti suuri vaikutus hänen käsityksiinsä. Kouluaikojen romanttiset ja idealistiset käsitykset muuttuivat sitä tehdessä realistisempaan ja kriittisempään suuntaan. Tosin Ikaalisissa maatyöväen asema oli parempi kuin Suomessa keskimäärin, mutta Gylling näki myös siellä vakavia epäkohtia. Näiden ongelmien ratkaisemiseen sosialismi näytti tarjoavan paremmat lähtökohdat kuin porvarillinen sosiaalireformismi. Gyllingin tutkimustyössä vahvistui samalla marxilainen näkökulma, mutta sille oli edelleen tyypillistä vahva empiirinen ote, jolle teoriat olivat alisteisia.

Gylling oli looginen ja rationaalinen tiedemies. Tällaista ihmistä sosialismi saattoi kiinnostaa, koska marxilaisuus korosti omaa tieteellisyyttään vastakohtana porvarilliselle epätieteellisyydelle. Tosin käytännössä sosialismin innostavassa sanomassa oli myös paljon tunteeseen vetoavia elementtejä, jotka todennäköisesti vetosivat Gyllingissä myös olevaan idealistiseen puoleen.

\section{Poliittisen vaikuttamisen ensiaskeleet}

Helsingin yliopiston rehtori R. A. Wrede kielsi perustamasta sosialististen ylioppilaiden kaavailemaa Ylioppilaiden Sosialidemokraattista Yhdistystä (YSY). Kiellosta huolimatta kymmenkunta ylioppilasta perusti yhdistyksen 12.3.1905 salaiselta pohjalta. Sen jäsenmäärä kohosi vuoden 1905 loppuun mennessä 40 henkilöön. ${ }^{216}$ Yhdistyksestä tuli tärkeä foorumi sosialidemokraattisille

216 Reuna, Risto, Sivistyneistön tulo Suomen vanhaan työväenpuolueeseen. Suomen Sosialidemokraattisen puolueen ensimmäinen sivistyneistösukupolvi. Pro gradu. Helsingin yliopisto 1978, s.88-90. Yhdistystä perustamas- 
ylioppilaille, kuten Edvard Gyllingille. Hänen lisäkseen yhdistyksessä toimivat muun muassa Väinö Wuolijoki, Yrjö Sirola, Väinö Tanner, Väinö Hakkila (1882-1958), Julius Ailio (1872-1933) sekä Gyllingin vanhat koulutoverit Sulo Wuolijoki, Otto Ville Kuusinen ja Martti Kovero, joka ei kuitenkaan myöhemmin osallistunut SDP:n toimintaan. ${ }^{217}$

Gylling oli YSY:n jäsen, mutta hänen liittymisajankohdastaan ei ole saatavissa varmaa tietoa. ${ }^{218}$ Hella Wuolijoki muistelee, että Gylling oli toiminnassa mukana lähes alusta alkaen ${ }^{219}$, mikä on varsin uskottava väite. Joka tapauksessa hän oli yhdistyksen varapuheenjohtajana vuoden 1906 helmikuusta lokakuuhun.

Vaikka yhdistyksen jäsenet kuuluivat nuoren älymystön kärkijoukkoon, he tuskin olivat ainakaan ennen suurlakkoa kovin hyvin perillä sosialismin teoriasta. Suomessa varsin harva oli vielä tuolloin perehtynyt marxilaiseen sosialismiin. Työväenliikkeen piirissä teoreettista sosialistista tietämystä oli lähinnä N. R. af Ursinilla ja Edvard Valppaalla. Heidän lisäkseen muutamat porvarilliset sivistyneistön edustajat olivat lukeneet alan kirjallisuutta. Suurlakon merkitys oli tässäkin suhteessa suuri: sen jälkeen sosialistisen kirjallisuuden kääntäminen kasvoi suorastaan räjähdysmäisesti. ${ }^{220}$ Samalla työväenliikkeen aatesisällössä alettiin koros-

sa ylioppilastalolla olivat puheenjohtajana toiminut Työmiehen toimittaja Eero Haapalainen, Sulo Wuolijoki, Otto Ville Kuusinen, Juho Timonen, Janne Valmari sekä aktivistit Timo Korpimaa, Väinö Toikka ja Pertti Uotila; Vrt. Tanner 1948, s.363-365.

217 Salomaa 1967, s.167; Hella Wuolijoki muistelee, että alkuinnostuksessa yhdistyksen toimintaan osallistui useita henkilöitä, jotka sanoutuivat myöhemmin irti sosialismista. Wuolijoki 1973, s.169.

218 Yhdistyksen pöytäkirjoja on käytettävissä vasta vuodesta 1906 alkaen. Arvo Ylärakkolan mukaan Gylling toteaa muistiinpanoissaan olleensa mukana perustamassa kyseistä yhdistystä jo vuonna 1904. Ylärakkola 1976, s.20. Kyseessä lienee kuitenkin muistivirhe, koska yhdistys perustettiin vasta vuonna 1905. On myös mahdollista, että Gylling olisi yrittänyt käynnistää yhdistystä jo vuoden 1904 puolella. Tämä on kuitenkin epätodennäköistä, sillä hän tuskin oli vielä tuolloin ajatusmaailmaltaan sosialistinen.

219 Wuolijoki 1973, s.95.

220 Ks. Sosialistisen kirjallisuuden suomentamisesta tarkemmin Ehrnrooth 1992, s.106-120. 
taa sosialismin teorian yhteyttä tieteen tuloksiin. Aatteesta tuli looginen kokonaisuus, jonka mukaan kehitys johtaa automaattisesti sosialistiseen yhteiskuntaan. Marxin teorian kautskylaista tulkintaa ei enää juuri kyseenalaistettu. ${ }^{221}$

Jari Ehrnrooth on analysoinut vanhan työväenliikkeen piirissä esiintyneitä aatteellisia virtauksia. Hallitsevana teoriana oli selvästi kautskylainen oikeaoppinen marxilaisuus, jonka johtavina tulkitsijoina olivat Valpas ja Kuusinen. Revisionismi ilmaantui opillisesti Suomeen vuonna 1910 Bernsteinin teosten kääntämisen myötä. Se ei kuitenkaan juuri saanut puhdasoppisia seuraajia, vaan SDP:n oikeistosiipikin edusti ennemmin reformistisesti painottuvaa kautskylaisuutta tai osuuskunnallista evolutionismia. Marxilaisuuden vasemmistolaisinta tulkintaa eli suoraviivaista vallankumouksellisuutta kuten radikaalia anarkismia, syndikalismia tai leninismiä esiintyi Suomessa varsin vähän. ${ }^{222}$

YSY järjesti alustuksia ja keskusteluja erilaisista yhteiskunnallista aiheista. Gylling alusti yhdistyksen kokouksessa huhtikuussa 1906 kysymyksestä maanomistus vastaan maanvuokraus. Hän kannatti ennemmin maanvuokraajien aseman parantamista kuin omistusoikeutta, koska tilojen osto olisi tullut valtiolle erittäin kalliiksi. Gylling alusti samassa kokouksessa myös kansainvälisestä työväenlainsäädännöstä pohjanaan nuorsuomalaisen Heikki Renvallin (1872-1955) näkemykset. Hän yhtyi Renvallin kantaan, jonka mukaan työväenlainsäädäntö olisi nopeasti uusittava. ${ }^{223}$

Maaliskuussa 1907 Gylling esitelmöi yhdistyksessä eri maiden invalidivakuutuksista. Saksassa pääpaino oli työkyvyttömyysvakuutuksessa kun taas Ranskassa painotettiin eläkettä. Gylling kannatti molempien yhdistämistä, kuten useassa maassa oli tehtykin. Toinen kysymys oli, onko työväenvakuutus vai kansanvakuutus parempi. Jälkimmäisestä pääsisi osalliseksi vasta, jos tulot alittaisivat sovitun rajan. Saksassa oli työväenvakuutus, mutta Ruotsissa ja Norjassa oli ehdotettu kansanvakuutusta. Kolmas tärkeä kysy-

221 Soikkanen 1961, s.113.

222 Ehrnrooth 1992, s.184-189.

223 Työväen Arkisto (TA), Ylioppilaiden Sosialistisen Yhdistyksen (YSY), ptk. 29.4.1906. 
mys oli, mitkä olisivat työntekijöiden ja -antajien maksuosuudet. Gylling ei ottanut kantaa kahteen jälkimmäiseen kysymykseen. ${ }^{224}$

Gylling pääsi YSY:ssä keskustelemaan yhteiskunnallisista kysymyksistä sosialismin hengessä, mutta aatteen levittämiseen tarvittiin laajemmalle ulottuva foorumi. Tällaiseksi perustettiin Sosialistinen Aikakauslehti. Gyllingistä tuli sen päätoimittaja, Kuusisesta toimitussihteeri sekä Wuolijoesta ja Sirolasta muut toimittajat. Lehti käsitteli teorian, politiikan ja yhteiskunnan kysymyksiä varsin laajasti. Sen vallitsevana linjana oli lähinnä oikeaoppinen marxilaisuus. Toisaalta käsiteltäessä ajankohtaista kysymystä erilaisista vaalijärjestelmistä lehteen oli suomennettu sekä Karl Kautskyn että Eduard Bernsteinin käsityksiä. ${ }^{25}$ Tämän voi katsoa kuvastavan pyrkimystä jonkinlaiseen tasapuolisuuteen revisionismin ja marxilaisuuden välisessä kiistassa.

Sosialistisen Aikakauslehden ensimmäinen numero ilmestyi joulukuussa 1905. Toimitus totesi tyytyväisenä, että käsitykset suomalaisesta sosialidemokratiasta olivat muuttuneet, kun "halveksitusta ja ivatusta räyhääjäjoukosta on tullut sangen merkitsevä puolue”. Nyt olikin aika perustaa julkaisu esittelemään koti- ja ulkomaisia poliittisia kysymyksiä. Toimitus ilmoitti noudattavansa "uusaikaisen sosialidemokratian n.k. marxilaista suuntaa" sekä vetosi työväestön, opiskelijoiden ja "kaikkien kansamme taloudellista vaurastumista, valtiollista vapautumista ja yhteiskunnallista edistymistä samalla pohjalla harrastavien" tukeen. ${ }^{226}$

Sosialistinen Aikakauslehti noudatti lähinnä kautskylaista linjaa. Revisionismia Suomessa ei juuri esiintynytkään, mutta Suomeen palannut Matti Kurikka edusti idealistista sosialismikäsitystä, jossa luokkataistelu tuomittiin ja uskottiin edistykseen

224 Työväen Arkisto (TA), YSY, ptk. 24.3.1907.

225 Kautsky, Karl, Enemmistövaalit vai suhteellinen vaalitapa, Sosialistinen Aikakauslehti (SosA) 1906, s.28; Bernstein, Eduard, Enemmistövaalit vai suhteellinen vaalitapa, SosA 1906, s.52-53. Lehteen oli käännetty samasta kysymyksestä tekstejä myös neljältä muulta ulkomaiselta vaikuttajalta. He olivat August Bebel, G. von Vollmar, Chr. Hornsrad ja Hjalmar Branting.

226 Gylling, Edvard et al., Tarkotuksemme, Sosialistinen Aikakauslehti (SosA), näytenumero 1/ 1905 (A), s.1-2. 
tiedon lisäämisen ja yhteistyön kautta. Hänen ajattelunsa pohjautui vahvasti teosofiaan. Sosialistisessa Aikakauslehdessä tämä linja tuomittiin kovalla kädellä ja julistettiin tieteellinen lähestymistapa oikeaksi. Lehti antoi vahvaa taustatukea puolueen johdolle, joka veikin marxilaisen linjan läpi Oulun puoluekokouksessa vuonna 1906. Kurikka erosikin tämän jälkeen puolueesta. Gylling ei ollut kiistassa aktiivinen, mutta kaikesta päätellen hänen sympatiansa oli marxilaisen linjan takana. ${ }^{227}$

Sosialistinen Aikakauslehti lopetti toimintansa vain kolmisen vuotta aloittamisensa jälkeen. Lopettamisen syitä olivat taloudelliset vaikeudet ja toimittajien lisääntynyt työtaakka, kun kaikista neljästä tuli kansanedustajia. Myöhemmin onkin leikillisesti väitetty, että lehti olisi perustettu ennen kaikkea siksi, että he olisivat voineet kirjoittaa itsensä eduskuntaan. ${ }^{228}$ Ottamatta väitteeseen suoraan kantaa voi todeta sen, että Gylling kirjoitti Sosialistiseen Aikakauslehteen kymmeniä artikkeleja, katsauksia ja arvosteluja. Hän käytti kirjoittaessaan omaa nimeään tai nimimerkkiä E.G tai kirjoitti lyhyitä katsauksia nimettömänä.

Sosialistisen Aikakauslehden lakattua ilmestymästä vuonna 1908 Gylling ja Kuusinen panivat alulle puoluetoimikunnan julkaiseman Työväen Kalenterin, josta tuli varsin laajalevikkinen. ${ }^{229}$ Tämän lisäksi Gylling osallistui myös ruotsinkielisen Folktribunenin toimittamiseen. ${ }^{230}$ Varsinkin edellisestä tuli hänelle varsin tärkeä julkaisukanava.

Sosialistinen Aikakauslehti oli väline tieteen ja politiikan yhdistämiselle, jossa haettiin siis väylää teorian ja käytännön yhdistämiselle. Gylling käyttikin lehdestä luonnehdintaa "kansan-

227 Tästä tarkemmin Pollari, Mikko, Vihan ja sovun sosialistit. Teoksessa Kuriton kansa. Poliittinen mielikuvitus vuoden 1905 suurlakon ajan Suomessa. Tallinna 2009, s.81-103; vrt. myös Metsämäki, Mikko - Nisula, Petteri. Aktivistit. Suomalaisen kansalaisliikkeiden tarina, Helsinki 2006, s..37-56.

228 Salomaa 1968, s. 360; Salminen 1970, s.44.

229 Uimonen, Kirsi, Työväen Kalenteri työväenliikkeen poliittisten ja sivistyksellisten pyrkimysten kuvaajana vuosina 1908-1939. Pro gradu. Jyväskylän yliopisto 1991, s. 35.

230 Tuomioja, Erkki, K.H. Wiik. Itsenäisyysmies ja internationalisti. Elämäkerta vuoteen 1918. Helsinki 1979, s.43. 
tajuis-tieteellinen”. Hän julkaisi lehdessä tutkimustuloksiaan, haki tieteellistä perustaa sosialidemokraattisen liikkeen kannanotoille ja valisti kansaa. Linjansa mukaisesti Gylling korosti erityisesti tilastollista ja historiallista tarkastelutapaa. Aikakauslehdellä oli merkitystä myös marxilaisen teorian levittäjänä, joten toimittaessaan lehteä Gylling itsekin tutustui teoriaan tarkemmin. ${ }^{231}$

Suurlakon jälkeinen kehitys vei kohti valtiopäiväuudistusta. Kaikki puolueet olivat yksimielisiä uudistuksen välttämättömyydestä sekä periaatteesta, jonka mukaan äänioikeus muutettaisiin yleiseksi ja yhtäläiseksi. Erimielisyyttä oli kuitenkin uudistuksen sisällöstä ja toteuttamistavasta. Kiistakysymykseksi muodostui, tulisiko edustuslaitoksesta yksikamarinen vai kaksikamarinen. Sosialistit ajoivat edellistä mutta monet porvarit kannattivat jälkimmäistä. Tulokseksi tuli kompromissi. Eduskunnasta tuli yksikamarinen, mutta sen sisälle muodostettiin niin sanottu suuri valiokunta, mihin valittaisiin ansioituneimpia ja kokeneimpia edustajia. $^{232}$

Yksikamarisen eduskunnan työjärjestys oli pääpiirteittäin seuraava. Lähetekeskustelun jälkeen esitykset oli lähetettävä asiaa käsittelevään valiokuntaan, joka tekee esityksestä mietinnön. Sen jälkeen suoritettiin eduskunnan täysistunnossa ensimmäinen käsittely, joka sisältää periaatteellisen yleiskeskustelun ilman päätöksiä. Keskustelun päätyttyä mietintö oli lähetettävä suureen valiokuntaan, jos kysymyksessä oli lakiasia, suostuntavero tai uusi valtionlaina. Muut asiat voitiin eduskunnan tekemän päätöksen mukaisesti joko lähettää suureen valiokuntaan tai ottaa suoraan eduskunnan täysistuntokäsittelyyn. Suuren valiokunnan saatua mietintönsä valmiiksi se vietiin eduskunnan toiseen käsittelyyn, jossa tehtiin päätökset kohta kohdalta. Jos eduskunta tällöin teki mietintöön muutoksia, asia on palautettava suureen valiokuntaan. Jos eduskunta hyväksyy asian muuttumattomana, se tuodaan pian kolmanteen käsittelyyn. Tällöin eduskunta päättää asian lopullisesti yksinkertaisella enemmistöllä, mutta $1 / 3$ edustajista saattoi

231 Heikkinen - Mauranen 1985, s.94.

232 Seitkari, O., Eduskuntalaitoksen uudistus 1906. Teoksessa Suomen kansanedustuslaitoksen historia V. Helsinki 1958, s.10,26-34, 58. 
siirtää asian uusien vaalien jälkeen kokoontuville valtiopäiville, jolloin se on muuttumattomana joko hyväksyttävä tai hylättävä. ${ }^{233}$

Valtiopäiväuudistus oli kansainvälisesti ajatellen erittäin radikaali. Suomessa siirryttiin kertaheitolla vanhakantaisista säätyvaltiopäivistä yleisillä ja yhtäläisillä vaaleilla valittavaan yksikamariseen valtiopäiväjärjestykseen. Naisetkin saivat äänioikeuden ja vaalikelpoisuuden. Gylling oli epäilemättä tyytyväinen kehityksen yleissuuntaan, vaikka olikin suurlakon jälkeen todennut, ettei kaksikamarinenkaan järjestelmä välttämättä ole huono vaihtoehto.

Konservatiivisia piirejä pelotti rahvaan vaikutusvallan lisääntyminen. Kun liiallisen radikalismin pidikkeeksi ajateltu kaksikamarinen järjestelmä jäi toteutumatta, konservatiivien katseet kiinnittyivät vaalijärjestelmään. He näkivät suhteellisessa vaalitavassa järjestelmän, joka mahdollistaisi vähemmistönkin äänen kuulumisen. SDP ja Maalaisliitto kannattivat enemmistövaalitapaa, kun taas muiden puolueiden edustajat puolsivat suhteellista vaalitapaa. Lopulta suhteellisuuteen perustuva d'Hondtin vaalitapa hyväksyttiin. Myös kysymyksissä vaalioikeusrajasta ja vaivaisapua saavien äänioikeudesta SDP joutui antamaan periksi. Puolue halusi vaalioikeusrajaksi 21 vuotta ja äänioikeuden vaivaisapua saaville. Eduskuntakomitea kannatti näkemyksiä, mutta senaatti muutti ikärajaksi 24 vuotta ja jätti äänioikeuden ulkopuolelle mm. vaivaisavun varassa elävät, mielenvikaiset ja rangaistuslaitoksessa olevat kansalaiset. ${ }^{234}$

Valtiopäiväuudistuksen merkitystä tosin vähensi se, ettei keisarin valta kaventunut lainkaan. Vaikka valtiopäivät tuli kutsua vuosittain koolle, suuriruhtinas saattoi hajottaa ne tahtonsa mukaan. Lainsäädäntöaloite kuului sekä hallitsijalla että eduskunnalle, mutta jälkimmäisen aloite-oikeudelle oli asetettu erilaisia rajoituksia. Eduskunnalla ei ollut oikeutta tehdä aloitettava sellaisista asioista, jotka kuuluivat niin sanotun taloudellisen lainsäädännön piiriin, mutta keisari saattoi oma-aloitteisesti vaatia niistä eduskunnalta

\section{Seitkari 1958, s.57-59.}

234 Seitkari 1958, s.59-65, 81-85, 96-98, 138-141. Äänioikeuden rajoituksista tarkemmin Harjula, Minna, Kelvoton vaalikansalaiseksi. HAik 4/2006, s.368-381. 
lausuntoa. Eduskuntaesityksiä tehtiin vuosina 1907-1914 huomattavasti enemmän kuin hallituksen "armollisia" esityksiä. Kun valtiopäiväjärjestyksen mukaan keisarin ja suuriruhtinaan esitykset oli sekä täysistunnossa että valiokunnissa käsiteltävä ennen muita asioita, niin hallituksen esityksellä oli huomattavasti suurempi mahdollisuus tulla loppuun käsitellyksi kuin eduskunnan antaman esityksen. Lisäksi mikään laki ei astunut voimaan ilman keisarin vahvistusta, jonka hallituksen esitys sai tietysti paljon helpommin kuin eduskunnan. Eniten käytetty aloitemuoto eduskunnassa oli kuitenkin anomusehdotus, joiden kohteita eivät rajoittaneet mitkään erityismääräykset, vaan ne saattoivat koska myös lainsäädännön ulkopuolella olevia toimeenpanovallalle kuuluvia asioita, joille keisari soi huomiota halunsa mukaisesti. Kaiken kaikkiaan hallitsijan ehdoton veto-oikeus eduskunnan hyväksymiin lakiehdotuksiin oli siis siten autonomisessa Suomessa painava poliittinen realiteetti. Lisäksi eduskunnan mahdollisuus vaikuttaa valtion varainhoitoon oli varsin vähäistä. ${ }^{235}$

Gylling kirjoitti valtiopäiväuudistuksesta Sosialistiseen Aikakauslehteen vuoden 1906 alussa. Hänen mielestään senaatin tekemät muutokset merkitsivät kansanvaltaisuuden supistamista. Gylling kritisoi monin tavoin myös porvarienemmistöisen eduskuntakomitean alkuperäistä esitystä ja puolusti SDP:n ajamaa mallia. ${ }^{236}$ Joka tapauksessa uusi demokraattisesti valittu eduskunta lisäsi mahdollisuuksia yhteiskunnallisten ongelmien ratkaisemiseksi. Myös maatalouskysymykset ja maaseudun tilattoman väestön asema voitiin nyt nostaa uudella tavalla esiin.

235 Jansson, Jan-Magnus. Eduskunta ja toimeenpanovalta. Teoksessa Eduskuntatyö ja yhteiskunta 1907-1963. Suomen kansanedustuslaitoksen historia XII. Toim. Salervo, Olavi et al. Helsinki 1982, s.19-20.

236 Gylling, Edvard, Uusi vaalilakiehdotus, SosA 6/1906 (E), s.125-130. Gylling piti syntynyttä vaalitapaa liian monimutkaisena ja kannatti sitä, että äänestäjä äänestäisi vain yhtä ehdokasta. 


\title{
4. Sosialidemokraattien maatalouspolitiikan asiantuntija
}

\author{
Kautskylaisuus vai revisionismi?
}

Gyllingin keskeisin kiinnostuksen kohde sekä tieteellisesti että poliittisesti oli maatalouskysymys, sen historiallinen tausta ja synnyttämät sosiaaliset ongelmat. Etsiessään ratkaisuja maaseudun tilattoman väestön ongelmiin hän radikalisoitui ja liittyi nousevaan työväenliikkeeseen. Gyllingistä tulikin SDP:n maatalouspolitiikan johtava asiantuntija ja linjanvetäjä, jossa yhdistyivät sekä tieteellinen osaaminen että poliittinen johtajuus. SDP:n muita maatalouspolitiikan asiantuntijoita olivat maisteri Sulo Wuolijoki ja Oskari Tokoi, jolla ei tosin ollut akateemista koulutusta.

Olavi Aaltosen mukaan maisteri Väinö Wuolijoen rooli puolueen varhaisten maatalousohjelmien taustavaikuttajana oli määräävä. ${ }^{237}$ Väinö Wuolijoki oli tosiaan vuosina 1906-1910 yksi puolueen maatalouspolitiikan linjanvetäjistä ja aktiivista toimijoista. Kuitenkin näiden vuosien aikana puolueen johtavaksi maatalouspoliittiseksi asiantuntijaksi nousi Edvard Gylling, jonka toiminnassa yhdistyi sekä vankka tutkimuksellinen osaaminen että käytännöllinen työ muun muassa eduskunnassa ja maanvuokraajien kokouksissa.

Sosialidemokraattien maatalousohjelma yritettiin sovittaa puolueen yleisiin ohjelmallisiin linjauksiin ja tavoitteisiin, tosin vaihtelevalla menestyksellä. SDP:n johtava ideologi oli 1900-luvun alussa "vanhan työväenliikkeen paaviksikin" sanottu Edvard

237 Aaltonen, Olavi, Wuolijoki, Wäinö, Maatalous- ja finanssiasioiden erikoistuntija. Teoksessa Tiennäyttäjät 3. Suomen työväenliikkeen merkkimiehiä Ursinista Tanneriin. Toim. Soikkanen, Hannu. Rauma 1968, s.18-19. 
Valpas, joka nojautui vahvasti erityisesti Karl Kautskyn tekemiin "oikeaoppisen marxilaisuuden" linjauksiin. Valppaalla oli 1900-luvun alussa kilpailijoitaan enemmän marxismin tuntemusta ja sen edellyttämää kielitaitoa. Vuoden 1905 suurlakon jälkeen esiin nousseet nuoret, akateemisesti koulutetut "marraskuun sosialistit" asettuivat pääosin tukemaan Valppaan linjaa, joskin sitoivat sen entistä tiiviimmin marxilaiseen teoriaan. Otto Ville Kuusinen nousi vähitellen sosialidemokraattien teoreettiseksi johtajaksi, minkä takia häntä joskus kutsuttiinkin "pikku Kautskyksi". Tosin mitenkään kiistatonta Kuusisen johtajuus ei ollut, sillä erityisesti puolueen oikeistosiiven tulkinta poliittisista kysymyksistä poikkesi aika ajoin vahvastikin hänen näkemyksistään. ${ }^{238}$

Gylling nousi suurlakon jälkeisinä vuosina sosialidemokraattien maatalouspolitiikan linjanvetäjäksi. Hänen tehtävänsä ei ollut helppo, sillä teollisuuden kehityksen arvioiminen oli kansainväliselle työväenliikkeelle huomattavasti helpompaa kuin maatalouden kehittyminen, joka ei näyttänyt noudattavan Marxin keskittymisteoriaa. Suomen sosialidemokraateille maatalouden suuntaa koskeva ongelma oli erityisen tärkeä, koska Suomi oli 1900-luvun alussa vielä vahvasti maatalousvaltainen maa.

Vuonna 1899 Turussa perustettiin Suomen Työväenpuolue, jolle laadittiin samalla ensimmäinen tavoiteohjelma, jossa torpparien asema oli myös vahvasti esillä. Ohjelmassa vaadittiin maanvuokraehtojen parantamista monella eri tavalla, kuten 50 vuoden säätämistä lyhimmäksi vuokra-ajaksi, kirjallisia sopimuksia, korvauksia tehdyistä parannuksista ja kymmentuntista työpäivää. Työväenpuolueesta tuli näin maanvuokraajien aseman tuntuvaa parantamista vaativa ja torppareihin vetoava liike. Kahden vuoden päästä Viipurin puoluekokouksessa asiasta keskusteltiin periaatteellisemmalta kannalta, jolloin esille nousi kolme linjaa: maanvuokraehtojen parantamisen, torpparien itsenäistäminen pienviljelijöiksi ja sosialismin teoriaan vetoava kanta, joka tosin

238 Soikkanen1967, s.100-111; Salminen, Vesa, Laillisuuden esitaistelija vai oman edun tavoittelija - Kuusinen ja toinen sortokausi. Teoksessa Nuori Otto Ville Kuusinen 1881-1920. Jyväskylä 1970, s. 60-81; Soikkanen 1975, s.51-65, 122-124, 148-165. 
ei antanut selvää vastausta kysymykseen. Maatalouskysymyksestä ei kuitenkaan saatu aikaan periaatteellista yksimielisyyttä, joten puoluekokous tyytyi vain joihinkin käytännöllisiin ehdotuksiin. ${ }^{239}$

Vuoden 1903 Forssan puoluekokoukseen puoluehallinto laati pääasiassa Norjan työväenpuolueen ohjelman pohjalta viisi kohtaa käsittävän ehdotuksen, jonka keskeisenä tavoitteena oli sosialististen periaatteiden tuominen maatalousohjelmaan. Ehdotuksen keskeisinä ajatuksina oli yhteiskunnan omistuksen lisääminen ja maatalousosuuskuntien muodostamisen vauhdittaminen. Ehdotus sai osakseen ankaraakin kritiikkiä, ensinnä koska se lupasi torppareille paljon vähemmän kuin Turussa 1899 hyväksytyt ponnet ja toiseksi siksi, ettei maanviljelysosuuskunta-ajatusta pidetty elinkelpoisena. Maatalousohjelmasta käytiin paikallisyhdistysten käsittelyssä kipakkaa keskustelua ja siihen tehtiin paljon muutosesityksiä. Tampereen ja Pispalan työväenyhdistys laativat yhteisen ohjelmaehdotuksen. Myös Limingan työväenyhdistys laati oman ohjelmaesityksensä, jossa haluttiin tukea voimakkaasti itsenäistä pienviljelystä. $^{240}$

SDP:n vuoden 1903 Forssan kokouksessa hyväksymä maatalousohjelma muodostui lopulta pitkälti Tampereen ja Pispalan työväenyhdistysten ehdotuksen mukaiseksi. Forssan ohjelmaan tuli erillinen maatalousosa, jossa pyrittiin erilaisin keinoin saamaan valtion ja kuntien omistukseen lisää maata ja tiloja. Valtion omistavat maat piti antaa viljeltäväksi tilattomille tai osuuskunnille, mutta ei omistusoikeudella. Lisäksi valtion oli tuettava taloudellisesti pienviljelystä ja osuustoimintaa. Maanvuokraajille vaadittiin täydellistä käyttö- ja myyntioikeutta viljelystuotteisiinsa ja tehdystä työstä maksettavaa korvausta. Erillisohjelmassa vaadittiin myös metsästys- ja kalastusoikeuden tekemistä riippumattomaksi maanomistuksesta, maaseudun väestön sivistämistä ja palkollissäännön kumoamista. Toisaalta Forssan ohjelman periaatteellisen osassa todettiin, että taloudellisen vallan keskittyminen kapitalismissa vaikuttaa siten, että pikkutilalliset "menettävät tuotan-

239 Soikkanen 1975, s.43-44,49-50.

240 Soikkanen 1975, s.55-56. 
nonvälikappaleensa ja joutuvat milloin palkkatyöläisinä, milloin palkattuina apulaisina, milloin velkataakan alaisiksi sortuneina joko suorastaan tai välillisesti kapitalisteista riippuviksi." ${ }^{241}$ Forssan ohjelman periaatteellinen osa oli siis ristiriidassa varsinaisen maatalousohjelman kanssa, koska edellisessä todettiin kehityksen kulkevan kohti suurtuotantoa kun taas jälkimmäisessä tuettiin pienviljelystä.

Forssan ohjelman ristiriitaisuuden taustalla oli sosialidemokraattien piirissä yleisesti vallinnut epävarmuus maatalouden suunnasta, jonka taustalla oli Karl Kautskyn ja Eduard Bernsteinin välinen kiista. Kautsky korosti sitä, että sosialismi on ennen kaikkia tiedettä yhteiskunnasta ja sen lainalaisuuksista. Myös Bernstein hyväksyi tieteen suuren merkityksen, mutta painotti teorian alisteisuutta empirialle. ${ }^{242}$ Kautskyn kirjoittaman Erfurtin ohjelman mukaan suurtuotanto syrjäyttää kapitalismin kehittyessä pientuotannon. Hän kuitenkin myönsi, että maataloudessa tämä kehitys oli ollut odotettua hitaampaa ja paikoitellen pientuotanto oli jopa voittanut alaa. Kautskyn mielestä oli kuitenkin ennenaikaista päätellä, että Marx olisi pitkällä tähtäimellä ollut väärässä. Hän korosti myös sitä, että pienviljelijöiden asema oli heikkenemässä. ${ }^{243}$ Revisionistit puolestaan katsoivat, että todellisuus oli osoittanut keskittymisteorian ainakin maataloudessa vääräksi. ${ }^{244}$

Vuonna 1905 Gylling kirjoitti tästä vaikeasta kysymyksestä Sosialistiseen aikakauslehteen. Hän totesi, että vaikka teollisuuden merkitys on kasvanut viime aikoina, maanviljelijät ovat lähitulevaisuudessa suurin ja tärkein väestöryhmä. Hän myönsi, että

241 Suomen Työväenpuolueen toisen puoluekokouksen ohjelma on painettuna Borg 1965 A, s.31-36.

242 Schieder, Wolfgang, Sozialismus, Teoksessa Geschichtliche Grundbegriffe. Historische Lexicon zur politisch-sozialen Spreche in Deutschland. Herausgegeben von Otto Brunner, Verner Conze, Reinhart Koselleck. Band 5. Stuttgart 1984, s.955-957, 985-989; Gronow 1986, s.46-53; Rautio 1994, s. $177-180$.

243 Kautsky 1974(1891), s.13-14; Kautsky 1988 (1899), s.168-197.

244 Tarkemmin tästä Rautio1994, s.117-142. 
sosialisteille kanta maanviljelyksen kehitykseen oli varsin ongelmallinen. Gylling kallistui tässä vaiheessa varovaisesti revisionismin suuntaan. Hän nimittäin totesi, että saksalaisen sosialidemokraatin Eduard Davidin (1863-1930) teoksessaan Sozialismus und Landwirtschaft esittämä todistus pienviljelyksen vahvistumisesta oli vakuuttava. ${ }^{245}$

Myös Gylling painotti sosialismin tieteellistä taustaa. Hän kuitenkin katsoi, että ennen lopullista kannanottoa maatalouden kehityksestä pitäisi suorittaa paikalliset olot huomioiva tutkimus. Tämän jälkeen sosialistien ohjelma nojautuisi "järkähtämättömään tosiasiaan, tieteellisesti selviteltyyn yhteiskuntaolojen kehitykseen" ${ }^{246}$ Gylling korostaa empiirisen tutkimuksen merkitystä teorianmuodostukselle ja paikallisten olojen huomioimista tavalla, mikä muistuttaa Bernsteinin empiriasta lähtevää ajattelua.

SDP:n ohjelmassa oli vain yleisluontoisia huomautuksia maatalouden suunnasta. Gyllingin mukaan niistä ei ollut käytännön tasolla juuri hyötyä, koska niissä käsiteltiin varsin vähän Suomen maaseudun olojen pääkysymyksiä, maanvuokraajien ja tilattoman väestön oloja. Hänen mielestään sosialidemokraattien olisikin tehtävä ohjelma, jossa otettaisiin maatalouskysymyksiin kantaa sekä periaatteellisella että käytännöllisellä tasolla. Gylling katsoi, että tarvittiin "täydellisempiä suunnitelmia ja varmempaa asiankäsittelyä sekä jyrkemmin ja selvimmin lausuttuja vaatimuksia". ${ }^{247}$

Vuonna 1906 Gylling kirjoitti laajahkon artikkelin sosialismista ja maatalouskysymyksestä, missä hän käsittelee yksityiskohtaisesti maatalouden kehitystä, kansainvälistä sosialidemokraattista keskustelua ja SDP:n maatalousohjelmaa. Käsittelen tässä sitä varsin laajasti, koska se yhdistää Gyllingin empiirisen tutkimustyön teoreettisiin ja poliittisiin näkemyksiin sekä samalla täsmentää hänen omaa ajatteluaan. Kirjoituksen alussa Gylling määritteli sosialismin. Hän totesi, että käsitteen "sosialismi" runko merkitsee samaa kuin yhteiskunta. Tämä huomio sisältää sosialistisen liikkeen

245 Gylling, Edvard, Maatalouskysymys puolueohjelmassamme, SosA, näytenumero 1/1905 (B), s.14-15.

246 Gylling 1905 B, s.15.

247 Gylling 1905 B, s.16-17. 
pääpyrkimyksen: yhteiskuntatalouden pääpainon siirtäminen yksityisiltä henkilöiltä yhteiskunnalle. Kapitalismin valtaanpääsyn jälkeen sivistys ja valtiollinen vaikutusvalta jakautuivat yhä tasaisemmin, mutta taloudelliset erot kasvoivat entisestään. Tästä maaperästä syntyi sosialistinen liike. ${ }^{248}$

Gyllingin mukaan kapitalistisen talouden kehitys valmisti automaattisesti maaperää sosialistisille pyrkimyksille. Kapitalismin kehityksen keskeinen piirre oli keskittyminen, joka tosin on teollisuudessa havaittavissa paljon selvemmin kuin maataloudessa. Gylling katsoi, että suurtuotantolaitosten ja suurten maaomaisuuksien omistajat pyrkivät saamaan mahdollisimman suuria voittoja, jolloin suuria omaisuuksia käytettiin yhteiskunnalle turmiollisella tavalla. Hänen mukaansa olisi kuitenkin parempi, että yhteiskunta johtaisi kansantaloutta kokonaisuuden etua silmälläpitäen. Gylling katsoo, että olosuhteiden kehittyessä syntyy otollinen maaperä sosialismin vaatimukselle ottaa tuotantovälineet yhteiskunnan haltuun. ${ }^{249}$ Tämä kehityskulku vastaa marxilaista tulkintaa, missä kasvava ristiriita yhteiskunnallisen tilanteen ja vanhentuneitten tuotantosuhteitten välillä mahdollistaa sosialismiin siirtymisen. ${ }^{250}$

Gylling huomautti, että pienviljelyksen ollessa keskeinen elinkeino luokkaerot olivat lievempiä kuin teollisuusvaltaisessa yhteiskunnassa työläisen ja työnantajan välillä. Tästä johtuen pienviljelysvaltaisessa yhteiskunnassa ei vielä syntynyt sosialistiselle kehitykselle tarpeeksi "syvää luokkajakoa", eikä näin ollen myöskään "luokkatunnetta". 251 Gylling käytti tässä käsitettä "luokka" selvän marxilaisesti, jolloin luokka kehittyy tuotantovoimien mukaan historiaa muuttavaksi voimaksi, kunhan siitä tulee tietoinen luokkaeduistaan. Luokkien merkityksen historian kulussa hyväksyivät myös Sombart ja Max Weber (1864-1920), mutta he eivät kuitenkaan Marxin tavoin olleet vakuuttuneet työväenluo-

248 Gylling, Edvard, Sosialismista ja maatalouskysymyksestä, Kansan kalenteri II (julkaistiin 1907), 1906 (B), s.149-150.

249 Gylling 1906 B, s.150-151.

250 Gronow 1986, s.13-14.

251 Gylling 1906 B, s.151-152. 
kan historiallisesta tehtävästä kapitalismin kumoajana. ${ }^{252} \mathrm{Gyl}-$ lingin mukaan maanvuokraajat ja maatyöläiset voivat kannattaa sosialismia, mutta varsinaiset talonpojat eivät oikeastaan missään tehneet niin, minkä takia sosialismin toteuttaminen maaseudulla olisi vaikeaa. ${ }^{253}$

Gylling kirjoitti, että kansainvälisen sosialismin piirissä väiteltiin tilastojen pohjalta siitä, mihin suuntaan maanviljelys on kehittymässä. Marxilaisen teorian mukaan maataloudessakin pitäisi tapahtua keskittymistä. Toisaalta on osoitettu tilastojen avulla, että useassa Euroopan maassa pienviljelys oli edeltävinä vuosina lisääntynyt. Tosin myös varsinaisten suurviljelysten määrä usein lisääntyi samaan aikaan, joten ainoastaan keskikokoisten viljelysten määrä laski. Gylling totesi, että tämä oli johtanut kahteen vastakkaiseen näkemykseen: jotkut katsoivat pienviljelyksen lisääntymisen väliaikaiseksi ilmiöksi kun taas toisten mukaan pienviljelys oli kapitalismin oloissa suurviljelystä edullisempi ratkaisu. Tämän takia sosialistien piirissä oli epävarmuutta siitä, miten maanviljelyksen suhteen pitäisi toimia. ${ }^{254}$

Gylling totesi, että pienviljelyksen kannattajat vaativat yleensä laajemminkin muutoksia sosialistien ohjelmaan. ${ }^{255}$ Heidän mielestään tuotantovälineet pitäisi siirtää valtiolle osuustoiminnan avulla, koska se kasvattaessaan yhteishenkeä ja poistaessaan kapitalistisia piirteitä oli askel kohti sosialismia. Tämä suuntaus oli saanut kannatusta lähinnä Ranskassa ja Etelä-Saksassa, missä monet pienviljelijätkin tukivat sosialisteja. Gylling suhtautui osuustoimintaan myönteisesti, koska yhteisöllisenä tuotanto- ja

252 Walther, Rudolf, Stand, Klasse. Teoksessa Geschichtliche Grundbegriffe. Historische Lexicon zur politisch-sozialen Spreche in Deutschland. Herausgegeben von Otto Brunner, Verner Conze, Reinhart Koselleck. Band 6. Stuttgart 1990, s.267-269, 281-282.

253 Gylling 1906 B, s.152-153.

254 Gylling 1906 B, s.153-155.

255 Gylling tarkoitti tässä ilmeisesti suuntausta, joka 1890-luvun alussa nousi Saksassa esiin. Ns. Baijerilainen ryhmä Georg von Vollmarin johdolla ajoi pienviljelyn tukemista ja pienviljelijäin omistusoikeuden tunnustamista. Myöhemmin revisionismin johtaja Eduard Bernstein sai tältä ryhmältä tukea. Ks. Santonen 1988, s.78-79. 
kulutusjärjestelmänä se on "melkoinen askel kohti sosialismia". Toisaalta osuustoiminnan kannattajat eivät olleet vielä esittäneet, miten toteutetaan "maan yhteisomaisuudeksi" julistaminen. ${ }^{256}$

Gylling totesi, että SDP:n ohjelmassa oli seuraavat pienviljelystä suosivat kohdat: valtionapua pitäisi antaa erityisesti pienviljelystä ja osuustoimintaa edistäville toimenpiteille sekä valtion ja kuntien olisi toimittava siten, että viljelijät oppisivat tuntemaan maanviljelyksen uusimmat työtavat ja saisivat välttämättömät ammatilliset taidot. Gyllingin mukaan myös vaatimukset tilattoman väestön sivistämisestä ja palkollissäännön lakkauttamisesta suuntasivat kehitystä samaan suuntaan, joskin ne oli tarkoitettu yleisesti maatyöväen olojen parantamiseen. ${ }^{257}$

Gylling erotteli edellisistä ne, jotka eivät kannattaneet pienviljelystä, mutta kuitenkin uskoivat osuustoiminnan johtavan kohti sosialismia. Tämän näkemyksen mukaan maa pitäisi antaa työväen osuuskunnille, jotka viljelisivät sitä osuustoiminnallisten periaatteiden mukaisesti. Gyllingin mielestä vielä ei voinut sanoa, johtaisiko tämä parempaan tulokseen kuin teollisuudessa, missä se ei ollut toiminut. Tämä mielipide on kuitenkin lähempänä marxilaisuutta kuin varsinaisten pienviljelystä tukevien kanta. ${ }^{258}$ Tämä suunta oli saanut SDP:n ohjelmaan ainakin seuraavat vaatimukset: valtionapua oli annettava maanviljelyksessä kaikille osuustoiminnan luontoisille yrityksille sekä valtion hallussa olevat ja sille lunastettavat maat oli annettava tilattomille ja osuuskunnille, joiden jäsenet itse viljelivät maata. Gylling asettui kannattamaan näitä vaatimuksia, kuten hän totesi jo Matti Kurikankin tehneen. ${ }^{259}$

Gylling totesi, että oikeaoppisen marxilaisuuden edustajat korostivat, että pienviljelyksen edistyminen on tilapäistä. Heidän mukaansa suurviljelyksen voittokulku alkaa, kun kapitalismi pääsee vallitsevaksi maataloudessakin. Kuitenkin jo ennen sitä

256 Gylling 1906 B, s.155-157.

257 SDP:n maatalousohjelman kohdat 6 ja 9, painettu Borg 1965 (A), s.20-21; Kyseiset vaatimukset olivat maatalousohjelman kohdat 10 ja 11.

258 Gylling 1906 B, s.158.

259 SDP:n maatalousohjelman kohdat 5 ja 6, painettu Borg 1965 A, s.35-36.; Gylling 1906 B, s.159. 
viljelijöiden kasvava velkaantuminen ja vuokraviljelyksen yleistyminen johtavat viljelijöiden jakaantumiseen rikkaisiin ja köyhiin, joten luokkataistelu kärjistyy maataloudenkin alalla. Hän totesi tilastojenkin tukevan sekä vuokraviljelyksen että velkaantumisen kasvua. Tämän suunnan kannattajat vastustavat kaikkea yksityistä maanviljelystä, koska se vain hidastuttaa kapitalismin kehitystä. Gylling totesi, että Saksan sosialidemokraattinen puolue tukee tällaista linjausta, minkä takia varsinkin Pohjois-Saksassa talonpojat vastustavat jyrkästi sosialidemokraatteja. ${ }^{260}$

Gylling katsoi, että marxilainen ajattelu oli mahdollista yhdistää pienviljelystä korostaviin mielipiteisiin. Hänen mukaansa tilastot tukivat käsitystä velkaantumisesta ja vuokraviljelyksen lisääntymisestä sekä suurviljelyksen että vielä suuremmassa määrin pienviljelyksen osalta. Vaikka pienviljelys lisääntyisikin, niin lopulta maataloudessa oli teollisuuden tavoin pientä omistajajoukkoa vastassa suuri sorrettujen joukko. Gylling uskoi, että tässä tilanteessa yleinen mielipide tulisi kannattamaan maatalouden ottamista valtion haltuun. Tätä ennen yhteiskunnan pitäisi vielä kehittyä huomattavasti, mutta siihen oli kuitenkin valmistauduttava. Lopulta hän totesi että sosialismin edellytykset maanviljelyksessä ovat selvästi kehittymässä. ${ }^{261}$ Gylling oli epävarma siitä, lisääntyikö suurtuotanto maataloudessa. Toisaalta pienviljelys joutui joka tapauksessa yhä alistetumpaan asemaan. Gylling totesikin samana vuonna kirjoittamassaan lyhemmässä kirjoituksessa, että Suomessakin suurviljelys kannatti yleensä pienviljelystä huonommin. ${ }^{262}$

SDP:n Forssan ohjelman maatalousohjelmassa todettiin, ettei valtion ja kuntien omistamia tiloja saisi myydä eikä lahjoittaa mutta myytäväksi joutuneet maatilat, kosket ja kaivannot oli arvioidusta hinnasta otettava valtiolle. Lisäksi kunnille olisi saatava oikeus pakkolunastaa yksityisiltä maata tuotannon mukaan määrätyllä maksulla ja metsästys- ja kalastusoikeus on tehtävä riippumattomaksi maanomistusoikeudesta. Gylling kannatti näitä vaa-

260 Gylling 1906 B, s.160-163.

261 Gylling 1906 B, s.162-165; vrt. Kautsky 1899 (1988), s.303-307.

262 Gylling, Edvard, Torppariolojen uudistamisen johdosta, SosA 7/1906 (F), s.155. 
timuksia, jotka lisäisivät yhteiskunnan roolia maanomistuksessa. Hän tuki myös vaatimusta vuokralainsäädännön kehittämisestä, koska se valmisti maaperää sosialistiselle maankäyttötavalle. Gylling ilmoitti kannattavansa myös yleistä viljelyspaikkoa, mikä tarkoitti, että jos maanomistaja ei viljele viljelyskelpoista maataan, hänen on jätettävä se halukkaalle vuokraa vastaan viljeltäväksi. Tämän avulla tilattomat saisivat maata uudisasutukseen ja pienviljelijöille tulisi mahdollisuus viljelyksen suurentamiseen ${ }^{263}$ Gylling nosti tässä esille viljelyspakkovaatimuksen, josta tuli SDP:n seuraavien vuosien keskeinen maatalouspoliittinen vaatimus.

Sosialistiseen Aikakauslehteen kirjoittamassaan artikkelissa Gylling korosti, että puolueen maalaisohjelma sivuutti liian pintapuolisesti yksityisen maaomistuksen aiheuttamat epäkohdat sekä maanvuokraajien ja tilattoman väestön aseman. Gyllingin mukaan kapitalistinen kehitys Suomessa oli heikentänyt erityisesti maanvuokraajien asemaa, kun vuokraoikeus heikkeni ja vuokrat kohosivat. Mikäli maanvuokraaja ei suostunut huononnuksiin, seurasi häätö. Gyllingin mukaan tästä johtuen maanomistajien ja maanvuokraajien väliset ristiriidat olivat kasvaneet, mikä on synnyttänyt ikävää luokkavihaa. Gylling syytti kehityksestä suurtilallisia ja erityisesti metsäyhtiöitä. Hän totesi, että vaikka maanvuokraajat eivät olleet varsinaisesti palkkatyöläisiä, näiden kahden ryhmän edut olivat samansuuntaiset. Gyllingin mielestä omistavien luokkien johtama taloudellinen kehitys on molemmille luokille turmiollista. ${ }^{264}$

Gyllingin maatalouspoliittisen ajattelun täsmentämiseksi on kiinnostavaa verrata hänen käsityksiään maanvuokraajalaitoksesta porvarillisen tutkijan Aksel Warénin (1869-1899) vuonna 1898 julkaistussa teoksessa Torpparioloista Suomessa esittämiin näkemyksiin. Warén ei nähnyt torpparikysymyksen kärjistymisen taustalla niinkään taloudellista ja yhteiskunnallista kehitystä vaan torpparien poliittisen heräämisen. Warén kannatti uutta lainsäädäntöä, jolla parannettaisiin torpparien äärimmäisen epävarmaa

263 Gylling 1906 B, s.164-165.

264 Gylling, Edvard, Torpparit ja työväenliike, SosA 4/1906 (D), s.83-86. 
asemaa. Näin tapahtui, kun vuonna 1902 säädettiin maanvuokralaki. Warénin ajattelun keskeinen ero Gyllingiin verrattuna oli se, että hän uskoi tarpeellisten lakimuutosten jälkeen maanvuokraajien etujen olevan samansuuntaiset kuin maanomistajien, jolloin torpparilaitos voisi toimia tulevaisuudessakin. ${ }^{265}$

Gylling oli Warénia radikaalimpi, sillä hän totesi työväen ja maanvuokraajan asemasta seuraavasti: "Vasta sosialististen aatteiden valtaanpääsy voi lopullisen taloudellisen parannuksen aikaansaada, ottamalla tuotantovälineet, pääoman ja maan, sekä niitten käyttöoikeuden määräämisen yhteiskunnan haltuun." 266

Vuonna 1906 Gylling analysoi maatalouden kehitystä ja siitä käytyä keskustelua sekä Suomessa että laajemmin Euroopassa. Samalla hän määritteli oman kantansa sosialidemokraattien kiistassa siitä, miten maatalouden kehitystä pitää tulkita ja minkälaiseen politiikkaan sen suhteen pyrkiä. Gylling asettui loppujen lopuksi tukemaan kautskylaista näkemystä, jonka mukaan pientilojen määrän kasvusta huolimatta pienviljelys tuli yhä riippuvaisemmaksi kapitalismista. Näin hän omalta osaltaan vaikutti siihen, että Suomen sosialidemokraattien parissa revisionismi sai ainoastaan vähäistä kannatusta.

\section{SDP:n viljelyspakkovaatimus}

Vuoden 1905 suurlakon jälkeen sosialidemokraattien ja vanhasuomalaisten paikallisissa kokouksissa eri puolilla Suomea nousi yhä vahvemmin esiin ajatus maanvuokraajien maanlaajuisesta kokouksesta. Suomalaisen Puolueen piirissä kannatettiin ensin yhteistyötä sosialidemokraattien kanssa, mutta omaksuttiin pian kilpaileva asenne. ${ }^{267}$ Vuoden 1905 suurlakon aikana ja heti sen jälkeen sosialidemokraattien toimintaan tulvi uutta väkeä, jois-

265 Warén, Aksel, Torpparioloista Suomessa. Suomalaisen Kirjallisuuden Seuran toimituksia 89. Helsinki 1898, s.4, 20-21, 26, 402-405.

266 Gylling 1906 D, s.86.

267 KA, Suomalaisen Puolueen Arkisto, puoluekokousten ptk. 29-30.12.1905 ja 3.2.1906; Rasila 1961, s.290-298. 
ta suuri osa oli maaseudun tilatonta väestöä. SDP:n onnistuikin ottaa johto maanvuokraajien liikkeessä. ${ }^{268}$ Edvard Gyllingillä oli tässä erittäin tärkeä rooli.

Maanvuokraajien ensimmäinen maanlaajuinen edustajakokous pidettiin Tampereen työväentalossa 9-12.4.1906. Kokouksessa oli noin 400 edustajaa 302 paikkakunnalta, jotka valtakirjojensa mukaan edustivat noin 50000 maanvuokraajaa. Torpparien lisäksi mukana oli melko runsaasti mäkitupalaisia ja muutamia lampuoteja. Lisäksi työväenyhdistykset pyrkivät määrittelemään liikkeen suunnan, joten ne lähettivät kokoukseen runsaasti toimihenkilöitään. Heidän lisäkseen paikalla oli myös sosialidemokraattisen puolueen palkkaamia kiertäviä puhujia eli agitaattoreita. Kokouksen edustavuuden suhteen alueelliset erot olivat suuria. Parhaiten edustettuna oli Hämeen lääni ja heikoimmin Viipurin, Oulun ja Vaasan läänit, joissa oli vähiten maanvuokraajia. Kuitenkin kokous kattoi alueellisesti koko maan varsin hyvin. ${ }^{269}$

Puoluesihteeri Yrjö Sirola toivotti edustajat tervetulleeksi ja totesi, että maanvuokraajien etu pitäisi yhdistää kokonaisuuden etuun $^{270}$. Sirolan lausunto heijastanee pyrkimystä yhdistää sosialismin teoria ja maanvuokraajien omat toiveet mahdollisimman hyvin. Taustalla oli se tosiasia, että monet maanvuokraajat halusivat omaa maata, mikä marxilaisen teorian mukaan hidasti kehitystä kohti sosialismia.

SDP:n keskeistä asemaa maanvuokraajien puolestapuhujana ja vankkaa otetta maanvuokraajien liikkeestä osoittaa se, että kokouksessa myönnettiin täysi äänioikeus edustajien lisäksi puoluehallinnon jäsenille ja keskustelukysymysten alustajille sekä puheoi-

268 Soikkanen 1975, s.110-114; vrt. Hyvönen, Antti, Työväenliikkeen nousu Suomen torpparien pelastus. Teoksessa Suurlakkovuosi. Toim. Tuominen, Jussi et al., Kuopio 1955, s.128-131.

269 Rasila 1961, s.308-310; Soikkanen 1975, s. 114; Edustettavien täsmällistä lukua on mahdotonta antaa, koska valtakirjoissa lukuja on pyöristetty; vrt. Gylling, Edvard, Torpparikokous Tampereella, SosA 8/1906 (G), s.190-191.

270 Torpparien ensimmäisen yleisen edustajakokouksen ptk., Helsinki 1906, s.14-15. 
keus kaikille puolueen ja piirien agitaattoreille. ${ }^{271}$ Gylling sai näin täyden äänioikeuden, sillä hän alusti kokouksessa peräti kolme keskustelukysymystä.

Kokouksessa oli kymmenen keskustelukysymystä, joita jokaista valmistelemaan valittiin valiokunta. Gylling valittiin kolmeen valiokuntaan. Hän oli mukana valmistelemassa seuraavia keskustelukysymyksiä: "missä suhteessa olisi vuokramiehen viljelyoikeutta vuokratilaan laajennettava ja mitkä pykälät olisivat siinä tapauksessa uuteen maanvuokralakiin saatavat?"; "onko ja missä tapauksessa torppien nykyisille asujille tunnustettava oikeus korvaukseen jos heidät torpastaan häädetään jo ennen vuokralain uudistamista?"; "millä tavoin on uudisviljelystä valtion ja yksityisten mailla edistettävä?".272

Gylling totesi alustaessaan vuokramiehen viljelyoikeudesta, että sosialistien lisäksi "järkevimmät porvaritkin" pitivät vakinaista käyttöoikeutta parhaana ratkaisuna. Hänen mukaansa rajaton omistusoikeus oli aiheuttanut maanvuokraajien huonot olot, tilattoman väestön kysymyksen ja saanut talolliset myymään metsät liian tyhjiksi, mistä olivat hyötyneet vain maanomistajat ja metsäyhtiöt. Lisäksi metsän ja maan arvon nousu johti uudisviljelyksen entistä selvempään estämiseen. Gyllingin mielestä tilanne vaati maan omistusoikeuden vähittäistä rajoittamista lopullisena päämääränä tehdä maasta koko kansan omaisuutta. Maanvuokraajan kannalta omistusoikeus oli kuitenkin luonteeltaan varma, vapaa ja riippumaton, eikä vuokraoikeus voinut kilpailla sen kanssa, ellei se tarjoaisi yhtäläisiä mahdollisuuksia. Porvarilliset puolueet halusivat tehdä maanvuokraajista maanomistajia. Gyllingin mukaan tästä olisi seuraavat haittavaikutukset:

- se olisi hidasta, koska tarvittaisiin puolesta miljardista miljardiin markkaa.

- jäljellä olevien torpparien asema heikkenisi, mikä hajottaisi heidän rivejään.

271 Torpparien ensimmäisen yleisen edustajakokouksen ptk., Helsinki 1906, s.16-17.

27239 Torpparien ensimmäisen yleisen edustajakokouksen ptk., Helsinki 1906, s. 18 . 
- niiden torpparien, jotka eivät voi heti tilaa lunastaa, asema jäisi epävarmaksi.

- uudistus vaatisi niin paljon valtion varoja, että muut uudistukset olisivat lähitulevaisuudessa mahdottomia.

Gylling arvioi, että maanvuokraolojen uudistaminen puolestaan antaisi turvaa häädöiltä ja auttaisi tilatonta väestöä, jos kaikki viljelyskelpoinen maa jätettäisiin halukkaille viljeltäväksi silloisen lain säätämillä ehdoilla. ${ }^{273}$

Gyllingin johtama valiokunta kannatti siis ennen kaikkea uutta maanvuokralakia, jossa maanvuokraajan asema ja vuokraehdot olisivat huomattavasti vanhaa parempia. Toisaalta uudisasutusta sekä valtion harjoittamaa suurtilojen ostamista ja palstoittamista olisi jatkettava. Lisäksi Gylling kannatti alustuksessaan viljelyspakkoa, jonka mukaan kaikki se valtion ja yksityisten hallussa olevat viljelyskelpoinen maa, jota omistaja ei itse viljellyt, on jätettävä halukkaiden viljeltäväksi tulevan maanvuokralain ehdoilla. Gylling tuki myös maanvuokraajille täyttä metsänkäyttö- ja laidunoikeutta sekä metsästys- ja kalastusoikeuden tekemistä maanomistuksesta kokonaan riippumattomaksi. ${ }^{274}$

Kokouksessa syntyi eniten keskustelua torppien omistusoikeudesta. Suurin osa edustajista vastusti omistusoikeutta, mutta pohjanmaalaiset edustajat kannattivat sitä. He katsoivat, että omistusoikeus kannusti vuokraoikeutta paremmin työntekoon. Kokouksessa esiintyivät omistusoikeutta vastaan myös puolueen johtohenkilöt Heikki Jalonen (1865-?) ja Taavi Tainio (1974-199). Kokous päätyi kuitenkin vaatimaan perinnöllistä vuokraoikeutta murskaavalla enemmistöllä 337-27. Yhdeksän omistusoikeuden kannattajaa jätti mietintöön vastalauseensa. Maanvuokraajien keskuudessa yksityisen omistusoikeuden kannatus näytti siis olevan yllättävänkin vähäistä, mutta ilmeisesti näin selkeä äänestys-

273 Torpparien ensimmäisen yleisen edustajakokouksen ptk., Helsinki 1906, s.40-43; Rasila 1961, s.307-308.

274 Torpparien ensimmäisen yleisen edustajakokouksen ptk., Helsinki 1906, s.38-39, 43-48. 
tulos johtui osin puoluejohdon taitavasta taktikoinnista ja pontevasta käännytystyöstä. ${ }^{275}$

Torpparikokous hyväksyi lopulta seuraavat ponnet:

- maanvuokraajien asema on turvattava sekä vaadittava vapaata ja perinnöllistä asumisoikeutta viljelys- ja nautintaoikeudella.

- on velvoitettava maanomistaja joko viljelemään viljelyskelpoista maataan tai luovuttamaan sen vuokraa vastaan sellaiselle halukkaalle, jolla oli alle 25 hehtaaria maata.

- valtion omistamat sotilas- ja muut vastaavat torpat on muutettava valtiolle veroja maksaviksi tiloiksi; kirkollista virkataloista on tehtävä kunnan tiloja.

- valtion maita ei saa myydä eikä lahjoittaa, vaan ne on annettava tilattomille viljeltäväksi.

- valtion on avustettava uudisasutusta kuivaamalla soita. ${ }^{276}$

Varsinkin toinen ponsi on merkittävä, koska siinä SDP:n ajama yleinen viljelyspakko sai ensimmäistä kertaa selkeän tuen torppariliikkeen taholta. Gylling oli ajanut viljelyspakkoa pontevasti, joten hän oli varmasti tyytyväinen tulokseen.

Gylling alusti myös kysymyksen maanvuokraajille maksettavasta korvauksesta, jos heidät häädetään ennen vuokralain uudistamista. Uhkana oli se, että vuokraolojen parantaminen aiheuttaisi häätöjä ennen uuden lain astumista voimaan. Gylling totesi, että jos maanvuokraus kannattaisi huonosti, häädöt voisivat olla perusteltuja. Kuitenkin sekä ulkomainen että suomalainen kokemus viittasivat hänen mukaansa siihen, että suurviljelys kannatti yleensä huonommin kuin pienviljelys. Maanvuokralakiin olisi saatava häätökielto, joka kuitenkin mahdollistaisi taloudellisen

275 Torpparien ensimmäisen yleisen edustajakokouksen ptk., Helsinki 1906, s.44-47; Rasila 1961. s.314-318; Soikkanen 1961, s.287. Viljo Rasila on myöhemmin arvioinut jopa, että torpparit halusivat omistaa tilansa, mutta tämä kanta vaiennettiin tässä kokouksessa. Ainakin kokouksen osallistujien osalta tämä näkemys vaikuttaa liioittelulta, vaikka omistusoikeuden kannattajiakin kokouksessa ilman muuta oli. Vrt. Rasila, Viljo, Agraarikysymys Suomessa 1800-luvun lopulla ja 1900-luvun alussa. Historiallinen arkisto 87. Helsinki 1986, s.81.

276 Torpparien ensimmäisen yleisen edustajakokouksen ptk., Helsinki 1906, s.44-49. 
edistyksen. Jos kuitenkin maanvuokraaja häädetään, hänen olisi saatava tekemistään raivaustöistä korvaus. ${ }^{277}$

Korvauskysymyksessä kokouksen vaatimukset tiivistyivät kahdeksi ponneksi: "häädettäessä on korvattava maanvuokraajalle raivaamisesta ja rakentamisesta aiheutuneet kustannukset" sekä "vuokramiesten on pyrittävä järjestäytymällä estämään häädöt". Kokous valitsi aikarajaksi, jonka jälkeen häädetyillä pitäisi olla oikeus korvaukseen, edellisen maanvuokralain voimaantulopäivän 1.1.1904..$^{278}$

Gylling alusti myös kysymyksen, miten uudisviljelystä valtion ja yksityisten mailla olisi edistettävä. Tämä olisi tarpeen maanvuokralain uudistamisen jälkeen, koska paremmat vuokraolot tekisivät maanomistajat haluttomammiksi luovuttamaan maata uusien vuokratilojen perustamiseen. Tämä koskisi erityisesti tukki- ja tehdasyhtiöitä. Gyllingin mukaan maanvuokraajien uudisasutus olisi yhteiskunnalle edullista, koska se ei vaadi suuria pääomia ja hyvillä ehdoilla pyrkijöitä olisi runsaasti. Tämä tosin vaati pakkotoimenpiteitä, jotka oli kuitenkin suunnattu nykyistä mielivaltaa vastaan. Kokous kannatti jälleen yleistä viljelyspakkoa. Lisäksi korostettiin, että valtion olisi edistettävä uudisasutusta. ${ }^{279}$

Pohjanmaan edustajien mielipiteet erosivat muutamassa kysymyksessä muiden mielipiteistä. He vaativat, että maanvuokraajista olisi tehtävä tilojensa omistajia ja ettei yksityistä omistusoikeutta loukattaisi missään muodossa. ${ }^{280}$ Kokouksessa olleet puolueen toimihenkilöt olivat monessa kohdin maltillisempia kuin maanvuokraajien edustajat, joista monet esimerkiksi vaativat häätöjen kieltämistä kokonaan. Kokouksen johdon tehtäväksi jäi näissä kohdin vuokramiesten radikaalimpien vaatimusten torjuminen. Päätökset seurasivat lopulta varsin pitkälle SDP:n johdon linjauk-

277 Torpparien ensimmäisen yleisen edustajakokouksen ptk., Helsinki 1906, s.72-74.

278 Torpparien ensimmäisen yleisen edustajakokouksen ptk., Helsinki 1906, s.74-76.

279 Torpparien ensimmäisen yleisen edustajakokouksen ptk., Helsinki 1906, s.76-78.

280 Gylling 1906 G, s.191. 
sia. ${ }^{281}$ Ensimmäisen maanvuokraajien edustajakokouksen suurin merkitys olikin maanvuokraajien enemmistön liittäminen sosialidemokraattien linjoille. Tämä oli merkittävä tekijä vuoden 1907 vaalimenestyksessä.

Gylling ilmaisi tyytyväisyytensä maanvuokraajien järjestäytymiseen ja liikkeen saamaan suuntaan. Hän totesi, että maanvuokraajat olivat luopuneet vaatimasta omaa maata, mikä olisikin ollut käytännössä mahdotonta toteuttaa. Tampereen kokouksessa tilalle oli tullut viljelypakkovaatimus, joka olisi hyvä ratkaisu myös tilattoman väestön kannalta. Gylling huomautti kuitenkin, että varsinaisten maatyöläisten edut yhtyivät selvemmin työväenliikkeen yleisiin pyrkimyksiin kuin maanvuokraajien, jotka olivat samalla kertaa myös pienviljelijöitä. ${ }^{282}$

Porvarilliset piirit olivat puolestaan tyytymättömiä maanvuokraajien liikkeen suuntaan. Vanhasuomalaisten katkeruutta lisäsi, että aloite maanvuokraajien yleisen kokouksen järjestämisestä oli lähtöisin puolueen Uusimaa -lehdestä, mutta sosialidemokraatit olivat onnistuneet saamaan liikkeen johdon käsiinsä. ${ }^{283}$

SDP:n puoluekokous järjestettiin Oulussa 20.8.-27.8.1906 eli reilut neljä kuukautta ensimmäisen torpparien edustajakokouksen jälkeen. Gylling ei osallistunut tähän kokoukseen, mutta monet muut suurlakon murroksessa puolueeseen liittyneet akateemiset nuoret henkilöt olivat vahvasti esillä. Kokouksessa hyväksyttiin vaaliohjelma vuoden 1907 valtiopäivävaaleihin ja varsinkin maatalousosaa uudistettiin radikaalisti. Tampereen torpparikokouksen jälkeen voitiin todeta tyytyväisenä, että maanvuokraajien liike oli puolueen käsissä ja oli hyväksynyt sen sosialistiset linjaukset. Gyllingin olleessa poissa kysymyksestä alusti Väinö Wuolijoki.

\section{Soikkanen 1961, s.288.}

282 Gylling, Edvard, Maalaistyöväki ja sosialismi Suomessa. Työmies 27.2.1907 (C); Viljo Rasilan mukaan torpparit sijoittuivat vuosisadan alun yhteiskunnassa kutakuinkin sosiaalisen hierarkian keskikohdalle. Lampuodit olivat torpparien ylempänä ja mäkitupalaiset hieman alempana tässä hierarkiassa. Rasila 1995, s.307, 309. Tässä valossa Gyllingin arvio maanvuokraajien asemasta oli melko oikea.

283 Eskola, Seikko, Sosiaalipolitiikka Suomalaisen Puolueen ohjelmassa vuonna 1906. Studia Historica Jyväskyläensiä I. Jyväskylä 1962, s.409. 
Hän myönsi, että Forssan ohjelma oli maatalouden osalta ristiriitainen, koska periaatteellisessa osassa katsottiin suurviljelyksen vahvistuvan mutta maatalousohjelmassa tuettiin pienviljelystä. Hän totesi toisaalta, että sosialismin teoreetikot olivat epävarmoja pienviljelyksen kannattavuutta koskevassa asiassa, eivätkä tutkimustuloksetkaan olleet yksiselitteisiä. Tästä johtuen hän kannatti asettumista odottavalle kannalle. Wuolijoki asettui kuitenkin voimakkaasti kannattamaan viljelyspakkoa ja uuden maanvuokralain säätämistä. Kokousedustajat hyväksyivätkin nämä vaatimukset. Näin kokous asettui käytännössä samoille linjoille kuin Tampereen torpparikokouskin. ${ }^{284}$

Kaiken kaikkiaan SDP:n ja maanvuokraliikkeen keskeiset maatalouspoliittiset tavoitteet muodostuivat samanlaisiksi. Tärkeimmät tavoitteet olivat uusi maanvuokralaki ja viljelyspakko. Näitä asioita ajaessaan Gylling yhdisti menestyksellisesti tutkijan ja poliitikon roolinsa. On kuitenkin huomattava, ettei viljelyspakkovaatimus ollut sosialistinen linjaukseksi, sillä toteutuessaan se olisi merkinnyt pienviljelyksen vahvistumista. Sisällissodan jälkeen K. H. Wiik nostikin viljelyspakon esimerkiksi siitä, kuinka puolue ajoittain horjui pois marxilaiselta linjalta. ${ }^{285}$ Tämän tosin myös Gylling ja tiesi ja tunnusti maanvuokraajakokouksen aikoihin todetessaan, että se oli väliaikainen "porvarillinen" ratkaisu. ${ }^{286}$

Gylling oli tyytyväinen maanvuokraajien järjestäytymiseen, koska se auttoi maanvuokraolojen uudistamisessa. Hänen mukaansa vuokralakien parannus ei kuitenkaan yksistään riittänyt, koska maanomistajat voisivat häätää maanvuokraajia ennen lakien astumista voimaan. Gyllingin mielestä yhteiskunnalla oli kolme syytä estää häädöt: jokaisen maanvuokraajan suojaaminen inhimilliseltä kannalta katsottuna, tilattoman väestön kysymyk-

284 Suomen sosialidemokraattisen puolueen viidennen edustajakokouksen pöytäkirja. Ei painopaikkaa ja -vuotta. (SDP:n V PK) s.7-8, 304-316, 435444.

285 Wiik, Karl H., Kovan kokemuksen opetuksia. Sananen Suomen työväelle. 3. painos. Helsinki, s.12-13.

286 Gylling, Edvard, Viljelyspakko ja tilattoman väestön asema. SosA 17 $18 / 1906(\mathrm{H})$, s.517-518. 
sen kärjistymisen ehkäiseminen ja maan tehottoman käytön estäminen. ${ }^{287}$ Gyllingin perusteluissa yhdistyi humanismi, pyrkimys sosiaalisen oikeudenmukaisuuteen ja yhteiskunnan taloudellinen tehokkuus. Sosialistinen teoria yhteiskuntakehityksestä oli rinnakkain sosiaalipoliittisen intressin kanssa.

Gyllingin mukaan vuokralakiin olisi saatava häätökielto, joka estäisi taloudellisesti epäoikeutetut häädöt ja varjelisi maanvuokraajien oikeuksia, mutta samalla mahdollistaisi taloudellisen edistyksen. Hän ehdotti, että talollisen tulee maksaa häätämälleen maanvuokraajalle korvaus, joka on yhtä suuri kuin vuokratilan tuotantoarvo. Tällaisen lain ensisijainen tarkoitus olisi häätöjen estäminen ennen kuin uusi maanvuokralaki astuisi voimaan. ${ }^{288}$

Suomessa oli useita maanvuokraajalakkoja, joista kuuluisimmaksi muodostui Laukon lakko. Laukon tilan omistajan ja torpparien väliset suhteet olivat kärjistyneet, mistä seurauksena oli ollut toukokuussa 1907 torpparien lakko. Heidät häädettiin tammikuussa 1907, minkä lisäksi seuraavana keväänä ja kesänä häädettiin Laukon ja Tottijärven kartanoiden alueelta kymmeniä torppareita. ${ }^{289}$ Laukon tapahtumia käsiteltiin maatalousvaliokunnassa vuoden 1907 valtiopäivillä, joissa sosialidemokraateista erityisesti Sulo Wuolijoki asettui voimakkain sanoin torpparien puolelle. Porvarienemmistöinen maatalousvaliokunta katsoi, että epäkohdista huolimatta lakko oli liian radikaali toimenpide. Maatalousvaliokunta syytti tapahtuneesta sosialidemokraattien kiihotusta Tampereen kokouksessa, missä oli rohkaistu lujaan

287 Gylling 1906 F, s.154-155.

288 Gylling 1906 F, s.155-157.

289 Rasila, Viljo, Torpparikysymyksen ratkaisuvaihe. Suomen torpparikysymys vuosina 1909-1918. Helsinki 1970, s.38-40. Tottijärven kunta anoi tapausten johdosta, että kartanot lunastettaisiin valtion haltuun, mutta ehdotus ei johtanut mihinkään toimenpiteisiin. 24 häädettyä valitti Turun hovioikeuteen, joka 13.3. 1909 vahvisti kihlakunnanoikeuden antaman häätötuomion. Mikäli uusi maanvuokra-asetus olisi ehtinyt astua voimaan ennen päätöstä, häädöt olisi peruutettu. Häädetyt valittivat kuitenkin vielä uudelleen hovioikeuteen ja prokuraattori Aleksei Hosianoville, mutta mikään ei johtanut häätöjen peruuttamiseen. 
järjestäytymiseen, mikä heidän tulkintansa mukaan merkitsi lakkoilua. ${ }^{290}$

Kirjoituksia maatalouden kysymyksistä

Gylling kirjoitti vuonna 1906 artikkelin Pohjois-Amerikkaan suuntautuvasta siirtolaisuudesta. Suomessa oli etsitty syytä vuodesta 1899 lähtien kasvaneelle siirtolaisuudelle kärjistyneistä valtiollisista tapahtumista eli venäläistämispolitiikasta. Gylling kiisti tämän toteamalla, että monissa vakaammissa maissa kehitys oli mennyt samaan suuntaan. Hän katsoi eurooppalaisen siirtolaisuuden Pohjois-Amerikkaan johtuvan ensisijaisesti siellä vallitsevista paremmista taloudellisista oloista. Niin Suomesta kuin muuallakin lähtevät siirtolaiset olivat etupäässä varattomia kansalaisia. Suomessa siirtolaisuus keskittyi ensin Pohjanmaalle, mistä se levisi pohjoiseen Satakuntaan, Keski-Suomeen ja Ahvenanmaalle. Siirtolaisuus näiden alueiden ulkopuolelta oli hänen mukaansa varsin vähäistä..291

Tilastollisella analyysillä Gylling osoitti sen, että varsinaisten tilallisten osuus siirtolaisista oli varsin vähäinen, toisin kuin oli luultu. Suurin osa siirtolaisista oli tilallisten ja torpparien lapsia sekä loisia ja mäkitupalaisia. Jälkimmäiset ryhmät olivat tilatonta väestöä ja edellisistä suurin osa olisi sellaiseksi muuttunut, koska kotitalo tai torppa annettiin yleensä vain yhdelle lapsista. ${ }^{292}$

Gylling yhdisti siirtolaisuuden maaseudun tilattoman väestön lisääntymiseen ja taloudelliseen ahdinkoon. Selittävinä tekijöinä

290 Valtiopäivät (VP) 1907, Asiakirjat V, s.13-18; vrt. myös Sivula, Sinikka, Sulo Wuolijoki. Teoksessa Tiennäyttäjät 3. Suomalaisen työväenliikkeen merkkimiehiä Ursinista Tanneriin. Toim. Soikkanen, Hannu. Rauma 1968, s. 60-61.

291 Gylling, Edvard, Siirtolaisuutemme ja tilaton väestö, SosA, näytenumero 3/1906 (C), s.32-39.

292 Gylling 1906 C, s.38-39. Väärä arvio perustui virallisen tilaston julkaisemiin tietoihin vuosilta 1900-1902. Niissä oli kuitenkin tilalliseksi luettu myös lampuodit, entiset talolliset, torpparit sekä talollisten ja torpparien lapset. 
olivat ensisijaisesti taloudelliset syyt, mutta myös mentaalisilla tekijöillä oli merkitystä. Siirtolaisuus ei puhjennut ensiksi niissä osissa maata, joissa tilattomia on eniten, vaan Pohjanmaalla. Gyllingin mukaan syynä tähän oli etupäässä pohjanmaalaisten kansanluonne. Toisaalta hän korosti sitä, että Suomessa olisi runsaasti toimeentulomahdollisuuksia, jos yhteiskunnalliset epäkohdat korjattaisiin. Kapitalistinen tuotantotapa kuitenkin riisti tilattomilta mahdollisuuden maanviljelyyn. Tästä syystä kapitalismi muodosti hänen mukaansa uhan koko kansallisuudelle, joten siirtolaisuuden ehkäisemiseen riittäisi vain järjestelmänmuutos. ${ }^{293}$ Perusteena sosialismiin siirtymiselle oli siis myös varsin nationalistissävytteinen ajatus kansallisuuden säilymisen tärkeydestä. Ajatus taloudellisista tekijöistä siirtolaisuuden syynä ei Suomessakaan ollut uusi. Siihen oli kiinnittänyt huomiota August Hjelt vuotta aiemmin ilmestyneessä artikkelissaan, missä korostettiin suhdannevaihteluiden merkitystä. ${ }^{294}$

Gylling seurasi myös kansainvälistä keskustelua maatalouspolitiikasta. Yhdysvaltalaisen Henry Georgen (1862-1916) mukaan yhteiskunnan taloudellisesti edistyessä köyhyys lisääntyi eräissä väestökerroksissa, koska maanomistajat hyötyivät hyvissä paikoissa sijaitsevasta maasta saaden maakorkoa. Hän esitti, että mainittu maankorko otettaisiin verottamalla valtion haltuun, jotta varallisuuserot tasaantuisivat. ${ }^{295}$ Gylling otti kielteisen kannan Georgen ratkaisumalliin, koska tällainen verotus olisi mutkikasta ja aiheuttaisi liian äkillisiä taloudellisia muutoksia. Gylling katsoi, että sellaiset maatalousongelman ratkaisukeinot, "jotka eivät lainkaan uskalla koskea ja rajoittaa yksityisen pyhää lunastusoikeutta maahansa”, ovat mahdottomia. Paras ratkaisu olisi se, että yhteiskunta ottaisi maan haltuunsa, mitä George kannattajineen ei hyväksynyt. Vaatimus oli kuitenkin toistaiseksi epärealistinen, joten toteuttamiskelpoisin vaihtoehto oli viljelyspakko. Se koskisi vain maanomistajia, joilla oli viljelyskelpoista maata, kun taas

293 Gylling 1906 C, s.39.

294 Pitkänen 1988, s.157.

295 George, Henry, Edistys ja köyhyys. Suom. Järnefelt, Arvid. Helsinki 1906(1879), s.3-6, 401-414. 
veroa nostettaisiin sellaisestakin maasta, jota kukaan ei haluaisi viljellä. ${ }^{296}$ Gylling teki tässä selvän pesäeron Georgen marxilaisista poikkeaviin näkemyksiin, mutta oli kuitenkin edelleen halukas perehtymään monenlaisiin maatalouspoliittisiin ajatuksiin.

Gylling vastusti myös yleistä pakkoluovutusta, koska se voisi saada aikaan taloudellisesti huonoja vaikutuksia kuten maakoron verotuskin. Hän kannatti kuitenkin joissakin tapauksissa sovellettavaa suppeampaa pakkoluovutusta. Tämäkin kohtasi kuitenkin porvarillisissa puolueissa enemmän vastustusta kuin viljelyspakko, joka olisi helpompi toteuttaa. Gylling myönsi, että viljelyspakko oli porvarillinen ehdotus, koska sen toteuttaminen edistäisi maan vuokrausta ja laillistaisi tämän "vanhan riistomuodon". Kaikki uudistukset oli kuitenkin rakennettava porvarillisissa puitteissa, kunnes kehitys johtaisi täydelliseen muutokseen. Pääasia oli, että uudistukset sopisivat luokkataistelun puitteisiin ja mahdollistivat taloudellisen edistyksen, päätteli Gylling. ${ }^{297}$

Gyllingin mukaan kaikki maanvuokraajaryhmät muodostivat kokonaisuuden, koska heidän toimeentulonsa oli riippuvainen vuokratusta maapalasta. Maanvuokraajat eivät uskaltaneet viljellä täydellä teholla maataan, koska he voisivat koska tahansa menettää työnsä tulokset. Tästä huonosta maankäytöstä kärsi koko yhteiskunta. ${ }^{298}$ Gylling määritteli tilattoman väestön eri tavoin kuin sen oloja tutkinut agraarikomitea. Hänen mielestään tilattomaan väestöön eivät kuuluneet lampuodit ja ne torpparit, joilla on maata yli 3-4 hehtaaria, koska he eivät tarvinneet niinkään lisämaata kuin vuokraehtojensa parantamista. Myöskään teollisuustyöväestö ei hänen mukaansa kuulunut varsinaiseen tilattomaan väestöön. ${ }^{299}$

Viljelyspakon alaiseksi piti Gyllingin mielestä määrätä viljelyskelpoiset valtion ja yksityisten omistamat maat. Ensimmäiseksi tulivat kyseeseen suot, koska niiden viljelykseen otto oli helpointa

296 Gylling 1906 H, s.514-516.

297 Gylling 1906 H, s.517-518.

298 Gylling 1906 D, s.84-85.

299 Gylling, Edvard, Uutta maalaisolojamme valaisevaa tilastoa, SosA 30/1907 (F), s.173. 
ja ne tuottivat vähiten. Seuraavaksi viljelyspakko olisi ulotettava kaikkeen viljelyskelpoiseen kuivaan maahan ja sen jälkeen kaikkeen viljelyksessä olevaan maahan, jos omistaja jätti sen metsittymään. 25 hehtaarin rajaan saakka maata saisivat kaikki tilattomat, sekä ne torpparit, mäkitupalaiset, palstatilalliset ynnä muut, joiden viljelysmaa oli tätä pienempi. Viljelyspakosta hyötyisivät siis myös lähes kaikki maanvuokraajat ja pientilalliset. ${ }^{300}$

Gylling vetosi historiaan todetessaan, että Suomessa oli ennenkin käytetty pakkokeinoja edistettäessä uudisviljelystä. Muidenkin yhteiskunnallisten ilmiöiden tapaan omistusoikeus oli historiallisen kehityksen luoma. Se rajoitti kuitenkin omistamattomia käyttämästä tuotantovälineitä. Liikaväestön olojen turvaamiseksi olisi siirryttävä tehokkaampiin tuotantotapoihin, mutta vanhentuneet omistusolot estivät kehityksen. ${ }^{301}$ Gylling tukeutui tässä Marxin käsitykseen, että vallankumouksen taustalla oli tuotantovoimien ja tuotantosuhteiden ristiriidan kärjistyminen. ${ }^{302}$ Gylling totesi, että aina ennenkin Suomen historiassa vanhat omistajat olivat vastustaneet pakkoluovutuksia ja viljelyspakkoa voimakkaasti. Nämä ankaratkin toimenpiteet olivat kuitenkin olleet oikeita, koska väestönkasvu voimistui ja yhteiskunta edistyi. Näin kävi esimerkiksi, kun siirryttiin kaskenpoltosta voimakkaampaan maan muokkaamiseen. ${ }^{303}$

300 Gylling 1906 H, s.518-520.

301 Gylling, Edvard, Pakkoluovutuksen ja viljelyspakon entinen ja nykyinen asema meillä. SosA 26/1907 (D), s.63.

302 Ks. esim. Marx, Karl - Engels, Friedrich, Feuerbach. Materialistisen ja idealistisen katsantokannan vastakkaisuus (kirjoitettu 1845-46).Teoksessa Marx, Karl - Engels, Friedrich, Valitut teokset 1. Moskova 1970, s.52-60; Nämä ns. Feuerbach-teesit aloittivat Marxin ajattelussa kauden, jolloin historiallinen materialismi kehittyy ja luokkataistelusta tulee historian moottori. Samalla tuotantosuhteiden ja tuotantovoimien merkitys rakenteellisina tekijöinä korostuu. Schanz 1996, s.92, 113-116.

303 Gylling 1907 D, s.64-66. Gylling mainitsi tässä yhteydessä mm. 1300- ja 1400-luvulta olevia kuninkaallisia määräyksiä, joissa todettiin, että kuka tahansa sai ottaa maat viljelykseen, jos omistaja eivät tahtoneet tai kyenneet tähän. Vuonna 1741 astui puolestaan voimaan viljelyspakkolaki, jota vielä jyrkennettiin vuonna 1770 . 
Gyllingin mielestä tilattoman väestön kasvun takia uudisviljelystä olisi edistettävä. Porvarillisten puolueiden taholta oli ehdotettu, että valtion pitäisi ostaa maita ja jakaa niitä tilattomille. Gyllingin mukaan valtion varat eivät riittäisi tähän, mutta ehdotuksen motiivina olikin lähinnä omistajien määrän lisääminen, jotta yhteiskunta yleisen ja yhtäläisen äänioikeuden toteutumisen jälkeenkin pysyisi porvarillisella pohjalla. ${ }^{304} \mathrm{Hän}$ katsoi, että SDP oli ainoa puolue, joka ajoi erityisesti maalaisköyhälistön asiaa. Puolueen lyhyen aikavälin vaatimuksena oli, että omistusoikeutta maahan supistettaisiin viljelyspakon avulla, jonka mahdollistaman uudisraivauksen kautta tilattomien mahdollisuus toimeentuloon paranisi. Pitkällä aikavälillä puolue kannatti tuotantovälineiden ja maan pakkoluovutusta valtiolle, koska yksityinen omistusoikeus oli aina ollut syy ristiriitoihin ja kurjuuteen. Gyllingin mielestä nämä olivat ainoat tehokkaat ja historian valossa oikeutetut keinot tilattomien avustamiseksi. ${ }^{305}$

Kehityksen historiallinen tausta oli Gyllingin kirjoituksissa usein vahvasti esillä. Gylling tuki yleensä väitteitään vahvalla tilastollisella aineistolla. Vuonna 1850 Suomi oli ollut vielä omavarainen maa, jonka ulkomaankauppa oli varsin vähäistä. Väkiluku oli hieman yli puolitoista miljoonaa, kulkuvälineet olivat huonot ja tuotanto oli melkein yksinomaan pientä kotitarvetuotantoa. 1800-luvun puolivälin jälkeen laajojen metsien arvo kohosi ja metsäteollisuudesta tuli Suomen ensimmäinen kapitalistinen tuotantohaara, jossa tuotantoa harjoitettiin voiton saamiseksi. Vähitellen kapitalistinen vaihdantatalous laajeni. Seurauksena oli kulkuvälineiden kehittyminen, teollisuuden lisääntyminen ja maanviljelyksen aseman heikkeneminen. Maatalous oli kuitenkin edelleen selvä pääelinkeino, joskin sen sisällä pääpaino oli siirtynyt karjanhoitoon. Kaiken kaikkiaan Gyllingin mukaan Suomen talous oli siis vähitellen kehittynyt yhä kapitalistisemmaksi, mikä oli lisännyt myös ulkomaankauppaa. ${ }^{306}$

304 Gylling 1907 D, s.67.

305 Gylling 1907 D, s.67-68.

306 Gylling, Edvard, Katsauksia Suomen taloudelliseen kehitykseen. Työväen Kalenteri II (julkaistu 1909), 1908 (F), s.116-122. 
Gylling katsoi, että maanvuokraolojen uudistaminen ei yksinään riittänyt. Sen lisäksi oli välttämätöntä edistää maanvuokraajien uudisasutusta, koska maanomistajat olivat haluttomia luovuttamaan maitaan uusien vuokratilojen perustamiseksi. Tämä olisi yhteiskunnalle edullista, koska pyrkijöitä olisi paljon, eikä toimenpide vaatisi suuria pääomia ja laajaa virkamieskoneistoa. Paras tapa olisi yleisen viljelyspakon sä̈äminen. Gylling myönsi, että tämä olisi pakkovaltaa, mikä kuitenkin suuntautui yhteiskunnalle turmiollista mielivaltaa vastaan. ${ }^{307}$

Gyllingin usko tilastoihin ajankohtaisten ongelmien osoittamisessa ja ratkaisujen pohjana tuli esille kirjoituksessa lampuotitilojen, torppien ja mäkitupa-alueitten vuokramaksusta. Hän totesi, että maatalousolojen tilasto oli Suomessa huonolla pohjalla, mikä oli hallitseville luokille hyvä. Kun ei ollut tilastoja, ei myönnetty epäkohtien olemassaoloa. ${ }^{308}$ Olemassa olevien tilastojen puutteellisuus tuli poistaa, mitä Gylling perusteli seuraavasti: "Tilastollisten tietojen merkitys sekä epäkohtien paljastamisessa, agitatsionityössä että taloudellisen kehityksen kulun ja uudistusehdotusten määräämisessä on arvaamattoman suuri” ${ }^{309}$

Gylling analysoi myös porvarillisen ja sosialistisen lähtökohdan eroa. Hänen mukaansa hallitsevat luokat eivät tunnustaneet sitä, että eri luokilla oli vastakkaiset edut. Sosialistit tunnustivat tämän ja katsoivat, että kunkin luokan tuli itse ajaa etuaan. Gylling katsoi väestöryhmän luokka-aseman riippuvan sen etujen suhteesta vallitsevaan yhteiskuntajärjestelmään. Gyllingin mukaan syy maanvuokraajien ja tilattoman väestön huonoon asemaan oli rajoittamattomaan yksityiseen omistusoikeuteen perustuva maatalous, joten ne olivat sen luontevia vastustajia. ${ }^{310}$

307 Gylling 1906 F, s.157-158.

308 Gylling, Edvard, Hiukan lampuotitilojen, torppien ja mäkitupa-alueitten vuokramaksusta, SosA 40/1908 (C), s.108.

309 Gylling 1906 F, s.144.

310 Gylling, Edvard, Torpparit, tilattomat ja köyhälistöpuolue, SosA 42/1908 (D), s.174-177. 


\section{SDP:n maatalousohjelman puolustajana}

Eduskuntauudistus toi mukanaan organisoidut puolueet ja yksityiskohtaiset puolueohjelmat, joita laadittaessa täytyi pitää erityisesti silmällä suuresti kasvaneen äänestäjäkunnan toivomuksia. Torpparikysymys oli suurena yhteiskunnallisena kysymyksenä ollut jo tätä ennen esillä useiden puolueiden keskusteluissa ja ohjelmatyössä. Vuoden 1907 valtiopäivävaalien lähestyessä maatalouspoliittiset keskustelut nousivat kuitenkin yhä vahvemmin esille. ${ }^{311}$

Alkuvuodesta 1906 Lapualla järjestettiin vanhasuomalaisten ja nuorsuomalaisen välinen kokous, missä pohdittiin maaseudun ongelmien ratkaisukeinoja. Hannes Gebhard esitti kokouksessa itsenäisen maalaispuolueen perustamista ja hahmotteli sen ohjelmalliset suuntaviivat. Gebhard vetäytyi myöhemmin hankkeesta, mutta muiden toimesta perustettiin loppuvuodesta 1906 kaksikin maalaispuoluetta, Etelä-Pohjanmaalle paikallinen Nuorsuomalainen Maalaisliitto ja Oulussa valtakunnallinen Suomen Maalaisväestön Liitto. Ne yhdistyivät pian valtakunnalliseksi Maalaisliitoksi, joka pyrki vetoamaan ennen kaikkea itsenäiseen maanviljelijäväestöön. Sekä nuorsuomalaisten että vanhasuomalaisten piirissä suhtauduttiin kielteisesti uuden kilpailevan puolueen perustamiseen. ${ }^{312}$

Gebhard hylkäsi ajatuksen itsenäisestä maalaispuolueesta, mutta julkaisi alkuvuodesta 1906 oman maanvuokraohjelmansa, joka oli ensimmäinen ohjelma aiheesta. Siinä ehdotettiin jatkuvaa vuokraoikeutta, joka olisi minimissään 16 vuotta. Vuokran suuruuden määräisi ulkopuolinen vuokralautakunta. Maanvuokraaja voisi valita, maksoiko vuokran rahassa vai työssä. Maanvuokraaja saisi korvauksen maanomistajan luvalla tilaan tehdyistä parannuksista, vuokrasuhteen siirto-oikeuden sekä pakkolunastusmah-

311 vrt. Rasila 1961, s.335-342.

312 Borg 1965 A, s.75-79; Hakalehto, Ilkka, Maalaisliitto-Keskustapuolueen historia 1. Maalaisliitto autonomian aikana 1906-1917. Helsinki 1986, s.72, 97,153-169. 
dollisuuden, jos omistajat eivät viljelleet maata määräajan kuluessa eikä palstoittaminen turmellut emätilan viljelyksiä. ${ }^{313}$

Gebhardin ohjelma sisälsi joissain suhteessa jopa radikaalimpia vaatimuksia kuin SDP:n vuoden 1903 Forssan ohjelman maatalouden erillisohjelma. Gebhardin ohjelmassa lähestyttiin viljelyspakkoajatusta, mutta toisaalta hänen ohjelmansa ei ajanut valtion roolin kasvattamista samalla tavalla kuin sosialidemokraattien ohjelma. ${ }^{314}$ Vuoden 1906 vaaliohjelmassaan sosialidemokraatit hyväksyivät vaatimuksia, jotka olivat Gebhardin ajamia radikaalimpia. Kaiken kaikkiaan Gebhardin maataloutta koskevat näkemykset erosivat varsin vähän sosialidemokraattien linjauksista.

Vuonna 1906 valmistui sekä vanhasuomalaisten että nuorsuomalaisten uusi ohjelma. Molemmissa käsiteltiin maaseudun ongelmia, joskin vanhasuomalaisten ohjelma oli huomattavasti yksityiskohtaisempi kuin nuorsuomalaisten. ${ }^{315}$ Suomalaisen Puolueen sisällä vallitsi jännite siitä, oliko puolue enemmän suomalaiskansallinen puolue vai sosiaalinen reformipuolue. Puolueen vanhat konkarit painottivat yleensä suomalaiskansallisia linjauksia kun taas nuoremmat ajoivat voimakkaammin reformeja. Maatalousohjelmassa radikaalia linjaa ajoivat muun muassa puolueen ylioppilasyhdistys Suomalainen Nuija, työväenliikettä aiemmin kannattanut puoluesihteeri K. N. Rantakari (1896-1948) ja Hannes Gebhard. Suomalainen Puolue ei hyväksynyt Gebhardin ajamaa pakkolunastusperiaatetta, mutta muuten sen ohjelmasta tuli suhteellisen radikaali. ${ }^{316}$

Vanhasuomalaisten maatalousohjelma muistutti sosialidemokraattien ohjelmaa, koska ne molemmat perustuivat pohjimmiltaan syksyllä 1905 järjestettyjen torpparikokousten päätöslauselmiin. Suurimpana erona oli se, että vanhasuomalaisten pitkän aikavälin tavoitteena oli itsenäisen pienviljelijäluokan luominen. ${ }^{317}$

313 Rasila 1961, s.358-360; Alanen 1964, s.184.

314 Rasila 1961, s.260-262; Hakalehto 1986, s.72.

315 Rasila 1961, s347, 351.

316 Eskola 1962, s.404-405, 418, 432.

317 Eskola 1962, s.411-413; Leino-Kaukiainen, Pirkko, Suomalainen Puolue 1905-1918. Teoksessa Leino-Kaukiainen, Pirkko - Uino, Ari, Suomalais- 
Suomalainen Puolue ajoi maan hankkimista tilattomille seuraavin keinoin:

- valtion oli luovutettava viljelyskelpoisia kruununmaita tilattomille.

- valtion tulisi ostaa suurtiloja ja palstoittaa ne tilattomille.

- kuntien piti saamillaan valtiolainoilla ostaa ja palstoittaa tiloja tilattomille sekä välittää tilattomille lainoja maanhankkimista varten.

- valtion tuli antaa lainoja osuuskunnille, jotka hankkivat maata jäsenilleen.

Vanhasuomalaiset ajoivat myös uutta maanvuokralakia, jonka pääkohtia olivat vuokralautakuntien perustaminen, 50 vuoden vähimmäisaika vuokrasopimuksille ja maanvuokraajien oikeuksien lisääminen. ${ }^{318}$

Nuorsuomalaisen Puolueen maatalousohjelma oli huomattavasti ylimalkaisempi kuin vanhasuomalaisten. Siinä esitettiin maan hankkimista tilattomille uudisasuttamalla valtion omistamat viljelemättömät maat ja avustamalla tilattomia lainoilla lunastamaan maata. Maanvuokraajien asemaa oli parannettava lainsäädännön kautta, mutta pitkällä tähtäimellä oli pyrittävä tekemään heistä tilojensa omistajia. ${ }^{319}$

Suomeen oli lisäksi syntynyt kaksi maalaispuoluetta, joilla kummallakin oli oma ohjelmansa. Molemmat ohjelmat olivat saaneet vaikutteita Gebhardin ajattelusta, nuorsuomalaisten ohjelmasta sekä jossain määrin myös vanhasuomalaisilta ja sosialidemokraateilta. Ohjelmissa ajettiin tilattoman väestön maantarpeen ratkaisemista valtion maanluovutuksilla ja myöntämällä lainoja, maanvuokralain uudistamista sekä maanvuokraajien muuttamista maanviljelijöiksi. Ruotsalaisen Kansanpuoleen ohjelmassa vii-

kansallinen Kokoomus. Suomalaisen Puolueen ja Kansallisen Kokoomuspuolueen historia vuoteen 1929. Vammala 1994, s.85.

318 Suomalaisen Puolueen maalaisohjelma on painettuna Borg 1965 A, s.43-47.

319 KA, Nuorsuomalaisen Puolueen arkisto, puoluekokouksen ptk. 6-7.4.1906; Nuorsuomalaisten maalaisohjelma on painettuna Borg 1965 A, s.57-58. 
tattiin ylimalkaisesti maanomistamisen lisäämiseen maaseudulla ja vuokralainsäädännön uudistamiseen. ${ }^{320}$

Gylling otti kantaa porvarillisten puolueiden keinoihin ratkaista tilattoman väestön kysymys. Hänen mukaansa mahdollisuus uudisviljelyyn valtion mailla oli vähäistä, joten ehdotukset valtion lainoista ja lisämaiden lunastamisesta olivat merkittävämpiä. Valtiolla ei kuitenkaan ollut läheskään riittävästi varoja tarpeeksi laajaan tilattomien tukemiseen. Lisäksi menettely voisi nostaa maan arvoa keinotekoisesti, jolloin keinottelijat hyötyisivät. Gylling vetosi tässä Venäjän ja Saksan kokemuksiin. ${ }^{321}$

Gylling katsoi, että oli epärealistista kannattaa valtion tukipolitiikkaa ja vaatia samaan aikaan valtiolta runsaasti varoja kysyviä toimenpiteitä, kuten uudisasutuksen tukemista lainoilla, valtion maiden uudisasutuksen harjoittamista, työväenvakuutuksen järjestämistä ja koulupakkoa. Jotkut jopa vaativat kiivaasti vuokratilojen lunastamista yksityisiksi tiloiksi, mikä tarkoittaisi satojen miljoonien markkojen kustannuksia. Gylling huomautti myös, että lunastuspolitiikkaa kannattavat "säätypuolueet" vastustivat vielä vuoden 1897 valtiopäivillä samansuuntaista politiikkaa. ${ }^{322}$

Vuoden 1907 vaalien lähestyessä alkoi vaalitaistelu, jonka aikana puolueiden edustajien välinen sananvaihto koveni, ainakin lehtien palstoilla. Gylling puolusti vahvasti sosialidemokraattien maatalousohjelmaa, erityisesti edellisenä vuonna hyväksyttyä viljelyspakon vaatimusta.

Vanhasuomalainen professori J. R. Danielson-Kalmari arvosteli Uudessa Suomettaressa useaan otteeseen suomalaista sosialidemokratiaa. ${ }^{323}$ Danielson-Kalmari arvosteli kirjoituksessaan Edistyksen jarruttaminen lyhyesti sosialidemokraatteja kielteisestä

320 Ruotsalaisen Kansanpuolueen ja Maalaisliiton maatalousohjelmat ovat painettuna Borg 1965 A, s.69,82-83,102-103.

321 Gylling 1906 H, s.400-404.

322 Gylling 1906 H, s.404.

323 "Sosialistien viljelyspakko"-artikkelisarja. Se oli kirjoitettu nimettömänä, mutta Danielson-Kalmari totesi myöhemmin olleensa niiden kirjoittaja, kuten Wuolijoki oli arvannut. Ks. Danielson-Kalmari, J. R., Herra Sulo Wuolijoki yrittää vielä kerran. Uusi Suometar 12.3.1907 (D). 
asenteesta uskontoa ja kirkkoa vastaan sekä vaatimuksesta maan pakkoluovutuksen toteuttamiseen. ${ }^{324}$ Hän totesi kirjoituksessaan Meikäläinen sosialidemokratia, että suomalaiset sosialistit olivat omaksuneet saksalaisilta jyrkän luokkataistelulinjan, missä pyrittiin alempien kansankerrosten kiihottamiseen luokkavihaan. $\mathrm{He}$ eivät kannattaneet todellisia uudistuksia, vaan yhteiskuntaluokkien välisten erojen suurentamista, mikä johtaisi vallankumoukseen. Danielson-Kalmarin mielestä Oulun puoluekokouksessa asetetut vaatimukset olivat lähinnä propagandistisia ja taktisia. Erityisen huonoja olivat ajatukset maan pakkoluovutuksesta ja vuokraviljelijän häätökiellosta, vaikka tämä olisi syyllistynyt pahoihin laiminlyönteihin. Käsittämätön oli myös ajatus, että alin verotettava tulo olisi kaupungissa paljon korkeampi kuin maaseudulla. SDP oli kirjoituksen mukaan lisäksi unohtanut täysin kieliasian, vaikka J. V. Snellmanin ja Yrjö Koskisen toiminta oli parantanut köyhien asemaa. ${ }^{325}$

Danielson-Kalmari totesi kirjoituksensa toisessa osassa, että sosialistit syyllistyivät valehteluun väittäessään Suomalaisen Puolueen olevan vastuussa vuoden 1900 maanvuokralaista. Myös syytökset vanhasuomalaisten kyltymättömästä vallanhalusta olivat vääriä. ${ }^{326}$ Hän puolestaan katsoi, etteivät suomalaiset sosialistit olleet tarpeeksi kyvykkäitä käyttämään valtaa. ${ }^{327}$ Tässä toteamuksessa tulee esiin meritokraattisten vanhasuomalaisten pyrkimys korostaa demokratian rinnalla kokeneiden edustajiensa "kyvykkyyden" merkitystä; määrän lisäksi oli muistettava myös laatu. ${ }^{328}$

Gylling asettui Danielson-Kalmarin päävastustajaksi ja joutui sitä kautta tarkentamaan omia näkemyksiään ja argumenttejaan

324 Danielson-Kalmari, J. R., Edistyksen jarruttaminen. Uusi Suometar 25.11. 1906 (A).

325 Danielson-Kalmari, J. R., Meikäläinen sosialidemokratia I, Uusi Suometar 2.12.1906 (B).

326 Danielson-Kalmari, J. R., Meikäläinen sosialidemokratia II. Uusi Suometar 4.12.1906 (C).

327 Danielson-Kalmari, J. R., Meikäläinen sosialidemokratia II, jatko-osa. Uusi Suometar 6.12.1906 (D).

328 Vares 1996, s.53-54. 
sosialidemokraateille vaikeassa maatalouspolitiikassa. Gylling vastasi Sosialistisessa Aikakauslehdessä seuraavasti:

että luokkataistelua ja luokkatietoisuutta on herätettävä, sehän on edellytys, että joku kansanluokka ylipäätään voi olonsa ymmärtää ja niitä parantaa tarvitsematta uskoa ja luottaa vallassaolijain hyvään tahtoon ja enemmän tai vähemmän siveellisiin periaatteisiin. Se toisin sanoen on kaiken kansanvaltaisuuden vaatimus eikä siinä siis voi löytää mitään pahaa. ${ }^{329}$

Danielson-Kalmari ja Gylling ymmärtävät käsitteen "luokkataistelu" eri tavoin. Edellinen näki luokkataistelun väkivaltaisena vallankumouksellisuutena, kun taas jälkimmäinen liitti sen tietoisuutena oman luokan eduista. Taustalla on tietenkin myös erilainen tulkinta yhteiskunnan luonteesta. Gyllingin näkemys oli marxilainen, jonka mukaan kapitalistisessa yhteiskunnassa oli jyrkästi vastakkain kaksi luokkaa, kapitalistit ja työläiset. ${ }^{330}$ Niiden välille syntyi historiallisen automatiikan kautta luokkataistelutilanne, joka ei kuitenkaan välttämättä ollut väkivaltainen. Vanhasuomalaiselle Danielson-Kalmarille luokkien vastakkaisuutta korostava lähtökohta oli jo sinällään vieras.

Gyllingin mukaan sosialidemokraatit pyrkivät todellisiin parannuksiin työväen asemassa eikä vain vallankumoukseen. Hän katsoi, että toisenlainen johtopäätös perustui väärinkäsityksiin SDP:n ohjelman yksityiskohdista. Danielson-Kalmari ei huomioinut sitä, että Oulun puoluekokouksessa pakkoluovutus hyväksyttiin ainoastaan periaatteellisella tasolla, mutta vaatimus viljelyspakosta oli käytännössä tärkeämpi. Gylling myönsi, että maanvuokraajan häätämistä koskeva kohta oli epäselvä, mutta häätö on mahdollinen joissakin tapauksissa. Hän myönsi, että tuloveroajattelun yksityiskohdat voivat olla vanhentuneita, mutta periaate oli silti oikea. Oli oltava alin verotettava tulo, mikä vaihteli elinkustannusten mukaan maaseudun ja kaupunkien välillä.

329 Gylling, Edvard, Sosialidemokratia ja suomettarelaiset, SosA 20-21/1906 (I), s.460.

330 Marxin luokka-käsitteestä tarkemmin Walther 1990, s.267-269. 
Gyllingin mielestä SDP:n puolueohjelma oli kaiken kaikkiaan liian yksityiskohtainen, kun periaatteellisemmatkin kannanotot riittäisivät. ${ }^{331}$

Gylling myönsi, että sosialidemokraatit eivät välittäneet kielikysymyksestä, koska sosialismi internationalistisena aatteena antoi sekä ruotsin- että suomenkieliselle työväelle oikeuden kehittää omakielistä sivistystä. Hän tunnusti täysin J. V. Snellmanin ja osittain Yrjö Koskisenkin ansiot suomalaisuuden vapauttamisessa, muttei hyväksynyt siirtymistä ruotsinkielisten sortamiseen. Sosialidemokraatit yrittivät koota kansainväliseen taisteluun ne, joita yhdisti "yhteisen kärsimyksen, kapitalismin sorron siteet". 332

Vastauksessaan Danielson-Kalmari katsoi, että pakkoluovutusta voitiin jo nykyisen lainsäädännön perusteella käyttää erikoistapauksissa kun taas Gyllingin painottamalla viljelyspakolla oli pahat puutteensa. Danielson-Kalmarin mukaan vanhasuomalaisten halu parantaa maanvuokraajien asemaa oli aitoa, vaikka asia olikin jäänyt kielitaistelun ja venäläistämisen vastustamisen varjoon. ${ }^{333}$ Hän totesi, että vanhasuomalaiset katsoivat yhteiskunnallisen kokonaisuuden etua, mitä viljelyspakko ei edustanut. Oikeiston pelkästään maanomistajia suosiva asenne ja vasemmiston puhtaasti maanvuokraajia suosiva käsitys johtivat pelkästään hedelmättömään taisteluun. ${ }^{334}$ Danielson-Kalmari tarkoitti oikeistolla ainakin Ruotsalaista Kansanpuoluetta sekä mahdollisesti nuorsuomalaisia. Danielson-Kalmari myönsi Gyllingin olevan oikeassa siinä, että valtion varat eivät riitä lainojen myöntämiseen kaikille tilattomille. Hän katsoi kuitenkin, että ongelma voitaisiin ratkaista osittain sillä keinolla. Sitä paitsi hänen mukaansa viljelyspakko maksaisi lähes yhtä paljon valtiolle. ${ }^{335}$

331 Gylling 1906 I, s.460-462; vrt. Soikkanen 1975, s.101-102.

332 Gylling 1906 I, s.462-464.

333 Danielson-Kalmari, J. R., Sosialistiväittelyä. Uusi Suometar 29.12.1906 (E).

334 Danielson-Kalmari, J. R., Sosialistien viljelyspakko. Uusi Suometar 14.2. 1907 (A).

335 Danielson-Kalmari, J. R., Sosialistien viljelyspakko II. Uusi Suometar 16.2. 1907 (B). 
Gylling vastasi Danielson-Kalmarille Työmiehessä. Hän katsoi, että jos viljelypakkoa ei säädetä yhdessä uuden maanvuokralain kanssa, oli odotettavissa häätöjä. Vanhasuomalaiset luottivat ilmeisesti maanomistajien korkeaan moraaliin, koska eivät uskoneet laajamittaisiin häätöihin. Gyllingin mielestä tämä peruste oli riittämätön. Gyllingin mukaan viljelyspakko olisi vain väliaikainen toimenpide ennen vuokraolojen laajempaa uudistamista. Hän korosti, että sosialidemokraatit vaativat viljelyspakkoa ainoastaan maanvuokraajien edun takia, kuten vanhasuomalaistenkin pitäisi tehdä. Suomalainen Puolue katsoi, että valtion olisi avustettava lainoilla tilattomia maanhankintaan. Varojen puutteessa suurin osa ei kuitenkaan saisi näin maata. Vanhasuomalaisten mukaan hintaero maan lunastamisen ja viljelyspakon toteuttamisen välillä olisi pieni. Jos laskelmissa huomioidaan suuri raivaustyö, hintaero olisi Gyllingin mukaan korkea. ${ }^{336}$

Gylling myönsi, että valtio joutuisi käyttämään paljon varoja viljelyspakon toteuttamiseen mutta siinä tapauksessa rahat eivät menneet maanomistajien hyväksi. Danielson-Kalmari arvosteli sosialisteja siitä, etteivät he olleet ehdottaneet viljelyspakon yhteydessä metsän käyttöpakkoa. Gylling vastasi, että sosialidemokraatit ajoivat viime kädessä metsien ja maiden ottamista valtion haltuun. Viljelyspakko oli ennen kaikkea käytännöllinen vaatimus, kuten hän tässä korostaa:

Tilattoman väestön kysymykseen nähden ehdotetaan ensi sijasta viljelyspakkoa, vasta toisesta sijasta pakkoluovutusta, johtuu käytännöllisistä syistä. Sosialistit muodostavat kansan köyhimpien kerrosten puolueen ja ajavat niiden parasta, ja viljelyspakko on ainoa keino jolla nopeasti voidaan parannus saada tilattomien eduksi läpiajetuksi, pakkoluovutus on vaikeampi". 337

Danielson-Kalmari totesi vastauksessaan Gyllingille, että viljelyspakko olisi vaikea toteuttaa ja kallis ja siitä seuraisi "voittamat-

336 Gylling, Edvard, Suomettarelaiset vastustamassa viljelyspakkoa. Työmies 22.2.1907 (I).

337 Gylling 1907 I, tekstin harvennus on Gyllingin tekemä. 
tomia vaikeuksia, mielivaltaa ja vääryyttä”. Vaikeuksia tuottaisivat muun muassa seuraavat asiat: kunnan vuokralautakunnille tulisi liikaa työtä, monelta menisi mahdollisuus viljelysten laajentamiseen, metsät raiskattaisiin, viljelykset voitaisiin jättää heitteille sekä monissa paikoissa olisi paljon halukkaita, mutta vähän alueita tai päinvastoin. ${ }^{338}$

Danielson-Kalmarin mielestä viljelyspakko sortaisi köyhiä, joilla ei ollut varaa viljellä alueitaan, jolloin joku toinen saisi sen viljeltäväksi. Hän uskoi, että sosialistit perääntyivät viljelyspakkovaatimuksestaan, kuten oli jo käynyt pakkoluovutusvaatimuksen kanssa. Danielson-Kalmari katsoi, että Gylling kannatti pakkoluovutusta vain erityistapauksissa, minkä nykyinenkin laki salli. Hän totesi toisaalta, että ongelmana oli se, että melkein jokainen sosialidemokraatti selitti puolueen ohjelmaa omalla tavallaan. ${ }^{339}$ Danielson-Kalmari oli tässä asiassa ainakin osittain oikeassa. Maatalouskysymys oli sosialidemokraateille varsin ongelmallinen, eikä keinoista sen ratkaisemiseksi oltu yksimielisiä. Tosin Oulun kokouksen vaaliohjelma oli Forssan ohjelmaa yksiselitteisempi.

Gylling vastasi suivaantuneena: "Suomettaressa jatkaa sepustuksiaan nimetön kirjailija entiseen siivottomaan tapaansa". Hän myönsi, että viljelyspakon alainen viljelijä voisi raivata maan ja sen jälkeen jättää tilan. Hän kuitenkin uskoi, että omistautuminen maalleen oli kuitenkin todennäköisempää, koska viljelyspakon alainen maa nautti "sosialistisen vuokralain turvaa" eli runsaasti vapaavuosia ja pieniä veroja. Lisäksi tilaton olisi iloinen, kun työ vihdoinkin turvaisi elämän mahdollisuuden. ${ }^{340}$

Gylling korosti, ettei viljelyspakon toteuttamisesta seuraa täydellinen mielivalta ja sekasorto. Viljelyspakkoa vastaan ei ole asiallisia perusteluita, mutta vanhasuomalaiset katsoivat asioita enemmän tilallisten kuin tilattomien kannalta. Gylling katsoi, että vanhasuomalaisten tarkoitus oli lisätä vähitellen maanomistajien määrää, jotta uusi eduskunta pysyisi "terveellä pohjalla”. Tämä

338 Danielson-Kalmari, J. R., Sosialistien viljelyspakko III, Uusi Suometar 26.2.1907 (C).

339 Danielson-Kalmari, 1907 C.

340 Gylling 1907 I. 
pyrkimys vaikeutti omistusoikeutta rajoittavien ja tilattomien etujen mukaisten lakien laatimista. Hänen mukaansa tilattomien pitäisi muistaa, että "joka äänestää suomettarelaista ohjelmaa, pettää kanssaveljiensä asiaa" ${ }^{341}$

Vuonna 1908 Gylling ajoi edelleen viljelyspakkoa. Hän uskoi, että vanhasuomalaiset olivat Gebhardin johdolla muuttamassa kantaansa ja asettumassa viljelyspakon taakse. Gylling piti Gebhardia puolueen parhaana maatalousasiantuntijana, joka ei kuitenkaan vielä myöntänyt viljelyspakon välttämättömyyttä. Gebhard vaati sen sijaan, että valtion pitäisi auttaa tilattomia ostamalla heille maata. Gyllingin mielestä näin rikastutettaisiin lähinnä tilallisia, eikä ratkaisevasti autettaisi tilattomia. Gebhard myönsi, etteivät valtion varat riitä vuokratilojen ostamiseen, joten hänkin ajoi uutta maanvuokralakia. Gyllingin mielestä tämä kehitys osoitti, että köyhälistön voimakas yhteenliittyminen pakotti porvarit myöntymään heidän vaatimuksiinsa. ${ }^{342}$

Vuoden 1907 eduskuntavaalien alla Gyllingistä oli tullut sosialidemokraattisen puolueen maatalouspolitiikan johtava asiantuntija, ainakin teoreettisella ja käsitteellisellä tasolla. Gylling oli vaikuttanut vahvasti SDP:n maatalouspoliittisiin linjauksiin ja samalla siihen, että puolue oli saanut kasvavan torppariliikkeen johdon käsiinsä. Hän esiintyikin lehtien palstoilla ärhäkkänä sosialidemokraattien maatalouspolitiikan puolustajana. Edellä kuvattu debatti Suomalaista puoluetta edustavan professori DanielsonKalmarin kanssa on tästä hyvä esimerkki.

Gyllingin rooli oli suuri myös toisessa maanvuokraajien valtakunnallinen edustajakokouksessa, joka pidettiin Tampereella 13.-17.1.1908. Kokouksessa oli 406 osanottajaa eli enemmän kuin edellisessä maanvuokraajakokouksessa. Osanottajat edustivat noin 41000 maanvuokraajaa ja noin 21000 muuhun tilattomaan väestöön kuuluvaa henkilöä. Kokous oli edellistäkin kertaa selvemmin sosialidemokraattien johtama ja sen päätökset olivat

341 Gylling 1907 I.

342 Gylling, Edvard, Suomettarelaisten maatalousohjelmasta. Sosialidemokraatti 14.5.1908 (G). 
oikeastaan vain edellisen maanvuokraajakokouksen vaatimusten vahvistamista. ${ }^{343}$

SDP:n puoluetoimikunnan edustajina olivat kokouksessa muun muassa Yrjö Sirola, Sulo Wuolijoki ja Edvard Gylling. Gylling alusti kokoukselle torpparihäätöjen estämistä. Alustus julkaistiin hieman muutettuna Sosialistisessa Aikakauslehdessä ja Työmiehessä. ${ }^{344}$ Gylling kannatti ensimmäisen kokouksen päätöksiä: häädetyn pitäisi saada korvaus torpan raivauskustannuksista ja häätöjen estämiseksi olisi tuettava voimakasta maanvuokraajien järjestäytymistä. Sosialidemokraatit olivat ehdottaneet valtiopäivillä, että nykyisen maanvuokralain aikana häädettyjen maanvuokraajien oli päästävä takaisin tai saatava korvaus. Ehdotus ei saanut tukea muiden puolueiden taholta, mutta painostuksella ennen vaaleja olisi ehkä mahdollista saada jokin porvaripuolue ehdotuksen taakse ja varmistaa sen läpimeno. Eräs keino maanvuokraajien häätöjen estämiseksi olisi ollut väliaikainen laki, jolla ei kuitenkaan ollut mitään kannatusta porvarillisten puolueiden taholta. Häätöjä ei siis pystytty estämään, mutta siihen kannatti edelleen pyrkiä sekä lainsäädännön että järjestäytymisen avulla. ${ }^{345}$

Gylling korosti maanvuokratilaston merkitystä. Hän totesi, että tilastoa pitäisi alkaa kerätä välittömästi ja valmistumisen jälkeen se pitäisi heti julkaista. Gyllingin mukaan tästä voisi olla ainakin seuraavat neljä hyötytekijää: helpottaisi korvausten laskemista, voimistaisi maanvuokraajien yhteishenkeä, pidättäisi ehkä maanomistajia häädöistä ja paljastaisi yhteiskunnalle tilanteen. ${ }^{346}$ Tässä näkyy jälleen Gyllingin vankkumaton usko tilastoihin yhteiskunnallisen uudistustyön ja vaikuttamisen perustana, jonka hän sai vietyä myös kokouksen lopullisiin päätöksiin.

343 Maanvuokraajien toisen yleisen edustajakokouksen ptk., Helsinki 1908, s.54-57. Edustajien määrä oli monissa valtakirjoissa pyöristettynä, joten tarkkoja lukuja on mahdoton antaa; vrt. Rasila 1961, s.412.

344 Gylling, Edvard, Torpparihäätöjen estäminen . SosA 37/1908 (A), s. 3-7.

345 Maanvuokraajien toisen yleisen edustajakokouksen ptk., Helsinki 1908, s.22-24.

346 Maanvuokraajien toisen yleisen edustajakokouksen ptk., Helsinki 1908, s. $25-26$ 
Maanvuokraajakokous kannatti eduskunnan maatalousvaliokunnan sosialidemokraattisten jäsenten tekemän vastalauseen mukaista maanvuokralakia vain sillä poikkeuksella, että kun vastalauseessa oli esitetty talvipäivän pituudeksi kahdeksan tuntia, niin kokous päätti edellisen kokouksen tapaan vaatia seitsentuntista talvipäivää. Tämä linjaus tarkoitti sitä, että nykyisen maanvuokralain aikana irtisanotut maanvuokraajat on otettava takaisin tai heille on maksettava korvaus. Lisäksi kokous totesi, että oli pyrittävä edelleen ehkäisemään häätöjä voimakkaan järjestäytymisen avulla sekä kehotti aloittamaan maanvuokraajatilaston kokoamisen ja julkaisun. Kokous otti myös sen kannan, ettei sosialidemokraattien ole suostuttava mihinkään "puolittaisiin uudistuksiin" vaan että jos kunnollista lakia ei eduskunnassa saada aikaan, asia on äänestettävä lepäämään yli vaalien. ${ }^{347}$

Gylling alusti kokoukselle myös kysymyksen viljelyspakosta. Hän toisti edellisen maanvuokraajakokouksen teesit ja ehdotti lisäksi, että maanomistajalle viljelyksestä lankeava vuotuinen vero voisi olla alueen puhdas tuotto ennen viljelykseen ottamista. Ehdotus sai viljelyspakkovaliokunnassa yksimielisen kannatuksen. Gylling, Sirola ja Wuolijoki valittiin edelleen torpparien keskustoimikuntaan. ${ }^{348}$

Gylling kirjoitti kokouksesta artikkelin, jossa hän selosti kokouksen kulkua. Hän vaikutti varsin tyytyväiseltä tehtyihin päätöksiin. Erityisesti hän mainitsi, että pohjanmaalaisetkaan maanvuokraajat eivät tällä kertaa erottuneet valtalinjasta kuten viime kokouksessa. Syynä tähän oli se, että sieltä tulleet edustajat olivat vaihtuneet jyrkempiin. ${ }^{349}$

347 Maanvuokraajien toisen yleisen edustajakokouksen ptk., Helsinki 1908, s.54-57; Rasila 1961, s.412-413.

348 Maanvuokraajien toisen yleisen edustajakokouksen ptk., Helsinki 1908, s.51-53.

349 Gylling, Edvard, Suomen torpparien toinen edustajakokous Tampereella. SosA 37/1908 (B), s.28-30. 


\section{Kansanedustajaksi}

Vuoden 1906 voimaan tulleella valtiopäiväjärjestyksellä toteutettiin kansaneduslaitoksen suuri uudistus. Tällöin 1600-luvulta periytynyt nelisäätyinen valtiopäivälaitos korvattiin 200-jäsenisellä yksikamarisella eduskunnalla. Uuden valtiopäiväjärjestyksen mukaan kansanedustajien valinta tapahtui välittömillä, suhteellisilla ja salaisilla vaaleilla vaalipiireittäin. Eduskunta kokoontui valtiopäiville vuosittain, joten lainsäädäntötyöstä tuli säännöllistä ja jatkuva.

Uuden valtiopäiväjärjestyksen mukaan äänioikeus oli yleinen ja yhtäläinen. Äänestämään pääsy ei enää ollut kiinni sosiaalisesta asemasta tai sukupuolesta. Uudistus lisäsi äänioikeutettujen määrän kymmenkertaiseksi verrattuna säätyvaltiopäivien aikaan. Äänioikeuden sekä vaalikelpoisuuden ikäraja oli 24 vuotta. Valtiopäiväuudistus oli kansainvälisesti varsin radikaali ja Suomen naiset pääsivät ensimmäisinä maailmassa käyttämään valtiollisia oikeuksiaan, sekä äänioikeutta että oikeutta asettua vaaleissa ehdolle. Tämän suuren murroksen myötä aikalaiset kokivat elävänsä ainutlaatuisessa murroksessa, joka muuttaisi heidän elämänsä ja siirtäisi vanhat epäoikeudenmukaisuudet historiaan. Ensimmäisiin eduskuntavaaleihin lähdettiin tosimielellä ja uskoen poliittisen vaikuttamisen voimaan. Uusi valtiopäiväjärjestys merkitsi erityisesti SDP:lle ja maalaisliitolle kansanvallan voimannäytettä, joka mahdollisti turmeltuneen säätyvallan syrjäyttämistä edistyksen tieltä. Sosialidemokraatit lähtivätkin eduskuntatyöhön tavoitteenaan saada aikaan yhteiskunnallisia uudistuksia, mutta käytännössä he joutuivat erinomaisesta tuloksesta huolimatta altavastaajan asemaan. Kaiken kaikkiaan eduskunnasta tulikin alkuvaiheessa ennen kaikkea puolueiden välisten sanallisten mittelyjen foorumi ja näyttämö poliittiselle agitaatiolle. ${ }^{350}$

SDP:n menestys oli vuoden 1907 eduskuntavaalissa yllättävän suuri ja siitä tuli eduskunnan suurin puolue. Suomalainen Puolue

350 Soikkanen 1975, s.126-127; Vares, Vesa, Demokratian haasteet 1907-1919,. Teoksessa Kansanvalta koetuksella. Suomen eduskunta 100 vuotta 3. Toim. Majander, Mikko, Uola, Mikko, Vares, Vesa. Helsinki 2006, s.11, 19. 
saavutti selvästi toiseksi suurimman puolueen aseman. Tulos oli seuraava:

$\begin{array}{lr}\text { SDP } & 80 \\ \text { RKP } & 24 \\ \text { Suomalainen Puolue } & 59 \\ \text { Maalaisliitto } & 9 \\ \text { Nuorsuomalainen Puolue } & 26 \\ \text { Kristillinen työväki } & 2\end{array}$

Vaaleissa käytti äänioikeuttaan yllättävän moni eli noin 70,7 \% äänioikeutetuista. Suomessa sosialismin kannatus oli poikkeuksellisesti maaseudulla huomattavasti suurempaa kuin kaupungeissa. Gyllingin mukaan tämä johtui siitä, että suurteollisuuden kehittymättömyyden takia teollisuustyöväestöä oli vähän ja että suuri osa kaupunkilaisväestöstä oli ruotsinkielisiä, joiden keskuudessa sosialismilla oli varsin vähän kannatusta. ${ }^{351}$

Gylling vertasi vaalien tulosta väestön luokkarakenteeseen. Hän jaotteli väestön vuoden 1905 henkiluettelon perusteella "porvareihin" ja "köyhälistöön". Edelliseen ryhmään hän laski talolliset, kruununtilanhaltijat, muun elinkeinon kuin maanviljelyksen itsenäiset harjoittajat, koroillaan elävät, konttoripalvelijat, työnjohtajat sekä muut käskyläiset perheineen. Jälkimmäiseen ryhmään hän laski torpparit ja lampuodit, vakinaiset työmiehet teollisuuden ja maanviljelyksen alueilla sekä työttömät. ${ }^{352}$

Gyllingin luokittelu perustui melko selvästi tuotannonvälineiden omistamiseen, kuten marxilaiseen teoriaan kuuluu. Lisäksi hän laski porvareihin työnjohtajia sekä muita vastaavia ammattiryhmiä, jotka eivät omistaneet tuotantovälineitä. Tämäkin sopi marxilaiseen ajatteluun, sillä Kautskyn mukaan nämä väliryhmät

351 Gylling, Edvard, Katsaus viime eduskuntavaaleihin, Työväen Kalenteri I/1908, 1907 (H), s.70-74. Tämä arvio pitikin ilmeisesti varsin hyvin paikkansa ja kaikkein pienintä puolueen kannatus oli ruotsinkielisissä pikkukaupungeissa. Vrt. Soikkanen 1975, s.176-179.

352 Gylling 1907 H, s.74-75. Tosin Gylling näyttäisi aliarvioivan ainakin maaseudun maataomistavan viljelijäväestön lukumäärän. Arvo M. Soinisen laskelmien mukaan se oli noin 40 \%. Soininen 1976, s. 223. 
menettivät jatkuvasti merkitystään, jolloin luokkataistelu kärjistyi kapitalistien ja proletariaatin väliseksi. ${ }^{353}$

Gylling esitti seuraavan taulukon yhteiskunnan luokkarakenteesta:

$\begin{array}{lccr} & \text { maaseudulla } & \text { kaupungeissa } & \text { koko maa } \\ \text { porvareita } & 35,6 \% & 41,0 \% & 36,2 \% \\ \text { köyhälistöä } & 63,2 \% & 56,0 \% & 62,4 \% \\ \text { muuta väestöä* } & 1,2 \% & 3,0 \% & 1,4 \% \\ \text { yhteensä } & 100,0 \% & 100,0 \% & 100,0 \%\end{array}$

*etupäässä väkeä, joka ei oleskele paikkakunnalla

Lähde: Gylling, Edvard, Katsaus viime eduskuntavaaleihin, Työväen Kalenteri I/1908.

Gylling totesi optimistisesti, että jos koko köyhälistö saataisiin äänestämään SDP:tä, menestys olisi vielä selvästi parempi. Kun "suuri herätystyö" saadaan tehtyä, eduskuntaan voisi tulla vasemmistoenemmistö. ${ }^{354}$

Muitakin johtavia sosialidemokraattisia poliitikkoja mietitytti puolueen asema suhteessa Suomen luokkarakenteeseen. Otto Ville Kuusinen määritteli sosialidemokraattisen puolueen olleen tuolloin kansanpuolueen ja palkkatyöväenpuolueen välimuoto. K. H. Wiik taas uskoi, että torpparit olisivat liittyneet radikaaliin porvari- tai talonpoikaispuolueeseen, jos sellainen olisi ollut olemassa. ${ }^{355}$

Nykytutkimuksen näkökulmasta Gyllingin tekemä jaottelu on yksinkertaistava ja liikaa dualistiseen luokkarakenteeseen nojautuva, vaikkakin kuvastaa hyvin aikakaudelle tyypillistä jakoa herroihin ja rahvaaseen. Hannu Soikkasen mukaan sosialidemokraattien kannatuksella ja maatalousväestön rakenteella oli kuitenkin selvä riippuvuus. Maanvuokraajien ja muun tilattoman

353 Gronow 1986, s.45.

354 Gylling 1907 H, s.75-76.

355 Peltonen 1992, s.256. 
väestön suuri osuus korreloi positiivisesti sosialidemokraattien kannatuksen kanssa. Soikkanen nosti lisäksi tärkeäksi kannatusta selittäväksi tekijäksi myös alueen läheisyyden työväenliikkeen keskuksiin ja siitä johtuvan puolueen vaalityön kattavuuden. ${ }^{356}$

Viljo Rasila korostaa kuitenkin, että 1900-luvun alun yhteiskunta oli hyvin monikerroksinen luokkien sisälläkin, mutta toisaalta keskiluokkaan lukeutui paljon ihmisiä. Hänen analyysinsä pohjalta esimerkiksi torpparit voidaan laskea yhteiskunnan keskiluokkaan, vaikka tämänkin ryhmän sisäiset erot olivat suhteellisen suuria. Torpparit ja osin pientilallisetkin jäivät luokka-asemansa suhteen eräänlaiseen väliasemaan kun taas yhteiskunnan aivan alimpien kerrosten väestö oli poliittisesti varsin passiivista. ${ }^{357}$ Torpparien asemaa kuvaa sekin, että heitä oli mukana vuoden 1918 sisällissodan molemmilla puolilla varsin tasaisesti, joskin Etelä-Suomessa selvästi enemmän punaisten ja Pohjois-Suomessa valtaosin valkoisten puolella. ${ }^{358}$

Gylling joka tapauksessa uskoi vahvasti eduskunnan kautta tapahtuvaan reformipolitiikkaan. Vuoden 1907 vaalien tuloksen selvittyä sekä SDP:n johto että kannattajat odottivat yleisestikin ottaen eduskunnalta paljon. Tämä luottamus eduskuntatyöhön säilyi vuoden 1908 toisiin valtiopäiviin asti. Tällöin tsaarinvallasta alkoi entistä korostetummin tulla sosiaalipoliittisen lainsäädännön jarru. ${ }^{359}$

Gylling ei asettunut ehdolle vuoden 1907 valtiopäivävaaleissa, vaikka ehdokkaina oli monia muita marraskuun sosialisteja, kuten Kuusinen, Tanner ja Sulo Wuolijoki. Varmaa selitystä Gyllingin poisjäännille ei voi antaa. Todennäköisesti häntä kiinnosti tuolloin ensisijaisesti väitöskirjan tekeminen ja tieteellinen ura, jolle politiikka oli alisteista. Toisaalta kansanedustajan toimi ei ollut tuolloin lähellekään ympärivuotinen, sillä eduskunta oli koolla vain kolme kuukautta vuodessa. Gylling sai kuitenkin kokemusta

\footnotetext{
356 Soikkanen 1975, s.173-175.

357 Rasila 1995, 305-312.

358 Haapala 1993, s.108-109.

359 Soikkanen 1975, s.124-128.
} 
valtiopäivien toimintatavoista, kun hän toimi vuonna 1907 maatalousvaliokunnan sihteerinä. ${ }^{360}$

Gylling kytki kansanedustajien toiminnan varsin suoraan hänen edustamiensa kansanryhmien etuihin. Gyllingin voi jopa katsoa kannattaneen niin sanottua imperatiivista mandaattia, jonka mukaan edustajien pitäisi olla epäitsenäisesti sidottuja valitsijoidensa kantoihin. Hän nimittäin totesi, että kansanedustaja oli ainoastaan "valitsijain toimitsija, joka ajaa asioita eduskunnassa siten kuin valitsijat katsovat ja puolueen ohjelma määrää". Kaiken kaikkiaan Gylling kannatti parlamentaarisen työn tukemista aktiivisen jäsenhankinnan, luokkatietoisuutta lisäämisen, luokkarajojen selventämisen, ammattijärjestöjen ja osuustoimintaliikkeen vahvistamisen sekä valistustyön avulla. Hänen mukaansa sosialidemokraattisten edustajien sanoilla on paljon enemmän painoa, kun suuret kansanjoukot seisoivat itsetietoisina heidän takanaan. Hän varoitti edustajia tinkimästä liikaa päämääristään ja suostumasta porvarien "puoliparannuksiin". Erityisesti tärkeää tämä oli SDP:n tärkeimpien uudistusvaatimusten, uuden maanvuokralain ja viljelyspakon, kohdalla. ${ }^{361}$

Gylling painotti eduskuntatyön tärkeyttä, mutta samalla varoitti liiallisesta kompromissihalukkuudesta porvarillisten ryhmien kanssa. Tämä kaksijakoinen linja oli tuolloin suomalaisten sosialidemokraattien yleinen linja. Suurlakon tuloksena saatu kansanvaltaista edustuslaitos haluttiin säilyttää, mutta kuitenkin pitää raja porvarillisiin puolueisiin selvänä. ${ }^{362}$

Vuoden 1907 valtiopäivien jälkeen Gylling kirjoitti, että ensimmäistä kertaa valtiopäivillä käsiteltiin kansan kannalta todella merkittäviä kysymyksiä. Suuri osa tärkeimmistä lainsäädäntökysymyksistä käsitteli maataloutta. Tilattoman väestön kasvu ja maanvuokraajien aseman huonontuminen synnytti "taistelevan köyhälistön puolueen" porvarillisten puolueiden rinnalle. Saadak-

360 Rasila 1961, s.409.

361 Gylling, Edvard, Työhön kaikki!, SosA 30/1907 (E), s.169.171.

362 Ks. esim. Soikkanen 1975, s.120-148 ja Ehrnrooth 1992, s.87-92, 184. 
seen kannatusta niidenkin oli ollut pakko muuttua entistä enemmän "herraspuolueista" kansanpuolueiksi. ${ }^{363}$

Gyllingin mukaan porvarilliset puolueet olivat yhtä mieltä siitä, että tilattomalle väestölle olisi saatava tiloja. Kysymystä tarkennettaessa syntyi eroa: RKP ja nuorsuomalaiset ajoivat lähinnä suurtilallisten etuja, kun taas vanhasuomalaiset pyrkivät saamaan kannatusta keskikokoisten ja pienten tilojen viljelijöiltä. Tärkein maatalouskysymyksistä oli uusi maanvuokralaki, jonka sisällöstä porvarilliset ryhmät olivat myös eniten erimielisiä. Oikeisto pyrki ratkaisemaan asian maanomistajan omistusoikeutta loukkaamatta, kun taas keskusta oli valmis huomattavasti radikaalimpiin toimenpiteisiin. Porvarilliset puolueet eivät maatalouskysymyksessä päässeet valtiopäivillä kompromissiin, joka olisi ollut uudistusten edellytys. ${ }^{364}$

Gylling katsoi, että porvarit pyrkivät turvaamaan nykyisen järjestelmän tekemällä varovaisia uudistuksia ja samalla vähitellen lisäämällä omistavien henkilöiden lukumäärää. Sosialidemokraattien näkökulma oli aivan toinen kuin porvarillisilla puolueilla. Yhteiskuntaa ei voitu nopeasti muuttaa sosialistiseksi, mutta oli mahdollista tehdä uudistuksia, jotka edistivät taloudellisia oloja. Hänen mielestään oli selvää, että maan rajoittamaton omistusoikeus oli taloudellisesti turmiollista. Gylling totesi tässä Kautskyn näkemyksiä mukaillen, että myös maaseutuköyhälistön luokkataistelu oli tärkeä yhdistää yhteiskunnan yleiseen edistymiseen. Gylling uskoi, että jos porvarit eivät pystyneet tulokselliseen uudistuspolitiikkaan maatalouskysymyksessä, sosialidemokraattinen politiikka voittaa alaa. ${ }^{365}$

Keisarillinen Venäjä oli kesään 1907 mennessä selvinnyt suurlakon synnyttämästä kriisistä ja saattoi taas koventaa politiikkaansa, mikä johti venäläistämistoimenpiteiden kiristymiseen Suomessa. Keväällä 1908 eduskunnassa tehtiin kolme välikysymystä koskien Leo Mechelinin (1839-1914) johtaman senaatin toimenpiteitä

363 Gylling, Edvard, Päättyneet valtiopäivät ja maakysymys, SosA 34-35/1907 (G), s.306-307.

364 Gylling 1907 G, s.307-309.

365 Gylling 1907 G, s.309-310; vrt. Kautsky 1899 (1988), s. 313-329. 
Suomen aseman puolustamisessa. Kiristyvä tilanne johti senaatin eroamiseen huhtikuussa 1908, minkä jälkeen venäläiset hajottivat eduskunnan huhtikuun alussa ja määräsivät uuden eduskunnan kokoontumaan saman vuoden elokuussa. ${ }^{366}$

Gylling asettui ehdokkaaksi 1.-2.7.1908 järjestettyyn valtiopäivävaaliin Turun Pohjoisesta vaalipiiristä. Päätöksen taustalla oli mahdollisesti se, että Sosialistisen Aikakauslehden lopettaminen toi hänelle lisää vapaa-aikaa tai ehkä venäläistämistoimenpiteiden kiristyminen lisäsi halua vaikuttaa eduskunnassa. Saattoi myös olla, että häneen otettiin yhteyttä puoluejohdon taholta. Joka tapauksessa Gylling sai puolueen äänestyksessä vaalipiirin eduskuntaehdokkaista eniten ääniä. Hän sai suhteellisen tasaisesti ääniä vaalipiirin eri valitsijayhdistyspiireistä. Ikaalisten sosialidemokraatit tukivat oman kylän poikaa kuitenkin lähes yksimielisesti. ${ }^{367}$

Gylling valittiin kansanedustajaksi ensimmäisen kerran vuoden 1908 toisille valtiopäiville. Tämän jälkeen hän oli mukana kaikilla valtiopäivillä ennen sisällissotaa lukuun ottamatta vuoden 1910 valtiopäiviä. Yleensä Gylling oli vaalipiirissään kärkisijalla sekä puolueäänestyksessä että varsinaisessa vaalissa.

Väitöskirja torpparilaitoksen historiasta

Politiikassa aktivoituminen ei merkinnyt Edvard Gyllingin tutkimustoiminnan loppumista. Hän oli keväällä 1904 Saksan matkansa aikana päättänyt suorittaa tohtorin tutkinnon. Saksasta tultuaan hän aloittikin väitöskirjan tekemisen loppuvuodesta 1904

366 Tuominen, Uuno, Autonomian ajan yksikamarinen eduskunta 1907-1916. Teoksessa Suomen kansanedustuslaitoksen historia V. Helsinki 1958, s.183190; Jussila 1979, s.207-208.

367 TA, Turun läänin Pohjoisen sos.dem. piirin aineistoa. Vuonna 1909 Mimmi Kanervo oli toinen ja seuraavana vuonna kolmas. Toiseksi eniten ääniä vuonna 1910 keräsi Nestori Aronen. Toimittaja Väinö Tanner oli vuonna 1909 viides ja vuonna 1910 kahdeksas. Keittiönomistaja Eetu Salinin sijaluvut olivat päinvastaiset. 
tai alkuvuodesta $1905{ }^{368}$ Väitöskirja valmistui reilut neljä vuotta myöhemmin.

1900-luvun alussa tohtorinarvo saatiin siten, että väiteltiin lisensiaatinväitös. Tämän jälkeen tiedekunta saattoi anomuksesta myöntää tohtorin arvon. Edvard Gyllingin väitöskirjan julkinen tarkastaminen oli 26.5.1909. Vastaväittäjänä oli pohjoismaiden historian dosentti Väinö Voionmaa, joka oli yhteiskuntahistoriallisen lähestymistavan edelläkävijöitä Suomessa. Gyllingin arviot Voionmaan huomioista selviävät hänen kokoelmastaan löytyvästä vastaväittäjän lausunnosta, missä on myös Gyllingin merkintöjä. ${ }^{369}$

Väinö Voionmaa oli sosiaalihistorioitsija, joka oli saanut vaikutteita ennen kaikkea lamprechtilaisuudesta. Hän antoi arvoa myös marxilaiselle historiankäsitykselle, mutta suhtautui siihen vain näkökulmana muiden joukossa. Poliittisesti Voionmaa kuului sosialidemokraattien oikeistosiipeen, joka tulkitsi marxilaista sosialismia varsin maltillisesti. Hän oli omaksunut sosialidemokraattisen ajattelutavan ilmeisesti jo ennen suurlakkoa ja liittynyt puolueeseen viimeistään vuonna $1906 .{ }^{370}$ Vielä Saksan matkansa aikana Gylling suunnitteli väittelevänsä ilmaston merkityksestä maatalousolojen kehitykselle Pohjois-Euroopassa. Tutkimusaihe muuttui pian Suomen torpparilaitoksen historiaksi, jolle myönnettiin kaksi vuotta ennen väitöstä painatuslupa. Gylling rajasi myöhemmin käsittelyn aikarajaksi Ruotsin vallan ajan. Todennäköisesti hän katsoi käsittelyn ulottamisen autonomian aikaan olevan liian laaja tehtävä. ${ }^{371}$

368 KA, EGK, kansio 5, Edvard Gyllingin kirje Fanny Achrénille 13.4. 1904.

369 KA, EGK, kansio 1, ote Filosofisen tiedekunnan Historiallis-kielitieteellisen osaston ptk.:sta 6.10.1909 liitteineen.

370 Halila, Aimo, Väinö Voionmaa. Helsinki 1969, s.104-105. Lähteenmäki, Maria, Väinö Voionmaa. Puolue- ja geopoliitikko. Historiallisia tutkimuksia 264. Helsinki 2014, s. 62-72. Lähteenmäki on alkuperäislähteiden avulla kumonnut Halilan esittämän näkemyksen, jonka mukaan Voionmaa olisi liittynyt SDP:n jäseneksi vasta sisällissodan jälkeen. Edvard Valpas tosin vieroksui hänestä liian herraskaista ja oppinutta Voionmaata, joka ei edennytkään puolueessa keskeisiin tehtäviin ennen sisällissotaa.

371 Heikkinen - Mauranen 1985, s.96. 
Gyllingin poliittinen toiminta ja tutkimustyö olivat läheisessä yhteydessä toisiinsa. Uutta maanvuokralakia laadittiin valtiopäivillä samaan aikaan kun Gylling viimeisteli väitöskirjaansa Suomen torpparilaitoksen historiasta. Ei ole kuitenkaan yllättävää, että aiheena oli nimenomaan maanvuokrauksen historia. Gylling korosti yhteiskunnallisissa kysymyksissä usein historiallista näkökulmaa, mikä osoittaa saksalaisen kansantaloustieteen historiallisen koulukunnan vaikuttaneen vahvasti hänen ajatteluunsa. Tosin myös marxilainen ajattelu pohjautui vahvaan historialliseen analyysiin, joka kuitenkin pyrittiin yhdistämään teoreettiseen viitekehykseen. Gylling oli jo pro gradussaan valitellut, että tärkeä historiallinen näkökulma jäi työssä vähiin. Pro gradun jälkeisissä artikkeleissa lähdettiin usein liikkeelle menneestä kehityksestä. Väitöskirjansa hän tekikin sitten torpparilaitoksen historiasta.

Gylling julkaisi vuonna 1909 väitöskirjansa aiheesta Suomen torpparilaitoksen kehityksen pääpiirteet Ruotsinvallan aikana. Hänen koulutoverinsa Martti Kovero väitteli aiheesta Valtion uutisasutus Ruotsi-Suomessa jälkeen Ison-vihan lähes samanaikaisesti. Torpparilaitos ja valtion uudisasutus olivat 1700-luvun asutuspolitiikassa vaihtoehtoisia ja osin rinnakkaisia välineitä. Gylling ja Kovero olivatkin ilmeisesti tutkimuksia tehdessään yhteistyössä.. ${ }^{372}$

Gyllingin väitöskirjan tekstiosan pituus on 247 sivua. Teokseen sisältyy lisäksi 105 sivuinen tilasto-osa, joka sisältää sekä varsinaisia tilastoja että sanallista selvitystä. Väitöskirja edusti uudenlaista historiallista tutkimusotetta yhteiskuntahistoriallisen aiheensa lisäksi myös siinä, että päätelmät pohjautuivat perusteelliseen tilastolliseen analyysiin. Tilastoja on tilasto-osan lisäksi myös tekstiosassa.

Yleensä konkreettisesta sosiaalitutkimuksesta lähtevät tutkimukset käsittelivät lähimenneisyyttä, mutta Gyllingin lähtökohtana oli maaseudun ongelmien valaiseminen pidemmällä perspektiivillä. Väitöskirja oli ennen kaikkea historiatieteellinen tutkimus. Gyllingin poliittisille teksteille ominaista voimakasta retoriikkaa ei esiinny lainkaan ja tutkimusajankohdan yhteiskuntaan viita-

372 Heikkinen - Mauranen 1985, s.96-97. 
taan vain muutaman kerran. ${ }^{373}$ Kirjan lopussa Gylling viittasi tutkimusajankohtaan seuraavasti:

Vasta 1800-luvun loppupuolella alkavat ne uudet virtaukset maatalousoloissamme esiintyä, joiden mullistava vaikutus nykyään on niin selvästi havaittavissa. Edellä oleva tutkimus on näin ollen vain käsitellyt torpparilaitoksemme esihistoriaa... ${ }^{374}$

Gylling kuljetti tutkimuksessaan rinnakkain Ruotsin valtakunnallisen tason politiikkaa ja Suomen alueen kehitystä. Gylling käsitteli valtakunnallisella tasolla lähinnä uudisasutukseen ja torpparilaitokseen vaikuttanutta lainsäädäntöä sekä suppeammin hallinnon toimintaa ja taustalla vaikuttaneita talousteoreettisia aatevirtauksia. Välillä teoksessa on varsin oikeushistoriallinen ote. Pekka Haatasen mukaan Gyllingin väitöskirja oli ensimmäinen suomalainen laaja tutkimus, missä tietty väestönosa otettiin tutkimuksen kohteeksi. Haatasen mukaan Gylling tutki torpparilaitoksen kehitystä oikeushistorialliselta kannalta, eikä hän kiinnittänyt paljoakaan huomiota torpparien oloihin sosiaalihistorialliselta kannalta. ${ }^{375}$

Gylling itse määritteli kuitenkin väitöskirjansa ennen kaikkea taloushistorialliseksi tutkimukseksi. Hän määritteli tutkimuksen kysymyksenasettelun seuraavasti:

Seuraavan tutkimuksen tarkoituksena on selvitellä meidän nykyisen yksityisoikeudellisella maalla olevan torpparilaitoksemme syntyä ja kehitystä. Erityisesti tulee tällöin luonnollisesti sitä torppariasutuksen kehitystä seurattavaksi, jonka ovat aiheuttaneet puhtaasti taloudelliset syyt, s.o. uutisasutus pyrkimykset ja vanhemman asutuksen työntarve. Muut torpparilaitoksen kehitysmuodot ovat sen vuoksi jätetyt syrjään. Samalla on myöskin,

373 Gylling, Edvard, Suomen torpparilaitoksen kehityksen pääpiirteet Ruotsinvallan aikana. Taloustieteellisiä Tutkimuksia IX 1909. Helsinki 1909 (A), esim. s.64, 190.

374 Gylling 1909 A, s.247.

375 Haatanen, Pekka, Sosiaalihistoria. Teoksessa Suomalaisen sosiologian historia. Toim. Alapuro, Risto et al. Juva 1992, s.155. 
kuten jo edellä esitetystä selviää, vuokrasuhde s.o. torpparin ja maanomistajan välisten oikeussuhteiden kehitys jätetty tutkimuksen ulkopuolelle. ${ }^{376}$

Gylling kirjoitti, että "torppa" on sekä historiallisesti että nykyaikana vaikeasti määriteltävä käsite. Hän kuitenkin katsoi, että "torppa on vuokralle annettu tilanosa, jossa on viljeltyä maata, viljelijän asunto ja useimmiten muitakin itsenäisen viljelyksen mahdollistamia edellytyksiä..." Maanviljelyksellä oli torpan taloudelle suhteellisen suuri merkitys, vaikka se ei aina yksin kyennyt torpparia ja hänen perhettään elättämään. Torppaa pienempiä yksiköitä olivat tölli ja mäkitupa, mutta itsenäisen pienviljelijän tilat olivat sitä suurempia. ${ }^{377}$

Yleisesti on todettu, että Gylling oli tutkijana enemmän käytännöstä lähtevä empiirikko kuin teoreetikko. ${ }^{378}$ Väitöskirjassakaan ei ole varsinaista teoreettista lähtökohtaa, jonka vierastaminen oli tosin tutkimusajan historiantutkimuksille yleistä. Gylling ei suoranaisesti lähtenyt historiallisesta materialismista, mutta hänen tulkintansa lähestyivät marxilaisia näkemyksiä. Hän totesi torpparilaitoksen kehityksestä seuraavaa:

..olivat molemmatkin, sekä torpparilaitos että torpparilainsäädäntö lähinnä saman perussyyn, kehittyvän suurviljelyksen ja sen maatyötarpeen kasvattamat. Mutta toiselta puolen ei voine kieltää, että torpparilainsäädäntö torppariasutuksen viitattuun suuntaan kehittymistä puolestaan edisti ja joudutti. ${ }^{379}$

Tämä tulkinta sopii hyvin Marxin materialistiseen historiallisen kehityksen malliin, missä niin sanottu yhteiskunnan perusta eli viime kädessä tuotantovoimat toimii kehityksen moottorina ja

376 Gylling 1909 A, s.4.

377 Gylling 1909 A, s.1-2.

378 Heikkinen - Mauranen 1983, s.19-20; Alapuro - Alestalo 1992, s.88; Ehrnrooth 1992, s.257.

379 Gylling 1909 A, s.70. Myös sivuilla 138 ja 218 Gylling esitti samansuuntaisen tulkinnan kehityksestä. 
yhteiskunnan niin sanottu päällysrakenne reagoi muutoksiin. ${ }^{380}$ Tosin taloudellisia tekijöitä historiassa painottivat myös Karl Lamprecht ja kansantaloustieteen historiallisen koulukunnan edustajat, joista Suomessakin saatiin paljon vaikutteita. ${ }^{381}$ Lamprechtin historiankäsitys oli kuitenkin varsin ristiriidaton verrattuna marxilaisiin näkemyksiin, missä luokkataistelu vie historiaa dialektisesti eteenpäin. Gyllingin väitöskirja ei ole yhteiskunnallisen harmonian historiaa. Teoksessa mainitaan vähän väliä voimakkaat vastakohtaisuudet eri yhteiskuntaryhmien välillä. Ennen 1700-luvun puoltaväliä kyseessä oli lähinnä aatelin ja talonpoikien väliset ristiriidat. ${ }^{382}$

Gyllingin mielestä 1700-luvun puolivälissä pyrittiin tietoisesti synnyttämään maaseudulle talollisluokan alapuolelle palkkatyöstä riippuvainen työväenluokka, koska sitä kautta voitaisiin ratkaista kasvava työvoiman tarve. Torpparilaitoksen kehittämisen puolesta puhui myös se, että tuolloin uskottiin suurviljelyksen tehokkuuteen. Maatalouden kannalta parhaalta ratkaisulta näyttikin varakkaiden omistamat suurtilat, joilla työskenteli paljon alustalaisia ja torppareita. Tuolloinkin tuotiin kuitenkin esille torpparilaitoksen huonoja puolia, kuten torpparien hallintaoikeuden ja vuokramaksun epämääräinen luonne. ${ }^{383}$

380 Ks. esim. Engels - Marx 1970 (1845-1846), s.33-34.

381 Lamprechtin käsitys taloudellisten tekijöiden ehdottomasta ensisijaisuudesta tosin heikkeni aivan 1800-luvun viimeisinä vuosina. Kuitenkin hän painotti niitä historian muutosvoimana tämänkin jälkeen enemmän kuin esim. aatteellisia ja poliittisia syitä. Viikari, Matti, Die Krise der "historischen" Geschichtsschreibung und die Geschichtsmethodologie Karl Lamprechts. Disertationes Humanarum Litterarum 13. Helsinki 1977, s.244-255; Suomalaisista lamprechtilaisista vaikutteista ja tutkimuksesta tarkemmin Tommila 1989, s.135-136, 147-149.

382 Gylling 1909 A, esim. s.26, 53, 92.; vrt. myös Ek 1994,s.46.

383 Gylling 1909 A, s.132-137. Topi Kallio on esittänyt samansuuntaisia arvioita muutama vuotta myöhemmin tehdyssä tutkimuksessaan. Hänen mukaansa palveluspakkoa perusteltiin sillä, ettei syntyisi työvoimanpuutetta säätyläisille. Tämä asenne muuttui kuitenkin jonkin verran 1700- ja 1800-lukujen taitteessa. Kallio, Topi, Palvelijapolitiikasta Suomessa 18. vuosisadalla. Taloustieteellisiä Tutkimuksia XI. Helsinki 1913, s.56-70; Myöhemmistä 
Gylling johti valtiollisen vaikutusvallan tuotantovälineiden omistussuhteista varsin marxilaissävytteisesti:

Että tämä puoli asiasta sai tavallista enemmän huomiota osakseen, on selvä, kun pitää mielessä, miten suuri valtiollinen vaikutusvalta on juuri niillä väestö luokilla, jotka käyttivät palkkatyötä maanviljelyksessä ja kuinka hyvin tähän saakka oli tämän työtarpeen tyydyttämisestä pidetty huolta. ${ }^{384}$

Huolimatta tästä Gyllingin tutkimuksessa käyttämät käsitteet olivat varsin yleisluontoisia, vaikka joillakin niistä saattoi olla marxilainen alkuperä. Tällaisia käsitteitä olivat esimerkiksi "yhteiskuntataloudelliset voimat", "väestöluokka" tai "tuotantotapa". Gyllingin käyttämässä kirjallisuudessa ei juuri ole marxilaista tutkimusta, jota toisaalta tuolloin oli - ainakin maatalousoloista - tehty varsin vähän.

Gyllingin oppi-isä Hannes Gebhard oli vanhasuomalaisena sosiaalireformisti mutta ei marxilainen. Myös Gebhard käytti käsitettä "yhteiskuntataloudelliset olot", jonka hän ymmärsi melko samoin kuin Gylling. ${ }^{385}$ Eino Kuusi (1880-1936), joka ei myöskään ollut sosialisti, käytti puolestaan käsitettä "kansanluokka". 386 Myös Jaakko Forsman (1867-1946) oli porvarillinen tutkija, joka katsoi, että maaseudulle oli 1900-luvun alussa syntymässä todellinen luokkajako ja myös luokkaristiriita. Hän määritteli yhteiskuntaluokan seuraavasti: "luokat ovat varallisuus- ja sivistyskantansa puolesta toisistaan eroavia, mutta samalla yhteiskunnallisessa suhteessa toisistaan riippuvaisia väestöryhmiä’” ${ }^{387}$

käsityksistä vertaa Jutikkala, Eino. Talonpoika, aatelismies, kruunu. Maapolitiikkaa ja maanomistusoloja Pohjoismaissa 1550-1750. Juva 1983, s.91-92.

384 Gylling 1909 A, s.132.

385 Gebhard, Hannes, Yhteiskuntataloudelliset olot Suomen maalaiskunnissa. Teoksessa Oma Maa 4. Toim. Palmén, E.G. et al., Porvoo 1909, s.8-24.

386 Kuusi, Eino, Työväenkysymys. Teoksessa Oma Maa 5. Toim. Palmén, E.G. et al., Porvoo 1910, s.810-824.

387 Forsman, Jaakko, Mistä syystä sosialismi levisi Suomen maalaisväestön keskuuteen. Helsinki 1912, s.33. Monen muun tavoin Forsman oli lähellä 
Gyllingin käyttämät käsitteet eivät siis poikenneet mitenkään porvarillisten tutkijoiden käsitteistöstä. Tosin porvarillisetkin tutkijat saattoivat hyödyntää Marxin ja muiden sosialismin klassikkojen tulkintoja olematta silti suoranaisesti marxilaisia.

Gylling osoitti, että vielä 1700-luvun puolivälissä Suomen maaseudulla oli lähinnä talollisasutusta. Tuolloin oli ainoastaan vähäistä torppariasutusta sekä vielä vähemmän mäkitupalaisia ja tilatonta väestöä. 1700-luvun jälkipuoli oli voimakkaan kehityksen aikaa, jolloin väkimäärä kasvoi nopeasti. Talollisasutuskin kasvoi mutta hitaammin kuin koko maaseutuväestö, joten torppari-, mäkitupalais- ja tilaton väestö kasvoivat talollisväestöä lukuisimmaksi. 1800-luvulle tultaessa maalaisväestön yhtenäinen luonne oli hävinnyt, kun vallitsevan talollisväestön alapuolelle oli kasvanut uusia nopeasti lisääntyviä väestökerroksia. Gyllingin mukaan kehitys oli samansuuntaista koko Ruotsin valtakunnassa. ${ }^{388}$

Gylling pohjusti tutkimustaan perusteellisella tilastollisella analyysillä. Hän laski tarkkaan torpparien ja osittain muun tilattoman väestön kehityksen. Gylling erotteli torpparit eri ryhmiin sen pohjalta, minkälaisen tilan alaisuudessa he olivat. Lisäksi hän suoritti perinpohjaiset alueelliset laskelmat ja vertailut. Tulokseksi tuli, että torpparilaitoksen muodot olivat varsin erilaisia eri puolilla Suomea. ${ }^{389}$

Voionmaan mukaan Gyllingin tekemä tutkimus oli laaja ja seikkaperäinen esitys Suomen torpparilaitoksesta ja sitä koskevasta lainsäädännöstä. Johdannossa käsiteltiin 1700-lukua aikaisempia torpparioloja, joista ei tuotu esiin mitään uutta, vaikka tehdyistä paikannimitutkimuksista olisi voinut jotain päätellä. Tutkimuksessa valaistiin yleensäkin varsin niukasti Suomen vanhempaa uudisasutusta. Vastaväittäjän mielestä oli epätodennäköistä, että yksityinen takamaiden omistus oli tuolloin niin laajaa ja kollek-

työväenliikettä vielä ennen suurlakkoa, mutta irtaantui siitä sen radikalisoiduttua. Ks. Alapuro - Alestalo 1992, s. 96-97.

388 Gylling 1909 A, s.89-90, 245-247.

389 Gylling 1909 A, esim. s. 72. 
tiivista sekä kruunun omistus niin heikkoa kuin tutkimuksessa oletettiin. ${ }^{390}$

Voionmaa katsoi, että 1600-luvun kehitykseen siirryttäessä esitys oli ansiokas. Tekijä oli julkaissut "yhtä valaisevia kuin harvinaisiakin tietoja kartanoiden torpparitaloudesta tällä uudemman torpparilaitoksen syntymäkaudella”. Itämeren alueen suurtilajärjestelmän vaikutusta Suomen kartanotalous- ja torpparioloihin olisi kuitenkin voinut käsitellä laajemmin. Vastaväittäjä katsoi, ettei tekijän päätarkoitus ollut torpparilaitoksen työ- ja verosuhteiden tai taloudellisen historian tutkiminen. Gylling oli eri mieltä ja kirjoitti marginaaliin, että"tietysti on taloudellisen historiaa".

Tuolloin historiantutkimuksen peruskäsitteet olivat lamprechtilaisen kulttuurihistorian ja modernin valtiollis-polittisen historian kasvavan vaikutuksen takia käymistilassa. Voionmaa ja Gylling ymmärsivät mahdollisesti käsitteen "taloushistoria" eri tavoin. Tämä saattaa selittyä heidän erilaisista tieteellisestä taustastaan käsin. Gylling oli tilastoja paljon käyttävä yhteiskuntatieteilijä, jonka näkemykset perustuivat yhtälttä kansantaloustieteen historialliseen koulukuntaan ja toisaalta marxilaisuuteen. Voionmaa oli puolestaan suomalaisen lamprechtilaisen historiantutkimuksen uranuurtajia, missä tosin myös taloudelliset näkökulmat olivat keskeisiä ${ }^{392}$.

Voionmaa totesi, että teos oli historiallinen tutkimus Suomen torpparilaitoksen kehittymisestä 1700-luvulla. Pohjana oli liitteessä julkaistu aineisto, jonka tekijä on koonnut huolellisesti. Voionmaa huomautti myös, että tekijä oli tilastojen käsittelijänä tarkka ja tunnollinen, vaikka oli tehnyt joitain vähäisiä virheitä. Hän arvosteli muun muassa puutteellista selvitystä veroluetteloiden ja tabelliluetteloiden eroista sekä sitä, ettei tekijä huomauttanut

390 KA, EGK, kansio 1, ote Filosofisen tiedekunnan Historiallis-kielitieteellisen osaston ptk.:sta 6.10.1909 liitteineen.

391 KA, EGK, kansio 1, ote Filosofisen tiedekunnan Historiallis-kielitieteellisen osaston ptk.:sta 6.10.1909 liitteineen.

392 vrt.Tommila 1989, s.135-136,147-149. 
selkeästi hallinto- ja kirkkopitäjien erilaisuudesta. Gylling kirjoitti marginaaliin selvittäneensä molemmat kysymykset. ${ }^{393}$

Voionmaan mielestä oli vaikea tietää, milloin tekijä käytti pitäjää hallinnollisessa ja milloin kirkollisessa mielessä. Tästä johtuen tilastot olivat niin epätarkkoja, että niitä voi vain suurella varovaisuudella käyttää paikallisessa tutkimuksessa. Gylling kirjoitti, että "voi kyllä, kun pitää mielessä, että ne koskevat hallinnollisia pitäjiä". Voionmaa korosti toisaalta, että tutkimus koski koko maata ja virheet hävisivät suuressa mittakaavassa. Suurimpiin piireihin kohdistuva tilasto oli varmalla pohjalla ja maakuntiin kohdistuva vielä varmemmalla. Erityisesti taulukko Torpparit Suomessa 1700-luvun alkupuolella ryhmitettyinä päätilansa kameralisen maaluonnon mukaan ${ }^{394}$ oli monimutkaisen työn tulos, vaikka koskikin vain yhtä vuotta.

Voionmaan mukaan tekijän kuitenkin onnistui luoda selvä kuva 1700-luvun alun torppariasutuksen alueellisesta liikkeestä ja edustavista tyypeistä. Ruotsin vallan loppukauden käsittelyssä oli runsasta tilastollista aineistoa käytetty "kaikella mahdollisella monipuolisuudella". ${ }^{395}$ Voionmaan mukaan kehityksen perimmäiset syyt eli lähinnä tuotantotavan muutokset olivat sivuasioita. Gylling totesi reunamerkinnässä, etteivät tuotantotavan muutokset ole niinkään sivuasioita, vaan niihin viitataan useita kertoja. ${ }^{396}$

Voionmaa tiivisti kaiken kaikkiaan varsin myönteisen arvionsa seuraavasti:

Kokonaisuudessaan on tämä suuri ja etevä ja alallaan ainoa tutkimus kunniaksi tekijälleen sekä arvokas lisä tieteelliseen kirjallisuutemme. Mielestäni täyttää se hyvin ne vaatimukset, joita lisensiaatinarvoa varten kirjoitetulle väitöskirjalle on asetettu... Tekijän

393 KA, EGK, kansio 1, Filosofisen tiedekunnan historiallis-kielitieteellisen osaston ptk. 6.10.1909 liitteineen.

394 Gylling 1909 A, liiteosa s.195-205.

395 KA, EGK, kansio 1, Filosofisen tiedekunnan historiallis-kielitieteellisen osaston ptk. 6.10.1909 liitteineen.

396 KA, EGK, kansio 1, ote Filosofisen tiedekunnan Historiallis-kielitieteellisen osaston ptk.:sta 6.10.1909 liitteineen. 
väitöstilaisuudessa tehtyihin muistutuksiin antamat selitykset todistivat tutkimusaineen perinpohjaista tuntemusta. ${ }^{397}$

Gyllingin lisensiaatinarvo vahvistettiin filosofisen tiedekunnan historiallis-kielitieteellisessä osastossa 6.10.1909. Hänelle myönnettiin noin kuukautta myöhemmin tohtorin arvo. Hänellä oli laudatur maanviljelyksen kansantalous- ja tilastotieteestä sekä approbaturit teoreettisesta filosofiasta ja pohjoismaiden historiasta. ${ }^{398}$

Gyllingin väitöskirjasta tuli perusteos, jota torpparikysymystä myöhemmin tutkineet käyttivät ahkerasti. Viljo Rasilan uraauurtavan teoksessa Suomen torpparikysymys vuoteen 1909 historiallisessa taustoituksessa Gyllingin taulukoilla ja päätelmillä on keskeinen asema. ${ }^{399}$ Arvo M. Soininen käyttää vielä vuonna 1999 julkaistussa artikkelissaan Gyllingin väitöskirjaa lähdemateriaalina. ${ }^{400}$ Gyllingin tutkimukselle on näihin päiviin asti annettu arvoa myös erilaisissa yleisesityksissä. ${ }^{401}$

Gyllingin yritys tuoda uusi näkökulma yhteiskunnalliseen keskusteluun torpparilaitoksesta ei kuitenkaan onnistunut. Hänen väitöskirjansa jäi varsin vähälle huomiolle eikä vastaväittäjä Väinö Voionmaakaan julkaissut lausuntoaan. Voi olla, että poliittiset ryhmät olivat lyöneet kantansa lukkoon niin tiiviisti, ettei uudenlaiselle tarkastelulle ollut enää tilaa.

Poliittinen toiminta vei väitöskirjan jälkeen yhä suuremman osan Gyllingin ajasta, eikä hän tehnyt enää yhtään laajaa tutkimusta. Hän kirjoitti kuitenkin edelleen ahkerasti erilaisia katsauksia ja artikkeleita, joista osalla oli tieteellistä arvoa. Gylling kirjoitti torpparilaitoksesta artikkeleita, joissa historiallinen näkökulma yhdistyi aikakauden ongelmiin toisin kuin puhtaasti tieteellises-

397 KA, EGK, kansio 1, ote Filosofisen tiedekunnan Historiallis-kielitieteellisen osaston ptk.:sta 6.10.1909 liitteineen.

398 KA, EGK, kansio 1, ote Filosofisen tiedekunnan Historiallis-kielitieteellisen osaston ptk.:sta 6.10.1909 liitteineen.

399 Rasila 1961, s.15-27.

400 Soininen 1999. s.25-42.

401 Ks. esim. Haatanen 1992, s.155. 
sä tarkoituksessa tehdyssä väitöskirjassa. Näissä artikkeleissa hän myös jatkoi käsittelyä aina 1900-luvun alkuun saakka. Samalla hän selvensi suhdettaan marxilaiseen historianfilosofiseen teoriaan ja erityisesti "feodalismi" käsitteeseen. Käsite "feodaalinen" syntyi Ranskan läänitysoikeutta käsitelleiden juristien toimesta jo 1500-luvulla. Ensiksi "feodalismi” oli puhtaasti juridisesti määritelty ilmiö, jolla tarkoitettiin Reinin ja Loiren välillä 800-luvulta 1200-luvulle vallinnutta roomalaiselle oikeudelle tuntematonta oikeudellista instituutiota, johon kytkeytyivät vasallisopimus ja läänityslaitos. Vähitellen käsite siirtyi historiantutkimukseen ja lopulta poliittiseen teoriaan. Ensin sillä tarkoitettiin tietynlaista hallitusmuotoa, ja lopulta erityistä astetta inhimillisen sivilisaation kehityksessä. 1800-luvun Ranskassa ja Saksassa keskusteltiin paljon feodalismin merkityksestä. Karl Marx esitti myös aiheesta tunnetun tulkintansa, jossa hän totesi feodalismin edeltäneen porvarillista yhteiskuntaa. ${ }^{402}$

Gylling kirjoitti väitöstilaisuuden jälkeen artikkelin, jossa hän käsitteli väitöskirjansa taustoja. Hänen mukaansa polttavaa torpparikysymystä oli valaistu monin tavoin nykyhetkestä käsin, muttei oltu kiinnitetty juuri mitään huomiota sen historiaan. Hän halusi väitöskirjallaan tuoda lisävalaistusta ilmiön historialliseen kehitykseen ja syihin. Gylling vertasi suomalaista maanvuokralaitosta eurooppalaiseen feodalistiseen järjestelmään. Suomessa ja Ruotsissa torppari oli vajoamassa maaorjuuteen samalla tavalla kuin talonpoika Euroopassa. Näin ei kuitenkaan tapahtunut, vaan torppariluokka kehittyi henkilökohtaisesti vapaaksi vuokramiesluokaksi. Maanvuokralaitos edusti feodalistista kautta Suomessa, vaikkakin se kehittyi vasta kun muualla Euroopassa tämä kausi alkoi jo väistyä. ${ }^{403}$

402 Hietaniemi, Tapani, Mistä feodalismiproblematiikka sai alkunsa? Teoksessa Feodalismi. Toim. Hietaniemi, Tapani et al. Tampere 1997, s.25-26, 33-35. Marx esitti tästä kuitenkin useita vaihtoehtoisia malleja, eikä ylipäätään kiinnittänyt asiaan läheskään niin paljon huomiota kuin ajankohtaisempiin kysymyksiin. Neuvostoliiton marxilais-leniniläinen tutkimus teki kuitenkin Marxin tulkinnasta dogmin, josta on myöhemmin yleisesti luovuttu.

403 Gylling, Edvard, Suomen torpparilaitoksen kehityksen pääpiirteet. Työmies 2.6.1909 (E). 
Gylling käsitteli feodalismia useissa kirjoituksissaan seuraavan parin vuoden aikana. Gylling korosti torppariluokan syntymistä 1600-luvulla sekä nopeaa kasvua 1700- ja 1800-luvuilla. Hän totesi, että maanvuokralaitoksen kehitys vauhdittui Suomessa samaan aikaan kuin samoja piirteitä sisältänyt feodaalilaitos alkoi KeskiEuroopassa jo väistyä. ${ }^{404}$ Tämä johtui siitä, että aateli ja talonpojat huomasivat 1700-luvulla etujensa yhteisyyden maanomistajina, minkä jälkeen se ei ollut unohtunut. ${ }^{405}$

Kaiken kaikkiaan Gyllingin mukaan luontaistalouden vallitessa oli ollut voimakas maatyöväen tarve, joka antoi maanvuokralaitokselle hyvät kehitysedellytykset. Moderni kapitalistinen vaihdantatalous perustui kuitenkin rahatalouteen. Kun kapitalisti sai halpaa työvoimaa, lisäarvo oli suuri ja pääoma kasautui. 1800-luvun loppupuolella Suomessa alkoi kapitalismin läpimurto, mikä merkitsi maanvuokraajalaitoksen taantumista. Kapitalistinen talous pyrki saamaan palkkatyöväkeä, joten "feodalinen torpparilaitos" ei soveltunut uuteen järjestelmään. Näin vanhan ja uuden ristiriita kärjistyi jatkuvasti. Tämä tilanne sai aikaan maanvuokraajien aseman huonontumisen, mikä näkyi muun muassa häädöissä ja lakoissa. ${ }^{406}$

Gyllingin näkemykset pohjautuivat varsin pitkälle marxilaiseen teoriaan, minkä mukaan uusien tuotantomuotojen ja niistä jälkeen jääneiden tuotantosuhteiden ristiriita johtaa kriisiin ja lopulta uuteen järjestelmään. Näin ollen kapitalismi syrjäytti feodalismin, mutta joutuu aikanaan väistymään sosialismin tieltä. Toisaalta Gylling ei ollut tässäkään asiassa kovin dogmaattinen, vaan ennemmin empiirikko. Pian näiden artikkeleiden kirjoittamisen jälkeen Gylling nimittäin luennoi puolueopistossa Suomen

404 Esim. Gylling, Edvard, Hufvuddragen af torpareklassens utveckling i Finland. Folktribunen 12/1909 (B), s.292-298.

405 Gylling, Edvard, Milloin talolliset saivat oikeuden torpparin verottamiseen. Uuden ajan kynnyksellä, Suomen työväen joulualbumi XIII, 1910 (B), s.29.

406 Gylling, Edvard, Katsaus torpparilaitoksen kehitykseen Suomessa. Työväen Kalenteri III/1910, 1909 (C), s.132-133, 138. 
yhteiskuntataloudellisesta kehityksestä ja totesi, ettei Suomessa ollut esiintynyt varsinaista feodalismia. ${ }^{407}$

Vuonna 1910 kirjoittamassa artikkelissaan Gylling jakoi vuokratilat herraskartanoiden alaisiin ja talonpoikaistyyppisiin. Vuokraviljelijällä oli jälkimmäisessä ainakin oikeudellisessa mielessä parempi asema. Edellisessä suurviljelyksen edut olivat määräävät, minkä vuoksi vuokraviljelijän olot olivat huonommat. ${ }^{408}$ Gylling antoi tästä tilanteessa varsin raadollisen kuvan:

Tavallisesti ilman kirjallista kontrahtia, halliten vuokratilaansa vain irti sanomisen varassa vuodesta toiseen, on herraskartanon torppari, vaikka hänen torppansa viljelykset ovat laajatkin, joutunut kokonaan maanomistajasta riippuvaiseen asemaan.... Torppa, johon hän on kiinnittänyt kaikki työnsä ja varansa, sitoo hänet turpeeseen, joten hänen liikuntovapautensa on vähempi kuin varsinaisen maatyöväen. ${ }^{409}$

Gyllingin torpparilaitoksen kehityksestä antamaa kuvaa voidaan verrata nykypäivänä vallitsevaan käsitykseen. Arvo M. Soinisen mukaan se oli aluksi edistyksellinen ratkaistessaan yhteiskunnallisia ongelmia ja vakiintui vähitellen osaksi suomalaista yhteiskuntaa. Torpparilaitos ei kuitenkaan kyennyt mukautumaan 1800-luvun puolivälin jälkeen alkaneeseen maataloudelliseen ja yhteiskunnalliseen kehitykseen. 1900-luvun alussa se oli jo vanhentunut instituutio, joka oli kehityksen jarruna tuomittu häviämään. Soininen katsoo, että torppareiden asema oli alun alkaen kohtuullisen hyvä, mutta 1800-luvun lopulla heidän asemansa heikkeni taloudellisesti ja tuli epävarmemmaksi. Taustalla oli

407 TA, Puolueopisto 1910-1913. Useimmat tutkijat ovat nykyään samaa mieltä. Jouko Nurmiainen ja Mikko Piippo esittävät suomalaisesta feodalismista katsauksen ja päätyvät siihen tulokseen, että käsitteen käyttö Suomen historiassa on erittäin ongelmallista. Ks. tarkemmin Nurmiainen, Jouko - Piippo, Mikko, Suomalainen historiankirjoitus ja feodalismi. Teoksessa Feodalismi. Toim. Hietaniemi, Tapani et al., Tampere 1997, s.309-328.

408 Gylling, Edvard, Maanvuokraolot. Yhteiskunnallinen Käsikirja, 1910 (C), s.258.

409 Gylling 1910 C, s.258. 
ennen kaikkea muutokset metsätaloudessa ja kasvinviljelyssä. ${ }^{410}$ Tämä vastaa pääpiirteittäin Gyllingin asiasta antamaa yleiskuvaa, joskin ilman marxilaissävytteistä käsitteistöä ja kannanottoja torppareiden puolesta.

410 Soininen 1999, s.25-36. 


\title{
5. Sosialidemokraattien maatalouspolitiikan linjanvetäjä
}

\author{
Uuden maanvuokralain hyväksyminen
}

Vuonna 1902 säädettiin maanvuokralaki. Sen mukaan pisimmäksi sallituksi vuokrakaudeksi jäi edelleen 50 vuotta ilman perinnöllistä vuokra-oikeutta ja sopimuskauden alarajaa, mikä tulkittiin käytännössä vähintään yhdeksi vuodeksi. Vuotuinen vuokra maksettiin rahassa, työssä tai luonnontuotteina. Työpäivät oli jaettava tasaisesti ympäri vuotta, ellei sopimuksessa toisin mainittu. Työpäivän pituudesta ei määrätty mitään. Maanvuokraajan piti saada tilan perusparannuksista korvaus, jos ne oli tehty vuokranantajan luvalla. Tämän asian merkitystä vähensi se, että korvauksen määräsi kahdenkeskinen katselmus, missä tilanomistajalla oli vahvempi asema. Maanvuokraaja voi irtisanoutua kesken vuokrakauden ja hänet voitiin irtisanoa, jos hän rikkoi sopimusta tai ei totellut maanomistajaa. ${ }^{411}$

Maanvuokraajien - ja laajemminkin tilattoman väestön huono asema - oli yksi suurimmista yhteiskunnallisista epäkohdista, joten se oli demokraattisesti valittujen valtiopäivien tärkeimpiä kysymyksiä. Ensimmäisten valtiopäivien aikana tosin Suomalainen puolue, Nuorsuomalainen puolue ja Ruotsalainen Kansanpuolue korostivat kansallisia näkökulmia enemmän kuin yhteiskunnallisia ongelmia. SDP ja Maalaisliitto toivat kuitenkin sosiaaliset kysymykset vahvasti esille ja lähtivät parantamaan edustamiensa

411 Rasila 1961, s.58, 203-205. 
kansanryhmien asemaa. Vähitellen näiden kahden puolueen kannatus vahvistuikin ja kansanedustajien määrä nousi. ${ }^{412}$

Uuden maanvuokralain tarve nousi valtiopäivillä vahvasti esiin, varsinkin kun samaan aikaan oli menossa torpparien häätöjä. Vuoden 1907 valtiopäivillä tuli lakia koskien käsittelyyn senaatin esityksen lisäksi lukuisia edustajien aloitteita. Ne kaikki perustuivat vuonna 1906 asetetun komitean suorittamiin valmisteluihin. Asiaa ei kuitenkaan saatu näillä valtiopäivillä valmiiksi vaan se jäi keskeneräisenä suureen valiokuntaan. Maanvuokralain suurin erimielisyys liittyi ns. takautuvaan lakiosaan, joka koski uuden lain soveltamista aikaisemmin tehtyihin vuokrasopimuksiin. Sosialidemokraattisen eduskuntaryhmän mielestä oli kaikille niille, jotka vuoden 1902 maanvuokralain perusteella oli häädetty vuokratiloiltaan, palautettava heidän oikeutensa tai muuten korvattava heidän menetyksensä. Porvarilliset ryhmät olivat myös taipumassa jonkinlaiseen takautuvaan lainsäädäntöön, vaikkakin eri painotuksin. Vuoden 1908 ensimmäisille valtiopäiville annetun hallituksen esityksen tie pysähtyi eduskunnan tultua hajotetuksi. ${ }^{413}$

Uusi maanvuokralaki oli siis vielä aivan alkutekijöissään, kun Gylling tuli kansanedustajana ensimmäisille valtiopäivilleen vuonna 1908. Vuoden 1907 valtiopäivillä hän oli tosin toiminut maatalousvaliokunnan sihteerinä, joten hänellä oli kokemusta valtiopäivien toiminnasta. ${ }^{414}$ Gylling valittiin heti keskeiseen suureen valiokuntaan, jonka jäsen hän oli myös vuoden 1909 toisilla valtiopäivillä ja vuoden 1913 valtiopäivillä. Hänellä oli lisäksi runsaasti muita valiokuntatehtäviä. Maatalouskysymyksen kannalta tärkeässä maatalousvaliokunnassa hän oli jäsenenä vuoden 1909 toisilla valtiopäivillä ja lisäksi kaksi kertaa varajäsenenä. ${ }^{415}$

Gylling keskittyi kansanedustajana ennen kaikkea maatalouspolitiikkaan ja valtion varojen hoitamiseen. Gylling oli edustajana kuusilla valtiopäivillä, joissa hän käytti yhteensä 108 puheenvuo-

412 Vares 2006, 19-46.

413 Tuominen 1958, s. 336-339; Rasila 1961, s.391-407.

414 Rasila 1961, s.395.

415 Valtiopäiväpöytäkirjojen lopussa olevat luettelot eduskunnan jäsenten toiminnasta vuosilta 1908-1914. 
roa. Niistä varsinaisia maatalouden kysymyksiä koski kolmisen kymmentä sekä valtion varojen hoitoa parisen kymmentä. Loput lausunnot jakaantuvat melko tasaisesti useiden asioiden kesken. ${ }^{416}$

Vuoden 1908 toisilla valtiopäivillä maanvuokralaki tuli jälleen esille vanhasuomalaisten esitysehdotuksena ja hallituksen esityksenä. Lopullinen suuren valiokunnan mietintö laadittiin hallituksen esityksen pohjalle. Se oli pääpiirteittäin saman sisältöinen kuin vuoden 1907 valtiopäivillä syntynyt vastaava mietintö. Olennainen ero oli siinä, että vuokrakirja ehdotettiin nyt rekisteröitäväksi kihlakunnanoikeudessa, kun aiemmin se oli ehdotettu tehtävän vuokralautakunnassa. Suurin kiista liittyi kuitenkin jälleen takautuvaan lakiosaan, joka koski uuden lain soveltamista aikaisemmin tehtyihin vuokrasopimuksiin. ${ }^{417}$

Suuren valiokunnan mietintö tuli eduskunnan käsittelyyn. Keskustelussa aktiivisin sosialidemokraatti oli Sulo Wuolijoki, jonka tyyli oli varsin värikäs ja hyökkäävä. Gylling käytti myös useita puheenvuoroja, mutta Wuolijokea maltillisempaan ja asiallisempaan sävyyn. Sulo Wuolijoen ja Suomalaisen Puolueen Hannes Gebhardin välillä käytiin jo kysymyksen ensimmäisessä käsittelyssä voimakassanainen väittely siitä, kumpi ryhmä ajoi todellisuudessa maanvuokraajien aseman parantamista. Esityksen tullessa toiseen käsittelyyn Gylling puolestaan vastusti vanhasuomalaisen O. A. Hainarin muutosehdotusta, joka koski tosin vain työsuunnitelmaa. ${ }^{418}$ Näillä kannanotoilla on kiinnostavaa kuriositeettiarvoa,

416 Laskelmat perustuvat valtiopäiväpöytäkirjojen lopussa oleviin luetteloihin eduskunnan jäsenten toiminnasta. Puheenvuorojen jaottelu eri aiheisiin ei ole yksiselitteistä, koska aihepiirien rajat eivät aina ole selkeitä. Lisäksi muutamat lausunnoista koskivat asioiden käsittelyjärjestystä tai muita muodollisia tekijöitä. Nämä asiat eivät kuitenkaan muuta kokonaiskuvaa olennaisesti.

417 Tuominen 1958, s.339

418 TA, SDP:n eduskuntaryhmän ptk.:t 1907-1914; 1908 II VP, ptk. I, s.500-525, ptk. II, s.1161-1168. Eduskunnan toimintaa valaisevien virallisten asiakirjojen sisällöstä tarkemmin Salervo, Olavi, Eduskunnan toimintaa valaisevat viralliset asiakirjat. Teoksessa Suomen kansanedustuslaitoksen historia X. Toim. Salervo, Olavi et al. Helsinki 1977, s.24-33. 
sillä Gebhard oli ollut sekä Sulo Wuolijoen että Gyllingin tärkein akateeminen opettaja. Hainari puolestaan oli heidän lyseoaikainen historianopettajansa, jolla oli suuri merkitys molempien ajattelun kehittymiseen.

Kun ehdotusta maanvuokralaiksi käsiteltiin vuoden 1908 valtiopäivien toisessa käsittelyssä yksityiskohtaisesti, Gylling otti kantaa joihinkin kohtiin. Kolmannessa pykälässä katsottiin, että toivottavin vuokranmaksuväline olisi raha, mutta vuokrasopimuksessa se voitiin määrätä maksettavaksi myös luonnontuotteina tai päivätöinä. Gylling totesi, että rahavuokraan siirtyminen oli yksi tärkeimmistä asioista maanvuokraolojen uudistamisessa. Sosialidemokraattien mielestä työvuokra pitäisikin kokonaan kieltää feodaalisena jäänteenä. Tämä ajatus hylättiin porvarillisten puolueiden edustajien toimesta. ${ }^{419}$

Gylling käytti jälleen puheenvuoron, kun käsiteltiin päivätöitä. Vanhasuomalaisten edustaja H. G. Paloheimo (1864-1919, vuoteen 1906 Brander) vastusti ehdotusta, jonka mukaan päivätöistä olisi ilmoitettava vuokramiehelle vuorokautta ennen. Hänen mielestään "hyvissä ajoin" edellisenä päivänä olisi riittänyt. Gylling vastasi tähän, että maanomistajien taholta oli haluttu säilyttää päivätyöjärjestelmä, joten sen heikkoudet tulivat luonnollisesti heidän kannettavikseen. Tällä kertaa Gyllingin kanta voitti, sillä alkuperäinen ehdotus meni muuttumattomana läpi. ${ }^{420}$

Maanvuokralakiehdotuksen 21. pykälästä syntyi voimakassanainen keskustelu. Pykälässä todettiin, että jos vuokrasopimuksessa määrättiin osa tai koko vuokra suoritettavaksi luonnontuotteissa tai päivätöissä, sekä maanomistajalla että maanvuokraajalla oli mahdollisuus muuttaa se suoritettavaksi ainoastaan rahassa. ${ }^{421}$ Gebhard kiitteli sitä, että kaikki ryhmät kannattivat tätä radikaalia uudistusta. Vanhasuomalaiset kuitenkin esittivät, että rahamaksuun siirtymiselle vaadittaisiin vuokralautakunnan suostumus, koska monet maanvuokraajat eivät halunneet siirtyä rahamak-

4191908 II VP, ptk. 3, s.1326-1327; 1909 Asetuskokoelma, asetus n:o 12, 3. 4201908 II VP, ptk.3, s.1349-1351; 1909 Asetuskokoelma, asetus n:o 12, 20. 4211909 Asetuskokoelma, asetus n:o 12, 21. 
suun. Muussa tapauksessa saattaisi käydä jopa siten, että maanvuokraaja kykenemättömänä rahamaksuun joutuisi lähtemään vuokratilaltaan. ${ }^{422}$ Tähän Gylling vastasi työvuokran aiheuttava vuokramiehelle usein lisämenoja, kuten hevosen ja rengin hankkimisen. Rahamaksuun siirtymisen jälkeen nämä ylimääräiset menot jäisivät pois, minkä lisäksi maanvuokraajalla olisi aikaa mennä ansiotyöhön muualle, esimerkiksi metsätöihin. Gylling katsoi, että jos Gebhardin ajattelu pitäisi paikkansa, johdonmukaisinta olisi kieltää maanomistajalta mahdollisuus siirtyä rahamaksuun mutta jättää tämä oikeus maanvuokraajalle. Gylling katsoi, että ajaessaan pykälän muuttamista vanhasuomalaiset ajoivat todellisuudessa maanomistajan etuja ja taustalla oli halu säilyttää maanvuokraajalaitos ennallaan. Hänen mielestään työvuokrajärjestelmä oli maanvuokralaitoksen taantumuksellisin asia, joka pakotti sekä maanomistajan että maanvuokraajan konservatiivisiin ratkaisuihin, jolloin maanviljelyksen edistyminen vaarantui. Gebhard totesi, etteivät monet maanvuokraajat joutuneet hankkimaan uutta hevosta päivätöitä varten eikä joka paikassa ole tarjolla metsätöitä. Näin ollen rahamaksuun siirtyminen ei ollut aina maanvuokraajille edullista. Gebhard ja häntä tukenut vanhasuomalainen Paloheimo eivät kuitenkaan esittäneet äänestystä asiasta, koska he pitivät sitä turhana. Pykälä hyväksyttiinkin sellaisenaan. ${ }^{423}$

Gylling painotti sitä, että lainsäädännön pitäisi tukea taloudellista edistystä ja tuettava uusien viljelysmuotojen käyttöönottoa, kun se on järkevää. Hän kannattikin suuren valiokunnan ehdotusta, jonka mukaan maanvuokraaja saa korvauksen aiheuttamastaan tilan arvon noususta. Tämä kohta hyväksyttiin muutoksitta. Ehdotuksen mukaan maanomistaja ei joutunut suorittamaan korvausta vuokramiehen tekemistä parannuksista, mikäli sopimusta jatkettiin entisillä ehdoilla vuokralautakunnan määräämän ajan. Sosialidemokraatit ajoivat pykälän poistamista. Gylling katsoi, että sen perusteella maanomistaja voi sitoa vuokramiehen turpee-

4221908 II VP, ptk. 3, s.1366-1368.

4231908 II VP, ptk. 3, s.1369-1376. 
seen pitkäksi ajaksi. Hänen mukaansa taustalla oli vanhasuomalaisten pyrkimys pitää työväenluokka mahdollisimman edullisesti maanviljelijän käytettävissä. SDP:n vastustuksesta huolimatta pykälä hyväksyttiin. ${ }^{424}$

Yksi eduskunnan käsittelemistä kiistakysymyksistä koski vuokraoikeuden siirtämistä. Voimassa olleen maanvuokralain mukaan vuokraoikeuden siirtämiseen toiselle maanvuokraajalle tarvittiin maanomistajan lupa, mutta sen jälkeen siirtosumma oli vapaasti sovittavissa. Osassa maata vuokrasopimuksissa oli jopa säädetty siten, että siirto voitiin toteuttaa ilman maanomistajan lupaa. Suuren valiokunnan ehdotuksen mukaan siirto voitaisiin toteuttaa ainoastaan määrätyllä summalla. Se vastaisi korvausta, jonka maanvuokraaja olisi oikeutettu saamaan lähtiessään pois tilalta. Gylling vastusti muutosta, koska siinä huononnettiin maanvuokraajan asemaa, varsinkin kun ehdotukselle haluttiin antaa taannehtiva luonne. Hän ehdotti, että siirtosumma riippuisi edelleen vanhan ja uuden maanvuokraajan välisestä sopimuksesta. Sulo Wuolijoki kannatti Gyllingin ehdotusta ja toivoi, että Maalaisliiton edustajat ja eräät muiden puolueiden edustajat äänestäisivät kysymyksessä omantuntonsa eikä ryhmäkurin mukaan. Muutoksen kannattajat puolestaan katsoivat, että jos maanvuokraaja saisi ottaa siirtosummana niin paljon kuin voi, hän saisi ansiotontakin tuloa. Gyllingin ehdotus hävisi lopulta numeroin 99-94, koska porvarillisten puolueiden edustajat eivät kannattaneet sitä riittävän laajasti. ${ }^{425}$

Monien yksityiskohtaisten keskustelujen ja äänestysten jälkeen eduskunta hyväksyi lokakuussa 1908 uuden maanvuokralain eli asetuksen torppien, lampuotitilojen ja mäkitupien vuokraehdoista. Maanvuokralaki oli varsin laaja: se sisälsi yhteensä 82 pykälää. Asian laadun vuoksi se ei kuitenkaan voinut olla erityisen yksityiskohtainen vaan esimerkiksi metsänkäytön osalta se jätti käyttöoikeuden määriteltäväksi sopimuksessa. Vuokrasopimus määrättiin tehtäväksi vähintään 50 vuodeksi ja enintään sadaksi vuodeksi. Vuokra suoritettiin rahassa, eikä sen suuruutta voitu muuttaa

4241908 II VP, ptk. 3, s. 1386-1390, 1604; 1909 Asetuskokoelma, asetus n:o 12,20 .

4251908 II VP, ptk.3., s. 1604-1612. 
kesken vuokrakauden. Erityisesti sovittaessa sen sai kuitenkin maksaa päivätöinä, joiden hinta määräytyi paikkakunnalla käyvän hinnan mukaan. Vuokrasopimus oli tehtävä kirjallisesti. Eräs asetuksen keskeisimmästä kohdista oli vuokrasuhteiden alistaminen erityisen vuokralautakunnan valvontaan. Jokaisessa kunnassa oli oltava vähintään yksi vuokralautakunta, johon maanomistajat ja maanvuokraajat valitsivat yhtä monta edustajaa. Jäsenet valitsivat ulkopuolelta puheenjohtajan. Jos he eivät saaneet ratkaisua aikaan, kihlakunnanoikeus määräsi puheenjohtajan. Koska molemmilla osapuolilla oli yhtä monta jäsentä, hänen äänensä oli usein määräävä. Lautakunnan päätös oli lopullinen, josta ei voinut normaalitapauksessa valittaa. ${ }^{426}$

Maanvuokralakia sovellettiin aikaisemmin solmittuihin vuokrasuhteisiin siten, että vuokra-aika pidentyi vähintään seitsemällä vuodella. Viljo Rasilan mukaan toimenpiteen taustalla oli vuokralakiparannusten riittämättömyyden tajuaminen. Jäädyttämällä vuokrasuhteet pyrittiin saamaan riittävästi harkinta-aikaa ongelman ratkaisemista varten. Tuloksena oli kuitenkin se, että maaliskuussa 1916 kodin ja peltotilkun menettäminen uhkasi samanaikaisesti kymmeniä tuhansia maanvuokraajia perheineen. ${ }^{427}$

Taannehtiva asetus ei vakuuttanut vuokrasuhteita täysin irtisanomattomiksi, vaan se ainoastaan kumosi vuoden 1902 irtisanomispykälän sekä ulotti uuden maanvuokra-asetuksen irtisanomista ja vuokrasuhteen lopettamista koskevat kohdat myös aikaisemmin tehtyihin sopimuksiin. Ennen vuotta 1916 olikin

4261909 Asetuskokoelma, asetus n:o 12; vrt. Rasila 1970, s.20-21. Ruotsissa oli annettu maanvuokralaki kaksi vuotta aiemmin, vuonna 1907. Suomalaisessa keskustelussa ei juuri viitattu Ruotsin tilanteeseen tai tähän lakiin, todennäköisesti siksi, että luontevaa vertailupohjaa e i ollut. Ruotsissa torppareita oli suhteellisesti selvästi vähemmän kuin Suomessa, ja siellä rahavuokra oli yleistynyt jo huomattavasti aiemmin. Ks. Ruotsin kehityksestä Morell, Mats, Jordbroket i industrisamhället 1870-1945. Det svenska jordbrukets historia 4. Red. Myrdal, Janken et al. Borås 2001, s. 63-72, 76-77.

427 Rasila 1970, s.19-26. 
runsaasti tapauksia, joissa entinen sopimus vaihdettiin uuteen ja joskus maanvuokraaja luopui vapaaehtoisesti vuokratilasta. ${ }^{428}$

Kaiken kaikkiaan uusi maanvuokralaki oli kompromissi, johon mikään ryhmittymä ei ollut täysin tyytyväinen. Oikeiston mukaan se sorti omistusoikeuden ikuisuuden periaatetta vastaan, vasemmiston mielestä tilanne säilyi melkein yhtä huonona kuin ennenkin ja keskustan mielestä asetus oli osittain jopa vahingollinen. Puolueista se vastasi kuitenkin lähinnä vanhasuomalaisten ja maalaisliiton kantoja. ${ }^{429}$

Gyllingin suhtautuminen maanvuokralakiin oli myös varsin kaksijakoinen. Hän myönsi sen tuoneen parannuksia, mutta katsoi ne kuitenkin riittämättömiksi. Hän kirjoittikin, että laki oli syntynyt porvarillisten eduskuntaryhmien kompromissin tuloksena ja "sosialidemokratian peikon" pelottamana. Hänen mukaansa vanhentuneen talousmuodon säilyminen orjuutti vuokramiehiä ja heikensi taloudellista edistystä estämällä uusien viljelystapojen ottamisen käyttöön. Gyllingin mielestä uudessa maanvuokralaissa myönteistä oli se, että laki pidensi kaikkien vuokramiesten sopimusta vähintään seitsemällä vuodella ja vähensi maanomistajan mielivaltaista häätöoikeutta. Lisäksi maanvuokraajalle määrättiin korvaus viljelysparannuksista ja rakentamistaan tarpeellisista rakennuksista. Maanvuokraaja sai myös hoitaa tilansa viljelyksiä oman harkintansa mukaan eikä vuokranantaja voinut estää viljelysparannusten käyttöön ottoa. Myönteinen muutos oli myös se, että maanvuokraajalle annettiin mahdollisuus vapautua "orjuuttavasta ja rasittavasta" työverosta ja suorittaa maksunsa rahassa. ${ }^{430}$

Gylling löysi uudesta maanvuokralaista paljon myös kielteisiä asioita. Siinä turvattiin maanvuokraajien asema vain verrattain

428 Rasila 1970, s.27-29.

429 Jutikkala, Eino, Suomen talonpojan historia. 2. uudistettu painos. Helsinki 1958, s.377; Rasila 1961, s.447; Kaikki vanhasuomalaisetkaan eivät tukeneet asetuksen taannehtivuutta, sillä ainakin Malmivaara, Lipponen ja Warvikko vastustivat jatkoaikaa, koska ei ollut maanomistajien etujen mukaista jatkaa nautintaoikeutta ilman uusia verojärjestelyjä. Ks. tarkemmin LeinoKaukiainen 1994, s.173.

430 Gylling, Edvard, Eduskunnan hyväksymä asetus maanvuokrasta, SosA 4445/1908 (E), s.225-226. 
lyhyeksi ajaksi eikä säädetty liian suurten vuokramaksujen alentamista. Gylling tulkitsi, että laissa oli jäljellä osia "feodaalisesta holhontavallasta", joka esti vuokramiehen toimintavapautta. Lakiin jätettiin useita "porvarillisia takaportteja", joissa mainittiin "jollei toisin ole sovittu". Uusi maanvuokralaki voikin olla vain ensimmäinen askel, jota perinpohjaisemmat muutokset lähitulevaisuudessa seuraavat. ${ }^{431}$

Gylling pelkäsi, että monet maanomistajat häätäisivät vuokralaisiaan ennen uuden lain astumista voimaan. Hän perusteli tätä vertaamalla tilannetta vuonna 1904 voimaan astuneen maanvuokralain aiheuttamiin reaktioihin. Vuonna 1903 eli vuosi ennen lakia häätöjä oli lähes kaksi kertaa enemmän kuin seuraavana vuonna, mikä viittasi lain saaneen maanomistajat entistä häätöhaluisemmaksi. ${ }^{432}$

Uuden maanvuokralain oli tarkoitus astua voimaan viimeistään 14.3.1909, jolloin useita maanvuokraajia uhkasi irtisanominen. Nikolai II vahvisti asetuksen vasta kaksi päivää ennen tätä. Lisäksi siihen oli lisätty johdanto, jonka mukaan hajotetun eduskunnan tekemää asetusta ei olisi pitänyt lainkaan esittää keisarille, mutta että hän nyt poikkeuksellisesti vahvisti sen Suomen köyhimpien kansanluokkien aseman parantamiseksi. Ongelmallista oli se, että tätä voitaisiin pitää perustuslakitulkintana. Sosialidemokraattien parissa syntyi kaksi linjaa, jotka eivät olleet millään tavoin aiempien jaottelujen mukaisia. Kuusisen ja Yrjö Mäkelinin (1875-1923) johtama puoli näki taustalla porvarillisen senaatin pyrkimyksen turvata maanomistajien edut, jolloin koko perustuslakikiista oli toissijainen tekijä. Voimakkaimmin tätä linjaa vastaan polemisoi Väinö Tanner, kun taas siltasaarelaisten johtohahmo Edvard Valpas omaksui varovaisen taktiikan. Kysymyksestä käytiin ankaraa kädenvääntöä sosialidemokraattisessa lehdistössä. ${ }^{43}$ Gylling ei ottanut asiaan kantaa.

431 Gylling 1908 E, s.227.

432 Gylling 1908 B, s.3-4.

433 Heikkilä, Jouko, Kansallista luokkapolitiikkaa. Sosiaalidemokraatit ja Suomen autonomian puolustus 1905-1917. Historiallisia Tutkimuksia 168. Helsinki 1993, s.111-116. Heikkilän mukaan maanvuokra-asetuksen julkaise- 
Senaatti palautti asetuksen Pietariin. Se julkaistiin vasta sitten, kun venäläiset olivat vakuuttaneet, ettei johdantoa pidetä perustuslaintulkintana. Asetus julkaistiin tämän viivytyksen takia vasta 30.3.1909 eli yli kaksi viikkoa myöhässä. Tämän kahden viikon aikana lukuisa joukko maanvuokraajia joutui vaille eduskunnan ajattelemaa lainturvaa. Tuolloin jotkut maanomistajat hääsivät maanvuokraajansa, joskin häätöjä oli ilmeisesti melko vähän. ${ }^{434}$

Sosialidemokraatit toivat vuoden 1909 valtiopäiville anomusehdotuksen, missä anottiin korvauksia häädetyille maanvuokraajille. Anomuksen allekirjoittajina olivat Edvard Gylling ja Evert Hokkanen (1864-1918). Sen mukaan kohtuullisinta olisi vaatia korvaukset häädöt suorittaneilta maanomistajilta, mutta koska tämä veisi runsaasti aikaa, ne voitaisiin maksaa valtion varoista. Korvauksiin esitettiin varattavaksi 300000 markkaa. ${ }^{435}$ Anomusehdotus tuli maatalousvaliokunnassa käsiteltäväksi lokakuussa 1909, jolloin sen porvarilliset jäsenet esittivät anomuksen hylkäämistä, koska ei ollut näyttöä häädöistä. Sosialidemokraatit vaativat, että asiasta olisi tehtävä tästä huolimatta periaatepäätös. Maatalousvaliokunta ei ennättänyt käsitellä ehdotusta ennen valtiopäivien päättymistä. Sosialidemokraatit uudistivat anomusehdotuksen jokaisilla valtiopäivillä, mutta vasta vuonna 1912 maatalousvaliokunta sai asiaa koskevan mietinnön valmiiksi. Ehdotus hävisi valiokunnassa vanhasuomalaisten esitykselle, jonka mukaan häädetyillä maanvuokraajilla oli oikeus anoa korvausta senaatilta ja jos he olivat kärsineet suurta vahinkoa, valtion olisi korvattava heille. ${ }^{436}$

Maatalouden kehityksen kokonaisproblematiikkaan liittyi myös metsäpolitiikka, mihin Gylling otti myös voimakkaasti kantaa. Hän kirjoitti aiheesta Työmiehessä vuonna 1908 ja korosti, että metsäkysymys oli tullut entistä tärkeämmäksi. Tähän oli kaksi syytä: ensinnäkin puun hinta oli kohonnut niin korkealle, että sii-

mista ajaneen puolen toiminta merkitsi puoluetaktikoinnin huipentumaa Venäjän-politiikan alueella.

434 Rasila 1970, s.36-37.

4351909 AK, anomusehdotus n:o 125.

436 Rasila 1970, s.37-38. 
tä oli tullut "uusi riistämiskysymys" ja toiseksi kunnollinen puuaines uhkasi loppua monilta seuduilta, koska talolliset olivat hoitaneet metsänsä huonosti ja myyneet sitä liikaa. Gylling katsoi, ettei metsänkasvatus sovi yksityisille toimijoille, koska ne hädän tullen kaatavat kaikki puunsa. Tämän estämiseksi pitäisi säätää laki, joka kieltäisi liian pienten puiden myymisen ja asettaisi metsänhoitoa valvomaan metsäntarkastuslautakunnan. Pitkällä aikavälillä Gyllingin ratkaisu oli vielä radikaalimpi. Metsänomistajien pitäisi muodostaa metsäyhdyskuntia, jotka järjestäisivät metsänhoidon ja turvaisivat alueensa polttopuun saannin. Niiden myymistä metsistä puolet menisi yhdyskunnalle itselleen ja puolet valtiolle. Gyllingin mukaan tämä varmistaisi metsän järkevän hoidon, toisi varman ansion ja ilmaiset polttopuut tilattomille sekä lisäisi valtion tuloja. Sosialidemokraatit katsoivat, ettei valtion saama puolisko ollut pakkoluovutusta, koska edeltävinä vuosina metsien arvo oli kohonnut nopeasti. Eduskunnan porvarilliset ryhmät vastustivat metsäyhdyskuntia, joskin maalaisliitto ja vanhasuomalaiset myönsivät, että niistä voisi olla hyötyä. Lopuksi Gylling vetosi köyhälistöön, että nämä tukisivat sosialidemokraatteja tämän kysymyksen edistämiseksi. ${ }^{437}$

Eduskunnan porvarillinen enemmistö oli asiassa päinvastaista mieltä, joten talousvaliokunta esitti vuonna 1909, että valtion metsämaita luovutettaisiin yksityisille pikkutiloille. Gyllingin mielestä tämä on väärin, varsinkin kun metsää annettaisiin yli kotitarpeen, jotta se riittäisi tukemaan maanviljelijän taloutta. Näin tuettaisiin maanviljelystä toisen elinkeinon avulla. Gylling totesi, että maatalousvaliokunta vastusti edellisenä vuotena maanluovutusta, kuten myös porvarilliset asiantuntijat. Hän viittasi todennäköisesti ainakin Gebhardiin, joka vastusti myös talousvaliokunnan esitystä, koska ei uskonut pientilojen pystyvän harjoittamaan kestävää metsätaloutta. Eduskunta asettui kuitenkin kannattamaan metsien luovutusta. ${ }^{438}$

437 Gylling, Edvard, Köyhälistö metsäolojen uudistusta ajamaan. Työmies 13.5.1908 (A); vrt. Korpinen 1981, s.44.

4381908 II VP, ptk. s.285-287,433. 
Gylling totesi vuoden 1909 valtiopäivillä, että valtio on saanut metsistään varsin hyvin tuottoa. Samalla hän kuitenkin arvosteli metsähallituksen kantaa, jonka mukaan tavoitteena pitää olla entistä suuremmat voitot mahdollisimman pienillä menoilla. Gylling pelkäsi, että tämä saattaa johtaa metsän ryöstökäyttöön. Hänen mukaansa valtion pyrkimys voiton maksimointiin hakkaamalla liikaa metsää oli jo johtanut puun ylitarjontaan. Gylling korosti, että valtion metsänhoidossa pitäisi kiinnittää huomiota siihen epäkohtaan, että huonojen kulkuyhteyksien takia vain jotkut metsäyhtiöt pystyvät ostamaan puuta ja saavuttavat samalla lähes monopoliaseman. Hänen mielestään valtion pitäisi aktiivisemmin rakentaa metsänhoitoa hyödyttäviä uittoväyliä, uittolaitteita, teitä, rautateitä ja kuivattaa vesiperäisiä maita. Tämä olisi sekä valtion varojen hyödyllistä käyttöä että antaisi tilattomalle väestölle työtä. ${ }^{439}$

Porvarilliset edustajat kannattivat joitakin näistä ajatuksista, joskaan yksiselitteistä hyväksyntää ne eivät saaneet. Yleisesti ottaen voi sanoa, että metsänhoidon tehostamista kannatettiin, mutta valtion toimenpiteitä ei pidetty ryöstöviljelynä. Gylling korosti vastauspuheenvuorossaan, ettei valtio voi toimia metsätaloudessaan yhtä lyhytjännitteisesti kuin yksityinen liikemies, joka ei voinut sijoittaa pääomaa metsään tarpeeksi pitkäksi aikaa. Vanhasuomalainen A. O. Kairamo (1858-1938, vuoteen 1906 Kihlman) katsoi, ettei ylhäältä käsin voida kovin tarkasti säädellä hakkuiden määriä tai puun hintaa. Eduskunnan porvarillinen enemmistö hylkäsikin Gyllingin ajamat ponnet valtion rakentamisesta ja soiden kuivattamisesta. ${ }^{40}$

Sosialidemokraattien Gyllingin johdolla ajama valtiojohtoinen metsäpolitiikka ei eduskunnassa vakuuttanut porvarillisia edustajia, jotka luottivat enemmän yksityisten toimijoiden toteuttamaan metsänhoitoon ja puunhakkuuseen. Tässä kysymyksessä näkyi selvästi sosialistisen ja porvarillisen ideologian eroavaisuudet.

4391909 VP, ptk. s. 1158-1162.

4401909 VP, ptk., s.1162-1169. 


\section{Torpparit on itsenäistettävä!}

Maanvuokraajakysymyksen kuten muidenkin yhteiskunnallisten ongelmien ratkaisemista vaikeutti se, että Suomi oli autonomisesta asemastaan huolimatta osa Venäjän keisarikuntaa. Venäjän valtakunnanlainsäädännöllä tarkoitetaan lainsäädäntöä, joka ulotettiin koskemaan myös Suomen suuriruhtinaskuntaa. Valtakunnanlainsäädäntö pantiin alulle 1899 helmikuun manifestilla, jonka mukaan koko keisarikuntaa koskevien lakien säätäminen tuli tapahtua Venäjän lainsäädäntäjärjestystä noudattaen. Yleisvaltakunnallisiin lakeihin Suomen valtiopäivillä oli vain lausuntooikeus. Helmikuun manifestissa ei määritelty sitä, mitkä asiat olivat yleisvaltakunnallisia. Venäjän duuma sääti vuonna 1910 lain yleisvaltakunnallisesta lainsäädännöstä, jossa määriteltiin, mitkä asiat kuuluvat Suomen paikalliseen lainsäädäntöön ja mistä voidaan luokitella yleisvaltakunnallisen lainsäädännön kysymyksiksi. Tämä laki vähensi edelleen Suomen valtiopäivien mahdollisuutta ratkaista sisäpoliittisia ongelmia, mikä teki myös maatalouspolitiikasta entistä vaikeampaa. ${ }^{441}$

Vuonna 1909 säädetty uusi maanvuokralaki ja vuokrasuhteiden jäädyttäminen seitsemäksi vuodeksi tunnustettiin väliaikaiseksi ratkaisuksi. Siitä huolimatta maanvuokrajärjestelmän ongelmia voitiin nyt lähteä ratkaisemaan uudelta pohjalta, koska tilanne oli vakautettu ja järjestelmän epäkohdat olivat lainsäädäntötyön yhteydessä selkiytyneet. Kysymyksen tärkeyttä kuvastaa se, että maanvuokraajien asema oli jatkuvasti esillä yhteiskunnallisessa keskustelussa.

Uudistettuun maanvuokralainsäädäntöön esitettiin valtiopäivillä jatkuvasti muutoksia ja lisäyksiä, mutta ne kariutuivat sosialistien ja porvarillisen puolen jyrkkiin näkemyseroihin. Gylling oli kysymyksessä eräs aktiivisimmista kansanedustajista ja otti asiaan kantaa myös valtiopäivien ulkopuolella. Maanvuokrajärjestelmä oli kehittynyt eri puolilla maata erilaiseksi, eikä kaikkia sen puolia voitu yleistää koko maata kattavaksi. Keskeinen ristiriita oli joka

441 Tästä tarkemmin esim. Jussila 1979, s.246-248. 
tapauksessa maanomistajan ja maanvuokraajan välinen taloudellinen suhde. Ongelmakohtia olivat erityisesti vuokran oikeudenmukainen määrittely ja maanvuokraajan aseman epävarmuus. ${ }^{442}$

Peruskysymys oli se, kuinka paljon yhteiskunnan tulee puuttua yksityisten sopimuskumppanien välisiin suhteisiin. Koska tässä jouduttiin käsittelemään yksityisten kansalaisten taloudellisia ja oikeudellisia suhteita, asiasta tuli poliittinen kysymys. Ratkaisukeinojen perusteella voidaan erottaa kolme suuntausta. Oikeistolainen linja piti kiinni omistusoikeuden ehdottomasta koskemattomuudesta ja täydellisestä sopimusvapaudesta. Tätä linjaa ajoivat lähinnä RKP ja nuorsuomalaiset. Vasemmalla olevien sosialidemokraattien mielestä yhteiskunnan oli pakkolainsäädännöllä ratkaistava tilanne ja pitkällä aikavälillä otettava maa haltuunsa. Näiden kahden suuntauksen välissä oli keskustalainen sosiaalireformistinen linja, jota edustivat - tosin eri painotuksin - Maalaisliitto ja Suomalainen puolue. ${ }^{443}$

SDP:n vuoden 1909 Kotkan puoluekokouksessa Otto Ville Kuusinen katsoi, että puolueen ohjelma erityisesti maatalousohjelman osalta vaati korjaamista. Oskari Tokoi tuki häntä todeten, että maatalousohjelma oli monessa suhteessa pikkuporvarillinen. Puoluekokous asetti ohjelmakomitean, jonka jäseniksi tulivat Edvard Gylling, O. V. Kuusinen, Yrjö Sirola, Oskari Tokoi ja Sulo Wuolijoki sekä varajäseniksi Aatto Sirén (1873-1955), A. B. Mäkelä (1863-1932) ja Matti Paasivuori (1866-1937). Sen ensisijainen tehtävä oli maatalousohjelman uudistaminen. ${ }^{44}$

Kotkan puoluekokouksessa todettiin, että maanvuokraajien passiivinen vastarinta oli tuottanut tulosta, sillä vain pieni osa maanomistajista oli uskaltanut häätää vuokralaisiaan ennen uuden maanvuokralain voimaantuloa. Puolueen keskustoimikunta - mihin myös Gylling kuului - oli avustanut maanvuokraajia erilaisilla neuvoilla ja keräämällä tilastoa maanvuokraajaliikkeestä. ${ }^{445}$

442 Soininen 1999, s.44-45.

443 Vrt. Rasila 1970, s.46-47.

444 SDP:n VI PK, s.10-11,143, 204.

445 SDP:n VI PK, s.21-22. 
Vaikka puolueen maatalousohjelma sai Kotkassa osakseen arvostelua, se säilytettiin kuitenkin ennallaan. Toisaalta se kuitenkin tunnustettiin vanhentuneeksi, koska ohjelmakomitea asetettiin valmistelemaan uudistuksia.

Kolmas maanvuokraajien valtakunnallinen kokous järjestettiin Tampereella 18.-20.4. 1910. Kokouksessa oli 308 osanottajaa, jotka edustivat noin 30000 maanvuokraajaa. Tämän lisäksi 30 kansanedustajalle ja muulle "puoluetoverille" myönnettiin läsnäolo- ja puheoikeus. Tämä kokous vaati vielä viljelyspakkoa. Alun perin Gyllingin piti alustaa kysymyksestä "tilattoman väestön asuttaminen ja viljelyspakko", mutta hän oli estynyt, joten asiasta keskusteltiin ilman varsinaista alustusta. Ensimmäisen puheenvuoron pitänyt Tokoi puolusti viljelyspakkoa todeten, että se ei ollut ihanteellinen ratkaisu, mutta kuitenkin paras käytettävissä olevista keinoista. Kokous asettuikin viljelyspakon, kuten myös muiden sosialidemokraattien maanvuokraajien asemaa koskevien vaatimusten, taakse. ${ }^{446}$ Tampereen maanvuokraajakokouksen keskeisin kysymys oli maanvuokraajien järjestäytyminen. Keskustelun jälkeen päätettiin perustaa valtakunnallinen Maanvuokraajien Liitto, jonka toiminta jäi kuitenkin varsin vaatimattomaksi, sillä sen jäsenmäärä pysyi maanvuokraajien kokonaismäärään nähden perin pienenä. ${ }^{447}$

Maanvuokraajakokouksen jälkeen Gylling kirjoitti Työmiehessä, että maanvuokraajat ja tilaton väestö tukevat edelleen vahvasti sosialidemokraatteja. Hänen mukaansa SDP olikin ainoa puolue, joka kykeni uudistamaan "köyhälistön etujen mukaisesti vanhentunutta feodaalisperäistä agraarijärjestelmäämme", koska se ei ollut sidoksissa maanomistajien "kehityksenvastaisiin pyyteisiin ja vanhenneisiin etuoikeuksiin". Marxilaisen teorian mukaisesti Gylling katsoi kuitenkin, ettei maanvuokraajaluokka voi pitkällä tähtäimellä kannattaa sosialidemokraatteja, koska se ei ole kapitalistisen kehityksen synnyttämä. Kannatusta toivat vanhentuneet

446 Maanvuokraajien kolmannen yleisen edustajakokouksen ptk., Helsinki 1910, s.23-39.

447 Maanvuokraajien kolmannen yleisen edustajakokouksen ptk., Helsinki 1910, s.20-22, esitysvihko, s.5-9; Rasila 1961, s.86-87. 
agraariolot ja porvarien lyhytnäköinen politiikka. Gylling huomautti, että agraariolojen uudistuttua SDP saattaisi menettää näiden ryhmien kannatuksen. Sen sijaan kaupunkien lisääntyvässä teollisuusköyhälistössä oli sosialidemokraateille kasvava voimavara. $^{448}$

Eräät porvarilliset edustajat jättivät vuoden 1911 valtiopäiville pientilojen muodostamiseen tähtäävän esityksen, joka noudatti aikaisempien aloitteiden linjaa. Sosialidemokraattiset edustajat kannattivat edelleen viljelyspakkoa ja vastustivat porvarien esitystä, koska siinä tarkoitus oli itsenäistää vain osa maanvuokraajista ja hyöty tulisi ensisijaisesti maanomistajille. Kannanotto ajoittuu kevääseen 1911, juuri ennen SDP:n uuden maatalousohjelman julkaisemista. ${ }^{449}$

Gylling otti toukokuussa 1911 eduskunnan yleiskeskustelussa kantaa pienviljelykseen. Hän korosti tieteellisen tutkimuksen merkitystä yhteiskunnallisten uudistusten pohjana ja totesi, ettei tutkimus ollut vielä pitävästi osoittanut, minkälainen maanviljelys oli tehokkainta. Kysymys pitäisi tutkia perin pohjin ennen mitään toimenpiteitä. Gylling itse arveli seuraavaa. Jos maanviljelijäväestö muodostaa lähes koko väestön, pienviljelys on suurviljelystä tehokkaampaa, koska se antaa suurimman bruttotuloksen hehtaaria kohti. Maanviljelijöiden osuuden supistuessa suurviljelyksestä tulee yhä tehokkaampi viljelymuoto, koska se antaa suurimman tuloksen ihmistyötä kohti. Kun Suomessakin maanviljelyksen merkitys väheni, suurviljelys osoittautuisi todennäköisesti järkevämmäksi ratkaisuksi. Gylling korosti sitä, että porvarillisten puolueiden tarkoitus oli ennen kaikkea poliittisista syistä kasvattaa pienviljelijöiden lukumäärää. ${ }^{450}$

Syntyneessä keskustelussa sosialidemokraatit Kuusisen ja Tokoin johdolla tukivat Gyllingiä mutta porvarilliset edustajat katsoivat, että myös viljelyspakkovaatimus perustui lähinnä poliittisiin pyrkimyksiin. Heidän mielestään myöskään viljelyspakon

448 Gylling, Edvard, Vielä eräitä vaalitilaston opetuksia. Työmies 1.7.1910 (F).

449 Rasila 1970, s.112-113.

4501911 VP, ptk., s.595-599. 
vaikutuksia ei ollut tyydyttävästi selvitetty. Maalaisliiton edustaja Filip Saalasti (1866-1918) korosti sitä, että maanviljelys oli edelleen Suomen ehdoton pääelinkeino, joten sen pitäisi olla ajattelun lähtökohta. ${ }^{451}$

Vuoden 1911 valtiopäivien pientila-asutusehdotuksen ja viljelyspakkoaloitteen yhteisessä kolmannessa käsittelyssä vilkas ja värikäs keskustelu aiheesta jatkui. Torpparinpoika Evert Eloranta (1879-1936) esitti ensimmäisenä johtavana sosialidemokraattina lunastukseen perustuvan torpparivapautuksen. Hän esitti tämän ajatuksen 15.5.1911, jolloin sosialidemokraattisen puolueen ohjelmakomitea oli saanut ohjelmamietintönsä valmiiksi, vaikkei sitä ollutkaan vielä annettu julkisuuteen eikä puoluekokous ollut vielä hyväksynyt sitä. ${ }^{452}$

Nuorsuomalaisten edustaja Jonas Castrén (1850-1922) otti päämaalikseen sosialidemokraattien, erityisesti Gyllingin ja Kuusisen, käsitykset maatalouden kehityksestä. Hän siteerasi laajasti tutkijoita, joiden mukaan pienviljelys on suurviljelystä tehokkaampaa ja sen merkitys on lisääntymässä. Castrén nosti esille myös sosialidemokraattisten revisionistien Eduard Bernsteinin ja Edward Davidin näkemyksiä ja katsoi myös, että Karl Kautsky on lieventänyt kantaansa pienviljelyksen heikkoudesta. Tämän jälkeen hän kehotti "herroja Gylling ja Kuusinen" tutustumaan näihin tutkimuksiin, kuten myös Britannian ja Saksan politiikkaan asian suhteen. Castrén tiivisti näkemyksensä siihen, että vaikka viljelyspakko on mahdotonta toteuttaa, niin sosialidemokraatit "virittävät virvatulia tilattomalle maalaisväestölle ja yrittävät sitä sillä eksyttää" ${ }^{453}$

Gylling totesi omassa puheenvuorossaan, ettei edustaja Castrénin "loruilu ansaitse mitään vastausta". Hänen mukaansa porvarit olivat taantuneet torpparipolitiikassaan viime vuosina, kun olivat siirtyneet ajamaan torpparivapautusta ostopolitiikalla pakkolainsäädännön sijasta. Gylling hyväksyi maanvuokraajien tekemi-

4511911 VP, ptk., s.599-623.

4521911 VP, ptk., s.681-682; Rasila 1970, s.120.

4531911 VP, pkt., s.793-804. 
sen maanomistajiksi, kunhan ei hyväksytty maan hankkimista maanomistajan ja vuokraviljelijän vapaalla sopimuksella. Tämä olisi merkinnyt yksiselitteisesti vahvemman eli maanomistajan oikeutta. Lisäksi uudistus koskisi vain osaa maanvuokraajista. Gyllingin mukaan maanvuokraajien vapautus voitiin toteuttaa vain pakkolainsäädännöllä. Ainoastaan näin he eivät menettäneet omistusoikeutta, joka heillä tosiasiallisesti oli tiloihinsa. ${ }^{454}$

Gylling sai tukea usealta sosialidemokraattiselta kansanedustajalta. Kuusinen kutsui Castrénin puhetta "lystikkääksi loruiluksi" ja tuki voimakkaasti Gyllingiä. Muut sosialidemokraattiset puhujat olivat samalla kannalla, mutta varovaisin sanakääntein, minkä taustalla voi nähdä puolueen maatalousohjelman muutostilasta. Porvarilliset edustajat arvostelivat Gyllingin esitystä voimakkaasti ja Paasikivi uudisti kysymyksen kansainvälisen sosialidemokratian kannasta asiaan. Porvarilliset edustajat yrittivät taitavasti hyödyntää sosialidemokraattien epävarmaa kantaa maatalouden kehityksen suhteen. Porvarillisten puolueiden asetusehdotukset pientiloista ja Suomen maalaisväestön asutusrahastosta voitiin siirtää yli vaalien 1/3 eli 67 edustajan voimin. SDP:n edustajat äänestivät ehdotukset seuraaville valtiopäiville. Useat porvarilliset edustajat jättivät päätökseen vastalauseensa. ${ }^{455}$

Sosialidemokraattiset kansanedustajat siis tukivat toukokuussa 1911 maanvuokraajien tekemistä maanomistajiksi, kunhan muutoksen muodot määrättiin lailla. Tämä uusi kanta perustui puolueen ohjelmakomitean - jossa Gyllingin osuus oli keskeinen - linjauksiin. Gylling vetosi myös maanvuokraajien "tosiasialliseen omistusoikeuteen" tiloihinsa, mikä tarkoittanee samaa kuin ohjelmakomitean mietinnössä esitetty "varsinainen asumisoikeus". Komitea katsoi, ettei torppareilla ja mäkitupalaisilla ollut tilaansa ainoastaan vuokraoikeutta, vaan usein paljon täydellisempi "varsinainen asumisoikeus", jonka turvaaminen oli tärkein tehtävä. Komitea ei määritellyt, mitä se tarkoitti varsinaisella asumisoikeudella, eikä tuollaista määrittelyä tehty myöhemminkään. Mie-

4541911 VP, ptk., s.814-817.

4551911 VP, ptk., s.820-830. 
tinnössä tosin viitattiin siihen, että vuokramiehet usein viljelivät samaa tilaa, johon he alun perin olivat saaneet "suoranaisen oikeuden" perinnön tai ostamisen kautta. Varsinaisella asumisoikeudella tarkoitettiin ilmeisesti lähinnä raivaajan oikeutta raivaamaansa alueeseen silloin, kun hän ei ollut tehnyt sitä toisen palkkaamana eli ensisijaisesti työn tulosten omistusoikeutta. Siihen sisältyi myös suoranainen oikeus, mikä perustui esimerkiksi perintöön tai ostoon. Laki ei tuntenut tämänlaista varsinaista asumisoikeutta, vaan sen kannalta kysymys oli joka tapauksessa tavallisesta maan käyttöoikeudesta, mikä päättyi vuokrasopimuksen loppuessa. ${ }^{456}$

Sosialidemokraattinen eduskuntaryhmä oli siis irtautunut viljelyspakkovaatimuksesta ja asettunut kannattamaan maanvuokraajien itsenäistämistä ennen kuin puoluekokous oli hyväksynyt tämän uuden linjauksen. SDP oli vaatinut viljelyspakon toteuttamista vuodesta 1906 lähtien. Vuoden 1911 aikana tämä peruslinjaus muuttui, kun pienviljelyksen haitallisuutta alettiin korostaa entistä voimakkaammin. Viljelyspakon toteuttaminen olisi käytännössä tukenut pienviljelystä, minkä takia sosialismin voitto olisi saattanut viivästyä. Lisäksi viljelyspakon ajaminen oli käytännössäkin osoittautunut erittäin vaikeaksi, koska eduskunnassa kaikki porvarilliset puolueet tuomitsivat sen jyrkästi.

Oskari Tokoin huhtikuussa 1911 kirjoittama artikkelisarja Maatalouskysymyksemme pohjusti taitavasti viljelyspakosta luopumista. Tokoi totesi, ettei omistusoikeus sinänsä ole niin merkittävä asia toiminnan kannalta kuin usein väitetään, vaan taloudelliset edut ovat tärkeämpiä. Hän korosti samalla sitä, että maanomistajan intressit ovat maan omistajana toiset kuin maan viljelijänä. Tokoin mukaan omistusoikeutta ei siis voi pitää ihannepäämääränä, eikä vuokraviljelmän lunastamista itsenäiseksi voidakaan puolustaa itsenäisyyden vaan taloudellisten etujen takia. Tokoi asettui viljelyspakon kannalle, mutta totesi, ettei se käytännössä ole toteutettavissa kuin sosialistisessa yhteiskunnassa, jossa olisi jo muitakin keinoja asioiden parantamiseksi. Näin ollen hän ei käytännössä pitänyt viljelyspakkovaatimuksesta kiinni. Samalla hän

456 SDP:n VII PK, ohjelmakomitean mietintö, s.73-84; Rasila 1970, s.99-101. 
totesi pientilojen ja suurtilojen välisen kannattavuuskysymyksen olevan edelleen ratkaisematta. ${ }^{457}$

SDP:n puoluekokous pidettiin syyskuussa 1911 Helsingissä. Kotkan puoluekokouksessa asetettu ohjelmakomitea antoi Helsingin kokoukselle mietintönsä. Tarkoituksena oli ollut koko puolueohjelman tarkastelu, mutta ajanpuutteen vuoksi mietinnössä rajoituttiin lähinnä maatalousohjelmaan, joka olikin ollut komitean ensisijaisena kohteena. Komitean työn tuloksena syntyi laaja ja perusteellinen selvitys maatalousväestön asiasta. Mietintö oli ennen kaikkea Gyllingin, mutta osin myös Kuusisen käsialaa. ${ }^{458}$

Ohjelmakomitean maatalousohjelma alkoi historiallisella katsauksella maalaisväestön asemaan, missä Gyllingin kädenjälki näkyy selvästi. Katsauksen mukaan 1800-luvun loppupuolella kapitalismi alkoi kehittyä nopeasti maaseudulla. Taustalla oli metsän arvon nousu, minkä takia talolliset estivät uusien torppien perustamisen sekä supistivat maanvuokraajien ja tilattomien metsänkäyttöoikeuksia. Kaiken kaikkiaan maanvuokraajien asema huononi ja tilattomien määrä lisääntyi. Ohjelmakomitea päätteli, että kapitalismi oli aiheuttanut luokkaristiriitojen kärjistymisen maaseudulla. ${ }^{459}$

Gylling painotti usein 1800-luvun loppupuolella Suomen maaseudulla tapahtunutta voimakasta kapitalistista kehitystä ja siitä aiheutunutta luokkaerojen lisääntymistä. Suomalaisista tutkijoista Jaakko Forsman (1867-1946) jakoi tämän ilmeisen perustellun käsityksen, joskaan hän ei Gyllingin tapaan tulkinnut kehitystä tiukan marxilaisesti. ${ }^{460}$

Ohjelmakomitean mukaan Suomen kapitalistinen kehitysaste oli 1900-luvun alussa sama kuin kehittyneimmissä maissa kapitalismin syntyaikoina. Komitea katsoi, että ohjelmassa oli olennaista kaksi näkökulmaa: 1. työväen etu ja 2. yhteiskunnallinen ja taloudellisen edistys. Mietinnön mukaan "köyhälistö ei porvarillises-

457 Rasila 1970, s.93-94.

458 SDP:n VII PK, ohjelmakomitean mietintö, s.26; Soikkanen 1975, s.160.

459 SDP:n VII PK, ohjelmakomitean mietintö, s.26-35.

460 Forsman, Jaakko, Mistä syystä sosialismi levisi Suomen maalaisväestön keskuuteen? Mietteitä. Helsinki 1912, s.20-28,33,36-37. 
sa yhteiskunnassa voi päästä vapaaksi”, mutta yhteiskunnallinen ja taloudellinen edistys voi parantaa jonkin verran sen asemaa. Tätä pitäisi tukea laatimalla uusia lakeja maatyöväen työehdoista ja asunto-oloista. Näin olisi mahdollista päästä irti "feodalisesta orjuuttavasta riippuvuudesta". ${ }^{461}$ Komitean kannassa näkyi pyrkimys yhdistää uudistuspolitiikka ja vallankumouksellisen tilanteen odotus, joskin painopiste oli yhteiskunnallisissa reformeissa.

Komitean esittämistä näkemyksistä tärkein oli Forssan ja Oulun puoluekokouksissa hyväksytyn pienviljelystä suosivan linjan kyseenalaistaminen. Mietinnön mukaan viljelyspakolla saataisiin tilattomille riittävästi maata ja estettäisiin mahdollisuus heidän viljelystensä anastamiseen, mutta olennaista oli kuitenkin pienviljelyksen kannattavuus. Jos se oli niin huono, ettei viljelijä menesty, niin pienviljelystä oli turha tukea. Viljelyspakosta luopumista ehdotettiin, koska missään ei ollut osoitettu, että pienviljelys olisi tehokkaampaa kuin suurviljelys. Pidettiin myös epäselvänä, olisiko pienviljelijöiksi muuttuminen maalaisköyhälistölle hyväksi. Koska kysymyksestä oli saatu ristiriitaisia tutkimustuloksia, haluttiin tehdä lisätutkimuksia ja asettua toistaiseksi odottavalle kannalle. Komitea ehdotti, ettei puolue toistaiseksi ajaisi pienviljelyksen lisääntymistä tukevia uudistuksia. Viljelyspakon vaatimisesta pitäisi toistaiseksi luopua, koska siitä aiheutuvaa pientilojen lukumäärän nousua ei välttämättä pidetty hyvänä asiana. Jos se kohottaisi tuotantoa, komitean mukaan hyöty menisi kapitalismissa lähinnä suurviljelijöille. ${ }^{462}$

Komitea tarkasteli "torpparien ja mäkitupalaisten asemaa" ja totesi, että maanvuokrajärjestelmä soveltui luontaistalouteen, mutta rahataloudessa vuokramiehen asema on usein heikompi kuin palkkatyöläisen. Maanvuokraajan siirtyminen teollisuusväestön osaksi merkitsee usein olojen parantumista mutta teollisuuden kehittymättömyyden takia se on Suomessa vaikeampaa kuin Ruotsissa. Vuoden 1909 asetus ei parantanut vuokramiehen asemaa paljoakaan, koska vero jäi määriteltäväksi päivätöiden ny-

461 SDP:n VII PK, ohjelmakomitean mietintö, s.36-44.

462 SDP:n VII PK, ohjelmakomitean mietintö, s.45-73. 
kyarvon mukaan. Komitea korosti, että vuoteen 1916 päättyvän välikauden loppuun mennessä tähän pitäisi löytää ratkaisu, joka turvaisi maanvuokraajien oikeudet. Ohjelmakomitea kannatti erityisen komitean asettamista valmistelemaan valtiopäiväaloitetta maanvuokraajien vapauttamiseksi ja maatyöväen suojelemiseksi. $^{463}$

Vuokramiehen oikeuksia käsitellessään ohjelmakomitea toi siis esille käsitteen "varsinainen asumisoikeus", johon sosialidemokraatit usein vetosivat seuraavien vuosien aikana. Laki ei tuntenut tätä tarkasti määrittelemättä jäämättä käsitettä, vaan sen kannalta kysymys oli joka tapauksessa tavallisesta maan käyttöoikeudesta, mikä päättyi vuokrasopimuksen loppuessa. Varsinaisella asumisoikeudella tarkoitettiin ilmeisesti lähinnä raivaajan oikeutta raivaamaansa alueeseen silloin, kun hän ei ollut tehnyt sitä toisen palkkaamana eli ensisijaisesti työn tulosten omistusoikeutta. Laki ei tuntenut tämänlaista varsinaista asumisoikeutta, vaan sen kannalta kysymys oli joka tapauksessa tavallisesta maan käyttöoikeudesta, mikä päättyi vuokrasopimuksen loppuessa. Ohjelmakomitea kuitenkin katsoi, että tämän varsinaisen asumisoikeuden perusteella kaikki häädöt oli kiellettävä ja maanvuokraajat saatava tilojensa laillisiksikin omistajiksi. Tämä taas vaati takautuvaa lainsäädäntöä. Lunastus ei saisi tapahtua vapaaehtoista tietä, vaan laissa oli tarkoin määriteltävä lunastussumman laskentatapa- ja perusteet. Tällöin oli vuokratilan arvosta vähennettävä kaikki ne oikeudet, joita vuokramiehelle tilaansa oli. Jos torppa oli saatu perintöosuutena, ei siitä saanut määrätä mitään lunastusta. Itse lunastuksen komitea ehdotti tapahtuvan siten, että valtio suorittaisi lunastushinnan maanomistajalle obligaatioilla ja itsenäistynyt vuokramies puolestaan valtiolle pitkäaikaisina maksuina. ${ }^{464}$

Kaiken kaikkiaan ohjelmakomitea ehdotti selvästi luopumista viljelyspakkovaatimuksesta, mutta kannatti samalla sitä, että puo-

463 SDP:n VII PK, ohjelmakomitean mietintö, s.73-84; Ruotsin elinkeinoelämän ja maatalouden kehitys oli tosiaan selvästi Suomea edellä. Siellä maaseudun väestö alkoi laskea nopeasti 1890-luvulta lähtien, ja maanvuokraajien osuus oli myös selvästi pienempi kuin Suomessa. Morell 2001, s.76-77.

464 SDP:n VII PK, ohjelmakomitean mietintö, s.73-84; Rasila 1970, s.99-101. 
lue jättäytyisi vaille sitovaa maatalousohjelmaa siksi aikaa, kunnes tarkempien tutkimusten perusteella voitaisiin tehdä uusi ja kehitystä paremmin vastaava ohjelma. Komitean ehdotuksen mukaan ainoaksi selväksi ohjelmaksi tässä asiassa jäisi se, että puolue ajaa kaikin voimin maatyöväen suojelemista, torpparien vapauttamista ja kansanvaltaisia uudistuksia. Sosialidemokraattien pyrkimys torpparien itsenäistämiseen merkitsi kuitenkin selkeästi uutta linjausta. ${ }^{465}$

Viljelyspakkoajatuksen hylkääminen ei ollut helppoa, sillä vuoden 1906 maanvuokraajien kokouksessa se oli ollut lupaus, jolla oli torjuttu oman maan vaatiminen. Lisäksi SDP:n eduskuntaryhmä oli tehnyt eduskunta-aloitteita viljelyspakosta ja se oli ollut tärkeä lupaus vaalitaistelussa. Vielä 1910 maanvuokraajien edustajakokous oli asettunut viljelyspakon kannalle ja useimmissa lehtikirjoituksessa oli pyritty ainakin ymmärtämään pienviljelystä. ${ }^{466}$ Komitean ehdotus saikin osakseen myös arvostelua. Osa Helsingin puoluekokouksen edustajista uskoi pienviljelyn kannattavuuteen ja puolusti viljelyspakkoa, koska sen avulla pakotettaisiin maanomistajat viljelemään maataan. Samoin arvosteltiin sitä, että tärkeässä maatalouskysymyksessä jäätäisiin ohjelmattomaan tilaan. ${ }^{467}$

Gylling piti kaksi puheenvuoroa, joissa hän puolusti taitavasti komitean linjauksia, kuten maalaisköyhälistön työehtojen ja asunto-olojen parantamista sekä erityisesti maanvuokraajien vapauttamista. Pienviljelystä oli hänen mukaansa turha puolustaa, koska pitkällä tähtäimellä siitä saattoi olla maalaisköyhälistölle haittaa. Maanvuokraajien aseman parantaminen lainsäädännöllä oli tärkeintä, koska myös tilattomien asema parantuisi sitä kautta. Viljelyspakko kannatti poistaa ohjelmasta senkin takia, ettei sillä ollut eduskunnassa mahdollisuutta läpimenoon. Gylling kehotti

465 Rasila 1970, s.98-99.

466 Soikkanen 1975, s.160.

467 SDP:n VII PK, s.108-111,159. 
hyväksymään valiokunnan ponnet ja korosti, etteivät porvarillisten puolueiden ohjelmat olleet lähellekään yhtä radikaaleja. ${ }^{468}$

Helsingin puoluekokouksessa äänestettiin ohjelmakomitean mietinnön pohjalta uudesta maatalousohjelmasta. Pyrkimys maanvuokraajien vapauttamiseen sekä maalaistyöväen työ- ja elinolosuhteiden parantamiseen hyväksyttiin yksimielisesti. Komitean esitykseen lisättiin, että puolue pyrki edistämään maatyöläisten ammatillista järjestäytymistä. Viljelyspakkovaatimuksesta irtauduttiin äänin 57-36. ${ }^{469}$ Puolueen maatalousohjelmaa ei muutettu vuoden 1913 puoluekokouksessa.

Puoluekokouksen päätökset merkitsivät, että SDP siirtyi ajamaan varsinaisen tilattoman väestön kysymyksestä irrotettua maanvuokraajakysymystä. Viljelyspakkovaatimuksessa jo olemassa olevia maanvuokraajia ei mitenkään erotettu varsinaisista tilattomista, joille olisi pitänyt hankkia maata viljeltäväksi. Koska vuokra olisi edelleen maksettu yksityisille viljelijöille, viljelyspakko ei olisi tuonut entisille maanvuokraajille muuta muutosta kuin että SDP:n ajaman vuokralain mukaan vuokraoikeus olisi muuttunut pysyväksi ja vuokran määrä puolueettomien lautakuntien määräämäksi. ${ }^{40}$

Kuten Viljo Rasila toteaa, uusi maanvuokraajien itsenäistymiseen pyrkivä linjaus perustui yksityisen omistusoikeuden tunnustamiseen ja suosimiseenkin, eikä siis ollut sosialistinen. Se tunnusti myös maanomistajan omistusoikeuden esittäessään myös, että joissakin poikkeustapauksissa maanomistajalla oli oikeus pitää vuokratila omistuksessaan. ${ }^{471}$ Hannu Soikkanen on toisaalta huomannut hyvin sen, että ohjelmakomitea pyrki pois pienviljelyksen tukemisesta, koska se saattaisi hidastaa sosialistisen yhteiskunnan voittoa kapitalismista ${ }^{472}$.

468 SDP:n VII PK, s.159-164.

469 SDP:n VII PK, s.164-165.

470 Rasila 1970, s.99.

471 Rasila 1970, s.101.

472 Soikkanen 1975, s.161. 
Tampereella pidettiin 30.10.-1.1.1911 jälleen maanvuokraajien edustajakokous. Tässä kokouksessa pyrittiin saamaan maanvuokraajat viljelyspakon hylkäämisen kannalle, kuten puoluekokouksessa oli päätetty. Maatalouskysymyksen käytännöllisen puolen alusti kokouksen puheenjohtajana toiminut Tokoi ja periaatteellisen osan Gylling. ${ }^{473}$

Tapansa mukaan Gylling aloitti käsittelynsä maatalouskysymyksen historiallisesta taustasta. Kapitalistisen kehityksen alkaessa Suomessa 1800-luvun toisella puoliskolla tilattoman väestön määrä kasvoi nopeasti. Se oli alustajan mukaan kapitalismille välttämätöntä, koska teollisuus tarvitsi lisätyövoimaa. Vaikka tilaton väestö oli siis ainoastaan hetkellinen ilmiö, sen asema oli kuitenkin sillä hetkellä polttava ongelma. Gylling katsoi, että tilattomien siirtyminen kaupunkeihin ja teollisuuteen oli oikea kehityssuunta. Porvarit pyrkivät kuitenkin tekemään heistä pienviljelijöitä, koska maan kysyntä kasvatti sen hintaa ja tilattomat olivat yhteiskunnallisesti radikaaleja. Gyllingin mukaan porvareille oma hyöty oli tilattomien etua tärkeämpää. Sosialidemokraatit pyrkivät tilattoman aseman parantamiseen siten, ettei työväen luokka-asema heikenny. ${ }^{474}$

Gylling puolusti odottavaa kantaa viljelyspakon suhteen, koska pienviljelijän asema ei välttämättä ole parempi kuin palkkatyöläisen ja näiden kahden ryhmän edut ovat usein ristiriidassa. Kaiken lisäksi viljelyspakon läpimeno olisi mahdollista ehkä vain uuden suurlakon kaltaisen mullistuksen aikana. Sekä maanvuokraajien että tilattomien kannalta oli käytännöllisempää ajaa maanvuokraajien vapautusta, työväensuojelun ulottamista maatyöväkeen, maatyöväen järjestäytymistä, asunto-olojen parantamista sekä yleistä ja yhtäläistä kunnallista äänioikeutta. ${ }^{475}$

473 Maanvuokraajien neljännen yleisen edustajakokouksen ptk. Tampere 1911, s.38, 44 .

474 Maanvuokraajien neljännen yleisen edustajakokouksen ptk. Tampere 1911, s.44-48.

475 Maanvuokraajien neljännen yleisen edustajakokouksen ptk. Tampere 1911, s.48-54. 
Myös kokouksen puheenjohtaja Oskari Tokoi asettui tukemaan viljelyspakon hylkäämistä, koska se voisi heikentää pitkällä aikavälillä työväenluokan asemaa. ${ }^{476}$ Monet kokousedustajat puolustivat viljelyspakkoa perusteluinaan muun muassa, että teollisuutta oli riittämättömästi työllistämään koko tilaton väestö. Gyllingin mukaan alustuksessa esitetty ohjelma toisi viljelyspakkoa enemmän etua maanvuokraajille, koska porvarit oli mahdollista saada sen taakse. Hän kehotti maanvuokraajia vaatimaan tilojensa lunastamista. Kokous päätti pitää edelleen viljelyspakosta periaatteessa kiinni mutta uudistaa vaatimuksensa vasta, kun sillä on mahdollisuus toteutua. ${ }^{477}$

Keskustelussa näkyi teoreettisemmin orientoituneen puoluejohdon ja välittömiä etujaan ajaneiden maanvuokraajien välinen ristiriita. Ohjelmakomitea ei ollut ottanut kantaa kansainvälisen sosialidemokratian kiistaan siitä, oliko pienviljelys tehokkaampaa kuin suurviljelys. Kuitenkin marxilaisen yhteiskunnallisen peruskäsityksen mukaisesti se selvästi piti pienviljelyksen tukemista ongelmallisena. Teoreettisen ajattelun lisäksi taustalla vaikutti myös se, että Gylling, Tokoi ja muu puoluejohto ymmärsivät kokouksen riviedustajia paremmin poliittisen tilanteen asettamat rajoitukset.

Sosialidemokraatit asettuivat siis vuonna 1911 kannattamaan torpparien itsenäistämistä. Puolueen uusikaan kanta ei ollut sosialistinen, koska se suosi yksityistä omistusoikeutta ja ainakin väliaikaisesti tuki kapitalistista talousjärjestelmää. Taustalla oli todennäköisesti myös pyrkimys lisätä sosialidemokraattien kannatusta ja joukkovoimaa, jota itsenäistämisvaatimuksen ajateltiin tukevan. Gyllingin johdolla Suomen sosialidemokraatit olivat siis tässä kysymyksessä valmiita tinkimään marxilaiselta linjalta

476 Oskari Tokoi oli SDP:n johtajista vastahakoisimpia siirtymään viljelyspakon vastustajaksi. Hän oli vielä keväällä 1911 kannattanut viljelyspakkoa, vaikka arvioikin, että se olisi toteutettavissa vasta sosialistisessa yhteiskunnassa. Rasila 1970, s.93-94.

477 Maanvuokraajien neljännen yleisen edustajakokouksen ptk. Tampere 1911, s.55-63; Rasila 1970, s.104. 
hieman revisionistisimmille linjoille ja tekemään käytännöllisen reformin. ${ }^{478}$

Porvarillinen lehdistö otti sosialidemokraattien linjaukset kriittisesti vastaan, mutta siitä huolimatta sosialidemokraattien kannatus jatkoi kasvuaan. Viljo Rasilan mukaan tähän oli kolme syytä: 1. maanvuokraajaväestöä uusi itsenäistämisohjelma tyydytti varmasti paremmin kuin viljelyspakkovaatimus, 2 . mietintö oli niin hyvin laadittu ja laajasti perusteltu, että viljelyspakon kannattajienkin oli taivuttava ja 3. maaseudun tilaton väestö ei ehkä halunnut maanviljelijäksi niin suuressa määrin kuin oli ajateltu. $\mathrm{Ku}-$ ten Rasila toteaa, ettei jättäytyminen ilman maatalousohjelmaa ei merkinnyt pitkän aikavälin tavoitteiden puuttumista. Päinvastoin mietinnössä erityisesti korostettiinkin lopullisten sosialististen tavoitteiden ensisijaisuutta hetkellisten parannusten rinnalla. ${ }^{479}$

\section{Maatalouskysymysten ratkaisuyrityksiä valtiopäivillä}

Vuoden 1912 valtiopäiville tultaessa sekä sosialidemokraatit että porvarilliset puolueet olivat valmiita itsenäistämään maanvuokraajat. Keinoista vallitsi kuitenkin jyrkkä erimielisyys. Sosialidemokraatit tekivät laajan anomusehdotuksen vuokramiehille myönnettävistä oikeuksista ja vuokraolojen järjestämisestä. Gylling oli ehdotuksen ensimmäinen allekirjoittaja ja puolueen maatalousasiantuntijana todennäköisesti myös tekstin kirjoittaja. Hänen korostamansa asiat olivat vahvasti esillä anomusehdotuksessa, missä painotettiin maanvuokraajien olojen tieteellistä selvittämistä ja historiallista taustaa. Ehdotuksessa todettiin, että vuoden 1909 maanvuokralaki paransi vuokramiehen asemaa riittämättömästi mutta se kuitenkin suojasi jonkin verran maanomistajan mielivallalta. Ongelmana pidettiin sitä, että maanvuokraaja yleensä pääsi lain piiriin vasta uutta sopimusta tehtäessä tai vanhaa uudistettaessa. Lukuun ottamatta joitakin taannehtivia

478 vrt. Rasila 1970, s.224-226. SDP:n sisällä oli vielä vuoteen 1915 tätä päätöstä vastustavia henkilöitä, mutta heidän kannatuksensa oli vähäistä.

479 Rasila 1970, s.109. 
säädöksiä uuden vuokralainsäädännön arvioitiin jäävän tehottomaksi. Tärkeimmät taannehtivista säädöksistä olivat määräys lain voimaantulon jälkeen loppuvien vuokrasopimusten pidentämisestä korkeintaan seitsemällä vuodella ja säädös, missä rajoitettiin maanomistajan oikeutta irtisanoa vuokralaisensa. Ne estivät vuokramiesten mielivaltaiset häädöt vuoteen 1916 saakka, mutta tämän jälkeen rauhoitusaika päättyi asteittain. ${ }^{480}$

Ehdotuksessa arvosteltiin hallitusta siitä, ettei se ollut koonnut tarkkoja tietoja vuoden 1916 jälkeen turvattomaan asemaan joutuvien maanvuokraajien lukumääristä. SDP:n mielestä tämä osoitti hallituksen täydellistä välinpitämättömyyttä laajojen väestönkerrosten elinoloista. Hallitus ei ollut myöskään tehnyt selvitystä vuokramiesten vuokramaksuista tai veroista. ${ }^{481}$ Tässä kuuluu selvästi Gyllingin ääni. Hän oli vaatinut jo vuoden 1910 alussa, että lain vaikutuksesta pitäisi laatia tilastoja, joiden pohjalta voitaisiin suunnitella lisäuudistuksia. ${ }^{482}$

Anomusehdotukseen sisältyi historiallinen katsaus maanvuokrausjärjestelmän kehityksestä Suomessa. Sen mukaan suurviljelys syntyi 1600-luvulla, jolloin syntyivät feodalismille ominaiset alustalaissuhteet. Siitä lähtien maanomistajien ja maanvuokraajien väliset olosuhteet olivat säilyneet pääpiirteittäin ennallaan. Ehdotuksessa todettiin 1700-luvun lopulta alkaneen kapitalistisen kehityksen moninkertaistaneen maanvuokraajien lukumäärän. Kuitenkin sen mukaan 1800-luvun jälkipuoliskolla maanvuokraajien tosiasiallinen asumisoikeus vuokratiloihinsa alkoi horjua, jolloin maanvuokraajien oikeudet supistuivat ja lukumäärän kasvu pysähtyi. Tämän kehityksen taustalla olivat taloudellisen muutokset, kuten metsätuotteiden nopea arvonnousu ja karjanhoidon lisääntymisestä johtunut päivätyön merkityksen lasku. Lisäksi myös lainsäädännöllä vähennettiin maanvuokraajien oikeuksia. Viimeaikainen kehitys oli huonontanut vuokramiesten taloudellista asemaa ja jätti heidät avuttomina isäntänsä armoil-

4801912 VP, anomusehdotus n:o 60, liitteet VIII, s.74-78.

4811912 VP, anomusehdotus n:o 60, liitteet VIII, s.79-82.

482 Gylling, Edvard, Mitä uusi torpparilaki vaikuttaa ja miten sitä noudatetaan? Työmies 25.2.1910(E). 
le. ${ }^{483}$ Anomusehdotuksessa esiintyi jälleen käsite "tosiasiallinen asumisoikeus", minkä siinä katsottiin syntyneen sukupolvia kestäneen raivaus- ja viljelystyön kuluessa, kunnes se alkoi horjua 1800-luvun loppupuolella.

Sosialidemokraattien eduskuntaryhmän mukaan maanvuokraajien pitäisi saada tilaansa joko täysi omistusoikeus tai vakaa ja jatkuva hallintaoikeus. Heille olisi myönnettävä täydellinen vapaus viljellä ja käyttää tilaansa, mukaan luettuna oikeus siirtää se toiselle. Vallitseva raskas päivätyövelvollisuus olisi muutettava kohtuulliseksi rahasuoritukseksi. Tässä pitäisi huomioida se, ettei vuokramies joutuisi maksamaan veroa siitä, minkä on itse raivannut. SDP:n eduskuntaryhmä katsoi, että näin radikaaleihin uudistuksiin vaadittiin takautuvia säädöksiä, jotka muuttaisivat vallitsevia oikeussuhteita. Vaikka Suomessa ei ollut kehittynyt varsinaista maaorjuutta, niin täälläkin oli ollut vastaava isännän ja alustalaisten välinen alistussuhde. Sosialidemokraatit kannattivat maanvuokraajien muuttamista tilojensa omistajiksi, koska omistusoikeus turvaisi - "niin varmasti kuin se yleensä kapitalistisessa yhteiskunnassa on mahdollista" - vuokramiehen tilaansa kiinnittämän pääoman ja työn "ryöstöpyyteiltä". Näin sekä toteutuisi maanvuokraajien etu että mahdollistuisi taloudellinen edistys. ${ }^{484}$

Vapauttamista ei kuitenkaan pitäisi toteuttaa maanomistajan ja maanvuokraajan keskinäisillä vapailla sopimuksilla, kuten porvarilliset ryhmät ajoivat. SDP:n mielestä tämä veisi maanvuokraajat entistäkin enemmän maanomistajien mielivallan alaiseksi. Sen sijaan se halusi säädettävän tarkat perusteet, joiden mukaan vuokramiehillä oli oikeus lunastaa tilansa. Laissa olisi määrättävä yleiset perusteet lunastushinnan arvioimiseksi, joissa vähennettäisiin vuokramiehen työntulon, perinnön tai oston kautta hänelle jo kuuluva osuus. Esityksen mukaan normaalia suurempaa vuokraa maksaneiden vuokramiesten pitäisi saada ostaa tilansa halvemmalla. Kun maanvuokraajasta tehdään maanomistaja, pitää samalla lopettaa vuokramiehen metsänkäyttö- ja laidunoikeus talon

4831912 VP, anomusehdotus n:o 60, liitteet VIII, s.83-88.

4841912 VP, anomusehdotus n:o 60, liitteet VIII, s.88-92. 
mailla sekä irrottaa hänelle nautintaoikeuksia vastaava kappale maata. Jos se ei onnistu, menetettyjen etujen arvo tulisi vähentää ostohinnasta. Päätilaa seuraavista rasituksista vuokramiehelle jäävä osa pitäisi vähentää ostohinnasta. ${ }^{485}$

Sosialidemokraatit katsoivat, että jos maanvuokraaja ei pystynyt maksamaan ostohintaa heti, hänen pitäisi voida maksaa vähitellen kohtuullisella korolla. Valtio voisi toimia välittäjänä maksamalla maanomistajille ostohinnan ja keräämällä vähitellen varat maanvuokraajilta. Ongelmakohdat voitaisiin jättää puolueettomille lautakunnille, kuten esimerkiksi tuolloisille vuokralautakunnille. Maanvuokraajan päätettäväksi olisi jätettävä, milloin hän haluaa ostaa tilansa. Poikkeustapauksissa jätettäisiin maaomistajalle oikeus lunastaa vuokratila itselleen, jolloin vuokramies saisi korotetun korvauksen. Asian ratkaisemisen uskottiin vievän niin runsaasti aikaa, että vuoden 1909 taannehtivan asetuksen suomaa rauhoitusaikaa pitäisi jatkaa ainakin 20 vuodella. ${ }^{486}$

On kiinnostava huomata, että porvarillisen "tynkäeduskunnan" sisällissodan jälkeen toteuttama maanvuokraajavapautus muistutti periaatteiltaan tätä sosialidemokraattien tekemä anomusehdotusta. Sisällissodan jälkeen hyväksytty lunastuslaki ei ollut aivan yhtä radikaali kuin SDP:n ehdotus. ${ }^{487}$ 1910-luvun alkupuoliskolla sosialidemokraattien anomusehdotuksella ei kuitenkaan ollut mahdollisuuksia tulla hyväksytyksi. Porvarillisilla puolueilla oli noina vuosina eduskunnan valiokunnissa niukka - usein vain yhden äänen - enemmistö. Porvarilliset puolueet järjestivät ehdotusten käsittelyn usein niin, että sosialidemokraattien aloitteet joutuivat käsittelyjärjestyksen jälkipäähän ja niiden käsittely jäi siten valiokunnissa kesken. ${ }^{488}$ Tämä oli SDP:n vuoden 1912 maanvuokra-aloitteenkin kohtalo maatalousvaliokunnassa.

Vuoden 1912 valtiopäivilläkin sosialidemokraatit puolestaan äänestivät määrävähemmistönsä turvin porvarillisten ryhmien

4851912 VP, anomusehdotus n:o 60, liitteet VIII, s.92-98.

4861912 VP, anomusehdotus n:o 60, liitteet VIII, s.98-101.

487 Rasila 1970, s.389.

488 Rasila 1970, s.165. 
maanvuokraajakysymystä koskevan anomusehdotuksen maanvuokraajakysymyksen yli vaalien. Porvarillisten ryhmien ehdotus oli saman sisältöinen kuin edellisillä valtiopäivillä. Tälläkin kertaa useat porvarilliset edustajat jättivät vastalauseensa sosialidemokraattien menettelyn takia. ${ }^{489}$

Valtiopäivillä käytiin maaliskuussa 1912 perinpohjainen keskustelu maanvuokraolojen järjestämisessä. Gylling mukaan feodaaliselle pohjalle rakentuva maanvuokrajärjestelmä oli hajoamassa, kun se joutui vastakkain uuden kapitalistisen kehityksen kanssa. Hän katsoi, ettei kapitalistinen suurviljelijä tyytynyt toimintavapauttaan rajoittavaan maanvuokrajärjestelmään vaan suurviljelyksen kehittyessä lisääntyivät maanvuokraajien häädöt, joita lisäsi myös metsän arvonnousu ja metsäkapitalismin kehitys. Maanvuokraajien asema näytti jäävän tämän kehityksen aikana sietämättömän huonoksi ja epävarmaksi. Gyllingin mukaan myös lainsäädännöllä oli ennemminkin huononnettu kuin parannettu maanvuokraajien asemaa. Vuoden 1909 lailla maanvuokraajien asema tosin vakiinnutettiin vuoteen 1916 asti mutta sen jälkeen heidän asemansa oli kuitenkin vähintään yhtä huono kuin ennenkin. Gyllingin mielestä maanvuokraajien tekeminen maanomistajiksi olisi edistysaskel, jos sitä ei toteutettaisi maanomistajien ja maanvuokraajien vapailla sopimuksilla, jotka antaisivat edelliselle määräysvallan. ${ }^{490}$

Suomalaisen Puolueen J. K. Paasikivi (1870-1956) oli kuulunut sosialidemokraattien viljelyspakkoajatuksen johdonmukaisempiin arvostelijoihin ${ }^{491}$. Hän iloitsikin siitä, että SDP oli luopunut tuollaisesta "humbuugista" ja siirtynyt tukemaan pienviljelystä. Gylling vastasi tähän, ettei SDP halunnut edistää pienviljelystä vaan se halusi lakkauttaa maanomistajien ryöstöoikeuden. ${ }^{492}$

489 Rasila 1970.s.120.

4901912 VP, ptk., s.93-96.

491 Immonen, Hannu, Agraaripoliitikko. Teoksessa Polvinen, Tuomo, Heikkilä, Hannu - Immonen, Hannu, J. K. Paasikivi. Valtiomiehen elämäntyö 1, 1870-1918. Juva 1989, s.160.

4921912 VP, ptk., s.96-99. 
Sosialidemokraatit katsoivat vuoden 1912 valtiopäivillä, että porvarilliset ryhmät pyrkivät viivyttämään maanvuokraajien asian ratkaisemista. Gylling ilmoitti tyytyväisyytensä siitä, että hallitus oli viimeinkin alkanut koota tilastollista aineistoa maanvuokraajien oloista mutta katsoi, että tulosten odottaminen hidastaisi liikaa asian käsittelyä. Porvarilliset edustajat kielsivät pyrkimyksen haudata vuokramiesten ongelmat. ${ }^{493}$

Vuoden 1912 valtiopäivien päättyessä porvarillinen enemmistö oli jäädyttänyt SDP:n anomusehdotuksen ja sosialidemokraattinen määrävähemmistö oli äänestänyt porvarillisten ryhmien anomusehdotuksen yli vaalien. Tässä poliittisesti voimakkaasti jakautuneessa pattitilanteessa maanvuokraajien asema jäi edelleen ratkaisematta.

SDP:n eduskuntaryhmä uudisti anomusehdotuksensa maanvuokraajille myönnettävistä oikeuksista ja vuokraolojen järjestämisestä vuoden 1913 valtiopäivillä. Gylling oli jälleen esityksen ensimmäinen allekirjoittaja. Johdannossa valitettiin sitä, ettei ehdotus tullut edellisillä valtiopäivillä käsitellyksi loppuun eikä maatalousvaliokunnassa edes valmistelevan käsittelyn alaiseksi. Siinä pidettiin kuitenkin myönteisenä sitä, että hallitus aloitti tilastojen keräämisen maanvuokraajien oloista ja asetti komitean tutkimaan kysymystä. Sosialidemokraattien mielestä oli kuitenkin valitettavaa, että komiteassa oli lähes pelkästään maanomistajien edustajia, mikä ilmeni muun muassa siinä, että komitean jättämässä mietinnössä asiat pyrittiin järjestämään aivan toisin kuin SDP:n ehdotuksessa. Tämän "vuokramiesten oikeuksia räikeästi loukkaavan" esityksen vastapainoksi SDP:n eduskuntaryhmä uudisti oman ehdotuksensa. Vuoden 1913 anomusehdotus oli hieman tiivistetty versio edellisen vuoden ehdotuksesta. Asiallisia eroja ei ollut. ${ }^{494}$

Lokakuussa 1912 senaatin talousosaston kokouksessa perustettiin maanvuokrakomitea, jonka puheenjohtajaksi tuli A. O. Kairamo. Komitea edusti eri puolueryhmittymiä, joskaan ei suh-

4931912 VP, ptk., s.176-181.

4941913 VP, anomusehdotus n:o 60, liitteet VIII, s.687-700. 
teessa niiden valtiopäiväedustukseen. Suomalainen Puolue sai puheenjohtajan lisäksi kolme paikkaa, Ruotsalainen Kansanpuolue tuli kolme paikkaa ja muut puolueet saivat kaksi paikkaa. SDP:n edustajiksi komiteaan tulivat Gylling ja Tokoi. ${ }^{495}$

Maanvuokrakomitea keskusteli maanvuokrakysymyksen lopullisesta ratkaisemisesta, mutta samalla sen jäsenet olivat tulleet vakuuttuneeksi siitä, ettei mitään lopullista järjestelyä saataisi aikaan ennen vuoden 1916 maaliskuuta, mihin saakka vuokrasuhteet oli jäädytetty. Komitea ehdottikin helmikuussa 1913 antamassa mietinnössään takautuvan asetuksen jatkamista viidellä vuodella, jolloin vuonna 1916 päättyvät vuokrasopimukset jatkuisivat vuoteen 1921. Tavoitteena oli saada uusi takautuva asetus vireille jo vuoden 1913 valtiopäivillä. Komitean ehdotuksen mukaan vuokraehtoja oli kuitenkin voitava muuttaa, mikäli niiden jatkaminen sellaisenaan aiheuttaisi maanomistajalle selvää vahinkoa eikä olisi yleisenkään edun kannalta järkevää. Vuokrasuhteen jatkaminen ei olisi saanut lainkaan koskea sellaisia vuokratiloja, joiden yhdistäminen päätilan viljelyksiin oli hyvin järjestetyn maanviljelyksen kannalta välttämätöntä tai jos vuokra-aluetta tarvittiin teollisuuslaitoksen tarkoituksiin. ${ }^{496}$

Komiteamietintö oli lähellä vanhasuomalaista linjaa. RKP:n Ivar Björkvik jätti vastalauseensa, koska hän ei hyväksynyt laillisia oikeuksia loukkaavia takautuvia lainsäädäntötoimia. Toisen vastalauseen jättivät Gylling ja Tokoi. He yhtyivät komiteaan kantaan, että voimassa olevia vuokrasuhteita pitäisi pidentää viidellä vuodella. He eivät kuitenkaan hyväksyneet muutoksia vuokrasuhteisiin, paitsi jos päätilalla toimeenpantiin metsänhoitosuunnitelma. Siinä tapauksessa maanvuokraajan metsänkäyttöoikeutta voitiin supistaa, jos samalla vuokraa laskettiin. Heidän mielestään vuokrasuhteisiin pitäisi tehdä vain välttämättömät muutokset, ettei

495 Rasila 1970, s.140-141. Komitean muut jäsenet olivat maanviljelysneuvos H. G. Paloheimo, professori K. J. Ståhlberg, vapaaherra O. Wrede, senaattori J. K. Paasikivi, pankinjohtaja E. Schybergson, agronomi K. V. Koskelin, Ikaalisten tuomiokunnan tuomari A. I. Björnvik, maanviljelijä T. Junnila, maanviljelijä O. Lahdensuo ja lakitieteiden kandidaatti K. Haataja.

496 Komiteamietintö 1/1913; Rasila 1970, s.141-142. 
lainsäätäjän käsiä sidottaisi lopullisen järjestelyn toteuttamisessa. Ei saisi myöskään riistää maanvuokraajan raivaustyöhön perustuvia oikeuksia. ${ }^{497}$

Vaikka senaatin esitys ennätti eduskuntaan vasta maaliskuun lopulla, maanvuokrakomitean puheenjohtajan A. O. Kairamo nosti maanvuokrakysymyksen esille siellä jo helmikuussa 1913. Myös oikeistolla ja sosialidemokraateilla oli omat aloitteensa asiasta. Gylling otti syntyneessä eduskuntakeskustelussa asiaan jälleen voimakkaasti kantaa ja erotteli kolme suuntausta. Nuorsuomalaisten Jonas Castrénin (1850-1922) ja Heikki Renvallin (1872-1955) aloite merkitsisi olojen palauttamista pääosin sille kannalle, joka vallitsi ennen vuoden 1909 maanvuokraaja-asetusta. Toisena suuntauksena oli Kairamon esitys, joka oli erittäin lähellä maanvuokrakomitean anomusehdotusta: molemmissa vaadittiin taannehtivan asetuksen pidentämistä ja pitkällä tähtäimellä pyrittiin maanviljelijöiden lukumäärän lisäämiseen. Gyllingin mukaan tämä tosin koskisi vain pientä osaa maanvuokrajista ja supistaisi maanvuokraajien oikeuksia. Kolmantena on sosialidemokraattien aloite, jota maatalousvaliokunta ei vuoden 1912 valtiopäivillä suostunut käsittelemään mutta joka uudistettiin vuoden 1913 valtiopäivillä. Tässä keskeisenä sisältönä oli se, että maanvuokraajat voisivat säädellyillä ehdoilla lunastaa vuokratilan omakseen jopa ilman maanomistajan suostumusta. ${ }^{498}$

Gyllingin puheenvuoron pohjalta syntyi vilkas keskustelu. Suomalaisen puolueen, maanvuokrakomitean puheenjohtajana toiminut Kairamo viittasi Hannes Gebhardin tutkimuksiin ja puolusti luonnollisesti komitean ajamaa pienviljelyksen tukemista. Nuorsuomalaisten edustaja Jonas Castrén puolestaan kielsi Gyllingin väitteen, jonka mukaan hänen ja Renvallin ehdotus palauttaisi tilanteen vuotta 1909 edeltäneeseen aikaan. Castrénin mielestä silloista maanvuokralakia oli muutettava ja maanvuokraajien pääsemistä maanomistajiksi helpotettava. ${ }^{499}$

497 Komiteamietintö 1/1913, s.11-13.

4981913 VP, ptk., s.108-110.

4991913 VP, ptk., s.110-112. 
Vastalauseista huolimatta senaatti laati ehdotuksen armolliseksi esitykseksi miltei maanvuokrakomitean mietinnön mukaisena ja esitti asian käsittelemistä perustuslain mukaisessa järjestyksessä. Maaliskuussa 1913 keisarin allekirjoittama esitys vuokrasuhteiden jatkamisesta saapui senaattiin ja esiteltiin eduskunnalle. ${ }^{500}$

Eduskunnassa käytiin huhtikuun 1913 alussa senaatin esityksestä vilkas lähetekeskustelu lähinnä kahden porvarillisen suuntauksen välillä. Vanhasuomalaisten selvä enemmistö kannatti esitystä, mutta oikeiston piirissä sitä vastustettiin. SDP vastusti myös esitystä. Lähetekeskustelussa puhuneen Gyllingin mukaan kaikkia porvarillisia ryhmiä pelotti se, että vuonna 1916 joudutaan laatimaan uuden vuokralain mukaisia sopimuksia niille maanvuokraajille, joita maanomistajat eivät voineet häätää. Hän totesi, että porvarien oli vaikea tappaa "lypsylehmäänsä, jona torpparilaitos vuosisatojen kuluessa on heille ollut". Gylling katsoi, ettei vanhasuomalaisten linja poikennut paljoakaan oikeiston pyrkimyksistä, joskin se reaalipoliittisista syistä oli muodollisesti maltillisempaa. Molemmat pyrkivät kuitenkin jättämään maanviljelijälle vapauden häätää maanvuokraajat tai korottaa vuokraa. ${ }^{501}$

Kairamo arvosteli Gyllingin näkemystä. Hänen mukaansa keskusta ja oikeisto olivat usein samaa mieltä, mutta monessa asiassa myös erimielisiä. Ongelmana oli se, että maanomistajien ja maanvuokraajien vaatimukset olivat monessa kohtaa aivan vastakkaisia, eikä kompromisseille tuntunut löytyvän mahdollisuutta. Kairamo syytti tästä lähinnä sosialidemokraatteja. ${ }^{502}$

Gylling ehdotti, että kaikki vuokrasopimukset jatkettaisiin sellaisenaan vähintään vuoteen 1919, mikäli maanvuokraaja ei tätä vastustaisi. Ehdotusta kannattivat kuitenkin ainoastaan sosialidemokraatit, joten se hylättiin. Tämä sai Gyllingin epäilemään sitä, että porvarilliset puolueet pyrkivät vapautumaan silloisen vuok-

500 Rasila 1970, s.141-143.

5011913 VP, ptk., s. 313-314; Rasila 1970, s.152-153.

5021913 VP, ptk., s.319-321; Suomalaisen Puolueen puoluekokouksessa Kairamo tosin katsoi oikeaksi sosiaalidemokraattien väitteen, jonka mukaan esityksessä oli huolehdittu ennen kaikkea maanviljelijöiden eduista. KA, Suomalaisen Puolueen Arkisto, puoluekokouksen ptk. 2-3.5.1913. 
ralain määräyksistä, mutta useat porvarilliset edustajat kielsivät väitteen. ${ }^{503}$

SDP:n eduskuntaryhmä julkaisi lehdistössä avoimen kirjeen maanvuokraajille. Siinä pyydettiin maanvuokraajia pitämään kokouksia ja ottamaan kantaa komitean ehdotukseen. Maaliskuun lopulla ja huhtikuun alussa ympäri maata pidettiin useita kokouksia, missä kehotettiin SDP:n eduskuntaryhmää äänestämään esitystä vastaan. ${ }^{504}$

Asia nousi esille myös Tampereella 21.-22.4.1913 pidetyssä maanvuokraajien valtakunnallisessa edustajakokouksessa. Tokoi ja Gylling olivat kysymyksestä eri mieltä. Tokoin mielestä laki ei vaikuttanut silloisiin oloihin kovin suuresti. Tärkeintä oli estää maanomistajia tekemästä joukkohäätöjä vuonna 1916. Tästä syystä olisi jäätävä odottavalle kannalle ja pyrittävä lisäämään SDP:n voimaa. Hänen mielestään jatkamisesitystä ei pitäisi hylätä, vaan äänestää lepäämään. Gylling korosti sitä, että takautuva lakiehdotus varmistaisi viiden vuoden vuokra-ajan pidennyksen vain pienelle osan maanvuokraajista. Se nimittäin antaisi maanomistajille mahdollisuuden häätää ne vuokramiehet, joiden tila oli niin lähellä päätilaa, että ne voitiin ottaa yhteisviljelykseen. Sitä paitsi tuon viiden vuoden aikana maanomistajat voisivat heikentää vuokramiehen asemaa entisestään. Jos taannehtivaa lakia ei jatketa, ei hänen mukaansa ollut odotettavissa kovin paljoa häätöjä, koska ne pitäisi suorittaa vuoden sisällä. Gyllingin mielestä ei pitäisi jäädä Tokoin ehdottamalle odottavalle kannalle, koska perääntyminen rohkaisisi maanomistajia hyökkäykseen. Asiasta käytettiin lukuisia puheenvuoroja, joissa yleensä kallistuttiin ehdotuksen hylkäämisen kannalle. Lopulta hyväksyttiin päätöslauselma, jonka mukaan lainsäädännön perustana pitäisi olla, ettei yhtään maanvuokraajaa saa häätää tai vähentää heidän oikeuksiaan. Koska komitean ehdotus syrjäytti tämän lähtökohdan, joten sen läpimeno pitäisi estää. Kokous hyväksyi tämän kannan

5031913 VP, ptk., s.771-789.

504 Rasila 1970, s.143-150. 
numeroin 208-22. ${ }^{505}$ Gylling sai siis linjalleen kokouksen selvän enemmistön tuen.

Loppujen lopuksi senaatin esitys vuokrasuhteiden jatkamisesta hylättiin eduskunnassa selvin numeroin 131-53. Tämä tapahtui oikeiston ja vasemmiston äänin, joiden perustelut hylkäämiselle olivat kuitenkin vastakkaiset. Monien Ruotsalaisen kansanpuolueen ja nuorsuomalaisten edustajien mielestä maanomistajan rajoittamaton oikeus maansa suhteen oli ehdoton periaate, jota uusi takautuva asetus rajoittaisi liikaa. Sosialidemokraatit taas katsoivat, että se mahdollistaisi maanomistajan mielivallan maanvuokraajiaan kohtaan. ${ }^{506}$ Sosialidemokraattisen puolueen sisällä Tokoi oli ollut kysymyksessä kahden vaiheilla ja valmiimpi kompromissiin kuin Gylling. Kuitenkin Gyllingin johdolla sosialidemokraatit kallistuivat esityksen hylkäämisen kannalle.

Elokuussa 1913 suoritetuissa eduskuntavaaleissa SDP sai neljän paikan vaalivoiton. Tämän jälkeen eduskunnassa oli 110 porvarillista edustajaa ja 90 sosialidemokraattia. Seuraavien säännöllisten vaalien aika oli vasta elokuussa 1916, joten tämän eduskunnan oli ratkaistava maanvuokrakysymys, jos se tahdottiin ratkaista ennen vuokrasuhteiden jäädytyksen päättymistä ennen saman vuoden maaliskuussa. Vuonna 1914 uskottiin kuitenkin, ettei asialla vielä ollut polttava kiire, koska sitä ehdittäisiin käsitellä vielä vuosina 1915 ja $1916 .{ }^{507}$

Vuosien 1911 ja 1912 valtiopäivillä SDP oli äänestänyt porvarillisten ryhmien ajamat asetukset pientiloista ja maalaisväestön asutusrahastoista lepäämään yli vaalien. Vuoden 1914 valtiopäivillä nämä esitykset tulivat lopullisesti hyväksyttäväksi tai hylättäväksi. Sosiaalidemokraatit asettuivat esityksiä vastaan, koska ne sitoivat piiriinsä myös maanvuokraajat, joita varten he halusivat aivan oman lainsäädäntönsä. ${ }^{508}$

505 Maanvuokraajien viidennen yleisen edustajakokouksen ptk. Tampere 1913, s.14-20.

5061913 VP, ptk., s.962; Rasila 1970, s.153.

507 Rasila 1970, s.184.

508 Rasila 1970, s.184-185. 
Gylling piti asiaa käsiteltäessä puheenvuoron, joka laajeni teoreettisiin näkemyksiin maatyöväen ja maanvuokraajien asemasta. Hänen mukaansa varsinaisen tilattoman väestön ja maanvuokraajien asema kuuluivat samaan kokonaisuuteen, mutta silti näiden ryhmien oloissa ja tulevassa kehityksessä oli merkittäviä eroja. Varsinainen tilaton väestö oli kapitalistisen kehityksen luoma, eikä sitä esiintynyt paljoakaan ennen 1800-luvun puoliväliä. Marxia lainaten Gylling totesi että tämä kehityshistoria oli kirjoitettu verellä. Jokaisen maan alkukapitalismin kehitykseen kuului tilattoman väestön synty. Saman luonnonlakia muistuttava välttämättömyyden mukaan se vähitellen siirtyi kaupunkeihin. Suomessa tämä kehitys ei ollut vielä päässyt pitkälle. Vaikkei tämän väestönosan elämä kaupungissa ole helppoa, merkitsi siirtyminen ammattityöväen joukkoon sille kuitenkin selvää parannusta. Lisäksi se merkitsi edistystä työväen luokkataistelun kannalta. Gylling korosti, että lainsäädännön tulisi perustua taloudellisen kehityksen viitoittamalle pohjalle. Kuitenkin porvarillisten puolueiden lakiehdotukset pyrkivät lisäämään pienviljelijöiden lukumäärää ja sitomaan heidät lainoilla maahan pitkäksi aikaa. Gyllingin mielestä tämä oli huonoa politiikkaa tilattoman väestön kannalta ja vielä suuremmassa määrin maanvuokraajien kannalta. ${ }^{509}$

Gyllingin mukaan maanvuokraajaluokka oli jäänne feodalismista, joten sen asema poikkesi olennaisesti tilattoman väestön asemasta. Hän totesi, että maanvuokraajien ongelmat pitäisi ratkaista vapauttamislainsäädännön avulla, mutta porvarilli-set edustajat halusivat pitää asian vapaaehtoisuuden pohjalla. Valtiolla ei kuitenkaan olisi läheskään tarpeeksi varoja toteuttaa vapautusta lainoilla, joten eduskunnan pitäisi hylätä ehdotetut toimenpiteet ja keskittyä maanvuokraajien vapauttamiseen. Gyllingin mielestä porvarilliset puolueet olivat kuitenkin taloudellisen taantumuksen puolella, eivätkä halunneet toteuttaa tätä sinänsä porvarillista reformia. ${ }^{510}$

5091914 VP, ptk., s.376-380.

5101914 VP, ptk., s.380-382. Markkola - Östman 2012, s.38. 
Gylling kutsui yhteiskunnan kehitystä luonnonlainomaiseksi välttämättömyydeksi. Hän seurasi tässä varsin puhtaasti marxilaista historianfilosofista teoriaa sen kautskylaisessa, varsin fatalistisessa muodossa. Gyllingin argumentoinnin painopiste oli vuosien varrella siirtynyt selkeästi historiallisesta kansantaloustieteestä marxilaiseen näkemykseen, jossa historiaa vie eteenpäin luokkataistelu. Maatalouden kehitystä kuvatessaan hän käytti marxilaisesti käsitteitä "feodalismi" ja maanvuokraajaluokka". Gyllingin aiemmin esittämät revisionistiset varaukset olivat hävinneet ja argumentoinnin retoriikka koventunut. Toisaalta hänen kirjoituksissaan näkyi edelleen vahva usko tilastoihin ja empiiriseen tutkimukseen.

Seuranneessa keskustelussa porvarillisten puolueiden edustajat korostivat sitä, että maanviljelys pysyy vielä pitkään Suomen keskeisimpänä elinkeinona ja pienviljelijäksi pääsemisen parantaisi tilattoman väestön asemaa. Tosin myös porvarilliselta puolelta katsottiin, että aivan pieniä tiloja oli muodostettu liikaa. Nuorsuomalainen Rudolf Holsti (1881-1945) arvosteli Gyllingin käyttämää marxilaista mallia liian yksipuoliseksi ja luonteeltaan lähinnä uskonkysymykseksi. Vanhasuomalainen Antti Tulenheimo (1879-1952, vuoteen 1906 Thulé) säesti Holstia ja totesi, etteivät taloudelliset lait ole yhtä ehdottomia kuin luonnonlait. SDP:n vastustuksesta huolimatta kauan vireillä olleet asutuslait hyväksyttiin maaliskuussa 1914 porvarillisten edustajien äänillä. ${ }^{511}$

Maanvuokrakomitea päätti erinäisten keskustelujen jälkeen jatkaa työtään eduskunnan hylkäävän päätöksen jälkeenkin. Kesäkuussa 1914 komitea antoi lopullisen mietintönsä, missä pyrittiin itsenäistämään suurin osa maanvuokraajista. Laaja mietintö käsittää kaiken kaikkiaan 218 sivua. Sen alussa luodaan katsaus maanvuokrajärjestelmän historialliseen kehitykseen sekä selostetaan maanvuokraoloissa vallinneita epäkohtia sekä yrityksiä niiden parantamiseksi vuosien 1902 ja 1906 lakien avulla. Tämän jälkeen analysoidaan sitä, mitä on odotettavissa vuonna $1916 .{ }^{512}$

5111914 VP, ptk., s.383-401.

512 Komiteamietintö 4/1914, s.40-56; Rasila 1970, s.154-160. 
Maanvuokrakomitean mietinnön mukaan maanomistaja saisi valita, jäisikö tila vuokralle vai olisiko maanvuokraajan lunastettava se. Jos yksimielisyyttä ei syntyisi, lunastushinta määrättäisiin kaksikymmentä kertaa niin suureksi kuin alueesta määritelty kohtuullinen vuosivuokra. Kuten edellisessäkin ehdotuksessa, toisessa pykälässä lueteltiin kuitenkin eräitä poikkeuksia, joiden perusteella vuokratila voitiin yhdistää päätilaan. Tällaisia poikkeuksia olivat jälleen lähinnä teollisuuslaitoksen tarpeet tai hyvän maanviljelyksen vaatimukset. Osapuolet saisivat vapaaehtoisesti sopia lunastussummasta ja muista ehdoista. Vuoden 1909 maanvuokra-asetus olisi uudistettava järjestelyn ulkopuolelle jääviä vuokrasuhteita varten. ${ }^{513}$ Mietintö noudatteli edeltäjänsä tavoin lähinnä sosiaalireformistista, vanhasuomalaisia lähellä olevaa linjaa.

RKP:n edustaja Ivar Björnvik ei hyväksynyt maanomistajan oikeuksia rajoittavia toimenpiteitä ja jätti jälleen mietintöön vastalauseensa. Myös SDP:n edustajat Gylling ja Tokoi jättivät vastalauseen, joka perustui pitkälti samoihin seikkoihin kuin SDP:n vuosien 1912 ja 1913 valtiopäiville jättämä aloite. Gyllingin ja Tokoin mukaan oli tosiasia, että "torppariluokka" pitää hallussaan pitkien aikojen kuluessa raivaamiaan ja asumiaan alueita, mikä antoi heille oikeuden hallita niitä edelleen. Tästä johtuen maanvuokraajan asema pitäisi olla komitean esittämää parempi muun muassa siten, että hänen pitäisi voida ratkaista siirtymisestä maanomistajaksi ja saatava edullisemmat lunastushinnan määräysperiaatteet. He pitivät myös toisen pykälän poikkeusmahdollisuuksia epäoikeudenmukaisena. Erimielisyyttä oli myös syntyvien ristiriitojen ratkaisemisesta. Komitean mielestä ristiriidat oli jätettävä maanjako-oikeuksien ratkaistavaksi, joissa oli kuitenkin virkamiesten lisäksi vain maanomistajien edustajia. SDP:n mielestä niihin pitäisi lisätä maanomistajien edustajia vastaava määrä maanvuokraajien valitsemia jäseniä. Gylling ja Tokoi vastustivat myös komitean metsälakiin esittämää muutosehdotusta,

513 Komiteamietintö 4/1914, s.57-59, 71-72, 145-162. 
koska siinä vähennettiin korvauksetta maanvuokraajien oikeuksia. $^{514}$

SDP:n edustajat arvostelivat vuoden 1914 valtiopäivillä varsinkin lakiehdotuksen toista pykälää, jossa laajennettiin maanomistajan oikeutta häätää torpparinsa. Toinen pykälä lähetettiin käsiteltäväksi maatalousvaliokuntaan, missä sitä lievennettiin. Sen jälkeen toista pykälää käsiteltiin suuressa valiokunnassa, missä se yllättäen putosi kokonaan pois. Tämän jälkeen sosialidemokraatit suostuivat kannattamaan lakiehdotusta, mutta suurin osa vanhasuomalaisista äänesti sitä vastaan, jolloin se jäi lepäämään yli vaalien. $^{515}$

Gyllingin saavuttavaa asemaa SDP:n maatalouspolitiikan johtavana asiantuntijana kuvastaa se, että hän oli jälleen ensimmäinen allekirjoittaja, kun puolueen eduskuntaryhmä uudisti vuonna 1914 anomusehdotuksensa maanvuokraajien vapaaksi ostosta ja vuokralainsäädännön järjestämisestä. Ehdotuksen mukaan porvaritkin olivat ymmärtäneet sen, että maanvuokraajakysymyksen ratkaiseminen oli välttämätöntä. Ehdotus oli SDP:n vaihtoehto maanvuokraajakomitean mallille, joka sen mukaan tarjosi vain huonot ehdot osalle maanvuokraajista. ${ }^{516}$ SDP:n aloite jäi jälleen maatalousvaliokunnassa käsittelemättä.

Gylling uskoi huhtikuussa 1914, että maanvuokraajien asema pian parantuisi, koska porvarillisellakin taholla suunniteltiin viimein uudistuksia. Huhuista huolimatta hän ei sen sijaan odottanut venäläisiltä mitään apua maanvuokraajien aseman parantamisessa. Hän katsoi, että ansio mahdollisista uudistuksista kuului viime kädessä maanvuokraajien järjestäytymiselle ja painostukselle. ${ }^{517}$ Gylling totesi kesällä 1914 optimistisesti, että maanvuokraajakysymyksen lopullinen ratkaisu olisi pian edessä. Ensimmäisen

514 Komiteamietintö 4/1914, s. 206-218.

515 Rasila 1970, s.186-188. Ilmeisesti toinen pykälä hylättiin suuressa valiokunnassa, koska ruotsalaisen puolueen Rosenqvist oli SDP:n edustajien kanssa samaa mieltä ja pari edustajaa oli pois. Näin ollen arpa ratkaisi kysymyksen siten, että toinen pykälä jätettiin pois lakiehdotuksesta.

5161913 VP, Anomusehdotus n:o 78, liitteet VII.

517 Gylling, Edvard, Torppariasiain uusin vaihe, Työmies 17.7.1914 (A). 
maailmansodan puhkeaminen johti kuitenkin lainsäädäntötyön keskeytymiseen kolmeksi vuodeksi. Jää arvoitukseksi, olisiko näinä vuosina päästy kysymyksessä ratkaisuun ilman sodan syttymistä.

Vuonna 1915 Gylling kirjoitti ahkerasti Työmieheen torpparikysymyksestä. Hän oli huolissaan torppareiden lisääntyneistä irtisanomisista, joiden hän uskoi seuraavana vuonna moninkertaistuvan. ${ }^{518}$ Gylling myös arvosteli edelleen maanvuokrakomitean mietintöä, jonka toteuttaminen antaisi jonkinlaista lainsäädännöllistä turvaa ainoastaan alle puolelle mäkitupalaisista ja torppareista kun taas enemmistö heistä "tulisi jätettäväksi maanomistajain saaliiksi". ${ }^{519}$

Gylling syytti maanvuokrakomiteaa siitä, ettei se niinkään ajanut torpparien asiaa, vaan yritti lisätä pienviljelijöiden lukumäärää. Tämäkin tavoite tosin epäonnistuisi, mikäli tarpeeksi suuri osa torppareista häädettäisiin. ${ }^{520}$ Maanvuokrakomitea halusi tuntuvasti supistaa torpparin metsänkäyttöoikeutta, mikä Gyllingin mukaan johtaisi siihen, että torpparit joutuisivat vähentämään karjaansa ja ostamaan puuta. Tämän jälkeen torppari olisi edelleen riippuvainen entisestä isännästään. ${ }^{521}$ Gylling vastusti sekä taloudelliselta että inhimilliseltä kannalta mietinnön ajatusta, jonka mukaan maanomistaja saattoi ottaa torpista kymmenen hehtaaria ylittävän osan. Maanvuokrakomitea perusteli toimenpidettä siten, että torpparilla oli usein enemmän maata kuin hän pystyi viljelemään. Gyllingin mielestä tällaisessa tilanteessa torpparillakin pitäisi olla päätösvaltaa. ${ }^{522}$

518 Gylling, Edvard (nimim. E.G.), Torpparikysymyksen tila. Työmies 22.1. 1915 (C.).

519 Gylling, Edvard, (nimim. E.G.), Torppariolojen lopullinen järjestely. Maanvuokrakomitean ehdotuksen pääpiirteet. Työmies 22.1.1915 (D).

520 Gylling, Edvard, (nimim. E.G.), Ajaako maanvuokrakomitea torpparien asiaa. Työmies 28.1.1915 (E).

521 Gylling, Edvard, (nimim. E.G.), Tarvitseeko torppari metsä ja laidunmaata? Työmies 23.3.1915 (H).

522 Gylling, Edvard, (nimim. E.G.), Torpparien viljelysmaat. Onko niitä vähennettävä? Työmies 10.4.1915 ja 12.4.1915 (I.). 
Gyllingin mukaan sosialidemokraattien päämääränä oli lainsäädäntö, jolla torppareista tehtäisiin tilojensa omistajia ${ }^{523}$ ja samalla hävitettäisiin feodalismi, joka antoi kartanonherroille tilaisuuden alistaa alustalaisiaan ja häiritsi maataloustekniikan kehitystä. Hän uskoi porvarillistenkin puolueiden uudistushalukkuuden lisääntyneen. Tästä esimerkkinä oli ennen kaikkea maanvuokrakomitean mietintö, joka tosin puolusti enimmäkseen maanomistajien etuja. Gylling kuitenkin varoitti, että osa oikeistosta halusi käyttää sotatilaa tekosyynä perääntyä tästäkin uudistuksesta. ${ }^{524}$

Tyytyväisenä Gylling saattoi todeta, että oli alettu kerätä tietoja irtisanottujen maanvuokraajien määristä. Hänen mukaansa tilastosta näkyisi tilanteen vakavuus, mikä taas edistää torpparivapautusta. ${ }^{525}$ Tässä käsityksessä näkyy vahva usko tilastoihin yhteiskunnallisen päätöksenteon ohjaajana.

523 SDP:n yleisestä linjasta poikkesi Aatto Sirén, joka vastusti torpparien itsenäistämistä pääteemanaan itsenäisen pienviljelyksen kannattamattomuus ja siihen liittyvä velkaorjuus. Hänen mielestään torpparin asema oli pienviljelijää turvatumpi. Sirén kirjoitteli asiasta aktiivisesti lehtiin aina syksylle 1916 asti. Ks. Rasila 1970, s.225-226.

524 Gylling, Edvard, (nimim. E.G.), Torpparikysymyksestä vieläkin. Työmies 4.3.1915 (F).

525 Gylling, Edvard, (nimim. E.G.), Torpparivapautuksesta. Työmies 17.3.1915 (G). 


\section{Yhteiskunnallisten aineiden ja historian opettaja}

Puolueopiston luennot historiakuvan avaajana

Vuodesta 1903 alkaen SDP järjesti maata kiertäville puhujilleen eli agitaattoreille kursseja. Suurlakon jälkeen korostettiin entistä voimakkaammin agitaattorien koulutuksen tarpeellisuutta. Lahdessa pidettiin vuoden 1906 lopulla valtakunnallinen kaksiviikkoinen agitaattorikurssi, jonka jälkeen siirryttiin järjestämään vaalipiireittäin vuosittaisia muutaman päivän mittaisia luentokursseja. Lisäksi ryhdyttiin suunnittelemaan erityisen puolueopiston perustamista. ${ }^{526}$

Puolueopiston perustaminen oli useita kertoja esillä puoluetoimikunnassa ja puolueneuvostossa. Vuoden 1908 alussa puoluetoimikunta valitsi komitean suunnittelemaan opiston perustamista. Puolueneuvosto valitsi siihen Gyllingin, Valppaan, Kuusisen ja K. Satamavuoren. Puolueopistokomitea antoi helmikuussa 1908 puolueneuvostolle mietinnön, minkä mukaan opisto voisi palvella agitaattorien lisäksi myös puoluelehtien toimittajien, puolueen ja ammattiyhdistysten luottohenkilöiden sekä yleensäkin nuorten puoluetoverien sosialidemokraattista sivistystarvetta. Komitea ehdotti, että vuosittain pidettäisiin noin 50 oppilaalle kolmen kuukauden kurssit ja varojen salliessa lisäksi jatkokursseja. ${ }^{527}$

526 Ehrnrooth 1992, s.190-199,211.

527 Kertomus SDP:n puoluetoimikunnan toiminnasta 26.8.1906-15.7.1909. Helsinki 1909, s.7-9; Suomen Sosialidemokraattisen Puolueen kuudennen edustajakokouksen pöytäkirja. Kotka 1909, (SDP:n VI PK), s. 7-9. Joka arkipäivä oli tarkoitus olla neljä tuntia luentoja ja kaksi tuntia harjoitusaineita. Esitelmiä oli tarkoitus olla seuraavista aiheista: sosialismin teoria ja historia 
Hankkeen rahoitus ja opettajaresurssien riittämättömyys osoittautuivat kuitenkin vaikeiksi ongelmiksi. Puolueneuvosto päättikin elokuussa 1908, että opiston perustaminen siirretään seuraavaan syksyyn. Sen sijaan Helsingin Työväenyhdistyksen talolla järjestettiin iltakurssit 22.11.-13.12.1908, joihin kuului kaikkiaan 70 tuntia luentoja. Valtaosa luennoitsijoista oli marraskuun sosialisteja: Gylling luennoi Suomen yhteiskuntataloudellisesta kehityksestä kymmenen tuntia. ${ }^{528}$ Iltakurssit olivat hyvää harjoitusta puolueopistoa ajatellen.

Vuoden 1906 puoluekokouksessa opistohanketta kannatettiin varsin yksimielisesti, mutta riittävää rahoitusta ei saatu koottua. Sen sijaan Kotkan puoluekokouksessa kolme vuotta myöhemmin opistohanke synnytti kiistaa: puoluejohto kannatti varauksetta puolueopistoa mutta kentällä sen tarpeellisuudesta oli suuria epäilyksiä. Lopulta opisto kuitenkin perustettiin ja puolueen kassasta varattiin sille 2000 markkaa. Puoluekokouksen jälkeen kokoontunut Suomen Ammattijärjestö (SAJ) päätti antaa toimikunnalle saman summan. Puoluetoimikunta valitsi lokakuussa 1909 opintokomiteaan puolueen edustajiksi Gyllingin, Kuusisen ja Turkian

(60 tuntia), Suomen yhteiskunnallistaloudellinen kehitys (50), kansainvälisen sosialidemokratian historia (20), ammattiyhdistysliike (30), valtio-oppi (20), finanssioppi (20), sosiaalipolitiikan eri aloilta, kuten maatalous-, kunnallis- työväensuojelupolitiikka (60), lainoppi (20), osuustoiminta (10) ja raittiusliike (5). Harjoitusaineita ajateltiin suoritettavan seuraavilta aloilta: puhe- ja esiintymisopetus, kokousten pito, ainekirjoitus, laskuoppi, kirjanpito ja sanomalehden toimitustyö.

528 SDP:n VI PK, s.8-10; Kertomus SDP:n puoluetoimikunnan toiminnasta 26.8.1906-15.7.1909. Helsinki 1909, s.10; Ehrnrooth 1992, s.215-216. Muut luennoitsijat ja aiheet olivat seuraavat: Sirola kansainvälisistä sosialistikongresseista (20 tuntia), Kuusinen kapitalismin kehityksestä ja sosialidemokratian periaatteellisesta ohjelmasta (21), A.B. Mäkelä kehitysopista (3), Julius Ailio maanpinnan muodostumisesta (2), Matti Turkia yhteiskunnallisesta vallankumouksesta (1), Jorma Järvinen uskontokäsitteiden kehityksestä (3), V. Vuolijoki maatalouden teknillisestä kehityksestä (2), S. Vuolijoki maatalouspolitiikan periaatteista (2) ja H. Vuolijoki historiallisesta materialismista (6). 
sekä ammattijärjestön edustajiksi Eero Haapalaisen (1880-1938), A. Räsäsen ja J. Pietikäisen. ${ }^{529}$

Toukokuussa 1910 komitea esitti, että puolueopiston toiminta voitaisiin aloittaa seuraavana syksynä. Samalla komitea esitti oppisuunnitelmansa. ${ }^{530}$ Suunnitelma poikkesi monessa kohtaa vuoden 1908 iltakurssien vastaavasta. Suurin ero oli, että opiston kurssi oli laajuudeltaan moninkertainen iltakurssiin verrattuna. Opintosuunnitelmassa oli luentoja 320 tuntia ja harjoitusaineita 115 tuntia, kun Helsingissä oli ollut vain 70 tuntia luentoja. Muun muassa luonnontieteet ja kehitysoppi oli jätetty pois mutta mukaan oli otettu opetusta tilastotieteestä sekä työväensuojelusta ja -vakuutuksesta. Gyllingillä oli todennäköisesti suuri vaikutus siihen, että nämä aiheet oli sisällytetty opetukseen.

Puoluetoimikunta hyväksyi mietinnön mutta luennoitsijoiden puute muodostui ongelmaksi. Päteviä luennoitsijoita ei saatu seuraaviin aloihin: maatalouspolitiikka, metsäpolitiikka, valtio-opin alkeet ja Suomen valtiollinen asema sekä valtiotalous, verotus ja kauppapolitiikka. Puolueen puheenjohtajalla Yrjö Sirolalla oli lisäksi opetuksen suunnittelussa vaikeuksia, jotka johtuivat erimielisyyksistä Kuusisen kanssa. Lopulta supistetustakin opetusohjelmasta jäi täyttämättä 43 luentotuntia. Haapalainen, Räsänen, Pietikäinen ja Turkia esittivät opiston aloittamista lyhennetyssä muodossa mutta Gylling ja Kuusinen vastustivat ajatusta. Kuusinen ilmoitti lisäksi, ettei suostunut luennoimaan taloushistoriasta

529 Kertomus SDP:n puoluetoimikunnan toiminnasta 13.9.1909-15.7.1911. Kotka 1911, s.1-2; Ehrnrooth 1992, s.216-218.

530 Kertomus SDP:n puoluetoimikunnan toiminnasta 13.9.1909-15.7.1911. Kotka 1911, s.3-4. Oppisuunnitelma käsitti seuraavat luennot: taloushistoriaa ja sosialismin historiaa (50 tuntia), Suomen yhteiskuntataloudellista historiaa (50), tilastotieteen perusteita (10), kansainvälisen työväenliikkeen historiaa ja sosialidemokraattisen menettelytavan perusteita (40), ammatillisesta työväenliikkeestä (50), valtio-opin alkeita (10), valtiontaloutta ja verotus- ynnä kauppapolitiikkaa (25), maatalous- ja metsäpolitiikkaa (20), kunnallissosialismia (15), työväensuojelusta ja -vakuutuksesta (25), lainopillisia neuvoja (20) ja osuustoiminnasta (5). Harjoitusaineissa oli seuraavat aihepiirit: ammatillinen kirjeenvaihto, työehtosopimusten laatiminen yms.. (15 tuntia), ainekirjoitusta (40), laskentoa (25), kirjanpitoa (25) ja puhetaitoa, sanomalehtityötä y.m.(10). 
ja sosialismin teoriasta, vaikka olikin aiemmin lupautunut. Myös Valpas kieltäytyi pitämästä luentoja. Vaikeudet johtivat jälleen opistohankkeen siirtymiseen. Luentokursseja kuitenkin järjestettiin eri puolella Suomea. Gylling ei luennoinut näillä kursseilla. ${ }^{531}$ Jari Ehrnroothin mukaan kiistassa oli viime kädessä kysymys valtataistelusta ja opillisesta puhtaudesta. Osa puoluejohdosta kuten Matti Turkia ja Matti Paasivuori olisivat hyväksyneet opiston luennoitsijoiksi myös revisionisteja. Siltasaarelaisille opiston aatteellinen puhtaus oli kuitenkin tärkeä, joten ainoastaan oikeaoppiset marxilaiset saivat luennoida. Kuusisen johdolla kautskylainen suuntaus voitti kiistan. ${ }^{532}$ Gylling ei ollut kiistassa kovin aktiivinen mutta vastusti opiston käynnistämistä tynkämuodossa, joten hänen voidaan katsoa asettuneen siltasaarelaisten puolelle.

SAJ:n toimikunta päätti opistohankkeen kariuduttua järjestää Helsingissä oman kuukauden kurssinsa, jonka ohjelma oli tiivis ja varsin teoreettinen. Vaikka Kuusinen oli kieltäytynyt luennoimasta puolueopistossa, hän luennoi SAJ:n kurssilla. Kuusinen ja Gylling luennoivat yhdessä taloustieteestä, minkä lisäksi Gylling luennoi myös tilastotieteestä. Kurssin ohjelma muistutti suunnittelultaan ja toteutukseltaan varsin paljon puolueopiston ohjelmaa. Helsingin puoluekokouksen jälkeen puoluetoimikunta valitsi uuteen opistokomiteaan puolueen edustajiksi Kuusisen, Gyllingin ja Turkian. SAJ:n toimikunta nimesi komiteaan edustajikseen Paasivuoren, J. Pietikäinen ja K. Vartiainen. ${ }^{533}$

531 TA, Yrjö Sirolan kirje puoluetmk.:1le 3.8.1910, kansio "puolueopisto 19101913"; Kertomukset SDP:n puoluetmk.:n toiminnasta 13.9.1909-15.7. 1911. Kotka 1911, s.5-6; Helsingin puoluekokouksessa Kuusista syytettiin monella taholla opistohankkeen siirtymisestä ja suoranaisesta juonittelustakin. Suomen Sosialidemokraattisen Puolueen seitsemännen edustajakokouksen pöytäkirja. Helsinki, ei painovuotta (SDP:n VII PK), s.35-36.

532 Ehrnrooth 1992, s.221-224.

533 Ala-Kapee Pirjo - Valkonen, Marjaana, Yhdessä elämä turvalliseksi 1. SAK:laisen ammattiyhdistysliikkeen kehitys vuoteen 1930. Helsinki 1982, s.258. Muut luennot olivat seuraavat: Voionmaa luennoi talousmaantieteestä, Yrjö Jahnsson työväen suojelusta, Haapalainen ammattiyhdistysliikkeestä, E. Torniainen Venäjän ja A. Halonen Yhdysvaltain ammattiyhdistysliikkeestä, Paasivuori ja Hilja Pärssinen sosiaalipolitiikasta sekä Väinö Hakkila 
Syksyllä 1911 puoluetoimikunta hyväksyi opistokomitean ehdotuksen, jonka mukaan puolueopisto toimisi supistetulla ohjelmalla joulukuun alusta tammikuun loppuun. Opistokomitea ja opettajat valitsivat opistoon 75 hakijasta 57. Valintakriteereitä ei ilmoitettu. Opiston ohjelma noudatteli melko tarkkaan komitean suunnitelmaa. Merkittävimmät muutokset olivat valtio-opin ja osuustoiminnan luentojen jääminen pois, edellinen ilmeisesti opettajan puutteen vuoksi. Gylling luennoi kuusi tuntia tilastotieteen perusteita, 12 tuntia maatalous- ja metsäpolitiikasta sekä 30 tuntia Suomen yhteiskuntataloudellisesta kehityksestä. Hänellä oli siis luentoja yhteensä 48 tuntia. $^{534}$

Vuonna 1912 opistokurssia ei järjestetty, koska luennoitsijatilanne ei ollut vieläkään hyvä. Syksyllä 1913 kurssi toteutettiin kolmen kuukauden mittaisena laajempana versiona: ohjelmaan ei kuitenkaan otettu uusia aineita, vaan laajennus tapahtui oppiaineiden sisällä. Luennoitsijat olivat sen sijaan osittain vaihtuneet. Gylling luennoi Suomen yhteiskuntataloudellisesta kehityksestä 39 tuntia, maatalous- ja metsäpolitiikasta 11 tuntia sekä tilastotieteen perusteista seitsemän tuntia. Hänellä oli siis yhteensä luentoja 57 tuntia eli yhdeksän enemmän kuin kaksi vuotta aiemmin. ${ }^{535}$

Kuusinen ja Gylling olivat opiston teoreettisesti johtavat opettajat, joskin myös Paasivuori luennoi paljon. Kuusinen toimi lisäksi

rikoslaista. Lisäksi kurssilla opetettiin kirjanpitoa, äidinkieltä, laskentoa, sanomalehtityötä, kokoustaitoa ja kirjastonhoitoa.

534 Ehrnrooth 1992, s.225, 510. Gyllingin luentojen lisäksi muut luennot puolueopistossa olivat seuraavat: Kuusinen luennoi talousoppia (35 tuntia) ja kansainvälisen sosiaalidemokratian historiasta (21 tuntia), Saxman, Lehokas, Heinonen ja Torniainen ammattiyhdistysliikkeestä (42 tuntia), Keto finanssioppia (17 tuntia) ja kunnallispolitiikasta (10 tuntia), Paasivuori työväensuojelus ja -vakuutus sekä lainsäädännöstä (24 tuntia) sekä Hakkila lainopillisia luentoja (14 tuntia).

535 Kuusinen luennoi talousopista tällä kertaa 51 tuntia, Keto finanssiopista 22 tuntia ja kunnallispolitiikasta 14 tuntia, Paasivuori luennoi aiheesta työväensuojelus ja -vakuutus sekä lainsäädäntö peräti 53 tuntia, Laaksovirta luennoi lainopillisia luentoja 18 tuntia sekä Haapalainen, Lumivuokko, Tokoi ja Elo luennoivat ammattiyhdistysliikkeestä 45 tuntia. Kuusinen luennoi yhdessä Wiikin ja Tynnin kanssa kansainvälisen sosialidemokratian historiasta 24 tunnin ajan. Ehrnrooth 1992, s. 226, 510. 
opiston hallinnollisena johtajana eli rehtorina. Gylling luennoi molemmilla puolueopiston kursseilla Suomen yhteiskuntataloudellista kehitystä, maatalous- ja metsäpolitiikkaa sekä tilastooppia. Tilasto-opin valitseminen luennoitavaksi aineeksi osoittaa sen, että puolueen johto koki sen merkityksen suureksi myös puolueen alemmilla tasoilla. Gyllingin panos tässä oli todennäköisesti keskeinen.

Suunnitellessaan luentojaan Gylling joutui huomioimaan kuulijakuntansa luonteen ja oppineisuuden. Puolueopiston kursseille osallistuneet olivat keskimäärin melko nuoria ja lähes kokonaan miehiä. He olivat lähinnä kaupunkien työväestön edustajia. Osallistuneista oli kansakoulun läpäissyt noin kaksi kolmasosaa, kun vastaavasta ikäluokasta yleisesti kansakoulun oli käynyt noin puolet. ${ }^{536}$ Kurssilaiset olivat siis ikäluokkansa keskiarvoa hieman paremmin koulutettuja, mutta Gylling joutui esittämään asiat kansanomaisemmin kuin luennoidessaan yliopistolla.

Vuoden 1913 puolueopisto jäi viimeiseksi ennen sisällissotaa. Tampereen puoluekokouksessa loppuvuonna 1913 opisto herätti ristiriitaisia tunteita ja sen jatkuminen jäi epäselväksi. ${ }^{537}$ Seuraavana vuonna alkanut maailmansota siirsi opistoajatuksen vielä enemmän taustalle.

Gyllingin tekemistä muistiinpanoista on säilynyt ainoastaan Suomen yhteiskuntataloudellinen kehitys -luentosarjaan tehty runko. Hänen pitämistään luennoista se olikin laajin ja merkittävin. Nämä luentomuistiinpanot ovat kiinnostava kokonaisuus, koska niissä esitetään synteesi Suomen taloudellisesta kehityksestä, jossa tietysti maatalouskysymykset olivat tärkeässä osassa. Käsittelen seuraavassa luentoja painottaen tämän tutkimuksen kannalta tärkeitä kysymyksiä. Gyllingin kirjoituksissa oli ainoastaan suppeampia yrityksiä tämän kaltaiseen synteesiin.

Gyllingin luennollaan hahmottelema historiallisen kehityksen malli perustuu selvästi marxilaiseen teoriaan. Gylling on Marxin tavoin historianfilosofisesti materialisti, jonka mukaan historian

536 Ehrnrooth 1992, s.230-235.

537 Ehrnrooth 1992, s. 226-227, 510. 
liikkeellepanevana voimana toimivat ennen kaikkea taloudelliset tekijät. Gylling lähti liikkeelle jaottelemalla yleisluonteisesti taloudellisen kehityksen viiteen pääjaksoon: perhe eli sukukuntatalouteen, feodaalitalouteen, pikkuporvarilliseen kauteen, kauppakapitalismin kauteen ja teollisuuskapitalismin kauteen. Perhetalouden aikana vallitsi kotitarvetuotanto, jossa työnjako oli kehittymätöntä ja tuotantoa johti perheen päämies. Työn tuottavuus oli huono, ja vaihdolla oli vähän merkitystä. Tarve talouden tehostamiseen ja puolustautumiseen ulkoista uhkaa vastaan johti sukukuntien yhtymiseen. Feodaaliherroista tuli johtava luokka, jolloin syntyi maaorjuus. Tuotanto oli edelleen pääasiassa kotitarvetuotantoa, joten vaihdon merkitys pysyi vähäisenä. Feodaalitalous oli vahvimmillaan 1000-1300-luvuilla, jonka jälkeen tavaratuotannon merkitys kasvoi. Tällöin feodaaliherroista kehittyi suurviljelijöitä ja talonpojista työveroa suorittavia alustalaisia. Gylling kutsui tätä feodaalitalouden erikoismuotoa kartanotaloudeksi, mutta ei erotellut sitä omaksi taloudelliseksi pääjaksokseen. ${ }^{538}$

Pikkuporvarilliseen kauteen siirryttiin, kun työnjaon kehittyessä syntyi käsityöluokka, kaupunkilaitos kehittyi ja ammattikuntalaitoksen järjestämänä syntyi pientuotantoa. Vielä tuolloinkaan vaihdon merkitys ei kuitenkaan kasvanut suureksi. Tavaratuotannon merkitys kasvoi uudella ajalla, jolloin vaihtoa välittävän kauppiasluokan valta lisääntyi. Kauppa sai kapitalistisen leiman ja rahan käyttö yleistyi. Näin siirryttiin kauppakapitalismiin. ${ }^{539}$

Gyllingin mukaan taloudellisen kehityksen toistaiseksi viimeinen vaihe oli teollisuuskapitalismi, johon siirryttiin, kun koneellistunut suurtuotanto syrjäytti käsityömäisen pientuotannon. Kapitalismi tunkeutui vähitellen kaikkialle yhteiskuntaan ja synnytti modernin palkkatyöväen. Hän jaotteli teollisuuskapitalismiin kahteen alajaksoon: manufaktuurikauteen ja koneteollisuuden kauteen. ${ }^{540}$

538 TA, Puolueopisto 1910-1913.

539 TA, Puolueopisto 1910-1913.

540 TA, Puolueopisto 1910-1913. 
Karl Kautsky hahmotteli historiallisia ja empiirisiä lakeja kuvaamaan kapitalismin kehitystä ja vei samalla marxilaisuutta yksinkertaistavampaan ja luonnonlakimaisempaan suuntaan. ${ }^{541}$ Gylling nojautui Marxin tulkinnassaan vahvasti Kautskyyn. Tämä tuli hyvin esille muun muassa Marxin Pääoman ensimmäisen osan suomentamisessa. Gylling teki sen suomentamisesta aloitteen Suomalaisen kirjallisuuden edistämisrahaston yhteiskuntataloudellisen osaston ensimmäisessä kokouksessa marraskuussa 1908. Hän taivutteli teosta liian vaikeatajuisena vastustaneet myönteiselle kannalle, joten työ pääsi vuoden kuluttua alkuun kääntäjänään O. W. Louhivuori (1884-1953, vuoteen 1905 Lohtander). Tarkastajaksi löydettiin lopulta T. T. Kaila, joka kävi käännöksen läpi verraten sitä keväällä 1914 ilmestyneeseen Kautskyn kansanomaiseen Volksausgabeen. Gyllingin ehdotuksesta suomenkieliseen laitokseen liitettiin samanlaiset hakemistot kuin Volksausgabessa. Kautskyn tulkinnat olivat siis keskeisellä sijalla käännöstyössä. Pääoman ensimmäisen osan viimeiset vihkot ilmestyivät vasta vuonna 1918 eli kymmenen vuotta työn aloittamisen jälkeen. ${ }^{54}$

Gyllingin tapa määritellä feodalismi tuotantotaloudelliseksi eikä oikeudelliseksi järjestelmäksi osoittaa myös tarkastelukulman marxilaisuuden. ${ }^{543}$ Gyllingin jaottelu on huomattavasti uudempi kuin Marxin, mikä selittää sen, että hän jaotteli kapitalismin tarkemmin eri ajanjaksoihin. Gyllingin luentomuistiinpanoissa ei suoraan mainita sitä, että teollisuuskapitalismin korvautuminen sosialistisella järjestelmällä on odotettavissa. Gylling tuskin epäili tätä, mutta ei missään käsitellyt tarkemmin tulevaa sosialismia.

\section{Gronow 1986, s.13-14.}

542 Heikkinen ja Mauranen 1981, s.54-55; Ehrnrooth 1991, s.112-113. Myöhemmin Karjalan johtajana Gylling arvosteli käännöstä siitä, että se perustuu liikaa Kautskyn omavaltaiseen kansantajuistuttamiseen, muttei maininnut omaa osuuttaan siinä.

543 Historiantutkimuksessa voidaan karkeasti erottaa kaksi tapaa ymmärtää feodalismi: suppea määritelmä, jolla tarkoitetaan erityisesti läänityslaitosta ja marxilaisten käyttämä laajempi määritelmä, joka keskittyy kartanotaloudelliseen tuotantotapaan. Hietaniemi, Tapani, Missä diskurssissa nykyiset feodalismikeskustelut liikkuvat? Teoksessa Feodalismi. Toim. Hietaniemi, Tapani et al. Tampere 1997, s.13-15. 
Gylling ei käsittänyt kehitysmallia dogmaattisen sitovaksi, sillä hän totesi seuraavasti: "Suomen taloudellisessa kehityksessä esiintyvät yleisistä taloudellisista kehitysjaksoista eräät varsin heikosti". Tämä tarkoitti lähinnä feodalismia, jota ei ainakaan tyypillisessä muodossaan ollut esiintynyt Suomessa. ${ }^{54}$ Lisäksi suomalainen yhteiskunta oli siirtynyt vasta puolittain teollisuuskapitalismin kauteen. Gylling erotteli Suomen taloudellisessa kehityksessä kaksi pääjaksoa: esikapitalistisen ajan (noin vuoteen 1850) ja kapitalistisen ajan (noin vuodesta 1850 eteenpäin). Hän jakoi esikapitalistisen ajan varhaisempaan jaksoon (noin vuoteen 1750) ja myöhempään jaksoon (noin 1750 - noin 1850). ${ }^{545}$

Gylling korosti sitä, että rälssiaatelin omaisuus pysyi Suomessa keskiajalla vähäisenä. Aatelivalta rasitti rahvasta, muttei vakiintunut perinnölliseksi feodaalisuhteeksi. Unionikaudella kehitys kohti feodalismia voimistui, mutta "talonpoikien kapina" esti lopullisen siirtymisen siihen. ${ }^{546}$ Gylling katsoi, että talonpoikien oma taistelu esti heidän vajoamisensa maaorjuuteen. Rahvas ei siis ollut historian kulussa tahdotonta massaa, vaan se osallistui aktiivisesti olosuhteiden muokkaamiseen. Käsityksessä näkyy vahva usko luokkataistelun oikeutukseen ja merkitykseen. Samalla se osoittaa, ettei Gyllingin historiankäsitys ollut suoraviivaisen fatalistista, mikä on usein katsottu tyypilliseksi kautskylaisuudelle. ${ }^{547}$

544 Tätä mieltä ollaan myös nykyisin, sillä useimpien tutkijoiden mielestä keskiaikaisesta feodalismia ei Suomessa esiintynyt sen enempää taloudellisessa kuin oikeudellisessakaan mielessä. Kustaa Vaasan aikana feodaaliset rakenteet voimistuivat valtakunnassa selvästi, mutta silloinkaan ei ollut kyse varsinaisesta feodalismista. Jouko Nurmiainen ja Mikko Piippo esittävät suomalaisesta feodalismista katsauksen ja päätyvät siihen tulokseen, että käsitteen käyttö Suomen historiassa on erittäin ongelmallista. Ks. tarkemmin Nurmiainen, Jouko - Piippo, Mikko, Suomalainen historiankirjoitus ja feodalismi. Teoksessa Feodalismi. Toim. Hietaniemi, Tapani et al., Tampere 1997, s.309-328.

545 TA, Puolueopisto 1910-1913; vrt. Heikkinen - Mauranen 1983 A, s.14-15.

546 TA, Puolueopisto 1910-1913.

547 Kautskyn fatalismia on kuitenkin ilmeisesti liioiteltu. Ks. Gronow 1986, s.45. 
Gylling mukaan historian tärkeimmät voimat olivat taloudelliset tekijät, jotka olivat uskonpuhdistuksenkin taustalla. Kuningas anasti uskonpuhdistuksen avulla kirkon omaisuuden ja synnytti modernin virkamieshallinnon. 1500- ja 1600-luvuilla sodat ja valtion rahantarve kasvattivat suuraatelin maaomaisuutta ja valtiollista valtaa. Kuninkaasta tuli aatelin tahdon toimeenpanija, mikä johti talonpoikien aseman heikkenemiseen. Gylling katsoi, että vain talonpoikaiskuninkaaksi kutsuttu Kaarle IX piti jonkin verran kansan puolta. Suomen aatelisto oli hyödyttänyt vähäisessä mittakaavassa yhteiskuntaa järjestäessään hallintoa, perustaessaan kaupunkeja ja parantaessaan kulkuneuvoja. Useimmat olivat kuitenkin vain "hyödyttömiä riistäjiä., ${ }^{48}$

Gylling katsoi, että nuijasota oli "ponteva yritys päästä aatelin ikeestä". Se alkoi Pohjanmaalta taisteluna sotilaiden mielivaltaa vastaan mutta kehittyi levitessään aatelisvastaiseksi kapinaksi, mikä "hukutettiin verivirtoihin". Vähitellen tyytymättömyys aatelivaltaan levisi myös porvariston ja papiston piiriin. Tuloksena oli iso reduktio, jonka tuloksena aatelin maaomistus väheni, mutta etuoikeudet pysyivät ennallaan. ${ }^{549}$

Gylling oli selvästi talonpoikien puolella, mikä yhdisti hänet vanhaan fennomaanisen historiantutkimuksen traditioon. Sen johtava edustaja Yrjö Koskinen nimittäin asettui nuijasodasta kirjoittaessaan varauksetta suomenkielisten talonpoikien puolelle "ruotsinkielisiä riistäjiä" vastaan. Koskisen mielestä kapinan johtaja Jaakko Ilkka oli talonpoikainen sankarihahmo. ${ }^{550}$ Gyllingin

548 TA, Puolueopisto 1910-1913.

549 TA, Puolueopisto 1910-1913.

550 Koskisen tulkinnasta tarkemmin Yrjö-Koskinen, Yrjö Sakari, Nuijasota. Sen syyt ja tapaukset. 2. uudistettu painos. Helsinki 1877. Nuijasota on ollut eräs keskeisimmistä Suomen historiantutkimuksen kiistakysymyksistä ja mainio esimerkki historiantutkimuksen aikasidonnaisuudesta. Pentti Renvall esitti nuijasodasta 1940-luvulla uuden tulkinnan, missä hän katsoi kapinan syyksi sotaväsymyksen, talonpoikien henkisen kehittymättömyyden ja kruunua tavoitelleen Kaarle-herttuan kiihotuksen. Renvallin sankari oli Suomen kokonaisetua ajanut Klaus Fleming, kun taas Jaakko Ilkka esitettiin vain oman edun tavoittelijana. Ks. esim. Renvall, Pentti, Kuninkaanmiehiä ja kapinoitsijoita Vaasa-kauden Suomessa. II painos. Helsinki 1962, s.142-159, 176- 
puolenvalinnan aatteellisena taustana ei kuitenkaan ollut kielikysymys vaan marxilainen luokkataisteluoppi.

Gyllingin mukaan Länsi-Euroopassa kehittyi 1600-luvulla kartanotalous, joka vilkastutti teollisuutta ja kauppaa. Kehitys levisi syrjäisempiinkin maihin kuten Suomeen. Viljanvienti lisääntyi, jolloin aateliset tuotantoa tehostaakseen muuttivat tilansa suurtiloiksi. Talolliset joutuivat monissa maissa maaorjiksi. Suomessakin osa aatelitiloista muuttui suurtiloiksi, mikä aiheutti lampuotiluokan kehittymisen ja käsitteen "torppari" muuttumisen (ennen oli ollut uudisviljelijä kylän mailla). Suomessa alustalaisista ei tullut varsinaisia maaorjia, mutta samaan suuntaan vaikuttivat seuraavat tekijät: väestön liikuntavapauden supistaminen, rajoitukset torppari- ja uudistilojen perustamiseen talonpoikaistaloissa, pakkopalveluslainsäädäntö sekä aatelin oikeus kotikurinpitoon alustalaisiinsa nähden. ${ }^{551}$ Vaikka Gyllingin mukaan feodalismia ei varsinaisesti Suomessa kehittynytkään, sen suuntaisia ilmiöitä oli kuitenkin tällläkin.

Gylling katsoi, että 1700-luvun puolivälissä maatalousoloissa tapahtui voimakas muutos. Taloudellinen kehitys voimistui johtuen seuraavasta neljästä seikasta: 1. pitkä rauhanaika, 2. vaihdon kehitys, minkä taustalla oli kulkuneuvojen parantuminen, uusien kaupunkien perustaminen ja kauppavapauden laajentuminen, 3. viljanhinnan nousu ja viennin kasvu sekä 4. metsätuotteiden viennin kasvu. Suomessa alettiin edistää maataloustekniikkaa ja suosia uudisasutusta väestön lisäämiseksi. 1700-luvun loppupuolella väestö lisääntyi nopeasti, maan yksityisomistus vakiintui ja

192. Heikki Ylikangas arvosteli 1970-luvulla tätä näkemystä ja palasi osittain Koskisen linjoille. Ylikankaan mielestä kapinan syy oli viime kädessä suurissa yhteiskunnallisissa epäkohdissa ja ristiriidoissa. Ylikangas, Heikki, Nuijasota. Keuruu 1977, s. 302-319. Viimeisin lenkki tulkintojen ketjussa on Paavo Haavikon piirtämä kuva nuijasodasta tietoisena kapinana yhtäältä aatelia ja toisaalta keskusvaltaa vastaan. Haavikko, Paavo, Nuijasota, sisällissodan vuodet 1596-1599. Juva 1996, s.194-197; Nuijasodan eri tulkintojen taustoista tarkemmin Ahtiainen, Pekka - Tervonen, Jukka, Menneisyyden tutkijat ja metodien vartijat. Matka suomalaiseen historiankirjoitukseen. Helsinki 1996, s.139-142.

551 TA, Puolueopisto 1910-1913. 
maaseudun yhteiskuntarakenne muuttui. Ennen 1700-luvun puoliväliä maaseudulla ei ollut paljoakaan talonpoikia alempaa väestöä mutta sen jälkeen maanvuokraajien ja maatyöläisten määrä alkoi kasvaa nopeasti. Kaikki nämä tekijät mullistivat maaseudun olot 1700-luvun loppupuolella. ${ }^{552}$

Kapitalismin kehittyessä teollisuus - erityisesti puutavarateollisuus - otti vähitellen maataloudelta johtavan aseman. Lainsäädännössä tehtiin porvarillisia uudistuksia, joilla talous liberalisoitiin. Metsäkapitalismin kehittyminen huononsi toimeentulomahdollisuuksia maaseudulla. Metsän hinnan nousu ja talonpoikien rahantarpeen lisääntyminen johtivat torpparien ja mäkitupalaisten metsännautintaoikeuksien supistamiseen. Nämä tekijät saivat aikaan sisäistä muuttoliikettä ja siirtolaisuutta. Gylling totesi lopuksi, että kapitalismin edelleen kehittyessä tekniikan edistyminen ja voimistuvat suhdannevaihtelut tulevat aiheuttamaan välillä suurta työttömyyttä. ${ }^{553}$

Gyllingin mukaan kapitalistinen kehitys oli ollut Suomessa suhteellisen voimakasta ja nopeaa. Tässä kehityksessä keskeistä oli jatkuva muutos. Hän ei luennoissaan suoranaisesti arvioinut suomalaisen kapitalismin kehitysastetta, mutta ilmeisesti katsoi, että kapitalistinen kehitys oli agraarisessa Suomessa vielä selvästi kesken. ${ }^{554}$

Pekka Korpisen mukaan Gyllingin tutkimuksia ei voida varsinaisesti laskea marxilaiseksi yhteiskunta-analyysiksi, vaan ne ovat ennemminkin sosiaalipoliittista kansallista tutkimusta. ${ }^{555}$ Sakari Heikkinen ja Tapani Mauranen ovat kuvanneet Gyllingin lähestymistapaa kolmella määreellä: historiallinen, empiirinen ja

552 TA, Puolueopisto 1910-1913.

553 TA, puolueopisto 1910-1913.

554 Vrt. Ehrnrooth 1992, s.263-265. Gyllingin näkemykset eivät tässä kohdin ole välttämättä ristiriitaisia, kuten Ehrnrooth katsoo. On mahdollista, että Gylling katsoi kapitalistisen kehityksen olleen Suomessa varsin nopeaa, mutta sen olevan kuitenkin vielä kesken ja jäljessä kehittyneimmistä kapitalistisista maista.

555 Korpinen, Pekka, Edvard Gylling - sosialisti ja tiedemies. Työväen taloudellisen tutkimuslaitoksen katsaus 4/1981, s.47. 
tilastollinen. Sen sijaan heidänkin mielestään Gyllingin luokittelu marxilaiseksi on ongelmallista, koska hän ei juuri käyttänyt teorioita, jonka lisäksi hänen käyttämänsä marxilainen käsitteistö oli luonteeltaan varsin yleisluonteista ja sen yhteys itse analyysiin löyhä. Gyllingin marxilaisuus näkyy lähinnä kysymyksenasetteluissa ja käytännön yhteiskuntakritiikissä, jossa on vaikutteita myös historialliselta kansantaloustieteeltä. ${ }^{556}$

Jari Ehrnrooth tarkentaa oivaltavasti Gyllingin marxilaisuuden luonnetta toteamalla, että hänen talouskriittinen teoreettinen marxilaisuutensa oli vähäistä, mutta yhteiskuntamuotojen universaaleja kehitysvaiheita koskeva historianfilosofinen marxilaisuutensa keskeistä. Vaikka Gylling oli kansantaloustieteilijä, hänen historiallinen suuntautumisensa oli niin vahva, että häntä houkutti enemmän yhteiskuntamuotojen kehitysmalli kuin talouskritiikki. Gyllingiä kiinnosti yhteiskuntakehityksen konkreettinen erittely ja sen yleistäminen marxilaisella, pääasiassa Kautskyltä omaksutulla käsitteistöllä. ${ }^{557}$

Voidaan sanoa, että Gylling oli historiallinen, tilastollinen ja empiirinen tutkija eikä marxilainen talous- ja yhteiskuntateoreetikko samalla tavoin kuin esimerkiksi Kuusinen. Hänen luennoidessaan Suomen yhteiskuntataloudellisesta kehityksestä tarkastelukulma on kiistatta marxilainen, mutta varsinaisen teoreettinen aines on vähäinen. Sen sijaan Gyllingin historianfilosofiset käsitykset ovat varsin marxilaisia tai oikeastaan kautskylaisia, joskaan hän ei tulkinnut historian kulkua kovin dogmaattisesti.

Kautskylaisen näkemyksen mukaan sosialistinen vallankumous oli mahdollinen vasta kapitalismin viimeisessä vaiheessa. Kuusinen antoi luennollaan varsin ulkopuolisen kuvan sosialismista

556 Heikkinen - Mauranen 1983 A, s.19-20.

557 Ehrnrooth 1992, s.257-260. Jari Ehrnroothin mukaan Gyllingin luennot yhteiskuntataloudellisesta kehityksestä olivat vallankumousproblematiikan kannalta keskeisiä, koska ne välittivät kuvan suomalaisen yhteiskunnan kehitysasteesta. Kuusinen puolestaan antoi luennoillaan talousopista kuvan sosialistisen vallankumouksen edellytyksistä. Gyllingin antaman historiallisen kuvan ja Kuusisen teoreettisen mallin lomittuessa päällekkäin oppilaille muodostui kuva Suomen vallankumouksellisesta kypsyysasteesta. 
ja siihen johtavasta vallankumouksesta. Finanssikapitalismin kehitys muokkasi kaiken valmiiksi, joten työväenliikkeen tehtäväksi jäi vain joukkojen organisoiminen ja tietopuolinen valmistaminen sekä kehityksen seuraaminen vallankumouksen osuvaa ajoittamista silmälläpitäen. Vallankumouksellisen tilanteen edellytyksenä oli se, että tuotannon omistus oli keskittynyt harvalukuiselle finanssikapitalistien ryhmälle, joka esiintyi koko muun kansan omistamattomuuden vastakohtana. Sosialismiin siirtyminen oli siis odotettavissa ensin siellä, missä kapitalismi oli kehittynyt pisimmälle. ${ }^{558}$

Gyllingin luentojen antama kuva suomalaisesta yhteiskunnasta poikkesi selvästi Kuusisen esittämän vallankumouksellisen tilanteen kanssa. Finanssikapitalismin voimakkaasta keskittymisestä sekä kapitalistien ja proletariaatin kärjistyneistä suhteista johtuva vallankumouksellinen tilanne ei ollut täällä vielä lähellä. Maatalouden ongelmat olivat vielä tässä vaiheessa huomattavasti keskeisempiä kuin teollisuuden tilanne. Gyllingistä ja ilmeisesti kaikista johtavista suomalaisista sosialidemokraateista sosialismin täytyi näyttää kaukaiselta utopialta, joka ei ainakaan täällä voi toteutua vielä vuosikymmeniin.

\section{Tutkimustyö yhteiskunnallisen näkemyksen syventäjänä}

Politiikka vei entistä enemmän Gyllingin aikaa ja voimia mutta hän jatkoi myös tieteellistä toimintaansa. Alkuvuodesta 1910 Gylling haki Helsingin yliopistosta kansantaloustieteen ja tilastotieteen dosentin paikkaa. Historiallis-kielitieteellinen osasto pyysi maaliskuussa kansantaloustieteen professorilta J. H. Vennolalta

558 Ehrnrooth 1992, s.245-250; Kurssilaisten suhtautumisesta opetuksen on säilynyt muistelmia. Niiden mukaan Kuusisen luennot olivat useimmille liian teoreettisia. Sen sijaan Gyllingin luennot Suomen talouselämän kehityksestä koettiin varsin kiinnostaviksi. Ks. KA, AYK, kansio 2, muistiinpanot Seija Mannisen Erkki Vuorelle tekemästä haastattelusta ja Louhikko, E. K., Teimme vallankumousta. Helsinki 1943, s.83-84. 
(1872-1938) lausuntoa asiasta. Hän antoi lausuntonsa historialliskielitieteellisen osaston kokouksessa 7.5.1910.559

Vennola totesi, että hakijan pääteos oli väitöskirja, joka vastasi lisensiaattityötä hyvin. Aiheen käsittely oli kuitenkin enemmän historiallinen kuin kansantaloustieteellinen. Tilastotieteellisesti tutkimus oli arvokas ja valaisi ensimmäisen kerran tärkeää taloudellista ilmiötä ja maalaisväestön sosiaalisten suhteiden kehitystä. ${ }^{560}$

Lausunnossaan Vennola huomautti, että hakijan muut julkaisut olivat tilastollisia. Invalidivakuuskomitean teettämä tutkimus koski vain viittä kuntaa, joka oli ehkä liian vähän. Toisaalta hakijan ansio sen tekemisessä oli suuri, käsittely oli asiantuntevaa ja toi uutta tietoa esiin. Alun perin pro graduna ilmestynyt tutkimus maanviljelystyöväestä Ikaalisissa olisi kaivannut viimeistelyä ennen julkaisemista, mutta osoitti kuitenkin itsenäistä huomiokykyä. Arvokas lisä tuotantoon olivat Suomen Kartaston kartografiat ja pienemmät kirjoitukset. Vennola totesi kuitenkin, että Gylling oli tuotantonsa perusteella ahkera ja monipuolinen tutkija, joka antoi muodollisissa tekijöissä aihetta muistutuksille, mutta pyrki syventymään asiaan, omasi arvostelukykyä ja kyvyn vetää johtopäätöksiä käsiteltyään aineistoaan itsenäisesti ja tieteellisesti. Lisäksi hän oli julkaissut tieteellisesti arvokkaita kirjoituksia. Hakijalla oli tutkimustyön lisäksi myös opetuksellisia ansioita, sillä hän oli auskultoinut suomalaisessa normaalilyseossa ja opettanut vuoden liikemiesten kauppaopistossa. Vennolan mielestä Gylling voitiin hyväksyä dosentiksi, joskin pelkästään tilastotieteen alalla, koska hänen tuotannossaan oli varsin vähän kansantaloustiedettä. ${ }^{561}$

Historiallis-kielitieteellinen osasto jätti asian pöydälle seuraavaan kokoukseen, joka pidettiin 14.5.1910. Roomalaisen kirjalli-

559 HYKA, Keisarillisen Aleksanterin kanslerin viraston yliopiston vihko n:o 8 vuodelta 1910, asia n:o 481.

560 HYKA, Keisarillisen Aleksanterin kanslerin viraston yliopiston vihko n:o 8 vuodelta 1910, asia n:o 481.

561 HYKA, Keisarillisen Aleksanterin kanslerin viraston yliopiston vihko n:o 8 vuodelta 1910, asia n:o 481. 
suuden professori F. V. Gustafsson (1853-1920) vastusti dosenttihakemuksen hyväksymistä, koska hänen mielestään hakija oli tehnyt tilastollista tutkimusta ja tuonut esiin uusia tietoja, mutta ei ollut osoittanut riittävää itsenäistä tutkimusotetta. Suomen siviilioikeuden professori J. W. Chydenius (1863-1926), käytännöllisen teologian professori K. A. Appelberg (1851-1925) sekä maatalouskemian ja -fysiikan professori Arthur Rindell (1852-1936) yhtyivät tähän kantaan, joskin kaksi viimeksi mainittua suuresti epäillen. Soveltavan fysiikan professori Th. Homén (1858-1923) pyysi miettimisaikaa. Historiallis-kielitieteellinen osasto ehdotti kuitenkin Vennolan lausuntoon vedoten, että Gylling nimitettäisiin tilastotieteen dosentiksi, mutta vielä vaadittiin konsistorin hyväksyntä. Nimitystä käsiteltiin konsistorin kokouksessa 6.6.1910. Homén oli tullut kielteiseen tulokseen seuraavalla perusteella: hakijan julkaisut olivat enemmän aineiston ja numeroiden yhdistelyä kuin joidenkin kysymysten tilastotieteellistä käsittelyä. Dogmatiikan ja moraalin professori C. G. A. Rosenqvist (1855-1917) sekä fysiologisen kemian ja farmalogian professori E. E. Sundvik (1849-1918) puolsivat suuresti epäillen nimitystä, koska osasto oli kannattanut sitä melkein yksimielisesti. Pedagogiikan ja dialektiikan professori Waldemar Ruin (1857-1938) kannatti yksiselitteisesti nimitystä. Suomen ja skandinavian historian professori E. G. Palmén korosti, että hakijan tutkimuksilla oli merkittävää tilastotieteellistä arvoa, joten hän oli pätevä dosentiksi. Palmén totesi, että vedotessaan huolimattomuuteen vastustajat korostavat asiaa, joka ei ennenkään ole ollut tärkeää dosentiksi nimitettäessä. Yliopiston rehtori ja kreikkalaisen kirjallisuuden professori I. A. Heikel (1861-1952) kannatti nimitystä, mutta Gustafsson pysyi kielteisessä kannassaan. Konsistori esitti kanslerinvirastolle äänin 8-2 Gyllingin nimittämistä tilastotieteen dosentiksi. ${ }^{562}$

Gyllingin nimittämistä dosentiksi vastustivat professoreista Homén ja Gustafsson. Kyseessä saattoivat olla tieteellisten teki-

562 HYKA, Keisarillisen Aleksanterin kanslerin viraston yliopiston vihko n:o 8 vuodelta 1910, asia n:o 481. 
jöiden lisäksi myös poliittiset motiivit. ${ }^{563}$ Muut professorit kuitenkin hyväksyivät nimityksen, vaikkei kukaan heistä ollut sosialidemokraatti. Kielitaistelulla tuskin oli tässä tapauksessa suurta merkitystä, koska Gylling ei ollut kummankaan osapuolen kannalta erityisen vastustettava henkilö. Hän oli ruotsinkielisen kodin kasvatti, joka puhui ja kirjoitti yleensä suomenkielellä. Poliittisesti kielikysymys oli hänelle - kuten yleisemminkin sosialidemokraateille - sivuseikka.

Gylling hyväksyttiin siis tilastotieteen dosentiksi, mitä ainetta hän opetti yliopistossa vuodesta 1910 lähtien. Erkki Salomaan mukaan Gyllingille tarjottiin myöhemmin professuuria, mikäli hän jättäisi työväenliikkeen. ${ }^{564}$ Väitteen uskottavuutta heikentää se, ettei Gylling tehnyt yhtän laajaa tutkimusta väitöskirjansa jälkeen, joten hänellä oli siis varsin vähän tieteellistä näyttöä. Henkilökohtainen ylimääräinen professuuri olisi kuitenkin saattanut olla mahdollinen. Gebhard oli nimitetty maanviljelyksen kansantalouden ja tilastotieteen ylimääräiseksi professoriksi vuonna 1909. Hän ei kuitenkaan monilta julkisilta tehtäviltään ehtinyt hoitamaan tehtävää kovinkaan paljoa, joten alan lisäopetukselle saattoi olla tarvetta. ${ }^{565}$

Gyllingin tutkimusaiheet monipuolistuivat dosentuurin saamisen jälkeen. Hän ei keskittynyt enää niin vahvasti maanvuokraajien ja tilattoman väestön ongelmiin, joskin nekin pysyivät hänen tutkimuskohteinaan. Entistä tärkeämmiksi aiheiksi nousivat kuitenkin erityisesti väestökysymykset, joilla oli vahva yhteys maatalouden kehitykseen ja siellä syntyneeseen yhteiskuntarakenteeseen. Käsittelen seuraavassa Gyllingin keskeisiä kirjoituksia tästä teemasta.

Gylling valitti jo vuonna 1909 sitä, että Suomen virallinen tilasto ei ollut kehuttavalla kannalla. Tämä koski erityisesti sen

563 Nygård, Toivo, Suomalainen äärioikeisto maailmansotien välillä. Ideologiset juuret, järjestöllinen perusta ja toimintamuodot. Studia Historica Jyväskyläensia 25. Jyväskylä 1982, s.46.

564 Salomaa väittää, että Fanny Achrén olisi sanonut näin. Salomaa 1967, s.165166.

565 Alanen 1964, s.242-243. 
tärkeintä haaraa eli väestötilastoa, josta ei saanut selville luotettavasti edes väkilukua. Puutteista huolimatta väestötilastomme on kuitenkin aarreaitta, koska se ulottuu yhdessä Ruotsin tilaston kanssa kauemmaksi kuin minkään muun maan. Sen avulla voidaan seurata väkiluvun kehityksen lisäksi muun muassa syntyväisyyttä ja ikä-, siviilisääty- ja ammattiryhmitystä. Suomen väestöhistoriallinen aineisto oli tilastolliselta, taloustieteelliseltä ja historialliselta kannalta erittäin arvokas. Kuitenkin sitä oli tutkittu varsin vähän. Ainakin osittaisena syynä tähän oli se, että aineisto oli varsin hajanaisesti sijoitettu ja huonosti järjestetty. Gylling halusi Tilastollisen Päätoimiston kokoavan ja järjestävän sen uudelleen tai "maamme taloudellinen kehitys... tulee jatkuvasti jäämään entiseen hämäräänsä”. ${ }^{566}$ Gylling siis piti väestökysymyksiä varsin tärkeinä yhteiskunnallisen kehityksen ymmärtämisen kannalta ja valitteli niiden puutteellista tutkimista. Tämän valossa on ymmärrettävää, että hän alkoi kirjoittaa niistä enemmän.

Gylling oli väestötutkijana lähellä O. K. Kilpeä (1878-1937), joka oli myös Gebhardin oppilas. Kilpi oli Gyllingin tavoin saanut vaikutteita muun muassa Marxilta, Schmollerilta ja Sombartilta. Kumpikin tutki väestöilmiöiden yhteiskunnallisia taustoja, muttei pyrkinyt kehittämään välineitä, joilla voisi vaikuttaa epäsuotuisaan väestökehitykseen. Molemmat tekivät tilastollista tutkimusta, joka lisäsi ymmärrystä ihmisen sosiaalisesta ja taloudellisesta käyttäytymisestä. He etsivät väestöilmiöiden taustaa sosiaalisista oloista ja eri tuotantomuotojen - erityisesti kapitalismin - kehityksestä. Tässä tulivat esille historiallisen kansantaloustieteen nuoremman siiven vaikutus. ${ }^{567}$

Gylling tarkasteli yhteiskunnallisten ja taloudellisten olojen heijastumista väestökehityksessä. Pohjana oli jako esikapitalistiseen maatalousvaiheeseen ja kapitalistiseen aikaan. Ensimmäisessä vaiheessa väestön elinmahdollisuudet ja väestönkasvu perustuivat maatalouteen ja uudisraivaukseen. Tästä syystä väestönkasvu oli ollut nopeampaa niillä alueilla, joilla maatalous oli voinut vielä

566 Gylling, Edvard, Hiukan vanhemmasta väestötilastostamme. YhtA 2/1909 (D), s.88-92.

567 Pitkänen 1988, s.104-105, 166; Allardt 1997, s.83. 
laajentua. 1800-luvun jälkipuoliskolla taloudellinen kehitys ja väestönkasvu alkoivat siirtyä teollistumiskehityksen puitteisiin. Luonnollisen väestönkasvun pääosa tapahtui edelleen samoilla alueilla kuin aikaisemmin, mutta voimistunut siirtolaisuus alueelta toiselle muutti kuvaa. ${ }^{568}$

Gylling luotasi Suomen väestökehitystä aina 1500-luvulta asti. Gyllingin mukaan 1500-luvulla Suomen väkiluku - mukaan lukien "vanha Suomi" - oli jonkin verran yli 300000 ihmistä. 1600-luvun loppuun tultaessa se oli noussut noin puoleen miljoonaan henkeen. Ison vihan päätyttyä Suomessa oli väkiluku sotien ja nälkävuosien harventamana laskenut jälleen reiluun 300000 henkeen. Tämän jälkeen alkoi nopea väestönkasvu. 1700-luvun puolivälissä Suomessa asui noin 530000 henkeä. 1700-luvun loppupuolella väestö kaksinkertaistui.1700-luvun puolivälissä kaupunkien väestö oli alle viisi prosenttia maan koko väkiluvusta, joten maaseutu oli väestöolojen kannalta erittäin keskeinen. Se oli luonteeltaan vielä varsin yhtenäinen, koska torpparit ja tilaton väestö olivat vasta syntymässä. 1700-luvun puolivälistä alkaen väestö kasvoi nopeimmin alueilla, joissa uudisraivauksella oli hyvät mahdollisuudet. Maanvuokraajien ja tilattomien luokat alkoivat samoihin aikoihin kehittyä. 1800-luvun alun olot muistuttivat vielä melko paljon 1700-luvun puolivälin tilannetta. Kaupunkiväestön osuus oli varsin pieni, väestön leviäminen maan eri osiin oli erittäin epätasaista sekä ero vanhojen asutuskeskusten ja entisten erämaaseutujen välillä oli selvä. ${ }^{569}$

1800-luvun kuluessa talollisväestön lisääntyminen heikkeni. Väestönlisäys kohdistui yhä suuremmassa määrin torppareihin, mäkitupalaisiin ja maalaistyöläisiin. Näin runsas sata vuotta mullisti olosuhteet Suomen maaseudulla. Gylling katsoi tämän kehityskulun saavuttaneen huippunsa noin vuonna 1865 , jolloin oli syntynyt merkittävä maanvuokraajaluokka, joka oli laajoissa

568 Pitkänen 1988, s.143-144; Alapuro - Alestalo 1992, s.92-94.

569 Gylling, Edvard, Väestö. Sata vuotta Suomen sivistyselämää. Kansanvalistusseuran Toimituksia 158. Helsinki 1911 (B), s. 31-33. 
osissa maata maaseutuväestön lukuisin kerros. Näin maaseudun vanha talonpoikainen leima oli hävinnyt. ${ }^{570}$

Vuosien 1865-1868 katovuosien jälkeen alkoi uusi suunta kehityksessä, kun väestönkasvu kohdistui yhä selvemmin kaupunkeihin ja maaseudun teollisuusseutuihin. 1890-luvulla koko maan väestölisäyksestä tuli jo kolmannes kaupunkeihin. Vuonna 1909 kaupunkiväestön osuus oli jo noin $15 \%$ koko maan väestöstä. Väestönkasvu kokonaisuudessaan oli edelleen voimakasta. 1800-luvun lopun merkittävimpiä muutoksia oli muuttoliikkeen nopea kasvu. Muissakin maissa havaittua pakoa maaseudulta esiintyi 1900-luvun alun Suomessakin. Siirtolaisuus oli sekin lähinnä maanviljelysalueilta lähtevä muuttoliike. Tapahtunut väestönkehitys tasoitti alueellisia asutusoloja merkittävästi. ${ }^{571}$

Gylling kirjoitti, että syntyneisyys vähentyi koko 1800-luvun kun taas kuolleisuus oli vielä 1860-luvulla yhtä suurta kuin vuosisadan alussa. Tämän jälkeen kuolleisuus vähentyi syntyvyyttä nopeammin, mikä aiheutti nopeaa väestönkasvua ja keski-iän nousua. Tärkeä piirre oli myös kaupunkien nopea väestönkasvu. Gyllingin katsoi, että Suomen kaupungit olivat aikaisemmin "oikeita väestön hautoja". Kuolleisuus ja syntyneisyys olivat tasoissa, joten kaupunkien kasvu perustui muuttoon maaseudulta. 1800-luvun loppupuolella kaupunkiväestön luonnollinen lisääntyminen kasvoi tuntuvasti. ${ }^{572}$

Gylling korosti sitä, että edellisen sadan vuoden aikana Suomen väestöolot olivat muuttuneet erittäin merkittävästi. Väkiluku oli lähes kolme kertaa suurempi, sen sisäinen rakenne oli täysin muuttunut ja väestökehityksen painopiste oli siirtynyt maanviljelysalueilta kaupunkeihin ja maaseudun teollisuuskeskuksiin. Vuodesta 1749 vuoteen 1908 väkiluku oli kasvanut reilusta puolesta miljoonasta yli kolmeen miljoonaan eli noin kuusinkertaiseksi,

570 Gylling 1911 B, s.34; vrt. Gylling, Edvard, Väentiheys v.1749 ja väenlisäys vuosina 1749-1908. Suomen Kartasto 24-28, VI. Helsinki 1911 (C), s.36.

571 Gylling 1911 B, s.34-35.

572 Gylling 1911 B, s.37; Kari Pitkäsen mukaan väite että kaupungit olivat ennen varsinaisia "väestön hautoja", on Suomen osalta melkoisesti liioiteltu. Pitkänen 1988, s.145. 
minkä taustalla oli taloudellisten ja yhteiskunnallisten olojen raju muutos. ${ }^{573}$

Gylling katsoi, että väkiluvun kehityksessä kuvastuivat yhteiskunnallisen kehityksen eri puolet. Voimakas taloudellinen kehitys tarvitsi työvoimaa ja nopeutti näin väestönkasvua. Tämä selitti myös Euroopan siirtolaisuuden Yhdysvaltoihin, missä väestönkasvu ei pysynyt taloudellisen kehityksen perässä. 1800-luvun lopulla kehityksen suunta muuttui jyrkästi kun maanviljelyksen ja uudisraivauksen merkitys väestönkasvun perustana menetti merkitystään. Torpparien lukumäärän kasvu alkoi pysähtyä mutta metsätöiden lisääntyneen työtarpeen takia maaseudun tilaton väestö kasvoi edelleen. 1800-luvun lopun merkittävin taloudellinen ilmiö Suomessa oli teollisuuden, liikenteen ja kaupunkien voimakas kehitys. Kun maanviljelys menetti johtavan taloudellisen asemansa, sen merkitys myös väestönkehitykseen väheni. Gylling totesi, että "tällä tavoin johtaa taloudellisen tuotannon suunta väestönkehitystä perässään". ${ }^{574}$

Gyllingin näkemys noudatti seuraavaa ajatuskulkua: taloudellinen kehitys määräsi yhteiskunnallista muutosta, mikä vaikutti väestökehitykseen keskeisesti. Suomen 1800-luvun väestökehityksen taustalla oli kapitalistisen vaihdantatalouden leviäminen. Tämä ajattelu sopi hyvin marxilaisen teorian piiriin, vaikkakin taloudellista materialismia korostivat myös monet muutkin kuin marxilaiset tutkijat. Gylling totesi ison vihan jälkeisestä ajasta seuraavasti: "Tällöin saa nimittäin alkunsa se väestökehitys, joka vähälukuisesta ja heikosta Suomen väestöstä oli kasvattava kansakunnan, joka v.1809 kykeni aloittamaan oman valtiollisen elämän". 575

Väestökehitys oli siis tärkeä taustatekijä valtiolliselle kehitykselle. Kun taas väestökehitys oli riippuvainen yhteiskunnallisesta muutoksesta ja erityisesti talouden kehityksestä, taloudelliset tekijät olivat viime kädessä historian keskeiset voimat.

573 Gylling 1911 B, s.37; vrt. Gylling 1911 C, s.38.

574 Gylling, Edvard, Katsaus Suomen väkilukuun 1749-1908. Työväen Kalenteri IV/1911, 1910 (A), s.126-134.

575 Gylling 1911 B, s. 31. 
Gylling oli sidoksissa aikakaudella vallinneeseen väestöajatteluun. Hän painotti taloudellisia tekijöitä, mutta ei muuttoliikettä lukuun ottamatta pohtinut väestöllisten prosessien yhteyttä taloudelliseen ja yhteiskunnalliseen muutokseen. Gylling kirjoitti talouden vaikutuksesta syntyvyyteen ja kuolleisuuteen varsin yleisellä tasolla, eikä yksilöinyt väitteitään. Kari Pitkäsen mukaan on kyseenalaista, tiedostiko Gylling vielä 1910-luvun alkupuolella väestönkasvuun vaikuttaneita muutoksia kaupunki- ja maaseutuväestön ikä- ja sukupuolirakenteessa sekä avioitumisessa. Vuosikymmenen loppua kohti hänen väestöanalyysinsä kuitenkin terävöityi selvästi. ${ }^{576}$

1900-luvun alussa ulkoinen muuttoliike sai runsaasti huomiota mutta sisäistä muuttoliikettä tutkittiin varsin vähän. Gylling oli poikkeus, sillä hän käsitteli siirtolaisuuden molempia muotoja ja piti maassamuuttoa vähintään yhtä tärkeänä ilmiönä kuin maastamuuttoa. Tämä johtui ilmeisesti siitä, että sisäinen muuttoliike liittyi väestöilmiöistä selvimmin kapitalismin kehitykseen. ${ }^{577}$ Molemmat siirtolaisuuden muodot olivat osa maatalouden kehityksen ja maaseudun sosiaalisten olojen kokonaisproblematiikkaa, joka oli Gyllingin keskeinen kiinnostuksen kohde.

1900-luvun alussa siirtolaisuuden syyksi esitettiin yleensä moraalisävytteisiä seikkoja. Gylling ja Kilpi poikkesivat tästä linjasta ja liittivät siirtolaisuuden talouden kehitykseen. ${ }^{578}$ Samalla he pyrkivät myös oikomaan siitä esitettyjä yksioikoisia väitteitä. Gyllingin siirtolaisuusartikkelit olivat kuitenkin yleisiä ja kansanomaiseksi tarkoitettuja katsauksia, jotka jäivät melko pintapuolisiksi. Kilpi meni siirtolaisuustutkimuksissaan syvemmälle. ${ }^{579}$

576 Pitkänen 1988, s.144-145.

577 Pitkänen 1988, s.155-156. Gylling ilmeisesti vaikutti A.E. Tuderiin ja Toivo. T. Kailaan, jotka tutkivat myös muuttoliikettä.

578 Kilpi katsoi Gyllingin tavoin, että siirtolaisuus liittyi murrosaikaan, minkä industrialistinen ja kapitalistinen kehitys sai aikaan vanhassa maanviljelysyhteiskunnassa. Kilpi, O. K., Suomen siirtolaisuus ja 19.vuosisadan kansantalous. Taloustieteellisiä tutkimuksia XXII. Helsinki 1917, s.50.

579 Pitkänen 1988, s.157. 
Gyllingin mukaan voimakas muuttoliike Pohjois-Amerikkaan osoitti, että kerran alkanut siirtolaisuus veti uusia joukkoja perässään ja ylläpiti jatkuvaa muuttoliikettä. Vuosien 1905-1907 voimakas nousukausi Pohjois-Amerikassa voimisti siirtolaisuutta ja sitä seurannut lama heikensi sitä. Tämä osoitti, että siirtolaisuuden voimakkuus sekä Suomesta että muista Euroopan maista oli riippuvainen ennen kaikkea Pohjois-Amerikan taloudellisten olojen muutoksista. Vasta toissijaisena tekijänä olivat oman maan taloudelliset olosuhteet. ${ }^{580}$

Gylling painotti sisäisen muuttoliikkeen vilkastumista teollistumiskehityksen myötä. Väkilukutaulukoista selvisi 1800-luvun lopulta lähtien, kuinka suuri osa seurakuntien jäsenistä oli syntynyt asuinkunnassaan, muussa kunnassa, samassa läänissä tai muussa läänissä. Gylling olisi halunnut tarkastella myös eri suuntiin kulkevien muuttovirtojen rakennetta, mutta niistä ei saanut tietoa. ${ }^{581}$

Gylling korosti sitä, että sisäinen muuttoliike oli toistaiseksi käsittänyt vain pientä osaa väestöstä mutta se oli 1800-luvun lopulla voimakkaasti lisääntynyt kaikissa osissa maata. Vuosien 1881 ja 1908 välisenä aikana lähes 1,7 miljoonaa ihmistä oli vaihtanut asuinpaikkaa. Sisäinen muuttoliike oli ollut ulkoista suurempaa lukuun ottamatta Vaasan ja Oulun läänejä, joiden muuttoliike kohdistui valtaosaltaan Pohjois-Amerikkaan. Vetävät taloudelliset tekijät olivat sisäisenkin muuttoliikkeen keskeinen syy. Gyllingin mukaan Helsinki oli jo "oikea kapitalistinen yhteiskunta", koska sinne suuntautui voimakas muuttoliike. Se oli kasvanut jatkuvasti 30 vuoden ajan, joskin laskukausina kasvu oli hitaampaa kuin nousukausina. Gyllingin mukaan erityisesti naisten lukumäärän nopea lisääntyminen selittyi kapitalismin pyrkimyksenä käyttää "helposti riistettäväksi taipuvaa ja huokeapalkkaista naistyövoimaa tuotannossa". ${ }^{582}$

580 Gylling, Edvard, Eräitä uusia tilastotietoja Suomen siirtolaisuudesta. YhtA 2/1910 (D), s.98-102.

581 Pitkänen 1988, s.156-157.

582 Gylling, Edvard, Väestön ryhmitys syntymäpaikan mukaan ja sisäinen muuttoliike Suomessa. Suomen Kartasto 24-28, VI. Helsinki 1911 (D), 
Vuonna 1911 Gylling kirjoitti suomenruotsalaisista ilmeisesti käynnissä olleen kansallisuuskeskustelun innoittamana. Hän johti kansallisuustunteen nousun kapitalistisesta kehityksestä tuotannossa ja yhteiskunnassa. Sosialidemokratia oli tulos samasta kehityksestä, mutta se pyrki yhdistämään koko maailman proletariaatin taisteluun kapitalismia vastaan. Gylling suhtautui kaksijakoisesti kansallisuusaatteeseen: yhtäältä kansallinen taistelu usein yhdistyi taloudellisen ja poliittisen sorron vastustamiseen mutta toisaalta se yleensä hämäsi proletariaattia ja laimensi luokkataistelua. Gylling painotti kuitenkin sitä, että sosialistien pitäisi perehtyä kansallisuuskysymykseen ymmärtääkseen sitä paremmin. ${ }^{583}$

Gyllingin mukaan tärkeimmät asiat kansakuntien kehityksestä saatiin väestötilastoista. Suomenkielisten ja ruotsinkielisten alueet olivat vakiintuneet jo varhaisessa vaiheessa uudisasutuksen myötä. Ruotsinkielisten suhteellinen osuus suomalaisista oli laskenut erityisesti vuodesta 1880 eteenpäin. Samalla kielialueet sekoittuivat keskenään. Taustalla oli teollistuminen ja kapitalistinen kehitys. Gylling vertaili ruotsinkielisiä alueita yhtäältä keskenään ja toisaalta suhteessa suomenkielisiin alueisiin. Ruotsinkielisten alueitten väestönkasvu oli vuosina 1749-1865 maan keskiarvoa heikompaa. Tämä selittyi sillä, että Pohjanmaata lukuun ottamatta ruotsinkielisen väestön asuinalueet olivat jo ajanjakson alussa olleet varsin tiheästi asuttuja. Yhtä tiheästi asuttujen suomenkielisten alueiden väestönkasvu ei ollut sen nopeampaa. Gylling päätteli tästä, etteivät väestönkasvun erot johtuneet rodullisista ominaisuuksista, vaan eri alueiden taloudellisista ja yhteiskunnallisista tekijöistä. ${ }^{584}$ Gylling katsoi, että kansallisuusaatteen kehittymisen taustalla oli ennen kaikkea kapitalistinen kehitys. Taloudellisten ja yhteiskunnallisten muutosten korostaminen aatteellisen kehityksen perustana oli täysin marxilaisen ajattelun mukaista.

s.45-48; Gylling, Edvard, Muutamia tilastotietoja Helsingistä. Työväen Kalenteri VII. 1913, s.235-238.

583 Gylling, Edvard, Statistiska bidrag till svenska folkstammens historia i Finland. Helsingfors 1911 (A), s.1-2.

584 Gylling 1911 A, s. 2-15; vrt. Pitkänen 1988, s.144. 
Gylling luennoi dosenttina yliopistossa syyslukukaudesta 1910 alkaen. Valitettavasti nämä luennot eivät ole säilyneet, mutta pintapuolisen kuvan niistä saa selonteoista, joita tehtiin yliopiston opettajien toiminnasta. Syksyllä 1910 Gylling luennoi kaksi tuntia viikossa aiheesta Suomen väestötilastosta 1700- ja 1800-luvuilla. Kuulijoita oli kuusi, joista viisi oli yliopiston kirjoissa. Kevätlukukaudella 1911 Gylling luennoi kaksi tuntia viikossa aiheesta Suomen maataloudellisesta kehityksestä ja maataloustilastollisista lähteistä 1700- ja 1800-luvuilla. Kuulijoita oli seitsemän, joista kuusi oli yliopiston kirjoilla. ${ }^{585}$ Syyslukukaudella 1911 Gylling luennoi kaksi tuntia viikossa Suomen torpparilaitoksen kehityksestä. Luento jakaantui seuraavasti: torppariasutuksen vanhemmat muodot Ruotsissa ja Suomessa; suurviljelyksen kehitys ja maaorjuus Itämeren alueen maissa; päivätyötorppalaitoksen synty Suomessa; torpparilaitoksen kehitys 1700-luvulla ja 1800-luvun alussa ja taantuminen vuosisadan lopulla; torpparireformit. Kuulijoita oli kahdeksan, joista kuusi oli yliopiston kirjoilla. Keväällä 1912 Gylling luennoi kaksi tuntia viikossa Suomen virallisen tilaston kehityksestä ja nykyisestä järjestyksestä. Kuulijoita oli viisi, joista neljä oli ylipiston kirjoilla. ${ }^{586}$ Syksyllä 1912 Gylling luennoi tunnin viikossa tilastotieteestä. Kuulijoita oli 12, joista 11 oli yliopiston kirjoilla. Samalla syyslukukaudella hän järjesti seminaaria, jossa oli viisi osanottajaa. Gylling jatkoi kevätlukukaudella 1913 luennointiaan tilastotieteestä, jälleen tunnin viikossa. Kuulijoita oli 16, joista yliopiston kirjoilla oli $14 .{ }^{587}$ Lukuvuonna $1913-1914$ Gylling luennoi tilastotieteen historiasta. Syyslukukaudella hän luennoi kaksi tuntia viikossa tilastotieteen vanhemmasta historiasta. Kevätlukukaudella Gylling luennoi kaksi tuntia viikossa tilastotieteen

585 Selonteko Keisarillisen Aleksanterin -yliopiston opettajain toiminnasta lukuvuonna 1910-1911. Helsinki 1911, s. 69-70.

586 Selonteko Keisarillisen Aleksanterin -yliopiston opettajain toiminnasta lukuvuonna 1911-1912. Helsinki 1912, s.77.

587 Selonteko keisarillisen Aleksanterin -yliopiston opettajain toiminnasta lukuvuonna 1912-1913. Helsinki 1913, s.78. 
uudemmasta historiasta. Kuulijoita oli sekä syksyllä että keväällä viisi, jotka kaikki olivat yliopiston kirjoilla. ${ }^{588}$

Gylling luennoi siis varsin monipuolisesti tilastotieteeseen ja suomalaiseen yhteiskuntaan liittyvistä ilmiöistä. Luennoilla olivat varsin vahvasti esillä myös maatalouden historiallinen kehitys ja ajankohtaiset asiat. Tilastotieteen vakiintumattomuus yliopistollisena aiheena näkyi pieninä kuulijamäärinä. Tilastotiede oli vielä pitkälti kansantaloustieteen aputiede, mutta Gylling pyrki todennäköisesti saamaan sille itsenäisemmän aseman.

Gylling ohjasi kansantaloustieteen laudaturtöitä ja toimi joko vastaväittäjänä tai esitarkastajana useimmissa aineen väitöskirjoissa vuodesta 1911 eteenpäin. Hän oli vuonna 1911 Karl Mannelinin väitöskirjan Finlands smörexport. En statistisk-ekonomisk studie vastaväittäjänä. Gyllingin vaativuutta osoittaa, että hän hylkäsi väitöskirjan, koska tekijä ei osoittanut omaperäisiä näkemyksiä ja tilastojen käyttö oli epätyydyttävää. ${ }^{589}$ Seuraavana vuonna Gylling tarkasti vastaväittäjänä Oscar Lundellin väitöskirjan Bidrag till den finska befolkningsstatistikens historia ja toimi kahden muun väitöskirjan esitarkastajana. Hän toimi vastaväittäjänä ja todennäköisesti tärkeänä taustavaikuttajana myös vuonna 1914 julkaistussa Toivo T. Kailan (1884-1961) väitöskirjassa Europan Venäjän väestösiirroista XIX vuosisadan lopulla. Gylling esitti nämä väitöskirjat hyväksyttäväksi. ${ }^{590}$

Väestötieteessä kiinnostuttiin yhä voimakkaammin syntyneisyydestä. Taustalla oli huoli siitä, miten saada väestönkasvu jatkumaan. 1900-luvun alussa nimittäin sekä hedelmällisyys että syntyneisyys olivat laskussa. ${ }^{591}$ Tästä kysymyksestä kiinnostui

588 Selonteko keisarillisen Aleksanterin -yliopiston opettajain toiminnasta lukuvuonna 1913-1914. Helsinki 1914, s.78.

589 Gylling, Edvard, lausunto teoksesta Mannelin, Karl, Finlands smöexport. Yhteiskuntataloudellinen Aikakauskirja (YhtA) 2/1912, s.116-117; Heikkinen - Mauranen 1985, s.101.

590 Selonteko keisarillisen Aleksanterin -yliopiston opettajain toiminnasta vuonna 1912-13, s. 78; Selonteko keisarillisen Aleksanterin -yliopiston opettajain toiminnasta vuonna 1913-14, s.78.

591 Pitkänen 1988, s.162. 
myös Edvard Gylling, jolta julkaistiin vuonna 1915 lyhyt, mutta merkittävä tutkimus Syntyneisyydestä ja väestön lisääntymisestä Helsingissä. Gyllingin mukaan kapitalismin luonne ja kehitys ilmenee ennen kaikkea taloudessa, mistä se kuitenkin leviää melkein kaikille yhteiskunnan alueille, myös väestökehitykseen. Tämä vaikutus näkyi parhaiten kasvaneessa muuttoliikkeessä, missä väestö muuttaa sinne, missä "kapitalistinen talouselämä enimmän tarvitsee työvoimaa lisäarvoa kasvattamaan”. Gylling tutki Helsingin väestökehitystä myös yhteiskuntaluokkien ja kansallisuuksien näkökulmasta. Hänen mukaansa jälkimmäinenkin oli tärkeätä, koska "kansalliskiihkoilijoiden" taholta oli tehty harhaanjohtavia väitteitä. Gylling osoitti perusteellisilla laskemilla ja tilastollisella analyysillä, etteivät rotu- ja kansallisuuserot merkitse paljoa Helsingin väestön lisääntymisessä kun sen sijaan taloudelliset olosuhteet ovat tässäkin huomattava, jopa pääasiallinen selittävä syy. Syntyneisyys oli Helsingissä laskenut 1800-luvun lopulta lähtien, kuten muissakin kaupungeissa. Helsingin väkiluku kuitenkin kasvoi maaseudulta tulevan muuttoliikkeen takia, mikä johti keski-ikäisten määrän kasvuun. Varakkaiden syntyneisyys oli pitkään ollut pienempi kuin kaupunkityöväestön, jonka syntyneisyys kuitenkin oli epävarmuuden ja puutteen takia alkanut myös voimakkaasti laskea. Gylling totesi, että työväenliikkeelle on huono asia, mikäli sen kehittynein osa ei kasva. ${ }^{592}$

A. E. Tudeer arvosteli Gyllingin tutkimuksen Yhteiskuntataloudellisessa Aikakauskirjassa. Hän epäili sitä, että aviollisen hedelmällisyyden eroja voitaisiin selittää niin yksiselitteisesti väestön varallisuuseroilla. Tudeer huomautti, että maaseudulta muuttaneen väestön käyttäytyminen on voinut poiketa kaupungissa pitempään asuneen väestön käyttäytymisestä. Lisäksi hänen mielestään hedelmällisyyserojen taustalla voi olla se, että maalta muuttanut väestö on terveempää ja voimakkaampaa kuin kaupungissa kasvaneet. ${ }^{593}$

592 Gylling, Edvard, Syntyneisyydestä ja väestön lisääntymisestä Helsingissä. Helsinki 1915 (A), s.3, 39-48.

593 Pitkänen 1988, s.165. 
Gylling laski tutkimuksessa - ilmeisesti ensimmäisenä Suomessa - väestön uusiutumiskykyä eli sitä, kuinka monta lasta naisten oli keskimäärin synnytettävä, jotta sen hetkinen sukupolvi uusisi itsensä. ${ }^{594}$ Gylling totesi myös sen, ettei syntyneisyyden aleneminen johda aina väkiluvun kasvun heikkenemiseen, koska sen rinnalla voi esiintyä vastaava kuolleisuuden aleneminen. Tällaisesta kehityksestä olivat esimerkkeinä muun muassa Saksan ja Ruotsin kehitys. Suomessakin erityisesti lapsikuolleisuuden vähentyminen oli voimakkaasti kompensoinut syntyneisyyden pienentymistä, joskaan se ei ilmeisesti riittänyt estämään väestönkasvun heikkenemistä. ${ }^{595}$

Gylling kirjoitti myös runsaasti artikkeleita suomalaisen suurhankkeen Tietosanakirja-sarjan kahdeksanteen ja yhdeksänteen osaan, jotka julkaistiin vuosina 1916 ja 1917. Artikkelit olivat lyhyehköjä asioiden ja käsitteiden selityksiä, mutta niistäkin löytyy joitakin varsin kiinnostavia näkökulmia.

Gylling kirjoitti myös Suomen väestöstä ja asutuksesta artikkelin, missä hän korosti historiallista lähestymistapaa tutkimustensa pohjalta. Gylling painotti kapitalistista käännettä 1800-luvun puolivälissä, mikä johti muun muassa nopeaan kaupungistumiseen ja

594 Pitkänen 1988, s.162-163. Kyseessä oli nettouusiutuminen, missä otetaan huomioon se, että osa lapsista kuolee ennen suvunjatkamisikää. Gylling päätyi laskelmissaan 2,7 lapseen. Verratessaan tulosta todelliseen tilanteeseen hän havaitsi hedelmällisyyden laskeneen Helsingissä jo sille tasolle, ettei sen hetkinen sukupolvi enää uusisi itseään. Tulokseen vaikutti suurelta osalta helsinkiläisnaisten alhainen avioituvuus. Kari Pitkäsen mukaan Gylling ei tosin tässä ottanut huomioon sitä, että kuolleisuuden vähentymisen seurauksena todennäköisesti suurempi osa 1910-luvulla syntyneistä saavuttaisi aikuisiän kuin mitä sen hetkisen kuolleisuuden perusteella vaikutti

595 Gylling, Edvard, Syntyneisyys ja lastenkuolleisuus Suomessa viime vuosikymmeninä. Yhteiskuntataloudellinen Aikakauskirja 2:1915 (B), s.81-86; Gylling saavutti tämän tuloksen laskemalla, kuinka suuri osa vuosina 1881-1905 syntyneistä oli saavuttanut viiden vuoden iän. Hän oli ilmeisesti ensimmäinen tutkija, joka suomalaista väestötilastoa käyttäen laski kohorttikuolleisuuslukuja - vaikkakin ne rajoittuivat viiteen ensimmäiseen vuoteen. Pitkänen 1988, s.163. 
tilattoman väestön merkittävään lisääntymiseen. ${ }^{596}$ Gylling erotteli tilattoman väestön suppean ja laajan määritelmän. Varsinaiseen tilattomaan väestöön kuuluivat vain ne, jotka saivat toimeentulonsa satunnaisilla työansioilla (eli suurin osa mäkitupalaisia ja mökkiläisiä, loiset, itselliset). Laajemmassa mielessä tilattomaan väestöön kuuluivat myös ne torpparit, käsityöläiset yms., joiden maa-alueella ei tullut toimeen. Gylling totesikin, että tältä väestöryhmältä puuttui tarkalleen määriteltävät rajat ja tunnusmerkit. Joka tapauksessa maaseudun alin kerros, jolle oli tyypillistä huono toimeentulo ja epävarma asema, oli kasvamassa. ${ }^{597}$

Gylling kirjoitti yhdessä Jaakko Forsmannin kanssa tilastotieteestä. Heidän mukaansa tilastotieteen tehtävät olivat matemaattisten metodien selvittäminen ja yhteiskunnallisten ilmiöiden havainnointi. ${ }^{598}$ He kysyivät tilastotieteen luonnetta lähinnä jälkimmäisessä mielessä - kuitenkaan selvää vastausta antamatta seuraavasti:

Tilastolukujen nojalla selvitellessään väestö-, moraali-, sivistysy.m. yhteiskuntaelämän ilmiöitä tilastotiede toimii eksaktina yhteiskuntaoppina... ja muodostaa täten tavallaan rungon muille yhteiskuntatieteille, sosiologialle, taloustieteelle y.m. ${ }^{599}$

Gyllingin usko tilastotieteeseen yhteiskunnallisten ilmiöiden selittäjänä ja poliittisen päätöksenteon ohjaajana oli varsin suuri. Hänen voi sanoa uskoneen siihen, että tilastotiede voi toimia pohjana jonkinlaiselle yhteiskunnalliselle insinööritieteelle, missä yhteiskunta näyttäytyy koneena, jota voidaan parantaa hallitusti ja suunnata haluttuun suuntaan. Gyllingillä tilasto oli se yhdistävä tekijä, johon nojautuivat sekä yhteiskuntatiede että politiikka.

596 Gylling, Edvard, Suomi (väestö ja asutus). Teoksessa Tietosanakirja 9. Toim. Wichmann, Yrjö et al. Helsinki 1917(A), s.541-546.

597 Gylling, Edvard, Tilaton väestö. Teoksessa Tietosanakirja 9. Toim. Wechmann, Yrjö et al. Helsinki 1917 (C), s.1593-1594.

598 Gylling, Edvard - Forsman, Jaakko, Tilastotiede. Teoksessa Tietosanakirja 9. Toim. Wechmann, Yrjö et al. Helsinki 1917 (B), s.1592-1593.

599 Gylling 1917 B. 
Gyllingin käsitystä tilastotieteestä valaisee parhaiten hänen kirjoittamansa artikkeli Numerojen yhteiskuntafilosofiaa. Hän kirjoitti seuraavasti ${ }^{600}$

Nykyajan yhteiskunta on niin monimutkainen kokoonpanoltaan, ettei minkäänlaista kokonaiskuvaa vallitsevista oloista voisi saada, jollei yritettäisi laskea ja lukujen muotoon pukea sen eri ilmiöitä. Tosin tämä tieto, jonka tilastoluvut antavat, on kaavamaista, kuin kirveellä veistettyä tai kuten usein uudenaikaiset maalaustaiteen tuotteet, vain hahmopiirteitä tarjoava. Mutta tilaston avulla voidaan kuitenkin mitata yhteiskuntarakenteen eri osat ja saada selvyyttä monimiljoonaisen ihmisjoukon kokoonpanoon ja toimintaan.

Gyllingin mukaan tilastoa tarvittiin ensinnäkin tiedon lisäämiseen ylipäätään ja toiseksi myös käytännön lainsäädäntö- ja hallintotyössä. Varsin positiivisesti hän toteaa, että tilaston avulla selviteltiin lainmukaista järjestystä ihmiskunnan toiminnassa, mikäli tarkasteltiin riittävän suuria joukkoja. Tilastotietojen osoittamista säännönmukaisuuksista ja muutoksista voitiin päätellä yhteiskunnan rakennetta ja muutosta. Gylling totesi kiinnostavasti, että esimerkiksi rikosten määrä pysyi suurin piirtein ennallaan, mikäli "kurjuudessa ja puutteessa elävien" määrä säilyi samana. ${ }^{601}$

Gyllingin mukaan yhteiskunnallisia ilmiöitä selvittävä tilastollinen työ oli alkutekijöissään muun muassa sen takia, että monipuolista aineistoa oli saatavissa vain harvasta maasta. Tämän takia kapitalismille tyypillisten tilastollisten lakien ja ominaisuuksien selvittäminen oli vaikeaa. Kuitenkin jo löydettyjä kapitalistisia lainalaisuuksia olivat muun muassa seuraavat: syntyneisyyden nopea aleneminen, rikkauksien kasaantuminen ja laajan köyhälistön syntyminen monenlaisine seurauksineen. Gylling muistutti siitä, että tilastolliset lainalaisuudet olivat erilaisia yhteiskunnallisen

600 Gylling, Edvard, Numerojen yhteiskuntafilosofiaa. Uuden ajan kynnyksellä XIX. Suomen työväen joulualpumi. Helsinki 1916 (B), s.44.

601 Gylling 1916 B, s.45-48. 
kehityksen eri vaiheissa. Kuitenkin tilasto tarjosi "vankan pohjan yhteiskuntaolojen arvostelulle". ${ }^{602}$

Gyllingin mukaan tilastojen pohjalta voidaan muodostaa rationaalista yhteiskuntateoriaa. Tieteenfilosofisesti hän oli kuitenkin pohjimmiltaan empiristi, koska hän alisti "yhteiskunnalliset lainalaisuudet" kerätyille tilastotiedoille. Tilastoista voitiin johtaa tietoja yhteiskunnallisista oloista, mutta yksinomaan päättelyllä se ei onnistu. Toisaalta tällaisten lainalaisuuksien etsiminen ylipäätään on tieteenfilosofisesti varsin positivistinen lähestymistapa. Gyllingin ajattelun taustalla oli kuitenkin ennen kaikkea marxilainen analyysi, jolla myös oli pyrkimystä tällaisiin yleistyksiin.

602 Gylling 1916 B, s.49-50. 


\section{Maatalouspoliitikko vaikeissa oloissa}

\section{Torpparikysymys vuoden 1916 valtiopäivillä}

Vuonna 1914 alkoi maailmansota, johon Venäjäkin joutui mukaan. Suomi julistettiin sotatilaan heti sodan alkaessa 31.7. 1914, jonka jälkeen eduskunta ei enää kokoontunut. Eduskunnan normaalin kolmivuotiskauden puitteissa järjestettiin vaalit vuonna 1916, mutta niiden jälkeenkään eduskunta ei kokoontunut ennen Venäjän vallankumouksia vuonna 1917. Eduskunnan lainsäädäntötoiminta oli näin mitätöity, ja myös maatalouspolitiikan kysymykset jäivät toistaiseksi pois sen käsistä. ${ }^{603}$

Venäjän ministerineuvosto päätyi syksyllä 1914 siihen, että maanvuokraajien vuokrasuhteiden jäädyttämistä oli jatkettava. Keisari allekirjoittikin lokakuussa 1915 "armollisen julistuksen, jolla torppia, lampuoteja ja mäkitupa-alueita koskevat vuokrasopimukset pidennetään”. ${ }^{604}$ Siinä vuokrasuhteet jäädytettiin siihen asti, kunnes asia saatiin lopullisesti järjestetyksi. Samalla senaatti määrättiin antamaan esitys lopullisesta järjestämisestä mahdollisimman nopeasti ja osoittamaan muitakin keinoja, joilla maanvuokraajien maanhankinta helpottui. ${ }^{605}$

Vaikka eduskunta ei ollut kokoontunut maailmansodan aikana, niin heinäkuussa 1916 järjestettiin kuitenkin eduskuntavaalit, joita silmälläpitäen SDP:n maatalouskomitea laati yksityiskohtaisen, 28 pykälää käsittävän lakiehdotuksen torpparivapautukses-

603 Tuominen 1958 s. 400; Vares 2006, s44.

604 Rasila 1970, s.207-209.

605 Asetuskokoelma 67/1915. 
ta. Lakiehdotus julkaistiin Työmiehessä ja Maanvuokraajassa helmikuun 1916 lopulla. Sen mukaan vuoden 1909 maanvuokraasetuksen tarkoittamalla maanvuokraajalla tuli olla halutessaan oikeus lunastaa tilansa omakseen lain määräämällä tavalla. Jos hän ei tahtonut tehdä tätä eikä myöskään jatkaa vuokrasuhdetta, hänen tuli saada maanomistajalta saatavansa ulos. Perintöosuudeksi tai muuten jatkuvalla vuokraoikeudella annettu vuokratila oli luovutettava viljelijänsä omaksi ilman lunastusta. Jos vuokratila kuitenkin sijaitsi siten, että sen erottaminen olisi ratkaisevasti vaikeuttanut päätilan viljelemistä, oli vuokranantaja oikeutettu lunastamaan tilan itselleen maksamalla maanvuokraajalle kuuluvan osuuden kaksinkertaisena. Maanvuokraajalle oli luovutettava metsää, laidunmaata ja kalavesiä aiempaa vastaavalla tavalla, kuitenkin siten, että maanomistajalle jäi niitä vähintään kotitarvetta vastaavat määrä. Vuokratilan lunastusarvoa laskettaessa oli maanvuokraajan omaksi laskettava hänen tai jonkun edeltäjänsä rakentamat rakennukset sekä tekemät raivaukset, viljelykset ja muut parannukset, samoin kuin se, mitä hän tilalla selvästi omistaa. Maanomistajalle kuului muun muassa maapohjan silloinen arvo, kun tila oli asetettu vuokrattavaksi. Se, mikä tilalla ei selvästi kuulunut kummallekaan, oli puolitettava. Jos maanomistaja ei hyväksynyt näin laskettua tilan perusarvoa, oli hänen ilmoitettava oma hintansa. Hänen ei ollut kuitenkaan hyvä määrätä liian korkeaa hintaa, sillä lasketun perusarvon ja maanomistajan ilmoittaman hinnan ero laskettiin ansiottomaksi arvonnousuksi. Jos maanvuokraaja piti näin saatua lunastusarvoa liian korkeana, hänellä voi vaatia osansa, jolloin maanomistaja joutui maksamaan hänelle myös hänen osuutensa tuosta arvonnoususta. Maanvuokraajan oli maksettava lopullinen lunastussumma 50 vuoden kuluessa viiden prosentin vuotuisella korolla. ${ }^{606}$

Ruotsalaisen Kansanpuolueen kansanedustaja, pankinjohtaja Emil Schybergson (1856-1920) arvosteli voimakkaasti SDP:n

606 Rasila 1970, s.226-228. Lakiehdotuksen perusteluna oli se, että valtion maanvuokrakomitean mietinnön tultua julkisuuteen kesällä 1914 oli tarpeen, että torpparienkin taholta tehtäisiin yksityiskohtaisempi ehdotus kuin vuoden 1912 valtiopäiville jätetty aloite. 
maatalouskomitean ehdotusta. Gylling vastasi tähän toteamalla, että Schybergson eli vielä suureksi osaksi "säätyvaltiopäivien aikojen porvareille ihanista muistoista". Nämä "vanhan järjestelmän miehet" pyrkivät myymään torppareille heidän oman raivaustyönsä tulokset. Gyllingin mielestä SDP:n maatalouskomitean ohjelma oli tasapuolinen ja kritiikki perustuu väärinkäsityksiin tai poliittiseen leimaamiseen. ${ }^{607}$

Tampereen torpparien edustajakokouksessa huhtikuussa 1910 oli perustettu Maanvuokraajien Liitto, jonka tuli työskennellä maanvuokraajien aseman kohottamiseksi sekä heidän etujensa valvomiseksi kaikilla sivistyksellisen, taloudellisen ja valtiollisen toiminnan aloilla. Liittoon saivat liittyä kaikki sen tarkoituksen hyväksymät henkilöt, joka merkitsi ovien avaamista puhtaasti poliittiselle toiminnalle ja kytkeytymistä myös poliittiseen työväenliikkeeseen. Maanvuokraajien Liiton yleinen merkitys jäi kuitenkin varsin vähäiseksi. ${ }^{608}$

Oskari Tokoi laati kesäkuussa 1916 järjestettävää Maanvuokraajien Liiton edustajakokousta varten kirjasen, jossa hän selosti sosialidemokraattien lakiehdotusta. Tokoi kirjoitti ensin maanvuokrakysymyksen aikaisemmista vaiheista, jonka jälkeen hän totesi, että nyt on tehtävä selvä pesäero vanhempaan aikakauteen ja astuttava uuteen aikaan. Hänen mukaansa sosialidemokraattien ehdotus perustui torpparien perimien oikeuksien ja heidän omaisuutensa suojeluun, kun taas maanvuokrakomitean ehdotus jättäisi heidät vaille turvaa. Edustajakokous asettui yksimielisesti SDP:n kannalle, joka tunnusti yksityisen omistusoikeuden mutta jonka mukaan vuokratilaan sisältyi sekä maanomistajan että vuokramiehen omaisuutta. Kokous kuitenkin laajensi hieman vuokramiehen omistusoikeutta todeten, että torpasta 50 vuotta yhtäjaksoisesti maksettujen verojen tulisi oikeuttaa erottamisen ilman lunastusta ja maanomistajalle ei tulisi antaa lunastusoikeutta edes silloin, jos vuokratilan erottaminen tuottaisi haittaa päätilan viljelykselle. Kokous antoi lopulta maan kaikille maanvuokraajil-

607 Gylling, Edvard (nimim. E.G), Torpparien oikeuksista väittelyä. Työmies 5.3.1916(C)

608 Rasila 1970, s.85-88. 
le julkilausuman, jonka mukaan torpparivapautus oli viimeinkin ratkaistava tyydyttävällä eli käytännössä SDP:n esittämällä tavalla. Julkilausuma tehtiin lähinnä lähestyviä valtiopäivävaaleja varten, sillä sen mukaan kaikki äänet oli käytettävä maanvuokraajien asian ratkaisemiseksi. Kirjasta jaettiinkin vaalipiireihin sillä perusteella, mikä kussakin niistä oli maanvuokraajaväestön määrä. ${ }^{609}$

Suomalainen Puolue, Nuorsuomalainen Puolue ja Ruotsalainen Kansanpuolue tiivistivät yhteistyötään torpparikysymyksessä. Puolueiden yhteinen valiokunta totesi, ettei tyydyttävää ratkaisua saada aikaan ilman kummankin osapuolen, maanomistajien ja maanvuokraajien, myönnytyksiä. Valiokunnan mukaan lopulliseksi päämääräksi oli asetettava vuokraviljelmien lunastaminen itsenäisiksi tiloiksi. Koska tämä ei kuitenkaan uskottu onnistuvan lähitulevaisuudessa, hallinto-oikeus täytyi turvata maanvuokraajille siten, että maanomistajan oikeuksia loukattiin mahdollisimman vähän. Valiokunta ei pitänyt tarpeellisena sitä, että kaikki vuokratilat olisivat tulleet lunastuslainsäädännön alaisiksi. Sen mielestä lain ulkopuolelle voitaisiin jättää sellaiset suuret vuokratilat, joiden haltijat ovat taloudellisesti turvatussa asemassa ja sellaiset pienet vuokratilat, joiden haltija sai pääasiallisen toimeentulonsa viljelmän ulkopuolelta. Näiden periaatteiden pohjalta valiokunta laati lakiehdotuksen, jonka mukaan vuoden 1909 asetuksen tarkoittama maanvuokraaja oli sopimuskautensa päättyessä oikeutettu saamaan viljelmänsä uudelleen vuokralle määrätyin ehdoin ja poikkeuksin. Kaikki kolme puoluetta hyväksyivät tämän ehdotuksen vaaliohjelmakseen torpparikysymyksessä. ${ }^{610}$

Gylling arvosteli voimakkain sanakääntein tätä ohjelmaa. Hänen mielestään se käytännössä ajoi pelkästään maanomistajan etua jakamalla torpparit ja mäkitupalaiset kahteen ryhmään, joista pienemmän asemaa parannettaisiin ja suuremman asemaa huononnettaisiin. Vain noin viidennes maanvuokraajista saisi joitakin parannuksia ja toisaalta heiltäkin otettaisiin ilman korvausta joitakin entisiä oikeuksia. Gyllingin kirjoituksella oli vahva vaa-

609 TA, SDP:n puolueneuvoston toimintakertomus v. 1916; Rasila 1970, s. 228 230.

610 Rasila 1970, s.230-236. 
lipropagandistinen sävy, kun hän vetosi torppareihin, että nämä äänestäisivät entistäkin enemmän sosialisteja. ${ }^{611}$

SDP voitti vuoden 1916 valtiopäivävaalit saamalla 103 edustajapaikkaa, mikä merkitsi eduskuntaenemmistöä ja samalla yllätystä useimmille asianosaisille. Tämän enemmistön mahdollisuudet määrätä maan lainsäädännöstä näyttivät kuitenkin varsin teoreettisilta, koska sota jatkui edelleen eikä valtiopäivien koollekutsumisesta ollut mitään varmuutta. Aika keisarin maanvuokra-aikaa pidentävästä manifestista maaliskuuhun 1917 merkitsi torpparikysymyksessä seisahtunutta vaihetta, missä lähinnä odoteltiin asian lopullista ratkaisua. Kaiken aikaa vuokraviljelmiä tosin ostettiin vapaaehtoisesti omaksi, mutta varsin hitaasti, joten lainsäädäntöteitse tapahtuva ratkaisu tuli yhä tärkeämmäksi. ${ }^{612}$

\section{Torpparien asialla vallankumouksien keskellä}

Maanvuokraaja-asiat saivat uuden käänteen, kun Pietarissa syntyi maaliskuun alussa 1917 lakkoja, jotka pian kärjistyivät mellakoiksi. Venäjän keisari Nikolai II määräsi 12.3. duuman hajotettavaksi. Duuma kuitenkin kieltäytyi noudattamasta käskyä ja nimitti väliaikaisen hallituksen hallitsemaan maata, kunnes erityinen koko kansaa edustava kansalliskokous päättäisi maan tulevasta hallituksesta. Tässä niin sanotussa maaliskuun vallankumouksessa Venäjän monisatavuotinen keisarillinen valtaistuin menetti valtansa, joka siirtyi lähinnä keskustalaisista ja maltillisista vasemmistolaisista koostuvalle hallitukselle. Sillä oli kuitenkin vastustajia sekä poliittisen kentän oikealla että vasemmalla laidalla. Suomessakin syntynyt valtatyhjiö aiheutti uuden tilanteen. Sosialidemokraatit pyrkivät ns. valtalain avulla siirtämään keisarin vallan Suomen eduskunnalle, lukuun ottamatta sotilas- ja ulkopoliittisia asioita. ${ }^{613}$

611 Gylling, Edvard (nimim. E.G.), Porvarillisten puolueiden vaaliohjelmasta torppariasiassa. Työmies 20.4., 28.4. ja 12.5.1916 (E).

612 Rasila 1970, s.238, 240-241.

613 En käsittele tätä kehitystä ja valtalain kohtaloa tarkemmin, koska se ei sisälly tutkimuksen kysymyksenasetteluun. Tästä on hyvä kuvaus esimerkiksi 
Venäjän yhteiskunnallisen järistyksen ensimmäiset värähtelyt herättivät myös Suomen. SDP omaksui seuraavina päivinä vallankumouksen suhteen luottavaisen, passiivisen ja joukkojen rauhoittamiseen tähtäävän menettelytavan. Sosialidemokraatit ajoivat aiemmin eduskunnassa hyväksyttyjen yhteiskunnallisten uudistusten kiireellistä toteuttamista, kansalaisvapauksien palauttamista, yleisvaltakunnallisen lainsäädännön kumoamista ja eduskunnan koollekutsumista. Ylipäätään puolue halusi vahvistaa eduskunnan asemaa, jotta se voisi viedä läpi sen yhteiskunnallisten uudistusten ruuhkan, jonka tosiasiallinen eduskunnan vallan puute oli aiheuttanut. SDP alkoi Gyllingin ja Kuusisen johdolla maaliskuun loppupuolella neuvotella Suomen poliittisesta tilanteesta ja hallituksen muodostamisesta. ${ }^{614}$

Koska Venäjän väliaikainen hallitus oli ottanut käsiinsä aikaisemmin keisarille kuuluneen vallan, oli suomalaisten saatava siltä selvitys Suomen uudesta asemasta. Suomalaiset päätyivät siihen tulokseen, että uudelta hallitukselta oli saatava venäläistämistoimenpiteitä edeltäneet olot palauttava julistuskirja. Väliaikainen hallitus allekirjoitti 20.3.1917 tämän niin sanotun maaliskuun manifestin, missä se vakuutti pitävänsä voimassa Suomen perustuslait ja kumosi yksitellen jokaisen niitä vastaan rikkoneen määräyksen. ${ }^{615}$

SDP oli saavuttanut vuoden 1916 vaalissa eduskuntaenemmistön, eivätkä porvarilliset puolueet olleet halukkaita muodostamaan hallitusta ilman sitä. Tämä oli sosialidemokraateille ongelmallinen tilanne, koska kautskylainen teoria ei hyväksynyt osallistumista kapitalistisen yhteiskunnan hallitukseen. Toisaalta tilanne oli poikkeuksellinen ja tilaisuus houkutteleva. Ortodoksisimmat kautskylaiset - kuten Valpas, Kuusinen ja Manner - vas-

teoksessa Upton, Anthony F., Vallankumous Suomessa 1917-1918. 1.osa. Jyväskylä 1980, s.137-194.

614 Ketola, Eino, Kansalliseen kansanvaltaan : Suomen itsenäisyys, sosiaalidemokraatit ja Venäjän vallankumous 1917. Helsinki 1987, s.29-34; Hentilä, Marjaliisa. Sovittelija. Matti Paasivuori 1866-1937. Työväen historian ja perinteen tutkimuksen seura. Helsinki 2013, s. 165-167.

615 Rasila 1970, s.243-244. 
tustivat hallitusneuvotteluita kun taas pragmaattisemmat henkilöt Tannerin ja Wäinö Wuolijoen johdolla kannattivat niitä. Gylling ei tässä kysymyksessä seurannut Valppaan ja Kuusisen linjaa, vaan kannatti hallitusneuvotteluiden jatkamista, vaikka kieltäytyikin hallituspaikasta. ${ }^{616}$ Hannu Soikkanen korostaa sitä, että hallituskysymys oli kaiken kaikkiaan varsin monimutkainen, eikä sitä voida yksiselitteisesti yhdistää vasemmisto-oikeisto -muuttujaan. ${ }^{617}$ Vaikka ei mitään yksiselitteistä tulkintaa voitaisikaan tehdä, näyttää kuitenkin siltä, että puolueen vasemmisto vastusti hallitusneuvotteluja oikeistoa voimakkaammin.

Monien vaiheiden jälkeen muodostettiin lopulta kaikkien puolueiden yhteishallitus, jossa paikat jaettiin tasan 6-6 sosialistien ja porvarien kesken. Ratkaisuvalta oli kuitenkin vasemmistolla, sillä senaatin talousosaston varapuheenjohtajaksi eli pääministeriksi tuli Oskari Tokoi. Voidaan todeta, että Tokoin johtama senaatti oli maamme ensimmäinen parlamentaarinen monipuoluehallitus. ${ }^{618}$

Vuoden 1915 keisarillinen maanvuokraesitys oli syntynyt ohi Suomen oikeusjärjestyksen. Tästä syystä maanvuokraajat pelkäsivät, että se oli kumoutunut maaliskuussa 1917 annetun manifestin myötä, jolloin häätöjen uhka tulisi varsin suureksi. Gylling kuitenkin huomautti, ettei maanvuokraesitystä mainittu maaliskuun manifestin kumoamien asioiden joukossa. Tästä hän päätteli, että maanvuokraesitys oli edelleen voimassa ja uskoi, ettei Tokoin hallitus pyrkisi kumoamaan sitä ennen "uutta, parempaa torppariratkaisua". Gylling korosti kuitenkin, että torpparien voimakas painostus asiassa oli edelleen tarpeen. ${ }^{619}$ SDP:n puoluetoimikunta asettikin torpparivapautusta valmistelevan komitean, jonka sihteeriksi Gylling valittiin. ${ }^{620}$

Kokoomushallituksen ohjelmaan sisältyi myös torppariohjelma, missä maanvuokraajille luvattiin lunastusoikeus tiluksiinsa

616 Paavolainen 1979, s.119-121.

617 Soikkanen 1975, s.202.

618 Soikkanen 1975, s.202-205; Ketola 1987, s.48-51; Hentilä 2013, s.168-170.

619 Gylling, Edvard (nimim. E.G) Torpparihäädöt. Onko äskeinen manifesti tehnyt ne mahdollisiksi? Työmies 11.4.1917(E)

620 TA, SDP:n puolueneuvoston pöytäkirjat 1917. 
sellaisilla ehdoilla, jotka turvaavat heille oikeuden tehdyistä parannuksista ja osuuden maanarvon noususta. Ympäripyöreydestään huolimatta yhteinen ohjelma osoittaa, että puolueet olivat viimeinkin päässeet kysymyksen suhteen yhteisille periaatteellisille linjoille. Yksityiskohdista oli kuitenkin vielä niin paljon erimielisyyksiä, ettei Tokoin hallitus saanut toteutetuksi torpparivapautusta. ${ }^{621}$

Sosialidemokraattienkaan keskuudessa ei oltu yksimielisiä ja varmoja häätökiellon jatkuvuudesta, varsinkin koska uutisia häätökäskyistä alkoi kuulua. Asia jouduttiinkin ratkaisemaan varsin pian, koska vuoden 1914 valtiopäivillä lepäämään jätetty esitys vuokrasuhteiden pakollisesta jatkamisesta oli valtiopäiväjärjestyksen mukaan käsiteltävä nyt kokoontuneilla valtiopäivillä. Lähinnä vanhasuomalaisten äänillä lepäämään jätetty lakiesitys vuokrasuhteiden jatkamisesta tuli eduskunnassa ainoaan käsittelyyn 18.5.1917. Sosialidemokraatit olivat lakiesityksen takana, vaikka Gylling puheenvuorossaan arvostelikin sitä. Hänen mukaansa lain merkitys olisi ollut suurempi vuonna 1914, mutta nykyisessä tilanteessa se antoi torppareille ja mäkitupalaisille varsin vähän eli parhaassakin tapauksessa kolme vuotta kestävän oikeuden asua tilallaan. Hän vaati edelleen sitä, että torpparien pitkällä raivaustyöllä pohjustettu asumisoikeus oli turvattava. Lakiesityksestä puuttui maanomistajan omistusoikeutta korostava toinen pykälä, minkä takia lähinnä ruotsalaisen puolueen oikeisto vastusti lain hyväksymistä. Laki kuitenkin vahvistettiin murskaavin numeroin $156-12 .{ }^{622}$

Gylling puolusti sosialistienemmistön politiikkaa valtiopäivillä, vaikkei "rajoitettujen toimintamahdollisuuksien" takia ehditty tehdä perinpohjaista uudistusta. Kuitenkin edistysaskeleita olivat muun muassa seuraavat saavutukset: alemmille virkamiehille oli annettu palkankorotus, kansan sivistämiseen osoitettiin lisävaroja, hätäaputöitä järjestettiin työttömille ja elintarvikepulaa

621 Rasila 1970, s.248-249.

622 I 1917 VP, ptk.1, s.276-277; Rasila 1970, s.249-250. 
lievennettiin määrärahalla. ${ }^{623}$ Lisäksi hän kannatti verouudistusta lisääntyneiden valtion menojen kattamiseksi. Gyllingin mukaan tässä oli vastakkain kauan vallinnut porvarillinen linja, joka otti lähinnä köyhälistöltä ja sosialidemokraattien linja, missä viimeinkin otettiin varakkailta ja suurtilallisilta. Tätä kautta valtio voitiin saada toteuttamaan suuria yhteiskunnallisia uudistuksia. Eduskuntavaalien tuloksesta riippuu se, kumpi verolinjasta voittaa. ${ }^{624}$

Porvarilliset puolueet eivät olleet valinneet pankkivaltuusmiesten jäseneksi sosialidemokraatteja, vaikka he edustivatkin valtiopäivin suurinta puoluetta. Kun SDP:llä oli nyt enemmistö valtiopäivillä, sosialidemokraatteja oli pakko valita pankkivaltuusmiehiksi. Gylling valittiin pankkivaltuusmiesten puheenjohtajaksi. Hänen johdollaan sosialidemokraatit arvostelivat voimakkaasti Suomen Pankkia ja sen toimivaa johtoa omien taloudellisten etujen ajamisesta ja keinottelijoiden suosimisesta. Myöhemmin Gylling esiintyi maltillisemmin, ja ilmeisesti arvostelussa olikin kysymys ennen kaikkea syksyn 1917 vaalitaistelusta. ${ }^{625}$

Vallankumouksellisten muutosten innoittamana ja vaalien lähestyessä Gylling kirjoitti syksyllä 1917 joitakin porvarillisia voimia voimakkaasti arvostelevia kirjoituksia. Työmiehen kirjoituksessaan hän totesi, että vallitsevassa yhteiskunnassa hallitsevat luokat pyrkivät saamaan valtiolta mahdollisimman paljon hyötyä mahdollisimman vähillä uhrauksilla. Esimerkiksi feodalismissa aatelisto oli veroista vapaa kun taas alustalaiset olivat raskaasti verotettuja. Gyllingin mukaan porvaristo ei ole ollut edeltäjäänsä huonompi hyötymisessä - varsinkaan Suomen "etevä ja häikäilemätön” porvaristo. Suomen valtiontaloutta oli hoidettu virkavaltaisen porvarillisesti, kun porvarillisen oikeuslaitokseen, porvarillisiin sivistyslaitoksiin, sotaväkeen, poliisiin ja vankilalaitokseen

623 Gylling, Edvard (nimim. E.G.), Vuoden 1917 rahasääntö. Valiokunnan ehdotus menosäännöksi. Työmies 22.9.1917 (G).

624 Gylling, Edvard (nimim. E.G.), Verotusolojen uudistuksen puolesta. Valtiovaroja yhteiskunnallisiin uudistuksiin. Työmies 1.10.1917 (H).

625 Kuusterä, Antti - Tarkka, Jukka. Suomen Pankki 200 vuotta I, Keisarin kassasta keskuspankiksi. Helsinki 2011, s. 418-425. 
upotettiin suuri osa valtion varoista. Sen sijaan suuria kansan joukkoja hyödyntäviin tarkoituksiin käytettiin varoja varsin vähän. Gyllingin mielestä maatalous, kauppa ja teollisuus saivat äänensä kuuluviin hyvin, mutta yhteiskunnallisten epäkohtien korjaamiseen ei löytynyt varoja. Tulot oli otettu pääosin välillisillä veroilla kansalaisilta kun taas omistamista on verotettu erittäin vähän. Gylling katsoi, että Euroopassa vain Venäjällä suosittiin yhtä yksipuolisesti rikkaita. Hänen mukaansa Suomen valtiosta hyötyivät lähinnä virkavalta ja "tuottajaluokat", eikä "köyhälistö", joka kuitenkin maksoi valtaosan veroista. Lopuksi Gylling korosti, että kun valta Suomessa siirtyy kansalle ja sen valitsemalle eduskunnalle, verot kerätään rikkailta kapitalisteilta ja "porvarillinen riistäjävaltio" loppuu. ${ }^{626}$

Gyllingin kirjoitti Työväen kalenteriin 1860-luvun nälänhädästä käyttäen sitä taitavasti porvarillisia puolueita vastaan. Gylling syytti nälänhädästä osittain senaattia ja valtiovarainministeri J. V. Snellmania, jotka näyttivät odottavan ihmettä pelastamaan vuoden 1867 satoa ja ostivat sen takia ulkomailta viljaa liian myöhään. Lisäksi "porvarillinen hallitus" salli kauppiaiden keinottelun viljalla ja metsällä, jolla he ottivat suuren osan vanhan talollisluokan omaisuudesta. Tämä johti siihen, että samaan aikaan kuin sadattuhannet kansalaiset kuolivat nälkään, niin maatalouden vienti maasta kasvoi selvästi. Gyllingin mukaan hallituksen olisi tuolloisissa poikkeusoloissa pitänyt puuttua kapitalismin pääperiaatteeseen, joka on "pidä itse vapaan kilpailun vallitessa huoli itsestäsi". Gyllingin mukaan nälkävuodet sysäsivät yhteiskunnallista kehitystä eteenpäin edistämällä maalaisväestön proletarisoitumista, mikä taas nopeutti kapitalistista kehitystä. Suomalaisen metsäkapitalismin häikäisevän nousun taustalla oli kuitenkin 1860-luvun "kuoleman aikojen synkkä varjo". ${ }^{627}$

Gylling käytti edellä mainitussa kirjoituksessa historiaa poliittisen argumentoinnin tukena, kun hän korosti porvarillisten

626 Gylling, Edvard (nimim. E.G.), Porvarillinen valtiontalous. Verotulojen uudistus välttämätön. Työmies 16.9.1917 (F).

627 Gylling, Edvard, Nälkävuodet. Puolivuosisataismuisto. Työväen Kalenteri XI (painettu 1918). 1917 (D), s.110-121. 
puolueiden yhteyttä tuolloiseen hallitukseen. Tällaista historian käyttöä politiikan tukena kutsutaan nykytutkimuksessa "historiapolitiikaksi", jossa toisiinsa kietoutuvat menneisyyden selittäminen, tulevaisuuteen vaikuttaminen sekä nykyisyydessä tapahtuva politikoiminen. ${ }^{628}$ On myös huomattava, että Snellmanin suorasukainen arvostelu oli 1900-luvun alkupuolelle saakka harvinaista, mikä heijastui myös nälkävuosien julkiseen käsittelyyn. Fennomaanisen yhtenäiskulttuurin nimissä nälkävuoden selitettiin yleensä kansaa yhdistävänä käännekohtana, jolloin nälkäkuolemasta oli julkisuudessa tullut suorastaan kansallishyve. ${ }^{629}$ Gyllingin antama kuva poikkesi jyrkästi nälkävuosista annetusta aiemmasta kuvasta.

Huolimatta Gyllingin lukuisista kirjoituksista ja myös monien muiden sosialidemokraattien pontevasta vaaliagitaatiosta SDP sai lokakuussa 1917 eduskuntavaalissa 92 paikkaa, mikä merkitsi vaalitappiota ja enemmistön menettämistä. Viljo Rasilan tilastollisen analyysin mukaan sosialidemokraattien vaalitappion taustalla oli ennen kaikkea maanvuokraajien äänestyskäyttäytyminen. Vuoden 1916 vaalien alla ollut häätöpelko lisäsi heidän äänestysaktiivisuuttaan. Sen sijaan vuoden 1917 vaaleissa se passivoitui ja mahdollisesti joiltain osin maanvuokraajia siirtyi porvarillisten puolueiden taakse. ${ }^{630}$

Syksyllä 1917 vallinnut sekava tilanne synnytti sosialidemokraattien puoluejohdon piirissä jatkuvaa keskustelua Venäjän tulevan vallankumouksen ja Suomen mahdollisen vallankumouksen välisestä riippuvuudesta. Puoluejohdossa ei juuri ollut innokkaita vallankumouksellisia, mutta toisaalta monet totesivat, että alhaalta päin tulevaa vallankumousta oli vaikea hillitä, jos Venäjällä puhkeaa vallankumous. Vaihtuvien tilanteiden mukana eri henkilöiden kannat myös muuttuivat nopeasti. Kaikkein johdonmukaisemmin aseellista vallankumousta vastaan olivat K. H.

628 Historiapolitiikasta tarkemmin Tilli, Jouni, Tiloja, linjauksia, retoriikkaa historiapolitiikan ulottuvuuksia. HAik 3/2009, s.280-287.

629 Forsberg, Henrik, Nälkäkuolema kansallishyveenä? HAik 3/2011, s.267280.

630 Rasila 1970, s.291-298. 
Wiik ja Gylling, jonka mielestä proletariaatin diktatuuri ei soveltunut Suomelle. ${ }^{631}$ Vaalitappion jälkeen puolueen vasemmistosiipi uskoi entistä vähemmän eduskuntatyön mahdollisuuksiin muun muassa jatkuvasti pahentuvan elintarvikepulan ratkaisemisessa. Vallankumouksellisia radikaaleja esiintyi ennen kaikkea työväen järjestys- ja punakaarteissa, joita oli syntynyt eri paikkakunnille ilman puolueen ja ammattiyhdistysliikkeen välitöntä vaikutusta. ${ }^{632}$

Puoluejohto alkoi valmistella poliittista ohjelmanjulistusta painostamaan porvarillista eduskuntaa. Kuusinen, Gylling ja Tokoi laativat lokakuun lopulla luonnoksen, jonka pohjalta tehtiin $\mathrm{Me}$ vaadimme -julistus. Sosialidemokraattien piirissä tiedettiin, että Venäjän vallankumouksellinen liike oli voimistumassa ja valmistautui ottamaan vallan käsiinsä. Kuitenkaan kehityksen suunnasta ei voitu olla varmoja, joten Me vaadimme -julistus laadittiin sellaiseksi, että menettelytavoista voitiin joustaa tilanteen mukaan. Siinä vaadittiin muun muassa elintarviketilanteen parantamista, kahdeksan tunnin työpäivää, torpparien välitöntä julistamista riippumattomaksi isännästään, porvarillisten kaartien hajottamista ja Suomen sisäpoliittista itsenäisyyttä. ${ }^{633}$

Johtavien sosialidemokraattien asenne maanvuokraajakysymykseen muuttui epävarmemmaksi poliittisen tilanteen jatkuvasti muuttuessa. Tähän vaikutti ennen kaikkea se, että joissakin työväenkokouksissa vaadittiin jälleen viljelyspakon toteuttamista. Lisäksi Kuusinen arveli, että ainakin suurempien torppien haltijat ovat sota-aikana ansainneen niin paljon, että ne voisivat ostaa maansa ilman mitään tukea. Kuusinen totesikin, että torpparivapautus pitäisi nyt ajaa läpi "puolivallankumoukselliselta" pohjalta. Ilmeisesti Me vaadimme -julistus lähtikin tältä pohjalta, koska siinä ei puhuttu torpparien itsenäistämisestä, vaan heidän tekemisestään riippumattomiksi isännistään. Puolueneuvosto kävi julistuksesta keskustelun, jonka keskiössä oli maanvuokraajakysymys.

631 Soikkanen 1975, s.244-245; vrt. Karl H.Wiiks Dagbok från storstrejken till upproret 1917-1918. Utgiven av Sten Lindman. Åbo 1978, s.13-14.

632 Salkola, Marja-Leena, Työväenkaartin synty ja kehitys punakaartiksi 2. Helsinki 1985, s.27-29; Ketola 1987, s.338-344.

633 Soikkanen 1975, s.242; Ketola 1987, s.350. 
Gylling oli sitä mieltä, ettei sitä voitu tällaisessa julistuksessa määritellä kovin yksityiskohtaisesti, kuten ei sitten tehtykään. Lopulta julistuksessa todettiin, että kaikki torpparit ja mäkitupalaiset pitää tehdä riippumattomiksi isännistään ja kaikki veronmaksu heille on heti lakkautettava. ${ }^{634}$

Venäjällä oikeiston kapinan aikana bolševikeille jaettiin aseita ja heidän johtajansa vapautettiin vankilasta. Bolševikit alkoivat valmistautua uuteen vallankaappausyritykseen, jonka kannatusta lisäsi edelleen kärjistyvät ongelmat. He onnistuivatkin kaappaamaan vallan Suomessa käytössä olleen gregoriaanisen kalenterin mukaan 7.11.1917, jolloin Venäjällä käytetyn juliaanisen kalenterin mukainen päivämäärä oli 26.10.1917.

Vallankumouksellisen tilanteen innoittamana Gylling pohti torpparikysymystä kirjoituksessaan Työmiehessä 7.11.1917, jossa hän täsmensi Me vaadimme -julistuksen sanomaa. Gyllingin mukaan julistuksen vaatimukset merkitsivät tosiasiassa torpparivapautuksen toteuttamisesta, vaikka yksityiskohdat ratkaistaankin myöhemmin lainsäädännön kautta. Gylling kuitenkin epäili sitä, voidaanko torpparivapautusta toteuttaa parlamentaarisesti, kun muidenkin maiden alustalaisvapautukset olivat lähes poikkeuksetta tapahtuneet ulkonaisen paineen pakottamana. Hänen mukaansa meilläkin porvarit "alkoivat kallistaa korvaansa uudistusvaatimuksille" vasta suurlakon ja torppariliikkeen synnyn jälkeen ja heidän asenteenaan oli edelleen jatkuva jarrutus. Saadakseen vaatimuksensa läpi maanvuokraajien oli taisteltava "kumouksellisen köyhälistön" riveissä, koska vasta vallankumous turvasi heille oikean vapautuksen. ${ }^{635}$ Gylling pitäytyi kirjoituksessaan uudella linjalla, missä ei enää vaadittu torppareiden itsenäistämistä vaan tekemistä riippumattomaksi isännistään.

Gylling ei vaatiessaan torpparivapautusta ajanut varsinaisesti aseellista vallankumousta, mutta kannatti kuitenkin ulkoparlamentaarista painostusta ja yksipuolista laitonta toimintaa. Gyl-

634 TA. SDP:n puolueneuvoston pöytäkirjat 28.10-30.10.1917; Rasila 1970, s.259, 301.

635 Gylling, Edvard (nimim. E.G.), Alustalaiset heti vapaiksi. Työmies 7.11. 1917 (I). 
lingin tässä kirjoituksessa käyttämä näin hyökkäävä retoriikka poikkesi selvästi hänelle tyypillisestä sävystä. Tämä voidaan tulkita siten, että Gylling tilanteen innoittamana hetkeksi asettui kannattamaan vallankumousta, mutta uudestaan harkittuaan alkoi vastustaa sitä. Tämän tulkinnan kumoaa kuitenkin se, että hän vielä noin kuukautta myöhemmin - samaan aikaan vastustaessaan puolueen elimissä aktiivisesti vallanottoa - toisti eduskunnassa kirjoituksensa keskeiset asiat. Kirjoituksen kovan sävyn tarkoitus olikin ehkä painostaa porvarilliset ryhmät nopeisiin uudistuksiin. Toisaalta Gylling tuntui uskovan, että alustalaisvapautusta oli erittäin vaikea toteuttaa parlamentista käsin ilman alhaaltapäin tulevaa painostusta. ${ }^{636}$

Valtiopäivien kokoonnuttua jälleen vuonna 1917 vähemmistöksi jäänyt sosialidemokraattinen eduskuntaryhmä ryhtyi valmistelemaan esitystä maanvuokralaiksi. Tällä kertaa vapautus piti kuitenkin järjestää siten, että torppareista tuli isännistään riippumattomia eikä itsenäisiä. SDP:n ryhmä toi eduskuntaan asiaa koskevan eduskuntaesityksen 17.12.1917, mutta se sai odottamattoman kohtalon. Valtiopäiväjärjestyksen mukaan perustuslain luonteisesta asiasta ei voitu tehdä eduskuntaesitystä vaan ainoastaan anomusehdotus. Vain hallitsija olisi voinut tehdä eduskuntaesityksen. Toisaalta eduskunta oli julistautunut korkeimman vallan käyttäjäksi ja tavallaan hallitsijaksi, joten olisi ehkä mahdollista ottaa esitys käsiteltäväksi. ${ }^{637}$

Tässä tilanteessa Gylling ehdotti, että esitys otettaisiin käsittelyyn. Suomalaisen puolueen Lauri Ingman ehdotti puolestaan, ettei asiaa käsitellä hallitsijan esityksen tavoin. Gylling totesi, että nyt on viimeinkin aika ratkaista lopullisesti vuosia esillä ollut torpparikysymys. Hän myös toisti Työmiehessä noin kuukautta aiemmin esittämänsä näkemyksen, jonka mukaan porvarit eivät välttämättä vapauta vapaaehtoisesti maanvuokraajia, sillä "historia opettaa meille, että alustalaisvapautukset... ovat vallankumouksen kautta

636 Gylling nimittäin kirjoittaa sisällissodan jälkeen tekemässään katsauksessa vallankumousyrityksen syistä, että "historian kokemus" tukee tätä käsitystä. Tämä katsaus on painettuna Hodgson 1974, s.32.

637 Rasila 1970, s.306. 
melkein kaikkialla läpiajetut ja toteutetut”. Gylling uhkasi, että mikäli torppareita ei vapauteta laillisesti, he löytävät toisen keinon. Hän muistutti, että monet heistä olivat jo lopettaneet maksamasta veroja isännilleen. Gyllingin kovasta argumentaatiosta huolimatta SDP:n ehdotus hävisi niukasti äänin 98-96, joten sitä ei edes lähetetty maatalousvaliokuntaan. ${ }^{638}$ Näyttää siis siltä, että muutama porvarillinen edustaja kannatti sosialidemokraattien ehdotusta.

Gyllingin kovassa retoriikassa ei ollut kysymys siitä, että hän olisi kannattanut väkivaltaista vallankumousta. Hän nimittäin toimi jatkuvasti sosialidemokraattisen puolueen sisällä vallankumousta vastaan. Pikemminkin puhe oli yritys painostaa porvarilliset edustajat hyväksymään torpparivapautus, jonka jälkeen joukkojen vallankumouksellinen paine vähenisi. ${ }^{639}$

Maatalousvaliokuntaan lähetettiin kuitenkin käsiteltäväksi useita porvarilliselta taholta tulleita aloitteita. Merkittävin näistä oli vanhasuomalaisten esitys, mihin sisällytetty lakiehdotus noudatti muutamin poikkeuksin vuoden 1914 maanvuokrakomitean laatimaa lakiehdotusta. Merkittävin muutosehdotus oli se, että tällä kertaa myös maanvuokraajalla olisi oikeus vaatia vuokratilaa lunastettavaksi, kun komitea olisi antanut tuon oikeuden vain maanomistajalle. Vaikka valiokunta työskenteli ahkerasti varsinkin ennen sisällissodan puhkeamista, mitään lopullista ratkaisua ei ehditty tehdä. Vielä tammikuussa 1918 eduskunnassa tosin keskusteltiin hallituksen lunastuslakiesityksestä, jonka sisältö viittasi lähinnä maalaisliittolaiseen ja nuorsuomalaiseen suuntaan. Siinä esitettiin kaikkien määriteltyjen ehtojen täyttävien vuokratilojen itsenäistämistä. Gylling totesi, että hallituksen esitys olisi ollut edistyksellinen 5-10 vuotta aiemmin, mutta nyt se ei sitä ollut. Hän paheksui voimakkaasti sitä, että yhteiskunta korvaisi maan ansiottoman arvonnousun maanomistajalle vaikka se oli itse oikeutettu saamaan sen. ${ }^{640}$

638 II 1917 VP, ptk., s.387-404.

639 Rasila 1970, s.309-110.

640 II 1917 VP, ptk., s.1040; Rasila 1970, s.306-313. 
Marraskuussa 1917 Venäjältä kantautui tietoja puna-armeijan suurista vaikeuksista taisteluissa valkoista armeijaa vastaan. Gylling huomauttikin, etteivät bolševikit välttämättä pystyisi pitämään valtaa itsellään. Hän ei nähnyt mitään pakottavaa syytä vallanottoon, joten puoluejohdon on tiukasti otettava puolue hallintaan ja estettävä punakaartin aseellinen toiminta. Gylling painotti valtalain hyväksymistä ja yhteiskunnallisia uudistuksia, jotka toteutuessaan hillitsisivät joukkojen vallankumousintoa. Gylling sai voimakasta tukea Wiikiltä. ${ }^{641}$

Suomalaisten sosialidemokraattien menettelytavat muotoutuivat varsin pitkälti itsenäisyystavoitteesta käsin, mikä osoittaa kansallisuusajattelun olleen puolueen käytännön politiikassa merkittävä tekijä, vaikkakin käsitettä "nationalismi" vältettiin sen porvarillisen alkuperän vuoksi. ${ }^{642}$ Gyllingin linjauksessa näkyi, että myös hän oli taipuvainen kansalliseen ajatteluun ja kannatti Suomen itsenäisyyttä.

Vasemmisto halusi pitää kiinni valtalaista ja Me vaadimme -julistuksesta, mutta porvarienemmistöinen eduskunta hylkäsi ne ja asetti kolmimiehisen porvarillisen valtionhoitajakunnan. Sosialidemokraattiset edustajat tuomitsivat tämän voimakkaasti. Gylling katsoi, että vasemmisto ja suurin osa Suomen kansasta huomaa, että taantumus yrittää tehdä tyhjäksi edellisen eduskunnan vaati-

641 Wiik 1917-1918 (1978), s.29-35; Tuomioja 1979, s.172-176.

642 Suomalaisten sosialidemokraattien kansallisuusajattelua tutkinut Jouko Heikkilä korostaa, että luokkataisteluideologia muodosti jokseenkin yksimielisesti hyväksytyn perustan, johon puolueen eri edustajat nojautuivat toiminnassaan. Vuosina 1905-1917 oli olemassa työväenliikkeen kansallinen linja, jonka eri versioina yhteistoimintalinja ja itsenäinen luokkataistelulinja ilmenivät. Viime kädessä molemmat pääsuuntaukset olivat olemukseltaan ja tavoitteiltaan kansallisia ja nojasivat luokkataisteluideologiaan. Suuntauksia ei siis erottanut suhtautuminen luokkataisteluun sinänsä, vaan Venäjän yhteiskunnallista ja poliittista kehitysastetta koskeva tilannearvio. Itsenäinen luokkataistelulinja vahvistui vähitellen, kun sisäpoliittinen vastakkainasettelu voimistui sosialidemokraattien ja porvarillisten puolueiden välillä. Heikkilä, Jouko, Kansallista luokkapolitiikkaa. Sosialidemokraatit ja Suomen autonomian puolustus 1905-1917. Historiallisia tutkimuksia 168. Helsinki 1993, s.355-359. 
mukset. Lisäksi osa vasemmistosta kiisti eduskunnan valtuudet, koska sen mielestä edellinen eduskunta oli hajotettu laittomasti. ${ }^{643}$

Sosialistijohtajat olivat valmiita vastavetoon porvarillisen eduskuntaryhmän politiikalle. Samaan aikaan yhteiskunnalliset ongelmat kärjistyivät edelleen. Niiden taustalla oli ennen kaikkea kasvava pula elintarvikkeista ja polttopuista. Keinot tilanteen ratkaisemiseksi olivat eri puolueilla erilaiset: sosialistit kannattivat markkinoiden säätelyä ja tarpeen vaatiessa pakkotoimiakin kun taas porvarilliset ryhmät luottivat varsin pitkälti markkinoiden toimintaan. Vuonna 1915 elintarvikkeiden ja polttopuiden hintasäätely poistettiin. Gyllingin mukaan ilman säätelyä polttopuun hinta nousisi niin korkealle, ettei köyhimmillä ollut varaa ostaa niitä. Sitä paitsi korkeatkaan hinnat eivät välttämättä taanneet polttopuun saatavuutta, koska maanomistajat saattaisivat keinotella ja odottaa hintojen jatkuvaa nousua. Gyllingin mielestä aiemmin vallinneet rajahinnat eivät myöskään turvanneet niiden riittävää saatavuutta, mutta ne estivät kiskurihinnat ja jättivät yleensä myyjille kohtuullisen voiton. Gylling esitti ratkaisuksi polttopuiden rahtimaksujen tilapäistä alentamista ja ääritapauksissa keinottelijoiden halkovarastojen takavarikoimista. ${ }^{644}$

Gyllingin mukaan myös elintarvikkeiden hintasäätelyn poistaminen johti samankaltaiseen tilanteeseen eli siihen, että vain varakkailla oli niihin varaa. Tosin rajahinnatkaan eivät tosin olleet ratkaisseet elintarviketilannetta, joten yhteiskunnan pitäisi ryhtyä tehokkaammin järjestämään niiden hankintaa ja kauppaa. Gylling ehdotti, että elintarvikekysymystä järjestämään perustettaisiin elin, jolla on riittävä auktoriteetti ja lailliset valtuudet tähän tehtävään. ${ }^{65}$

Gylling ei uskonut vapaiden markkinoiden oikeudenmukaisuuteen, muttei myöskään kannattanut hintasäätelyä. Hän vaati yhteiskuntaa kantamaan enemmän vastuuta siitä, että myös työ-

6431917 II VP, ptk., s.55-69.

644 Gylling, Edvard (nimim. E.G.), Rajahinnatko poistettava? Työmies 20.7.1915 (K).

645 Gylling, Edvard (nimim. E.G.),Voipula ja elintarvikekysymyksen järjestely. Työmies 15.10.1915 (M). 
väelle riitti elintarvikkeita ja polttopuita. Sama huoli vähäosaisten asemasta näkyi myös siinä, että Gylling vaati valtion verotuksen painopisteen muuttamista sellaiseksi, että "kansan syviltä riveiltä" verotettaisiin vähemmän mutta suuri- ja keskituloisilta entistä enemmän. ${ }^{646}$

Myös osuuskassojen toiminnasta Gylling löysi keinottelua. Hänen mukaansa ne olivat yhtäältä edistäneet "rahatalouden ja järkiperäisen maanviljelyksen kehitystä", mutta toisaalta synnyttäneet "kapitalistista keinottelua". Osuuskassojen keskusrahasto oli antanut osakkailleen korkeaa osinkoa, mikä ei kapitalismissa ollut sinänsä väärin. Gylling kuitenkin vastusti laajoja valtion tukia tällaiselle voitontavoittelulle, varsinkin kun lainarahasto oli nostanut osinkoa eduskunnan päätöksen vastaisesti. ${ }^{647}$ Gylling valitti toisessa kirjoituksessa sitä, ettei eduskunta ryhtynyt asiassa mihinkään toimenpiteisiin, koska eduskunnan pankkivaliokunnan enemmistö ei nähnyt siihen tarvetta. Tässä ilmeni se, että porvarit jatkuvasti estivät SDP:tä saamasta yhtään jäsentä tuohon valiokuntaan. ${ }^{648}$

Samaan aikaan kun Suomen sisäiset yhteiskunnalliset ongelmat kärjistyivät, niin paine vallanottoon kasvoi myös ulkoapäin. Venäjän bolševikkien johtaja V. I. Lenin kannusti suomalaisia sosialisteja yleislakkoon estääkseen mahdollisten apujoukkojen lähettämisen valkoisten kenraalien tueksi. Ulkoiset ja sisäiset tekijät vaikuttivat siihen suuntaan, että Suomessa syntyi yleislakko 14.11.1917. Kuusi päivää kestänyt lakko sai väkivaltaisen ja puolivallankumouksellisen luonteen, mikä vahvisti nopeasti tarvetta kaikkien porvarillisten voimien yhdistämiseen. ${ }^{649}$

SDP jakautui yleislakon puhjettua kahteen siipeen, joista maltillisempi ja suurempi pyrki oikeistosuuntauksen vastapainoksi

646 Gylling, Edvard (nimim. E.G), Kurjat verotusolomme. Työmies 17.6.1915 (J).

647 Gylling, Edvard, Osuuskassojen Keskuslainarahaston uusi osakemerkintä. Työmies 29.7.1915 (L).

648 Gylling, Edvard, Eduskunnan päätösten rikkominen. Kapitalististen voittoetujen lisäämiseksi osuuskassaliikkeen turvissa. Työmies 19.3.1916 (D).

649 Ketola 1987, s.361-362, 388. 
yhteistyöhön maalaisliiton kanssa. Gylling oli tämän linjan johtavia edustajia ja oli mukana neuvottelemassa maalaisliittolaisten kanssa. Yhteistyö synnytti tulosta, sillä 15.11. eduskunta päätti maalaisliiton johtajan Santeri Alkion (1862-1930, vuoteen 1898 Filander) ehdotuksesta käyttää korkeinta valtaa Suomessa. Tämä sosialistien, maalaisliiton ja muiden porvarillisten puolueiden itsenäisyysmiesten äänin hyväksytyllä toimenpiteellä estettiin korkeimman vallan siirtyminen valtionhoitajakunnalle tai senaatille. Tulosta voidaan luonnehtia sosialidemokraattien torjuntavoitoksi. ${ }^{650}$

Vuoden vaihteeseen tultaessa levottomuudet lisääntyivät eri puolilla Suomea. Samaan aikaan kuin alhaalta päin paine kasvoi, myös bolševikit painostivat SDP:n johtoa päättäväiseen vallanottoon. Oman arvaamattoman tekijänsä muodosti myös Suomessa oleva venäläinen sotaväki. Aktivistien johtajiin kuulunut Herman Gummerus (1877-1948) on muistellut, että itsenäisyyttä kannattanut Gylling toivoi hartaasti, että maa voitaisiin vapauttaa venäläisten sotajoukkojen turmelevasta vaikutuksesta ${ }^{651}$. Tämä olisikin vähentänyt merkittävästi äärivasemmiston innostusta aseelliseen toimintaan.

Gylling pyrki edelleen välttämään sisällissotaa ajamalla puolueen elimissä hallitusyhteistyötä maalaisliiton kanssa ja korostamalla jatkuvasti elintarviketilanteen parantamisen tärkeyttä. Hän joutui kuitenkin toteamaan, etteivät varsinkaan kaupunkien työläiset pysyneet järjestyksessä. ${ }^{652}$ Gylling toimi varsin johdonmukaisesti tilanteiden eri käänteistä aseellista vallanottoa vastaan. Kun puoluejohto lopulta taipui vallankumouksellisten radikaalien painostukseen ja hyväksyi vallanoton, Gylling vetäytyi vallankumouksesta syrjään. ${ }^{63}$ Loppujen lopuksi hän kuitenkin meni "solidaarisuussyistä" mukaan vallankumoushallitukseen, vaikka

650 Tuomioja 1979, s.173; Ketola 1987, s.376-377.

651 Gummerus, Herman, Jääkärit ja aktivistit. Sotavuosien muistelmia Tukholmasta ja Berliinistä. Porvoo 1928, s.470.

652 Wiik 1917-1918 (1978), s.76, 95-99,103; Tuomioja 1979, s.192-196

653 Soikkanen 1975, s.244-245; Wiik 1917-1918 (1978), s.45-52; vrt. Tuomioja 1979 , s.174-176. 
olikin aktiivisesti ja johdonmukaisesti vastustanut aseellista vallanottoa. ${ }^{654}$

Katse taaksepäin: myöhempi tulkinta sosialidemokraattisesta maatalouspolitiikasta

Suomen sisällissodan päätyttyä valkoisten voittoon Gyllingiä syytettiin osallistumisesta vallankumousyritykseen. Gylling kirjoitti kesäkuussa 1918 laajahkon muistion, jossa hän puolustautui häntä esitettyjä syytöksiä vastaan ja esitti oman tulkintansa tapahtumien kulusta. Gylling ilmeisesti harkitsi ilmoittautumista Turun hovioikeudelle, mutta luopui siitä todettuaan tuomioiden ankaruuden ja mielivaltaisuuden. ${ }^{65}$

Gylling kirjoittaa siinä varsin laaja-alaisesti 1900-luvun alun Suomen poliittisesta kehityksestä, erityisesti sisällissodasta ja omasta roolistaan siinä. Hänellä ei ollut käytettävissä mitään lähteitä tai kirjallisuutta, vaan kirjoitus on laadittu muistinvaraisesti. Gylling ottaa lähtökohdakseen epäonnistuneen vallankumousyrityksen, joka hänen mukaansa mursi työväenliikkeen saavutukset niin täydellisesti, että sen työtä jatkavan liikkeen tulee lähteä aatteellisesti uudelta pohjalta, vaikka toiminnassaan se pitkälti nojaakin aiemman perintöön. Suurimman osan muistiosta viekin vuosien 1917-1918 sisällissotaan johtaneen kehityksen ja tapahtumien yksityiskohtainen kuvaaminen. ${ }^{656}$

Tämän tutkimuksen kannalta on kiinnostavaa analysoida sitä, millainen oli Gyllingin näkemys maatalouden oloista ja niiden vaikutuksesta yleisempään poliittiseen tilanteeseen ja sitä kautta sisällissodan syntymiseen. Gylling käsittelee näitä asioita muistion alussa luodatessaan yhteiskunnan kehittymistä ja työväenliikkeen syntyä 1900-luvun alussa. Gyllingin itseymmärryksen kautta on

654 Rinta-Tassi 1986, s.95-97,121-122,158.

655 Ylärakkola 1976, s.138-140; vrt. myös Paavolainen 1979, s.216-217.

656 Gyllingin kirjoittama muistio on painettuna Hodgson 1974, s.26-62. 
mahdollista avata näitä asioita uudesta näkökulmasta, joka on subjektiivisuudessaankin varsin analyyttinen.

Gylling toteaa muistiossa, että kapitalismin kehittyessä työväenluokka tulee aina tietoiseksi luokka-asemastaan ja luokkaeduistaan, jonka jälkeen se alkaa itse ajaa omia tavoitteitaan. Sosialistinen työväenliike on kansainvälistä alkuperää, mutta se sai Suomessa omintakeisen leiman maaseutulähtöisyytensä takia. Suomi oli taloudellisesti kehittymättömämpi kuin muu LänsiEurooppa, joten teollisuus- ja kaupunkiväestö oli täällä vähäistä. Maaseudun merkitys oli sen sijaan suuri, vaikka "agraariolot" olivatkin vielä "puolifeodalisella" kannalla ja "mennyttä aikaa edustanut" torpparilaitos oli murrostilassa. Gyllingin mukaan säätyvaltiopäiviltä oli jäänyt alkeellisinkin torpparivapautus tekemättä, joten "torpparien ja heidän veroistensa" (tarkoittanee muita maanvuokraajia) tyytymättömyys kanavoitui työväenliikkeeseen, joka todella myös ajoi heidän asiaansa. Hän kuitenkin totesi, että sosialidemokraattienkin ohjelmissa esitetyt vaatimukset torpparien aseman parantamisesta olivat epätyydyttävät. Suomen maaseudulla oli maanvuokraajien lisäksi myös vielä paljon tilatonta väestöä, koska kaupungistuminen oli vasta alkutekijöissään. Sosialidemokraatit saivat paljon kannatusta myös heiltä. ${ }^{657}$

Gyllingin analyysin mukaan nämä maaseudun väestöryhmät eivät lisäänny kapitalismin kehittyessä, toisin kuin teollisuustyöväki. Näille maaseudun ryhmille ei ole suurta arvoa ammattiyhdistysliikkeen vahvistumisesta ja työväkeä edistävästä lainsäädännöstä. Valtiollinen uudistuslainsäädäntö voi hyödyttää maanvuokraajia, mutta ei niinkään tilatonta väestöä, varsinkin kun vaikuttavimmat toimenpiteet - kuten viljelyspakko - ei olleet käytännössä toteutettavissa. Gyllingin mukaan tämä johtaa siihen, että molempien väestöryhmien toiminta purkautuu helposti vallankumouksellisen toiminnan ja jopa anarkismin suuntaan, vaikkei tilattomalla väestöllä ole paljon saatavaa vallankumouksenkaan kautta. ${ }^{65}$

657 Hodgson 1974, s.27-30.

658 Hodgson 1974, s,30-31; Sulo Wuolijoki kirjoittaa pari vuosikymmentä myöhemmin torpparikysymyksestä ja on samaa mieltä siinä, ettei viljelys- 
Gylling kirjoittaa, että sosialidemokraattien tuella saatiin aikaan yleinen ja yhtäläinen äänioikeus. Tämän jälkeen eduskunta teki paljon tärkeitä uudistuslakeja, joilla parannettiin yhteiskunnan toimintaa. Sosialidemokraattien organisointi- ja valistustoiminta työväestön keskuudessa oli myös menestyksellistä. Hän nostaa kuitenkin esille sen, ettei puolue saanut aikaan näitä suuria maalaisryhmiä koskevia uudistuksia. Puolue luopui viljelyspakosta, joka kohtasi suurta vastarintaa porvarillisten puolueiden taholta. Hänen mukaansa muita puolueita ei saatu taipumaan myöskään oikean torpparireformin taakse. Sen syntymisen esti lopulta myös sotatila, jonka aikana eduskuntaa ei kutsuttu koolle. ${ }^{659}$

Gylling arvioi, että näiden epäonnistumisten takia radikaalin maalaisväestön kumouksellisuus kasvoi entisestään. Maaseudulla alkoi raju maatyöväenliike keväällä 1917, joka johti lakkoihin, joita puolue ei pystynyt hallitsemaan. Hänen mukaansa eri osissa maata alkaneet sotilastyöt työllistivät paljon "järjestäytymätöntä maalaisrahvasta", joka yhdistettynä niissä oleviin huonoihin oloihin lisäsi "kuritonta henkeä". Gylling toteaa kuitenkin, että maatyöväellä oli paljon syytä valittaa, kuten pitkät työpäivät ja elinkustannusten nousuun verraten pienet palkat. Vallankumouksellisten voimien vahvistumiseen vaikuttivat hänen mukaansa myös Venäjän uudistuslait estänyt sortopolitiikka, suurporvariston ankara taantumuksellisuus, sotatilan aiheuttava toimintavapauksien vähentäminen sekä yleinen hintojen kohoaminen ja elintarvikekysymys. ${ }^{660}$

Gyllingin tekemästä muistiosta näkyy erittäin analyyttisen tiedemiehen ote, jossa asioita perustellaan ennen kaikkea järkiperäisesti, tunneilmaisujen jäädessä vähemmälle. Muistio on totta

pakko ollut toteutettavissa, koska sosialidemokraateilla ei ollut tarpeeksi voimaa. Wuolijoki, Sulo, Torpparivapautus. Helsinki 1939, s.41.

659 Hodgson 1974, s.31-32.

660 Hodgson 1974, s.32-36.; K.H.Wiik kirjoitti myös sisällissodan jälkeen sen taustoista ja tapahtumista. Wiikin antama kuva tapahtumien kehityksestä ja maatalouden tilattoman väestön osuudesta siinä on samantyyppinen kuin Gyllingin. Ks. tarkemmin Wiik 1919, s.29-38,56-60. 
kai subjektiivinen tulkinta, mutta ainakin sosialidemokraattisen puolueen maatalouspolitiikan osalta varsin oikeaan osuva. 


\section{Edvard Gylling maatalouspolii- tikkona suurlakon ja sisällissodan välisenä aikana}

Olen tässä tutkimuksessa selvittänyt Edvard Gyllingin maatalouspoliittista ajattelua ja toimintaa suurlakon ja sisällissodan välisenä aikana. Pyrin luomaan hänen maatalouspolitiikkaan liittyvästä roolistaan ja toiminnastaan kokonaiskuvan vastaamalla tutkimuksen kysymyksiin. Samalla peilaan tutkimuksen kautta syntynyttä kokonaiskuvaa aiempaan käsitykseen Gyllingin maatalouspoliittisesta ajattelusta ja toiminnasta. Tutkimuksen pääkysymys on seuraava: Mikä merkitys Edvard Gyllingin maatalouspoliittisilla näkemyksillä ja toiminnalla oli sosialidemokraattisessa puolueessa ja sitä kautta laajemmin yhteiskunnassa?

Edvard Gylling on aiemmassakin tutkimuksessa nostettu yhdeksi SDP:n maatalouspolitiikan keskeisimmistä asiantuntijoista. Tämä tutkimus vahvistaa ja täsmentää tätä kuvaa. Gyllingin toiminnassa yhdistyi vahva tutkimusosaaminen käytännölliseen poliittiseen toimintaan. Gylling oli vakiojäsen erilaisissa aiheeseen liittyvissä komiteoissa ja selvitysryhmissä. Hän käytti aiheesta myös useita puheenvuoroja valtiopäivillä ja kirjoitti siitä lukuisia artikkeleita eri lehtiin. SDP:n maatalouspoliittisiin linjauksiin vaikuttivat tietysti Gyllingin lisäksi puolueen muutkin johtajat ja asiantuntijat, erityisesti maatalouskysymyksiin perehtyneet Oskari Tokoi ja Sulo Wuolijoki. Heidän toimintansa tuloksena sosialidemokraatit saivat vahvaa tukea maanvuokraajilta ja varsinaiselta tilattomalta väestöltä.

Gylling oli pitkään ensisijaisesti tiedemies, mutta vähitellen poliittinen toiminta alkoi viedä yhä suuremman osan hänen ajastaan. Hänet valittiin useille valtiopäiville, minkä lisäksi hänestä 
tuli SDP:n johtopiirin jäsen. Tämä on sinänsä tyypillistä: yhdistelmä tiedemies ja poliitikko oli 1900-luvun alussa varsin yleinen ilmiö. Sitä paitsi Gyllingin tutkimustoiminnassa oli alusta alkaen mukana vahva yhteiskunnallinen ulottuvuus.

Maanvuokraajien ja varsinaisen tilattoman väestön ongelmat sisältävä maatalouskysymys oli 1900-luvun alun laajin ja vaikein sisäpoliittinen ongelma. Se oli myös asia, joka selvimmin yhdisti Gyllingin tieteellisen ja poliittisen toiminnan toisiinsa. Teollisuuden kehityksen arvioiminen oli 1900-luvun alun kansainväliselle työväenliikkeelle huomattavasti helpompaa kuin maatalouden kehittyminen, joka ei näyttänyt noudattavan Karl Marxin keskittymisteoriaa. Marxin keskittymisteorian mukaan suurtuotannon piti syrjäyttää pientuotanto maataloudessakin, mutta kehitys ei yksiselitteisesti tukenut teoriaa. Sosialistisessa liikkeessä syntyi kiista, miten tähän olisi suhtauduttava. Karl Kautskyn mielestä suurviljelys syrjäytti pitkällä aikavälillä pienviljelyksen kun taas revisionistit Eduard Bernsteinin johdolla katsoivat kehityksen osoittaneen Marxin teorian vääräksi. Suomen sosialidemokraateille maatalouden suuntaa koskeva ongelma oli erityisen tärkeä, koska Suomi oli 1900-luvun alussa vielä vahvasti maatalousvaltainen maa.

SDP:n ohjelmat ja politiikka nojasivat yleisesti ottaen selvästi marxilaiseen teoriaan ja sen kautskylaisiin tulkintoihin. Toisaalta maatalouskysymys agraarisessa Suomessa oli sosialidemokraateille sekä erittäin tärkeä että erityisen vaikea. Tilaton väestö halusi yleensä oman tilan, mikä taas ei sopinut sosialismin teoriaan. Tämän takia puolueen linja oli tässä kysymyksessä pragmaattinen ja mukautuva, välillä varsin sekavakin.

Gylling nousi vuoden 1905 suurlakon jälkeisinä vuosina sosialidemokraattien maatalouspolitiikan johtavaksi asiantuntijaksi ja linjanvetäjäksi, jonka asiantuntemusta käytettiin laajasti eduskuntatyössä, torpparikokouksissa ja puolueen työryhmissä. Hän oli keskeinen henkilö siinä, että viljelyspakkovaatimuksesta tuli sosialidemokraattien tärkein maatalouspoliittinen vaatimus vuonna 1906. Viljelyspakko tarkoitti sitä, että jos maanomistaja ei viljele viljelyskelpoista maataan, hänen on jätettävä se haluk- 
kaalle vuokraa vastaan viljeltäväksi. Tätä kautta tilattomat saisivat maata uudisasutukseen ja pienviljelijöille tulisi mahdollisuus viljelyksen suurentamiseen. Viljelyspakon kautta oli mahdollista ratkaista maatalouskysymys lisäämättä maanomistajien määrää, mutta toisaalta sen toteutuminen olisi merkinnyt pienviljelmien lisääntymistä. Sosialistinen teoria sai siis väistyä pragmaattisen politiikan tieltä. Samalla SDP sai nousevan maanvuokraajaliikkeen vahvan tuen, mikä osaltaan selittää sen nopeaa nousua suurimmaksi puolueeksi.

Vuoden 1909 maanvuokralaki jäädytti vuokrasuhteet vuoteen 1916 asti. Tänä aikana oli tarkoitus saada ongelma lopullisesti ratkaistuksi. Uusi maanvuokralaki oli kompromissi, johon mikään ryhmittymä ei ollut täysin tyytyväinen. Oikeiston mukaan se sorti omistusoikeuden ikuisuuden periaatetta vastaan, vasemmiston mielestä tilanne säilyi melkein yhtä huonona kuin ennenkin ja keskustan mielestä asetus oli osittain jopa vahingollinen. Puolueista se vastasi kuitenkin lähinnä vanhasuomalaisten ja maalaisliiton kantoja.

Gylling katsoi, että uusi maanvuokralaki paransi tilannetta vain osittain. Myönteistä oli se, että laki pidensi kaikkien vuokramiesten sopimusta vähintään seitsemällä vuodella ja vähensi maanomistajan mielivaltaista häätöoikeutta. Lisäksi maanvuokraajalle määrättiin korvaus viljelysparannuksista ja rakentamistaan tarpeellisista rakennuksista. Vuokramies sai hoitaa tilansa viljelyksiä oman harkintansa mukaan eikä vuokranantaja voinut estää viljelysparannusten käyttöön ottoa. Myönteinen muutos oli myös se, että vuokramiehelle annettiin mahdollisuus vapautua työverosta ja suorittaa maksunsa rahassa. Gyllingin mielestä laissa kuitenkin turvattiin maanvuokraajien asema vain verrattain lyhyeksi ajaksi eikä säädetty liian suurten vuokramaksujen alentamista. Lisäksi hän löysi siitä sekä feodalismiin viittaava holhousta että maanomistajia suosivia tulkinnanvaraisuuksia. Gylling uskoi kuitenkin, että uusi maanvuokralaki voikin olla vain ensimmäinen askel, jota perinpohjaisemmat muutokset lähitulevaisuudessa seuraavat.

Gyllingin johdolla SDP:ssä peräännyttiin viljelyspakkovaatimuksesta, koska sen ei uskottu olevan realistinen vaatimus por- 
varillisten puolueiden jyrkän vastustuksen takia. Uusikaan linja ei ollut varsinaisesti sosialistinen. Vuodesta 1911 alkaen sosialidemokraatit pyrkivät tekemään maanvuokraajista tilojensa omistajia, vaikka eivät edelleenkään periaatteessa hyväksyneet yksityistä maanomistusta, mutta uskoivat sen turvaavan maanvuokraajan työn ja omaisuuden niin hyvin kuin se on mahdollista kapitalistisessa yhteiskunnassa. Tämän jälkeen SDP vetosi maanvuokraajien "varsinaiseen asumisoikeuteen" tilojensa suhteen, minkä perusteella heidän pitäisi itsenäistää hyvin ehdoin. Varsinaisella asumisoikeudella tarkoitettiin ilmeisesti lähinnä raivaajan oikeutta raivaamaansa alueeseen silloin, kun hän ei ollut tehnyt sitä toisen palkkaamana eli ensisijaisesti työn tulosten omistusoikeutta. Siihen sisältyi myös suoranainen oikeus, mikä perustui esimerkiksi perintöön tai ostoon. Laki ei tuntenut tämänlaista varsinaista asumisoikeutta, vaan sen kannalta kysymys oli joka tapauksessa tavallisesta maan käyttöoikeudesta, mikä päättyi vuokrasopimuksen loppuessa. Porvarilliset puolueet eivät tällaista asumisoikeutta tunnustaneet.

Sosialidemokraatit ja porvarilliset puolueet olivat tämän jälkeen samaa mieltä torpparien itsenäistämisen tarpeesta, mutta keinoista vallitsi suuri erimielisyys. Puolueet eivät saaneetkaan ratkaistua torpparikysymystä ennen ensimmäistä maailmansotaa. Myöskään varsinaisen tilattoman väestön aseman parantamisessa ei juuri edistytty. Suomen sisällissodan jälkeinen niin sanottu tynkäeduskunta hyväksyi heinäkuussa 1918 torpparilain, joka antoi maanvuokraajille oikeuden lunastaa vuokratilansa.

Olen tutkinut myös sitä, miten Gyllingin tieteelliset ja maatalouspoliittiset näkemykset muuttuivat eri tilanteissa ja ajan kuluessa. Hän tutki aktiivisesti maatalouden kysymyksiä, erityisesti maanvuokraajien ja varsinaisen tilattoman väestön asemaa. Hän myös julkaisi aiheesta pro gradu -tutkielman, väitöskirjan, runsaasti tieteellisiä artikkeleita ja paljon poliittisia kirjoituksia.

Gyllingin tutkimustyön kautta saama tieto oli merkittävää hänen maatalouspoliittisen toimintansa kannalta. Gylling oli poliittisesti 1900-luvun ensimmäisinä vuosina tyypillinen porvarillinen suomenmielinen ylioppilas, joka kiinnostui kuitenkin 
sosialismista ja liittyi työväenliikkeeseen vuonna 1905 ennen suurlakkoa. Gylling oli SDP:hen liityttyään ensin jonkinlainen sosiaalireformisti, mutta suurlakon jälkeen hän lähestyi selvästi marxilaisuutta, jonka pohjalle hän rakensi itsenäisesti omat yhteiskunnalliset analyysinsä. Gylling ei missään vaiheessa ollutkaan sellainen dogmaatikko kuin esimerkiksi vanhan työväenliikkeen paaviksikin mainittu Edvard Valpas, joka pyrki aina johtamaan poliittisen toiminnan mahdollisimman suoraan teoriasta.

Gyllingin maatalouspoliittiset näkemykset alkoivat muodostua hänen opiskellessaan Helsingin yliopistossa. Suurin vaikutus hänen ajatteluunsa oli maanviljelys- ja kansantaloustieteen dosentti Hannes Gebhardilla, joka oli porvarillinen sosiaalireformisti ja halusi iskostaa oppilaisiinsa maareformin tärkeyden. Gebhardin ajattelun pohjautui kansantaloustieteen historiallisen koulukunnan näkemyksiin, joissa arvosteltiin klassista taloustiedettä historiallisen taustan väheksymisestä. Sen edustajien mukaan kunkin maan taloutta pitäisi tarkastella sen omien instituutioiden, sosiaalisten käyttäytymismallien ja kulttuuristen asenteiden muodostamaan taustaa vasten. Tästä näkökulmasta katsoen taloustiede oli korostetusti empiirinen ja induktiivinen tiede.

Gyllingin pro gradu -tutkielma valmistui vuonna 1903 aiheesta Maanviljelystyöväen taloudellisista oloista Ikaalisen pitäjässä vuonna 1902. Gylling tutustui pro gradua tehdessään ensimmäistä kertaa toden teolla maaseudun sosiaaliseen tilanteeseen. Ikaalisissa epäkohdat olivat pienempiä kuin maassa keskimäärin, mutta viimeistään tämän tutkimuksen aikana hän toden teolla kiinnitti huomionsa maaseudun yhteiskunnallisiin ongelmiin. Samalla hän teki ensimmäistä kertaa vakavaa tilastollista ja yhteiskunnallista tutkimustyötä. Gyllingin pro gradu oli empiirinen ja tilastollinen tutkimus, missä yhteys ajan sosiaalipolitiikkaan oli selvä.

Kansainvälisessä työväenliikkeessä syntynyt debatti kautskylaisuuden ja revisionismin välillä konkretisoitui erityisesti maatalouden kehitykseen, joka ei näyttänyt soveltuvan marxilaiseen yleiskuvaan. Vuonna 1906 Gylling horjui maantalouden kehityksen tulkinnassaan kautskylaisuuden ja revisionismin välillä, mutta päätyi sitten varovaisesti edellisen kannalle. Samalla Gylling osal- 
taan vaikutti siihen, että Suomen sosialidemokraatit eivät ainakaan teoreettisella tasolla omaksuneet revisionistisia kantoja edes maatalouspolitiikassa, vaan pitivät lopullisena päämääränä sosialistista maataloutta. Tätä asiaa ei ole aiemmassa tutkimuksessa juuri huomioitu. Lyhyen aikavälin tavoitteissaan puolue oli tosin valmis myös tukemaan yksityistä maanomistusta.

Gylling julkaisi vuonna 1909 väitöskirjansa aiheesta Suomen torpparilaitoksen kehityksen pääpiirteet Ruotsinvallan aikana tarkoituksenaan ongelman valottaminen historiallisesta näkökulmasta. Teos on empiriaan ja tilastoihin pohjautuva, eikä se ei sisällä mitään varsinaista teoreettista viitekehystä. Gyllingin tutkimusten toteutustapa soveltuu hyvin kansantaloustieteen historiallisen koulukunnan tavoitteisiin, joissa historiallinen näkökulma yhdistyy pyrkimykseen ratkaista oman ajan sosiaalisia ongelmia. Toisaalta myös marxilaisessa tutkimusotteessa historiallisen kehityksen analysointi on tärkeää.

Väitöskirjassaan Gylling kartoitti torpparilaitoksen kehityksen historiallista taustaa ennen kaikkea taloushistoriallisesta näkökulmasta. Gylling korostaa paikoin varsin marxilaisesti väestöryhmien välisiä ristiriitoja ja tuotantovälineiden omistussuhteita, joskin ilman selkeää yhteyttä teoriaan. Hän halusi väitöskirjallaan tuoda lisävalaistusta ilmiön historialliseen kehitykseen ja syihin. Väitöskirja jäi kuitenkin varsin vähällä huomiolle ja yritys tuoda uusi näkökulma keskusteluun torpparilaitoksesta ei onnistunut. Voi olla, että poliittiset ryhmät olivat lyöneet kantansa lukkoon niin tiiviisti, ettei uudenlaiselle tarkastelulle ollut enää tilaa.

Gyllingin tutkijanote oli vahvasti empiirinen ja tilastotietoon nojautuva. Tässä on selvä yhteys Bernsteinin revisionistiseen ajatteluun. Empiirinen ote näkyy esimerkiksi lukuisissa väestötieteellisissä artikkeleissa, joita Gylling kirjoitti 1910-luvulla. Koska Gylling oli tilastotietoon vahvasti nojaava empiristi, hän vältti maatalouden kehityksen lopullisen suunnan määrittelemistä teorian kautta. Tämä näkyi myös käytännössä siinä, että SDP:n maatalouspoliittinen linja oli varsin mukautuva ja pragmaattinen, välillä sekavakin. Valtiopäivien työskentelyssä sitä ei kuitenkaan voi pitää kovin yhteistyöhakuisena. 
Gyllingin käyttämien käsitteiden kautta voidaan myös analysoida hänen ajatteluaan ja siinä tapahtuneita muutoksia. Gylling käytti maatalouden kysymyksiin liittyen muun muassa seuraavia käsitteitä: "maanomistajat", "maanvuokraajat", "torpparit", "(maalais)köyhälistö", "tilaton väestö", "viljelyspakko", ja "pienviljelys". Hänen käyttämistään käsitteistä yleisempään yhteiskuntateoreettiseen ajatteluun liittyvät muun muassa seuraavat: "kapitalismi", "porvaristo", luokka", "kansa", "luokkaviha" ja "luokkataistelu". Gyllingin kiinnostus historian kehitykseen näkyy siinä, että erityisesti käsitettä "feodalismi" hän analysoi erityisen perusteellisesti. Hänen käsityksekseen muodosti näkemys, jonka mukaan feodalismia ei Suomessa ollut esiintynyt tyypillisessä muodossa, mutta se oli torpparilaitoksen kautta saanut täällä oman muotonsa. Gyllingin väitöskirjassaan käyttämät käsitteet olivat kuitenkin varsin yleisluontoisia, kuten esimerkiksi "yhteiskuntataloudelliset voimat", "väestöluokka" tai "tuotantotapa". Näitä käsitteitä käyttivät myös porvarilliset tutkijat.

Marxilaiset teoreetikot ja tutkijat käyttivät näitä käsitteitä omissa kirjoituksissaan. Toisaalta myös monet muut yhteiskuntatieteen suuret nimet - kuten Max Weber tai Werner Sombart - käyttivät esimerkiksi käsitteitä "luokka" tai "kapitalismi". Vastaavia käsitteitä käyttivät myös monet muut suomalaiset tutkijat, joista jotkut toimivat aktiivisesti porvarillisissa puolueissa. Kuitenkin käsitteet "luokkataistelu" tai peräti "luokkaviha" edustavat selvästi jyrkkää marxilaista näkemystä yhteiskunnan kehityksestä luokkien välisten vastakohtaisuuksien kautta. Tätä käsitystä täydentävät ne kirjoitukset, joissa Gylling käytti käsitteitä "maanomistajat", "porvaristo" tai "omistava luokka". Ainakin vuodesta 1906 lähtien hän liitti käsitteet marxilaiseen historianfilosofiaan ja yleiseen yhteiskuntateoreettiseen kehitykseen. Gyllingin puolueopistolla 1910-luvun alussa pitämien luentojen pohjana on vahvasti marxilainen käsitteistö ja historianfilosofia.

Gyllingin maatalouden kehitystä koskevan ajattelun keskiöön tuli vähitellen yhä selvemmin marxilainen historianfilosofia ja sen antama käsitys, jonka mukaan kapitalismi kehittyy tiedettyjen lainalaisuuksien myötä ja mahdollista sitä kautta sosialismin syn- 
tymisen. Tämä näkyy selvästi esimerkiksi hänen puolueopistossa pitämistään luennoista.

Kuten aiemmissa Gyllingin tutkijankuvasta kirjoitetuissa artikkeleissa on huomioitu, hän oli ennen kaikkea yhteiskuntaa tutkiva tilastotieteilijä, joka kiinnitti paljon huomiota myös historialliseen kehitykseen. Hän perusteli historiastakin käsin näkemyksiään suomalaisen yhteiskunnan tilasta ja siitä, millaisella politiikalla maaseudun ongelmia tulisi ratkaista. Tämä osoittaa sen, että yhteiskunnallisia ilmiöitä ja ongelmia oli hänestä tärkeätä tarkastella myös menneisyydestä käsin. Välillä Gylling käytti historiaa poliittisten argumenttiensa tai tavoitteidensa tukena tavalla, jota nykyään kutsuttaisiin historiapolitiikaksi. Tätä yhteyttä aiemmassa Gyllingiä koskevassa tutkimuksessa ei ole kovin selkeästi tuotu esille.

Kuitenkin Gylling erotteli tutkijan ja poliitikon roolit toisistaan kirjoittaessaan erilaisia tekstejä tai toimiessaan valtiopäivillä. Tutkijana hän kirjoitti ennen kaikkea muille tutkijoille. Kun hän kirjoitti maaseudun sosiaalisista oloista tai yhteiskunnallisista ongelmista, tutkimustieto toimi poliittisen argumentaation tukena. Näin tapahtui myös monissa valtiopäivillä käydyissä keskusteluissa, joissa hän usein vetosi maaseudun olojen historialliseen kehitykseen ja tilastollisiin tietoihin. Gyllingille tilasto oli kaiken kaikkiaan erittäin tärkeä työkalu, jonka avulla on mahdollista saada tietoa yhteiskunnallisista ilmiöistä. Tätä tietoa voitaisiin sitten käyttää erilaisten ongelmien ratkaisemisessa ja paremman yhteiskunnan suunnittelussa.

Tieteellisestä taustastaan huolimatta poliitikko Gylling käytti esimerkiksi Työmiehen kirjoituksissaan välillä varsin voimakasta retoriikkaa ja hyökkäävää sävyä, joissa hän usein vetosi suoraan maanvuokraajaväestön ja muun tilattoman väestön tukeen. Tämä liittyi usein eduskuntavaaleja edeltäneisiin vaalitaisteluihin, joiden aikana poliittisen keskustelun sävy kärjistyi kautta linjan. Toisaalta välillä sosialidemokraattisen ja porvarillisten puolueiden väliset ristiriidat kärjistyivät, jolloin myös argumentointi ja siinä käytetty retoriikka koventuivat. 
Eduskunnassa käytyjen keskustelujen sävy kärjistyi erityisesti vuonna 1917 samalla kuin yhteiskunnallinen tilanne muuttui yhä epävakaammaksi. Käydyissä keskusteluissa Gylling suorastaan pelotteli porvarillisia edustajia lähestyvällä maanvuokraajien ja työväestön vallankumouksella. Samaan aikaan hän kuitenkin puolueen sisällä toimi aktiivisesti aseellista toimintaa vastaan ja yritti löytää neuvotteluyhteyttä maalaisliiton kanssa. Gyllingin perimmäinen tarkoitus olikin ilmeisesti painostaa porvarilliset puolueet hyväksymään torpparivapautus, jolloin joukkojen vallankumouksellinen paine vähentyisi. Näin ei tunnetusti tapahtunut, vaan alkoi sisällissota.

Punaisten tappioon päättyneen sisällissodan jälkeen Gylling kirjoitti muistion, jossa hän kertoi käsityksiään tapahtumien syistä. Hän nostaa esille sen, ettei puolue saanut aikaan näitä suuria maalaisryhmiä koskevia uudistuksia. Puolue luopui viljelyspakosta, joka kohtasi suurta vastarintaa porvarillisten puolueiden taholta. Hänen mukaansa muita puolueita ei saatu taipumaan myöskään oikean torpparireformin taakse. Sen syntymisen esti lopulta myös sotatila, jonka aikana eduskuntaa ei kutsuttu koolle. Gylling arvioi, että näiden epäonnistumisten takia radikaalin maalaisväestön kumouksellisuus kasvoi entisestään. Olisiko sisällissota voitu estää, jos valtiopäivät olisi saanut aikaan enemmän maanvuokraajien ja maatyöväestön asemaa parantavia uudistuksia? Tähän kysymykseen ei voi antaa varmaa vastausta.

Gyllingiä voi pitää tieteelliseen tutkimukseen tukeutuvana, mutta pragmaattisena marxilaisena, joka näkyi SDP:n maatalouspoliittisissa linjauksissa ennen kaikkea joustavuutena. Vaikka SDP:n pitkän aikavälin tavoitteena oli marxilaisesti sosialismin toteuttaminen maataloudessakin, niin puolue oli lyhyellä aikavälillä valmis vahvistamaan yksityiseen omistusoikeuteen perustuvaa maanviljelystä. Keskeistä tässä oli se, että maanvuokraajat saivat hyvän korvauksen vuokratilallaan tekemästään työstä.

Kaiken kaikkiaan voidaan sanoa, että Edvard Gyllingin merkitys SDP:n maatalouspolitiikalle vuosina 1905-1918 oli suuri, vaikkei hän sitä yksin muotoillutkaan. Gylling oli puolueen maatalouspolitiikan johtava asiantuntija ja linjanvetäjä erityisesti siksi, 
että hänessä yhdistyi vahva tutkimusosaaminen käytännölliseen poliittiseen toimintaan. Tämän takia hän pystyi haastamaan porvarillisten puolueiden johtavat asiantuntijat, kuten esimerkiksi vanhasuomalaisten J. R. Danielson-Kalmerin ja Hannes Gebhardin. Gyllingin maatalouspoliittisissa näkemyksissä ja toiminnassa yhdistyi pyrkimys yhteiskunnan taloudelliseen tehokkuuteen ja halu sosiaalisen oikeudenmukaisuuteen. Marxilainen teoria yhteiskuntakehityksestä oli rinnakkain yhteiskuntapoliittisen intressin kanssa. Suurlakon jälkeisinä vuosina Gylling oli ennen kaikkea tutkija, mutta valtiopäivätyöskentelyn ja maanvuokraajien liikkeen nousun myötä hänestä tuli yhä selvemmin poliitikko. 


\section{Summary}

This is a study of Edvard Gylling's (1881-1938) thought and activities regarding agricultural policy in the period between the general strike of 1905 and the Finnish Civil War in 1918. During that time, Gylling was the agricultural policy expert of the Social Democratic Party (SDP) of Finland and therefore had an important impact on the party's policies as well as throughout Finnish society in general. Because he was also a social scientist, an analysis of his own research makes it possible to create a complete picture of his agricultural policy guidelines and solutions.

The strongest unifying factor in Gylling's research and his political activity is agriculture, specifically the issue of improving the position of tenant farmers and the landless population. His significant knowledge and expertise were used in many ways in parliamentary and committee work as well as in the tenant farmer movement. Gylling was also interested in population issues, and this study deals with these topics as far as they relate to agriculture and rural conditions.

In my research I address the following questions for the selected period. The main question is the following:

1. What is the impact of Edvard Gylling's agricultural policy and his activities within the Social Democratic Party and throughout society in general?

The following sub-questions contribute to answering the main question. These additional questions are essentially supportive.

2. On which scientific and political statements did Gylling base his agricultural policy?

3. How did Gylling's scientific and agricultural political opinions change in different situations and over time?

4. How did Gylling use research information to support his agricultural policy in action? 
Previous research has also identified Edward Gylling as one of the key experts in shaping the agricultural policy of the Social Democratic Party. This study supports and clarifies that image. In the period from 1905 to 1918, Gylling's impact on the SDP's agricultural policy was substantial, even though he was not its only developer. Gylling was the leading expert of the party's agricultural policy, particularly because he combined strong research competence with practical political activity. The party's agricultural policy was also affected by the other party leaders and experts, particularly Oscar Tokai and Sulo Wuolijoki, who both had familiarity with agricultural issues. Gylling was, at first, primarily a scientist, but eventually politics began to take up more of his time. He was re-elected to the parliament several times, and he eventually became one of the leading politicians in the Social Democratic Party.

Within the international labour movement, a debate existed over Kautskyism and revisionism. This debate made the development of agriculture particularly relevant, because it did not appear to be compatible with Marxist theory. In 1906, Gylling considered his own interpretation of Kautskyism and revisionism within the context of Finland's economic development, and eventually ended up supporting the former approach. At that time, partly due to his influence, the SDP did not, at least on a theoretical level, embrace revisionist positions as part of the party's agricultural policy. Instead, the party set the ultimate goal of establishing a socialist agriculture, a fact which previous research has overlooked.

After the general strike, Gylling became the Social Democrats' leading agricultural policy expert. His expertise was widely used in parliamentary work, national crofters' meetings and working groups of the party. Under his influence, in 1906 the SDP made forced cultivation the key requirement in agricultural policy. Forced cultivation meant that when landowners chose not to cultivate their arable land, they had to submit it to a tenant farmer for cultivation. This allowed landless people to become settlers and gave smallholders the opportunity to expand their crops. Forced cultivation permitted a way to meet the demand for agriculture 
without increasing the number of landowners, but its implementation, on the other hand, would have meant an increase in smallholders.

Gylling completed his master's thesis in 1903 under the title "The economic conditions of agricultural workers in the Ikaalinen parish in 1902”. During his research, Gylling acquainted himself in earnest with the social situation in rural areas for the first time. It was at this time that he made his first serious statistical and social research on the subject. In 1909, his dissertation was published, under the title "The main developmental features of the Finnish crofter's position during the Swedish regime", with the intention of exposing the problem from a historical perspective. The study is based on empirical and statistical data, and it contains no actual theoretical framework. Its methodology is well-suited to the objectives of the historical school of political economics, in which the aim is to combine solutions for the social problems of the current era with a historical perspective. In Marxist research approaches, on the other hand, the analysis of the historical development is valued. With his dissertation, Gylling wanted to shine a light on the issue's historical development as well as the causes of it as a phenomenon. However, the dissertation received little attention, so the attempt to bring a new perspective to the debate over crofting and tenant farming was not successful. It may be that the political parties had already staked out their positions, so there was no space for fresh scrutiny.

Gylling continued to base his methods on strong empirical and statistical data, an approach had a connection to the revisionist thinking of Eduard Bernstein. This empirical focus emerges, for example, in a number of scientific articles on demography Gylling wrote in the 1910s. Because Gylling was an empiricist who relied strongly on statistical data, he avoided a final definition of agricultural development based on any single theory. In practice, this approach influenced the Social Democratic Party's agricultural policy, which became adaptable and pragmatic. In parliament work, this approach was not, however, considered to be very cooperative. 
In his thought on agricultural development, Gylling gradually adopted the history of Marxist philosophy and the notion that capitalism develops through certain patterns and allows the emergence of socialism. This conclusion can be clearly seen, for example, in his lectures at the party institute. Gylling can be considered to have been a supporter of science, as well as a pragmatic Marxist, whose influence on the development of the Social Democratic Party's agricultural policy was seen, above all, in its flexibility. Although the SDP's long-term objective was to implement Marxist socialism in agriculture, the party was, in the short term, ready to strengthen the rights of private ownership in the cultivation of land. The key to this was the fact that the tenant farmers' compensation for the work would be satisfactory.

As has been stated in previous articles on Gylling's career as a researcher, he was, above all, a social demography statistician who drew a lot of attention to historical development. He used historical arguments to explain his views on Finnish society and on which policy could solve specific rural problems. Sometimes Gylling used history to support his political arguments or objectives in a way today would be called historical politics. In previous research on Gylling, this connection has not been sufficiently taken into account.

Though Gylling, in his writing and work in parliament, did distinguish between his roles as a researcher and a politician, his work in both areas supported each other. As a researcher, he wrote primarily for other researchers. When he wrote about the social circumstances and problems in rural areas, research data supported his political argumentation. This also occurred in many debates in the parliament, where he often relied on historical rural development and statistical data. For Gylling, statistics were a vital tool for obtaining information about society. This information could be applied to a variety of problems as well as to design a better society.

In 1909, the Tenancy Act froze tenancies up to 1916. During this time, the aim was to solve the problem once and for all. The new tenancy law was a compromise in which no political party 
had been fully satisfied. For the right-wing, it represented an oppression of the principle of eternal ownership; for the left-wing, it allowed an already poor situation to continue. The centre parties also thought the Act would be harmful. Gylling saw the new land lease law as a first step to accomplishing more fundamental changes in the near future.

Under Gylling's leadership, the SDP stood down on its demand for forced cultivation within five years, because it turned out to be an unrealistic requirement. Even the new alignment was not a socialist one. Starting in 1911, the party's intention was to turn tenant farmers into owners, even if, in principle, it still did not accept private land ownership. It believed, however, that such a change would assure the crofter's work effort and property as much as it is possible in a capitalist society. After this, the SDP appealed to have the tenant farmer's actual right of occupancy respected, and on the basis of their work also their right to redeem the farm with a good contract.

The SDP and bourgeois parties subsequently agreed on the need for emancipation of the crofters, but they disagreed on the means. The parties were unable, however, to resolve the issue before the outbreak of the First World War. Similarly, no progress was made on work to improve the status of the rest of the landless population. The discussions in parliament came to a head in 1917, at the same time that the social situation was becoming increasingly unstable. In debates, Gylling actually warned the bourgeois representatives of impending revolution by the tenant farmers and the working class. At the same time, he worked actively within the party against armed action and tried to initiate negotiations with the Agrarian Party. Gylling's ultimate purpose was apparently to pressure the non-socialist parties to accept the liberation of the crofters by political means, so that the pressure of the revolutionary forces would subside. As is already known, these efforts failed, and civil war broke out in January 1918. In July 1918, after the end of the war, the rump parliament approved the Crofters Act, which gave tenant farmers the right to redeem the rented farms. 
In conclusion, Gylling's activities united society's aspiration for economic efficiency with the desire for social justice. The Marxist theory of social development ran parallel to sociopolitical interests. After the general strike, Gylling was primarily a scientist, but he gradually became more clearly a politician. 


\title{
Lähteet
}

\author{
Arkistolähteet
}

Helsingin Yliopiston Keskusarkisto (HYKA)

Kanslerinviraston vihkot

Konsistorin pöytäkirjat

Helsingin Yliopiston Kirjasto (HYK)

Savo-Karjalaisen osakunnan pöytäkirjat

Jyväskylän Maakunta-arkisto (JMA)

Jyväskylän Lyseon kokoelma (JLK)

Kansallisarkisto (KA)

Arvo Ylärakkolan kokoelma (AYK)

Edvard Gyllingin kokoelma (EGK)

Nuorsuomalaisen puolueen arkisto

Suomalaisen puolueen arkisto

Kansan Arkisto (KansA)

Kokoelma Gylling-seminaarista (KGS)

Suomalaisen Kirjallisuuden Seura (SKS)

Heikki Ojansuun kirjekokoelma

Työväen Arkisto (TA)

Puolueopiston aineisto 1910-1913

Turun läänin Pohjoisen sosialidemokraattisen piirin aineistoa Ylioppilaiden Sosialidemokraattisen Yhdistyksen (YSY) pöytäkirjat

SDP:n eduskuntaryhmän pöytäkirjat 1907-1914

SDP:n puolueneuvoston toimintakertomukset

SDP:n puolueneuvoston pöytäkirjat 1917 


\section{Painetut alkuperäislähteet}

Edvard Gyllingin tutkimukset ja kirjoitukset

1904 A Nykyisestä siirtolaisuudestamme. Satakunta 8.11.1904.

1904 B Nykyisen siirtolaisuutemme syistä. Satakunta 19.11.1904.

1905 A Tarkotuksemme (yhdessä Otto Ville Kuusisen, Yrjö Sirolan ja Sulo Wuolijoen kanssa). Sosialistinen Aikakauslehti, näytenumero 1/1905.

1905 B Maatalouskysymys puolueohjelmassamme, Sosialistinen Aikakauslehti , näytenumero 1/1905.

1905 C Kapitalistisesta tuotannon järjestyksestä nykyaikana. Yhteiskuntataloudellinen Aikakauskirja n:o 3/1905.

1905 D Perintötorpista. Satakunta 26.8.1905.

1906 A Väestö-, invaliditeetti- ja tulosuhteet Tuusulan, Humppilan, Kymin, Räisälän ja Vihannin kunnissa vuonna 1903 II, taulukkoosa. Invaliditeettivakuutuskomitean julkaisu III. Helsinki 1906.

1906 B Sosialismista ja maatalouskysymyksestä, Kansan kalenteri II (julkaistiin 1907), 1906.

1906 C Siirtolaisuutemme ja tilaton väestö, Sosialistinen Aikakauslehti, näytenumero 3/1906.

1906 D Torpparit ja työväenliike, Sosialistinen Aikakauslehti 4/1906.

1906 E Uusi vaalilakiehdotus, Sosialistinen Aikakauslehti 6/1906.

1906 F Torppariolojen uudistamisen johdosta, Sosialistinen Aikakauslehti 7/1906.

1906 G Torpparikokous Tampereella, Sosialistinen Aikakauslehti 8/1906.

1906 H Viljelyspakko ja tilattoman väestön asema. Sosialistinen Aikakauslehti 17-18/1906.

1906 I Sosialidemokratia ja suomettarelaiset, Sosialistinen Aikakauslehti 20-21/1906.

1907 A Maanviljelystyöväen taloudellisista oloista Ikaalisten pitäjässä v.1902. Taloustieteellisiä tutkimuksia III. Helsinki 1907.

1907 B Väestö-, invaliditeetti- ja tulosuhteet Tuusulan, Humppilan, Kymin, Räisälän ja Vihannin kunnissa vuonna 1903 I, teksti-osa. Invaliditeettivakuutuskomitean julkaisu II. Helsinki 1907. 
1907 C Maalaistyöväki ja sosialismi Suomessa. Työmies 27.2.1907).

1907 D Pakkoluovutuksen ja viljelyspakon entinen ja nykyinen asema meillä. Sosialistinen Aikakauslehti 26/1907.

1907 E Työhön kaikki!, Sosialistinen Aikakauslehti 30/1907.

1907 F Uutta maalaisolojamme valaisevaa tilastoa, Sosialistinen Aikakauslehti 30/1907.

1907 G Päättyneet valtiopäivät ja maakysymys, Sosialistinen Aikakauslehti 34-35/1907.

1907 H Katsaus viime eduskuntavaaleihin, Työväen Kalenteri I/1908, 1907.

1907 I Suomettarelaiset vastustamassa viljelyspakkoa. Työmies 22.2. 1907.

1908 A Torpparihäätöjen estäminen. Sosialistinen Aikakauslehti 37/1908.

1908 B Suomen torpparien toinen edustajakokous Tampereella. Sosialistinen Aikakauslehti 37/1908.

1908 C Hiukan lampuotitilojen, torppien ja mäkitupa-alueitten vuokramaksusta, Sosialistinen Aikakauslehti 40/1908.

1908 D Torpparit, tilattomat ja köyhälistöpuolue, Sosialistinen Aikakauslehti 42/1908.

1908 E Eduskunnan hyväksymä asetus maanvuokrasta, Sosialistinen Aikakauslehti 44-45/1908.

1908 F Katsauksia Suomen taloudelliseen kehitykseen. Työväen Kalenteri II (julkaistu 1909), 1908.

1908 G Suomettarelaisten maatalousohjelmasta. Sosialidemokraatti 14.5.1908.

1909 A Suomen torpparilaitoksen kehityksen pääpiirteet Ruotsinvallan aikana. Taloustieteellisiä Tutkimuksia IX 1909. Helsinki 1909.

1909 B Hufvuddragen af torpareklassens utveckling i Finland. Folktribunen 12/1909.

1909 C Katsaus torpparilaitoksen kehitykseen Suomessa. Työväen Kalenteri III/1910, 1909.

1909 D Hiukan vanhemmasta väestötilastostamme. Yhteiskuntataloudellinen Aikakauskirja, 2/1909.

1909 E Suomen torpparilaitoksen kehityksen pääpiirteet. Työmies 2.6.1909. 
1909 F Maaküsimus Soomes. Teoksessa Soome 1909. Kirieldused Soome oludest. Toim. M. Martna. Tallinna 1909.

1910 A Katsaus Suomen väkilukuun 1749-1908. Työväen Kalenteri IV/1911, 1910.

1910 B Milloin talolliset saivat oikeuden torpparin verottamiseen. Uuden ajan kynnyksellä, Suomen työväen joulualbumi XIII, 1910.

1910 C Maanvuokraolot. Yhteiskunnallinen Käsikirja, 1910.

1910 D Eräitä uusia tilastotietoja Suomen siirtolaisuudesta. Yhteiskuntataloudellinen Aikakauskirja, 2/1910.

1910 E Vielä eräitä vaalitilaston opetuksia. Työmies 1.7.1910.

1911 A Statistiska bidrag till svenska folkstammens historia i Finland. Helsingfors 1911.

1911 B Väestö. Sata vuotta Suomen sivistyselämää. Kansanvalistusseuran toimituksia 158. Helsinki 1911.

1911 C Väentiheys v.1749 ja väenlisäys vuosina 1749-1908. Suomen Kartasto 24-28, VI. Helsinki 1911.

1911 D Väestön ryhmitys syntymäpaikan mukaan ja sisäinen muuttoliike Suomessa. Suomen Kartasto 24-28, VI. Helsinki 1911.

1912 Lausunto teoksesta Mannelin, Karl, Finlands smöexport. Yhteiskuntataloudellinen Aikakauskirja, 2/1912.

1913 Muutamia tilastotietoja Helsingistä. Työväen Kalenteri VII. 1913.

1915 A Syntyneisyydestä ja väestön lisääntymisestä Helsingissä. Helsinki 1915.

1915 B Syntyneisyys ja lastenkuolleisuus Suomessa viime vuosikymmeninä. Yhteiskuntataloudellinen Aikakauskirja, 2/1915.

1915 C Torpparikysymyksen tila. Työmies 22.1.1915.

1915 D Torppariolojen lopullinen järjestely. Maanvuokrakomitean ehdotuksen pääpiirteet. Työmies 22.1.1915.

1915 E Ajaako maanvuokrakomitea torpparien asiaa. Työmies 28.1. 1915.

1915 F Torpparikysymyksestä vieläkin. Työmies 4.3.1915.

1915 G Torpparivapautuksesta. Työmies 17.3.1915.

1915 H Tarvitseeko torppari metsä ja laidunmaata? Työmies 23.3.1915. 
1915 I Torpparien viljelysmaat. Onko niitä vähennettävä? Työmies 10.4.1915 ja 12.4.1915.

1915 J Kurjat verotusolomme. Työmies 17.6.1915.

1915 K Rajahinnatko poistettava? Työmies 20.7.1915.

1915 L Osuuskassojen Keskuslainarahaston uusi osakemerkintä. Työmies 29.7.1915.

1915 M Voipula ja elintarvikekysymyksen järjestely. Työmies 15.10. 1915.

1916 A Numerojen yhteiskuntafilosofiaa. Uuden ajan kynnyksellä XIX. Suomen työväen joulualpumi. Helsinki 1916.

1916 B Torpparien oikeuksista väittelyä. Työmies 5.3.1916.

1916 C Eduskunnan päätösten rikkominen. Kapitalististen voittoetujen lisäämiseksi osuuskassaliikkeen turvissa. Työmies 19.3.1916.

1916 D Porvarillisten puolueiden vaaliohjelmasta torppariasiassa. Työmies 20.4., 28.4. ja 12.5.1916.

1917 A Suomi (väestö ja asutus). Teoksessa Tietosanakirja 9. Toim. Wichmann, Yrjö et al. Helsinki 1917.

1917 B Tilastotiede (yhdessä Jaakko Forsmanin kanssa). Teoksessa Tietosanakirja 9. Toim. Wechmann, Yrjö et al. Helsinki 1917.

1917 C Tilaton väestö. Teoksessa Tietosanakirja 9. Toim. Wechmann, Yrjö et al. Helsinki 1917.

1917 D Nälkävuodet. Puolivuosisataismuisto. Työväen Kalenteri XI (painettu 1918). 1917.

1917 E Torpparihäädöt. Onko äskeinen manifesti tehnyt ne mahdollisiksi? Työmies 11.4.1917.

1917 F Porvarillinen valtiontalous. Verotulojen uudistus välttämätön. Työmies 16.9.1917.

1917 G Vuoden 1917 rahasääntö. Valiokunnan ehdotus menosäännöksi. Työmies 22.9.1917.

$1917 \mathrm{H}$ Verotusolojen uudistuksen puolesta. Valtiovaroja yhteiskunnallisiin uudistuksiin. Työmies 1.10.1917.

1917 I Alustalaiset heti vapaiksi. Työmies 7.11.1917. 


\section{Muiden kirjoitukset}

Bernstein, Eduard, Enemmistövaalit vai suhteellinen vaalitapa, Sosialistinen Aikakauslehti 1906.

Bernstein, Eduard, Sosialismin edellytykset ja sosialismin tehtävät. Näköispainos Juva 1982 (1910).

Danielson-Kalmari, J. R., Edistyksen jarruttaminen. Uusi Suometar 25.11.1906 (A).

Danielson-Kalmari, J. R., Meikäläinen sosialidemokratia I, Uusi Suometar 2.12.1906 (B).

Danielson-Kalmari, J. R., Meikäläinen sosialidemokratia II. Uusi Suometar 4.12.1906 (C).

Danielson-Kalmari, J. R., Meikäläinen sosialidemokratia II, jatko-osa. Uusi Suometar 6.12.1906 (D).

Danielson-Kalmari, J. R., Sosialistiväittelyä. Uusi Suometar 29.12.1906 (E).

Danielson-Kalmari, J. R., Sosialistien viljelyspakko. Uusi Suometar 14.2. 1907 (A).

Danielson-Kalmari, J. R., Sosialistien viljelyspakko II. Uusi Suometar 16.2.1907 (B).

Danielson-Kalmari, J. R., Sosialistien viljelyspakko III, Uusi Suometar 26.2.1907 (C).

Danielson-Kalmari, J. R., Herra Sulo Wuolijoki yrittää vielä kerran. Uusi Suometar 12.3.1907 (D).

Forsman, Jaakko, Mistä syystä sosialismi levisi Suomen maalaisväestön keskuuteen. Helsinki 1912.

Gebhard, Hannes, Maatalousoppi ja maanviljelyksen kansantaloustiede tutkimus- ja opetusaineina. Valvoja 1901.

Gebhard, Hannes, Yhteiskuntataloudelliset olot Suomen maalaiskunnissa. Teoksessa Oma Maa 4. Toim. Palmén, E. G. et al., Porvoo 1909.

Gebhard, Hannes, Maanviljelysväestö. Sen suhde muihin elinkeinoryhmiin ja sen yhteiskunnallinen kokoonpano Suomen maalaiskunnissa. Tilattoman väestön alakomitean tilastollinen tutkimus yhteiskuntataloudellisista oloista Suomen maalaiskunnissa 1901. Helsinki 1913.

George, Henry, Edistys ja köyhyys. Suom. Järnefelt, Arvid. Helsinki 1906(1879). 
Kallio, Topi, Palvelijapolitiikasta Suomessa 18. vuosisadalla. Taloustieteellisiä Tutkimuksia XI. Helsinki 1913.

Kautsky, Karl, The Agrarian Question. In two volumes. Translated by Pete Burgess. London 1988 (1899).

Kautsky, Karl, Erfurtin ohjelma. 3. suomenkielinen painos. Helsinki 1974(1891).

Kautsky, Karl, Enemmistövaalit vai suhteellinen vaalitapa, Sosialistinen Aikakauslehti 1906.

Kilpi, O.K., Suomen siirtolaisuus ja 19.vuosisadan kansantalous. Taloustieteellisiä tutkimuksia XXII. Helsinki 1917.

Kovero, Martti, Valtion uutisasutus Ruotsin-Suomessa jälkeen Isonvihan. Asutuspoliittinen tutkimus. Helsinki 1909

Kuusi, Eino, Työväenkysymys. Teoksessa Oma Maa 5. Toim. Palmén, E.G. et al., Porvoo 1910.

Marx, Karl, Das Kapital. Kritik der politischen Ökonomie. Hamburg 1867. Julkaistu sarjassa Marx, Karl - Engels, Friedrich, Gesamtausgabe. Zweite Abteilung. ”Das Kapital" und vorarbeiten. Band 5. Berlin 1983.

Marx, Karl - Engels, Friedrich, Feuerbach. Materialistisen ja idealistisen katsantokannan vastakkaisuus (kirjoitettu 1845-46).Teoksessa Marx, Karl - Engels, Friedrich, Valitut teokset 1. Moskova 1970.

Warén, Aksel, Torpparioloista Suomessa. Suomalaisen Kirjallisuuden Seuran toimituksia 89. Helsinki 1898.

Yrjö-Koskinen, Yrjö Sakari, Johtavat aatteet ihmiskunnan historiassa. III painos. Helsinki 1960 (1900)

Yrjö-Koskinen, Yrjö Sakari, Nuijasota. Sen syyt ja tapaukset. 2. uudistettu painos. Helsinki 1877.

Yrjö-Koskinen, Yrjö-Sakari, Suomen kansan historia. 3.painos. Historiallinen Kirjasto II. Helsinki 1933 (1881).

Muut painetut alkuperäislähteet

Hodgson, John H., Edvard Gylling ja Otto Ville Kuusinen asiakirjojen valossa 1918-1929. Helsinki 1974. 
Jyväskylän lyseon oppilasmatrikkeli. Teoksessa Jyväskylän lyseo 18581983. Toim. Mikkola, Eero. Jyväskylä 1983.

Kansantaloudellisen Yhdistyksen jäsenluettelo, vuosi 1903 ja esitelmäluettelo vuosilta 1904-1914. Molemmat painettuna teoksessa Harmaja Leo, Kansantaloudellinen Yhdistys 1884-1934. Helsinki 1934.

Karl H.Wiiks Dagbok från storstrejken till upproret 1917-1918. Utgiven av Sten Lindman. Åbo 1978.

Kertomus SDP:n puoluetoimikunnan toiminnasta 26.8.1906 -15.7.1909. Helsinki 1909.

Kertomus SDP:n puoluetoimikunnan toiminnasta 13.9.1909-15.7.1911. Kotka 1911.

Maalaisliiton maatalousohjelma. Painettuna Borg Olavi, Suomen puolueet ja puolueohjelmat 1880-1964. Porvoo 1965 (A).

Maanvuokraajien toisen yleisen edustajakokouksen pöytäkirja. Helsinki 1908.

Maanvuokraajien neljännen yleisen edustajakokouksen pöytäkirja. Tampere 1911.

Maanvuokraajien viidennen yleisen edustajakokouksen pöytäkirja. Tampere 1913.

Maanvuokrakomitean mietinnöt

-Komiteamietintö 1/1913

-Komiteamietintö 4/1914

Ruotsalaisen kansanpuolueen maatalousohjelma. Painettuna Borg Olavi, Suomen puolueet ja puolueohjelmat 1880-1964. Porvoo 1965 (A).

Selonteko Keisarillisen Aleksanterin -yliopiston opettajain toiminnasta lukuvuonna 1910-1911. Helsinki 1911.

Selonteko Keisarillisen Aleksanterin -yliopiston opettajain toiminnasta lukuvuonna 1911-1912. Helsinki 1912.

Selonteko keisarillisen Aleksanterin -yliopiston opettajain toiminnasta lukuvuonna 1912-1913. Helsinki 1913.

Selonteko keisarillisen Aleksanterin -yliopiston opettajain toiminnasta lukuvuonna 1913-1914. Helsinki 1914.

Suomalaisen puolueen maatalousohjelma. Painettuna Borg Olavi, Suomen puolueet ja puolueohjelmat 1880-1964. Porvoo 1965 (A). 
Suomen sosialidemokraattisen puolueen maatalousohjelma. Painettuna Borg Olavi, Suomen puolueet ja puolueohjelmat 1880-1964. Porvoo 1965 (A).

Suomen sosialidemokraattisen puolueen viidennen edustajakokouksen pöytäkirja. Ei painopaikkaa ja -vuotta. (SDP:n V PK).

Suomen Sosialidemokraattisen Puolueen kuudennen edustajakokouksen pöytäkirja. Kotka 1909 (SDP:n VI PK).

Suomen Sosialidemokraattisen Puolueen seitsemännen edustajakokouksen pöytäkirja. Helsinki, ei painovuotta (SDP:n VII PK).

Torpparien ensimmäisen yleisen edustajakokouksen pöytäkirja. Helsinki 1906.

Valtiopäiväaineisto

- Anomusehdotukset 1912-1913

- Asetuskokoelma (AK) 1909, 1915.

- Liitteet 1909-1914

- Valtiopäivät (VP) 1907, Asiakirjat V.

- Valtiopäivät 1908-1917, pöytäkirjat.

\section{Tutkimuskirjallisuus}

Aalto, A., Oras vuosina 1890-1902. Teoksessa Jyväskylän lyseon satavuotishistoria 1858-1958. Toim. Oksala, Päiviö. Jyväskylä 1958.

Aaltonen, Olavi, Wuolijoki, Wäinö, Maatalous- ja finanssiasioiden erikoistuntija. Teoksessa Tiennäyttäjät 3. Suomen työväenliikkeen merkkimiehiä Ursinista Tanneriin. Toim. Soikkanen, Hannu. Rauma 1968.

Afanasjeva, Aleksandra, Materiaalia Edvard Gyllingin viimeisistä elinkuukausista. Teoksessa Edvard Gylling 1881-1991. Ikaalinen 1991.

Ahtiainen, Pekka, Kulttuuri, yhteisö, yksilö, Gunnar Suolahti historiantutkijana. Historiallisia tutkimuksia 162. Vammala 1991.

Ahtiainen, Pekka - Tervonen, Jukka, Menneisyyden tutkijat ja metodien vartijat. Matka suomalaiseen historiankirjoitukseen. Helsinki 1996.

Ala-Kapee Pirjo - Valkonen, Marjaana, Yhdessä elämä turvalliseksi 1. SAK:laisen ammattiyhdistysliikkeen kehitys vuoteen 1930. Helsinki 1982.

Alanen, Aulis J., Hannes Gebhard, Helsinki 1964. 
Alapuro, Risto, Marxilaisesta yhteiskuntatutkimuksesta Suomessa vuosisadan alkupuolella. Tiede ja edistys 2/1977.

Alapuro, Risto, Vallankumous, Historiallinen Aikakauskirja 2/1993.

Alapuro, Risto - Alestalo, Matti - Eskola, Antti - Toiviainen, Seppo, Marxilainen tutkimus. Teoksessa Suomalaisen sosiologian juuret. Toim. Alapuro, Risto et al. Porvoo 1973.

Alapuro, Risto - Alestalo, Matti, Konkreettinen sosiaalitutkimus. Teoksessa Suomalaisen sosiologian historia. Toim. Alapuro, Risto et al. Juva 1992.

Alapuro, Risto - Stenius, Heikki, Kansanliikkeet loivat kansakunnan. Teoksessa Kansa liikkeessä, Toim. Alapuro, Risto et al. Vaasa 1987.

Allardt, Erik, The History of the Social Sciences in Finland 1828-1918. Sociatas Sciantiarum Fennica. Ekenäs 1997.

Autio, Veli-Matti, Roudan aika. Savo-Karjalaisen osakunnan historia III, 1888-1905. Porvoo 1997.

Borg, Olavi, Suomen puolueideologiat. Periaateohjelmien sisältöanalyyttinen vertailu sekä katsaus niiden historialliseen taustaan ja syntyprosessiin. 2. painos. Helsinki 1965 (B).

Caine, Barbara, Biography and history. Theory and history -series. New York 2010.

Ehrnrooth, Jari, Tuottaako uusi näkökulma "uutta historiaa" - esimerkkinä Foucaultin diskurssianalyysin sovellutus oppihistoriaan. Historiallinen Arkisto 93. Toim. Enden, Rauno. Helsinki 1989.

Ehrnrooth Jari, Sanan vallassa, vihan voimalla. Sosialistiset vallankumousopit ja niiden vaikutus Suomen työväenliikkeessä 1905-1914. Historiallisia Tutkimuksia 167. Helsinki 1992.

Ernrooth, Jari, Kapina. Historiallinen Aikakauskirja 2/1993.

Eräsaari, Risto, Konkreettisen sosiaalitutkimuksen syntymekanismit. Teoksessa Edvard Gylling - työväenliikkeen tiedemies. Helsinki 1983.

Eräsaari, Risto, Saksan historiallinen koulukunta. Teoksessa Talous ja yhteiskuntateoria 1. Vanhan maailman talous ja suuri murros. Toim. Heiskala, Risto - Virtanen, Akseli. Helsinki 2011.

Eräsaari, Risto - Rahkonen, Keijo, Johdanto. Teoksessa Työväenkysymyksestä sosiaalipolitiikkaan, Tapiola 1975.

Eskola, Antti - Toiviainen, Seppo - Alestalo, Matti - Alapuro, Risto, Marxilainen tutkimus. Teoksessa Suomalaisen sosiologian juuret. Toim. Alapuro, Risto et al. Porvoo 1973. 
Eskola, Jari - Suoranta, Juha, Johdatus laadulliseen tutkimukseen. Jyväskylä 1998.

Eskola, Seikko, Sosiaalipolitiikka Suomalaisen Puolueen ohjelmassa vuonna 1906. Studia Historica Jyväskyläensiä I. Jyväskylä 1962.

Forsberg, Henrik, Nälkäkuolema kansallishyveenä? Historiallinen Aikakauskirja 3/2011.

Foucault, Michel, The Archealogy of Knowledge. Bristol 1989 (alkuteos L, Archélogie du savoir 1969).

Foucault, Michel, The Order of Things. An Archeology of the Human Sciences. Bristol 1986 (alkuteos Le Mots et les Choses 1966).

Gillespie, Neal C., Charles Darwin and the Problem of Creation. Chicago 1979.

Grimmer-Solem, Erik - Romani, Roberto, The historical school 18701900: a crossnational reassessment. History of Euroapean ideas, Vol 24, Numbers 4-5/1988.

Gronow, Jukka, On the Formation of Marxism. Karl Kautsky, s Theory of Capitalism, the Marxism of the Second International and Karl Marx,s Critique of Political Economy. Commentationes Scientiarum Socialium 33. Helsinki 1986.

Haapala, Pertti, Muotia vai ei? Suomalaisen sosiaalihistorian muuttuvat näkökulmat. Teoksessa Yksilö ja yhteiskunnan muutos. Viljo Rasilan 60 -vuotis juhlakirja. Toim. Kiuasmaa, Kyösti et al., Acta Universitatis Tampereansis, ser A, vol 202. Tampere 1986.

Haapala, Pertti, Luokkasota, Historiallinen Aikakauskirja 2/1993.

Haapala, Pertti, Kun yhteiskunta hajosi. Suomi 1914-1920. Helsinki 1995.

Haapala, Pertti, Väinö Linnan historiasota. Historiallinen Aikakauskirja $1 / 2001$.

Haatanen, Pekka, Sosiaalihistoria. Teoksessa Suomalaisen sosiologian historia. Toim. Alapuro, Risto et al. Juva 1992.

Haavikko, Paavo, Nuijasota, sisällissodan vuodet 1596-1599. Juva 1996.

Hakalehto, Ilkka, Maalaisliitto-Keskustapuolueen historia 1. Maalaisliitto autonomian aikana 1906-1917. Helsinki 1986.

Halila, Aimo, Väinö Voionmaa. Helsinki 1969.

Harjula, Minna, Kelvoton vaalikansalaiseksi. Historiallinen Aikakauskirja 4/2006. 
Heikkilä, Jouko, Kansallista luokkapolitiikkaa. Sosialidemokraatit ja Suomen autonomian puolustus 1905-1017. Historiallisia tutkimuksia 168. Helsinki 1993.

Heikkinen, Sakari - Mauranen, Tapani, Edvard Gylling. Tiede ja edistys 4/1981.

Heikkinen, Sakari - Mauranen, Tapani, Edvard Gylling suomalaisen yhteiskunnan tutkijana. Teoksessa Edvard Gylling - työväenliikkeen tiedemies. Toim. Heikkinen, Sakari - Mauranen, Tapani, Helsinki 1983 (A).

Heikkinen, Sakari - Mauranen, Tapani, Edvard Gyllingin kirjallinen tuotanto 1904-1937. Teoksessa Edvard Gylling - työväenliikkeen tiedemies. Toim. Heikkinen, Sakari - Mauranen, Tapani. Helsinki 1983 (B).

Heikkinen, Sakari - Mauranen, Tapani, Edvard Gylling, yhteiskuntatiede ja historia. Teoksessa Patriotismi, historia ja sosiaalireformismi. Helsingin yliopiston historian laitoksen julkaisuja 2. Toim. Pulkkinen, Tuija. Helsinki 1985.

Hentilä, Marjaliisa. Sovittelija. Matti Paasivuori 1866-1937. Työväen historian ja perinteen tutkimuksen seura. Helsinki 2013.

Hentschel, Volker, Produktion, Produktivität. Teoksessa Geschichtliche Grundbegriffe. Historische Lexicon zur politisch-sozialen Spreche in Deutschland. Herausgegeben von Otto Brunner, Verner Conze, Reinhart Koselleck. Band 5. Stuttgart 1984.

Hietaniemi, Tapani, Mistä feodalismiproblematiikka sai alkunsa? Teoksessa Feodalismi. Toim. Hietaniemi, Tapani et al. Tampere 1997.

Hietaniemi, Tapani, Missä diskurssissa nykyiset feodalismikeskustelut liikkuvat? Teoksessa Feodalismi. Toim. Hietaniemi, Tapani et al. Tampere 1997.

Hietaniemi, Tapani, Max Weber ja Euroopan erityistie. Vertailevia sivilisaatiohistoriallisia tutkielmia. Tutkijaliiton julkaisu 90. Helsinki 1998.

Hilson, Mary, Transnational networks in the development of the co-operative movement in the early twentieth century: Finland in the northern context. Teoksessa Hilson, Mary, Markkola, Pirjo and Östman, Ann-Catrin, Co-operatives and the Social Question. The co-operative movement in northern and eastern Europe (1880-1950). Scandinavia and the Baltic transnational and international challenges. Ed. Lavery, Jason. Cardiff 2012. 
Hobsbawn, Eric. How to chance the world. Tales of Marx and Marxism. London 2012.

Hodgson, John H., Otto Wille Kuusinen. Poliittinen elämäkerta. Helsinki 1974.

Huhtala, Liisi, Kuu torpparin aurinko. Torppari-aihe suomalaisessa kaunokirjallisuudessa 1809-1918. Suomalaisen kirjallisuuden seuran toimituksia 371. Savonlinna 1981

Hyrkkänen, Markku, Revisionismin synty - aatehistoriallinen kausaaliongelma. Sosialistinen politiikka 4/1979.

Hyrkkänen, Markku, Aatehistorian mieli. Historiallinen Aikakauskirja 4/1989.

Hyrkkänen, Markku, Reinhart Koselleck - sosiaali- ja käsitehistorioitsija. Historiallinen Aikakauskirja 4/1994.

Hyrkkänen, Markku, Aatehistorian mieli. Jyväskylä 2002.

Hyvönen, Antti, Työväenliikkeen nousu - Suomen torpparien pelastus. Teoksessa Suurlakkovuosi. Toim. Tuominen, Jussi et al., Kuopio 1955.

Häkkinen, Antti, Johan Adolf Kock, elämäkulkuanalyysi ja historia. Historiallinen Aikakauskirja 4/2012.

Hänninen, Sakari, Marxin talous. Teoksessa Talous ja yhteiskuntateoria 1. Vanhan maailman talous ja suuri murros. Toimittanut Heiskala, Risto - Virtanen, Akseli. Helsinki 2011.

Iggers, Georg, G., New Directions in European Historiography. Revised Edition. Middletown 1984.

Immonen, Hannu, Agraaripoliitikko. Teoksessa Polvinen, Tuomo, Heikkilä, Hannu - Immonen, Hannu, J. K. Paasikivi. Valtiomiehen elämäntyö 1, 1870-1918. Juva 1989.

Jalkanen, K. J., Jyväskylän lyseo 1858-1908. Teoksessa Jyväskylän lyseon satavuotishistoria 1858-1958. Toim. Oksala, Päiviö. Jyväskylä 1958.

Jansson, Jan-Magnus. Eduskunta ja toimeenpanovalta. Teoksessa Eduskuntatyö ja yhteiskunta 1907-1963. Suomen kansanedustuslaitoksen historia XII. Toim. Salervo, Olavi et al. Helsinki 1982.

Jokinen, Arja - Juhila, Kirsi - Suoninen, Eero, Johdanto, Teoksessa Diskurssianalyysin aakkoset, Toim. Jokinen, Arja et al.., Tampere 1993.

Jokinen, Arja - Juhila, Kirsi - Suoninen, Eero, Diskursiivinen maailma. Teoreettisen lähtökohdat ja analyyttiset käsitteet. Teoksessa Diskurssianalyysin aakkoset. Toim. Jokinen, Arja et al., Tampere 1993. 
Jussila, Osmo, Nationalismi ja vallankumous venäläis-suomalaisissa suhteissa 1899-1914. Historiallisia tutkimuksia 110. Helsinki 1979.

Jussila, Osmo, Suomalaisuusliike Venäjän paineessa vuosina 1890-1917. Teoksessa Herää Suomi. Suomalaisuusliikkeen historia. Toim. Tommila, Päiviö, Jyväskylä 1989.

Jutikkala, Eino, Suomen talonpojan historia. 2. uudistettu painos. Helsinki 1958.

Jutikkala, Eino. Talonpoika, aatelismies, kruunu. Maapolitiikkaa ja maanomistusoloja Pohjoismaissa 1550-1750. Juva 1983.

Järvinen, Klaus A. J., Edvard Gylling, Älykäs idealisti, jonka kohtalo ajoi sosialismin syöveriin. Teoksessa Edvard Gylling 1881-1991. Ikaalinen 1991.

Kalela, Jorma, "Jatkomenoinen uudistaminen". Politiikka historiassa ja historiantutkimuksessa. Historiallinen Aikakauskirja 3/2005.

Kangaspuro, Markku, Neuvosto-Karjalan taistelu itsehallinnosta. Nationalismi ja suomalaiset punaiset Neuvostoliiton vallankäytössä 1920-1939. Helsinki 2001.

Karonen, Petri, Patruunat ja poliitikot. Yritysjohtajat taloudellisina ja poliittisina toimijoina Suomessa. Historiallisia tutkimuksia 217. Helsinki 2004.

Kerkelä, Heikki, Vanhan maailman peilissä. Modernin yhteiskunnan synty ja pohjoinen aineisto. Tampere 1996.

Keskisarja, Teemu, Viipuri 1918. Helsinki 2013.

Ketola, Eino, Kansalliseen kansanvaltaan : Suomen itsenäisyys, sosiaalidemokraatit ja Venäjän vallankumous 1917. Helsinki 1987.

Kiuasmaa, Kyösti, Oppikoulu 1880-1980. Oppikoulu ja sen opettajat koulujärjestyksestä peruskouluun. Oulu 1982.

Klinge, Matti, Ylioppilaskunnan historia 3. Porvoo 1968.

Korpinen, Pekka, Edvard Gylling - sosialisti ja tiedemies. Työväen taloudellisen tutkimuslaitoksen katsaus 4/1981.

Koskimies, Rafael, Y. S. Yrjö-Koskisen elämä II. Nuijamieheksi luotu. Keuruu 1974.

Koselleck, Reinhart, Futures past. On the Semantics of Historical Time. London 1985 (alkuteos Vergangene Zukunft 1979). 
Koskela, Lasse - Rojola, Lea, Lukijan ABC-kirja. Johdatus kirjallisuuden nykyteorioihin ja kirjallisuudentutkimuksen suuntauksiin. Tietolipas 150. Rauma 1997.

Kovero, Martti, Gylling, Edvard Otto Vilhelm. Teoksessa Kansallinen elämäkerrasto II. Porvoo 1929.

Kujala, Antti, Venäjän hallitus ja Suomen työväenliike 1899-1905, Historiallisia Tutkimuksia 194. Helsinki 1995.

Kuusisto, Seppo, Kansallishenkeen uskoen. Hämäläis-osakunnan historia 1. Helsinki 1978.

Kuusterä, Antti - Tarkka, Jukka. Suomen Pankki 200 vuotta I, Keisarin kassasta keskuspankiksi. Helsinki 2011.

Lacapra, Dominick, Rethinking Intellectual History: Texts, Contexts, Language. London 1983.

Leino-Kaukiainen, Pirkko, Suomalainen Puolue 1905-1918. Teoksessa Leino-Kaukiainen, Pirkko - Uino, Ari, Suomalais-kansallinen Kokoomus. Suomalaisen Puolueen ja Kansallisen Kokoomuspuolueen historia vuoteen 1929. Vammala 1994.

Luther, Georg, Suomen tilastotoimen historia vuoteen 1970. Tilastokeskuksen tutkimuksia 205a. Helsinki 1993.

Lähteenmäki, Maria, Väinö Voionmaa. Puolue- ja geopoliitikko. Historiallisia tutkimuksia 264. Helsinki 2014.

Manninen, Ohto, Vapaussota, Historiallinen Aikakauskirja 2/1993.

Manninen, Juha, J. V. Snellman - Aatteet ja elämä. Teoksessa J. V. Snellman ja nykyaika. Toim. Huovinmaa, Kai. Helsinki 1981.

Markkola, Pirjo, Työläiskodin synty. Tamperelaiset työläisperheet ja yhteiskunnallinen kysymys. 1870-luvulta 1910-luvulle. Historiallisia tutkimuksia 187. Helsinki 1994.

Markkola, Pirjo - Östman, Ann-Catrin. Torparfrågan tillspetsas. Frigörelse, oberoende och arbete 1919 års torparlagstifning ur mansperspektiv. Historisk tidskrift för Finland 1/2012.

Metsämäki, Mikko - Nisula, Petteri. Aktivistit. Suomalaisen kansalaisliikkeiden tarina. Helsinki 2006.

Mikkeli, Heikki, Aatehistoriasta käsitehistoriaan. Teoksessa Historia Nyt. Näkemyksiä suomalaisesta historiantutkimuksesta. Juva 1990.

Morell, Mats, Jordbroket i industrisamhället 1870-1945. Det svenska jordbrukets historia 4. Red. Myrdal, Janken et al. Borås 2001. 
Mylly, Juhani, Vallan syli ja puristus - suomalaisen historiatutkimuksen suhde poliittiseen valtaan. Historiallinen Aikakauskirja 1/1999.

Niskanen, Kirsti, Kvinnopolitiskt engagemang i könsneutral vetenskap - Karin Kocks könsteoretiska analys under 1930-talet. Kvinnovetenskaplig tidskrift 3-4/2001.

Nurmiainen, Jouko - Piippo, Mikko, Suomalainen historiankirjoitus ja feodalismi. Teoksessa Feodalismi. Toim. Hietaniemi, Tapani et al., Tampere 1997.

Nygård, Toivo, Suomalainen äärioikeisto maailmansotien välillä. Ideologiset juuret, järjestöllinen perusta ja toimintamuodot. Studia Historica Jyväskyläensia 25. Jyväskylä 1982.

Paavolainen, Jaakko, Väinö Tanner, senaattori ja rauhantekijä. Elämäkerta, osa 2. Helsinki 1979.

Pakkanen, Martti, Kyläräätälin poika. Teoksessa Nuori Otto Ville Kuusinen 1881-1920. Toim. Salminen, Vesa. Jyväskylä 1970.

Palonen, Kari, Retorinen käänne poliittisen ajattelun tutkimuksessa. Quentin Skinner, retoriikka ja käsitehistoria. Teoksessa Pelkkää retoriikkaa. Tutkimuksen ja politiikan retoriikat. Toim. Palonen, Kari ja Summa, Hilkka. Tampere 1996.

Pekkarinen, Jukka, Kansantaloudellinen Yhdistys ja taloudellinen keskustelu Suomessa. Teoksessa Sata vuotta suomalaista kansantaloustiedettä. Kansantaloudellinen Yhdistys 1884-1984. Toim. Koskenkylä, Heikki et al., Vammala 1984.

Peltonen, Matti, Talolliset ja torpparit. Vuosisadan vaihteen maatalouskysymys Suomessa. Historiallisia Tutkimuksia 164. Helsinki 1992.

Peltonen, Matti, Torpparikysymys. Teoksessa Suomen maatalouden historia 2. Kasvun ja kriisien aika 1870-luvulta 1950-luvulle. Toim. Peltonen, Matti. Helsinki 2004.

Peltonen, Ulla-Maija, Muistaa vai unohtaa? Vuoden 1918 vaikea historia. Historiallinen Aikakauskirja 4/2003.

Pietiäinen Jukka-Pekka, Rudolf Holsti, Lehtimies, tiedemies, poliitikko 1881-1919. Espoo 1986.

Pitkänen, Kari, Väestöntutkimus ja yhteiskunta. Suomalaisen väestöntutkimuksen historia 1700 -luvulta noin vuoteen 1950 . Suomen väestöntutkimuksen historian julkaisuja n:o 11. Helsinki 1988. 
Pollari, Mikko, Vihan ja sovun sosialistit. Teoksessa Kuriton kansa. Poliittinen mielikuvitus vuoden 1905 suurlakon ajan Suomessa. Tallinna 2009.

Polvinen, Tuomo, Valtakunta ja rajamaa. N. I. Bobrikov Suomen kenraalikuvernöörinä 1898-1904. Juva 1985.

Rahikainen, Marjatta, N. R. af Ursin. Aatelismies Suomen työväenliikkeessä. Historiallisia Tutkimuksia 135, Helsinki 1986.

Rasila, Viljo, Suomen torpparikysymys vuoteen 1909. Historiallisia Tutkimuksia LIX. Helsinki 1961.

Rasila, Viljo, Torpparikysymyksen ratkaisuvaihe. Suomen torpparikysymys vuosina 1909-1918. Helsinki 1970.

Rasila, Viljo, Agraarikysymys Suomessa 1800-luvun lopulla ja 1900-luvun alussa. Historiallinen arkisto 87. Helsinki 1986.

Rasila, Viljo, Vuoden 1910 yhteiskunnan kerrostumat. Historiallinen Aikakauskirja 4/1995.

Rautio, Veli-Matti, Die Bernstein-Debatte. Die politisch-ideologischen Strömungen und die Parteiideologie in der Sozialdemokratischen Partei Deutschlands 1898-1903. Studia Historica 47. Helsinki 1994.

Rautkallio, Hannu, Suuri viha, Stalinin suomalaiset uhrit 1930-luvulla. Juva 1995.

Rautio, Veli-Matti, Puolalainen, juutalainen, vallankumouksellinen nainen: Rosa Luxemburg. Historiallinen Aikakauskirja 2/1999.

Relander, O., O. A. Hainari, muistelmia. Kansan valistusseuran toimituksia 175. A-sarja n:o 1., Helsinki 1917.

Renvall, Pentti, Kuninkaanmiehiä ja kapinoitsijoita Vaasa-kauden Suomessa. II painos. Helsinki 1962.

Rommi, Pirkko, Myöntyvyyssuunnan hahmottuminen Yrjö-Koskisen ja Suomalaisen Puolueen toimintalinjaksi. Historiallisia Tutkimuksia 68. Helsinki 1964.

Salervo, Olavi, Eduskunnan toimintaa valaisevat viralliset asiakirjat. Teoksessa Suomen kansanedustuslaitoksen historia X. Toim. Salervo, Olavi et al. Helsinki 1977.

Salkola, Marja-Leena, Työväenkaartin synty ja kehitys punakaartiksi 2. Helsinki 1985.

Salminen, Vesa, Estetiikan opiskelijasta poliitikoksi vuosina 1900-1906. Teoksessa Nuori Otto Ville Kuusinen 1881-1920. Toim. Salminen, Vesa. Jyväskylä 1970. 
Salminen, Vesa, Laillisuuden esitaistelija vai oman edun tavoittelija Kuusinen ja toinen sortokausi. Teoksessa Nuori Otto Ville Kuusinen 1881-1920. Toim. Salminen, Vesa. Jyväskylä 1970.

Salomaa, Erkki, Edvard Gylling. Teoksessa Tiennäyttäjät 2. Toim. Hannu Soikkanen. Rauma 1967.

Salomaa, Erkki, O.W. Kuusinen. Teoksessa Tiennäyttäjät 3, Toim. Soikkanen, Hannu. Rauma 1968.

Santonen, Arvo, Kansainvälinen I. Utopia ja vallankumous - työväenliike vuoteen 1945. Espoo 1988.

Schanz, Hans-Jørgen, Karl Marxin teoria muurin murtumisen jälkeen. Helsinki 1996.

Schieder, Wolfgang, Sozialismus, Teoksessa Geschichtliche Grundbegriffe. Historische Lexicon zur politisch-sozialen Spreche in Deutschland. Herausgegeben von Otto Brunner, Verner Conze, Reinhart Koselleck. Band 5. Stuttgart 1984.

Seitkari, O., Eduskuntalaitoksen uudistus 1906. Teoksessa Suomen kansanedustuslaitoksen historia V. Helsinki 1958.

Sinivaara, Eero, Jyväskylän lyseon opinkäynti vv. 1858-1908. Teoksessa Jyväskylän lyseon satavuotishistoria 1858-1958. Toim. Oksala, Päivö. Jyväskylä 1958.

Sivula, Sinikka, Sulo Wuolijoki. Teoksessa Tiennäyttäjät 3. Suomalaisen työväenliikkeen merkkimiehiä Ursinista Tanneriin. Toim. Soikkanen, Hannu. Rauma 1968.

Soikkanen, Hannu, Sosialismin tulo Suomeen. Porvoo 1961.

Soikkanen, Hannu, Vuoden 1905 tapahtumat ja niiden taustakehitys suomalaisen tutkimuksen näkökulmasta. Historiallinen Aikakauskirja 1966.

Soikkanen, Hannu, Edvard Valpas. Vanhan työväenliikkeen linjanvetäjä. Teoksessa Tiennänäyttäjät 1 . Suomen työväenliikkeen merkkimiehiä Ursinista Tanneriin. Toim. Soikkanen, Hannu. Rauma 1967.

Soikkanen, Hannu, Kohti kansanvaltaa 1, Suomen Sosialidemokraattinen puolue 75 vuotta, vuodet 1899-1937. Vaasa 1975.

Soikkanen, Hannu, Kuinka pitkälle on ymmärrettävä kohdettaan vai onko häntä arvioitava - elämäkertatutkimuksen haasteita. Historiallinen Aikakauskirja 4/1987.

Soininen, Arvo M., Maatalousväestön v.1910 - tilasto ja todellisuus. Historiallinen Aikakauskirja 3/1976. 
Soininen, Arvo M., Maa- ja metsätalous. Suomen taloushistoria 2.Teollistuva Suomi. Helsinki 1982.

Soininen, Arvo M., Torpparilaitos yhteiskunnallisena instituutiona. Historiallinen Aikakauskirja 1/1999.

Sulkunen, Irma, Naisen kutsumus. Miina Sillanpää ja sukupuolten maailmojen erkaneminen. Juva 1989.

Sulkunen, Irma, Mandi Granfelt ja kutsumusten ristiriita. Hämeenlinna 1995.

Suodenjoki, Sami, Kuriton suutari ja kiistämisen rajat. Työväenliikkeen läpimurto hämäläisessä maalaisyhteisössä 1899-1909. Bibliotheca Historica 129. Helsinki 2010.

Suutala, Maria, Luonto ja kansallinen itsetarkoitus. Teoksessa Hyöty, sivistys, kansakunta. Toim. Manninen, Juha - Patoluoto, Ilkka. Oulu 1986.

Takala, Irina, Gyllingin-Rovion juttu. Carelia 9/1991.

Tervonen, Jukka, Historioitsijasta kansantaloustieteilijäksi. Teoksessa Patriotismi, historia ja sosiaalireformismi. Historiallisen laitoksen julkaisuja N:o 2. Toim. Pulkkinen, Tuija. Helsinki 1985.

Tervonen, Jukka, J. R. Danielson-Kalmari, Historiantutkija ja -opettaja. Historiallisia Tutkimuksia 163. Helsinki 1991.

Thompson, Kenneth, Auguste Comte. The Foundation of Sosiology. London 1976.

Tikka, Marko, Mitä tapahtui? Teoksessa Kansa kaikkivaltias. Suurlakko Suomessa 1905. Toim. Haapala, Pertti et al., Jyväskylä 2008.

Tikka, Marko, Kun kansa leikki kuningasta. Suomen suuri lakko 1905. Suomalaisen kirjallisuuden seuran toimituksia 1247. Helsinki 2009.

Tilli, Jouni, Tiloja, linjauksia, retoriikkaa - historiapolitiikan ulottuvuuksia. Historiallinen Aikakauskirja 3/2009.

Tommila, Päiviö, Suomen historiankirjoitus. Tutkimuksen historia. Porvoo 1989.

Tommila, Päiviö. Suuri Adressi. Helsinki 1999.

Torvinen, Taimi, J. R. Danielson-Kalmari Suomen autonomian puolustajana. Porvoo 1965.

Turunen, Ilkka, Ammattiyhdistysutopia. Vuosisadan vaihteen liberalistista yhteiskuntapolitiikkaa. Teoksessa Kansa liikkeessä. Toim. Alapuro, Risto et al., Vaasa 1987. 
Tuominen, Uuno, Autonomian ajan yksikamarinen eduskunta 19071916. Teoksessa Suomen kansanedustuslaitoksen historia V. Helsinki 1958.

Tuomioja, Erkki, K. H. Wiik. Itsenäisyysmies ja internationalisti. Elämäkerta vuoteen 1918. Helsinki 1979.

Töttö, Pertti, Werner Sombart ja kiista kapitalismin hengestä. Jyväskylä 1991.

Uino, Ari, Biografisen tutkimuksen ääriviivoja. Teoksessa Historia nyt. Historiallisen Yhdistyksen julkaisuja 5. Juva 1990.

Upton, Anthony F., Vallankumous Suomessa 1917-1918. 1. osa. Jyväskylä 1980.

Vares, Vesa, Vanhasuomalainen Lauri Ingman ja hänen poliittinen toimintansa. Juva 1996.

Vares, Vesa, Demokratian haasteet 1907-1919,. Teoksessa Kansanvalta koetuksella. Suomen eduskunta 100 vuotta 3. Toim. Majander, Mikko et al. Helsinki 2006.

Vares, Vesa, Suurlakon häviäjät. Teoksessa Kansa kaikkivaltias. Suurlakko Suomessa 1905. Toim. Haapala, Pertti et al. Jyväskylä 2008.

Vihola, Teppo. Leipäviljasta lypsykarjaan. Maatalouden tuotantosuunnan muutos Suomessa 1870-luvulta ensimmäisen maailmansodan vuosiin. Historiallisia tutkimuksia 159. Helsinki 1991.

Vihola, Teppo, Pärjääkö pienviljelys? Teoksessa Suomen maatalouden historia 2. Kasvun ja kriisien aika 1870-luvulta 1950-luvulle. Toim. Peltonen, Matti. Helsinki 2004.

Viikari, Matti, Die Krise der "historischen" Geschichtsschreibung und die Geschichtsmethodologie Karl Lamprechts. Disertationes Humanarum Litterarum 13. Helsinki 1977.

Väisänen, Seppo, Kansalaissota, Historiallinen Aikakauskirja 2/1993.

Walther, Rudolf, Stand, Klasse. Teoksessa Geschichtliche Grundbegriffe. Historische Lexicon zur politisch-sozialen Spreche in Deutschland. Herausgegeben von Otto Brunner, Verner Conze, Reinhart Koselleck. Band 6. Stuttgart 1990.

Ylikangas, Heikki, Nuijasota. Keuruu 1977.

Ylikangas, Heikki, Sisällissota, Historiallinen Aikakauskirja 2/1993.

Ylärakkola, Arvo, Edvard Gylling, Keuruu 1976. 
Zetterberg, Seppo, Kulttuuria ja kumouspuuhia. Helsingin virolaisyhteisö 1900-luvun alussa. Viro 2013.

Östman, Ann-Catrin, Modernisoituva maatalous. 1870-luvulta ensimmäiseen maailmansotaan. Teoksessa Suomen maatalouden historia 2. Kasvun ja kriisien aika 1870-luvulta 1950-luvulle. Toim. Peltonen, Matti. Helsinki 2004.

\section{Muistelmat}

Gummerus, Herman, Jääkärit ja aktivistit. Sotavuosien muistelmia Tukholmasta ja Berliinistä. Porvoo 1928.

Louhikko, E. K., Teimme vallankumousta. Helsinki 1943.

Tanner, Väinö, Nuorukainen etsii sijaansa yhteiskunnassa. Helsinki 1948.

Wiik, Karl H., Kovan kokemuksen opetuksia. Sananen Suomen työväelle. 3.painos. Helsinki 1919.

Wuolijoki, Hella, Yliopistovuodet Helsingissä 1904-1908. Tapiola 1973.

Wuolijoki, Sulo, Torpparivapautus. Helsinki 1939.

Wuolijoki, Sulo, Vaari muistelee. Pori 1954.

\section{Arvostelut ja mielipidekirjoitukset}

Uola, Mikko, Gylling-kronikka, Historiallinen Aikakauskirja 1977.

Uola, Mikko, Se koira älähtää..., Historiallinen Aikakauskirja 1977.

Väisänen, Seppo, Gylling ja vallankumous, Historiallinen Aikakauskirja 1978.

Ylärakkola, Arvo, Gylling-kronikka, Historiallinen Aikakauskirja 1977.

\section{Runokokoelma}

Saarikoski, Pentti, Tanssiinkutsu. Keuruu 1980. 


\section{Kuunnelma}

Kalemaa, Kalevi, Edward Gylling, Karjalan kuningas. Dokumenttikuunnelma vuodelta 1987

\section{Painamattomat opinnäytteet}

Ek, Stefan, Edvard Gylling som samhällsförskare. Pro gradu. Åbo akademie 1994.

Jussila, Petri, Lamprecht-keskustelu Suomessa 1800- ja 1900-lukujen vaihteessa. Pro gradu. Jyväskylän yliopisto 1995.

Kukkonen, Jukka-Matti, E. G. Palmén historioitsijana. Pro gradu. Turun yliopisto 1976.

Reuna, Risto, Sivistyneistön tulo Suomen vanhaan työväenpuolueeseen. Suomen Sosialidemokraattisen puolueen ensimmäinen sivistyneistösukupolvi. Pro gradu. Helsingin yliopisto 1978.

Uimonen, Kirsi, Työväen Kalenteri työväenliikkeen poliittisten ja sivistyksellisten pyrkimysten kuvaajana vuosina 1908-1939. Pro gradu. Jyväskylän yliopisto 1991. 


Edvard Gylling (1881-1938) tunnetaan parhaiten toiminnastaan Karjalan neuvostotasavallan johtajana, joka teloitettiin Stalinin puhdistusten aikana. Tätä ennen Gylling oli Suomen työväenliikkeen merkittävimpiä johtajia, jonka toiminnassa yhdistyi pyrkimys yhteiskunnan taloudelliseen tehokkuuteen ja halu sosiaalisen oikeudenmukaisuuteen.

Petri Jussila tarkastelee väitöskirjassaan Edvard Gyllingin maatalouspoliittista ajattelua ja toimintaa suurlakon ja sisällissodan välisenä aikana. Gylling oli sosialidemokraattisen puolueen maatalouspolitiikan asiantuntija ja linjanvetäjä, joka painotti historiallista taustaa ja tilastotieteellistä analyysiä yhteiskunnallisen uudistustyön perustana. Hänen ajattelussaan marxilainen teoria oli rinnakkain sosiaalipoliittisen intressin kanssa, joskin näiden kahden asian sovittaminen yhteen oli välillä vaikeaa.

Edvard Gylling ajoi väsymättä torpparien ja muiden maanvuokraajien sekä maaseudun työväestön asiaa. Gyllingin johdolla sosialidemokraatit ajoivat suurlakon jälkeen viljelyspakkoa ja vuokraehtojen parantamista, mutta siirtyivät joitakin vuosia myöhemmin kannattamaan torpparien itsenäistymistä. Poliittisten puolueiden välisten suurten erimielisyyksien takia maaseudun kasvavia ristiriitoja ei saatu ratkaistua, mikä osaltaan vei Suomea kohti sisällissotaa. Petri Jussilan väitöskirja tuo lisävalaistusta myös kansallisen tragediamme taustoihin. 